
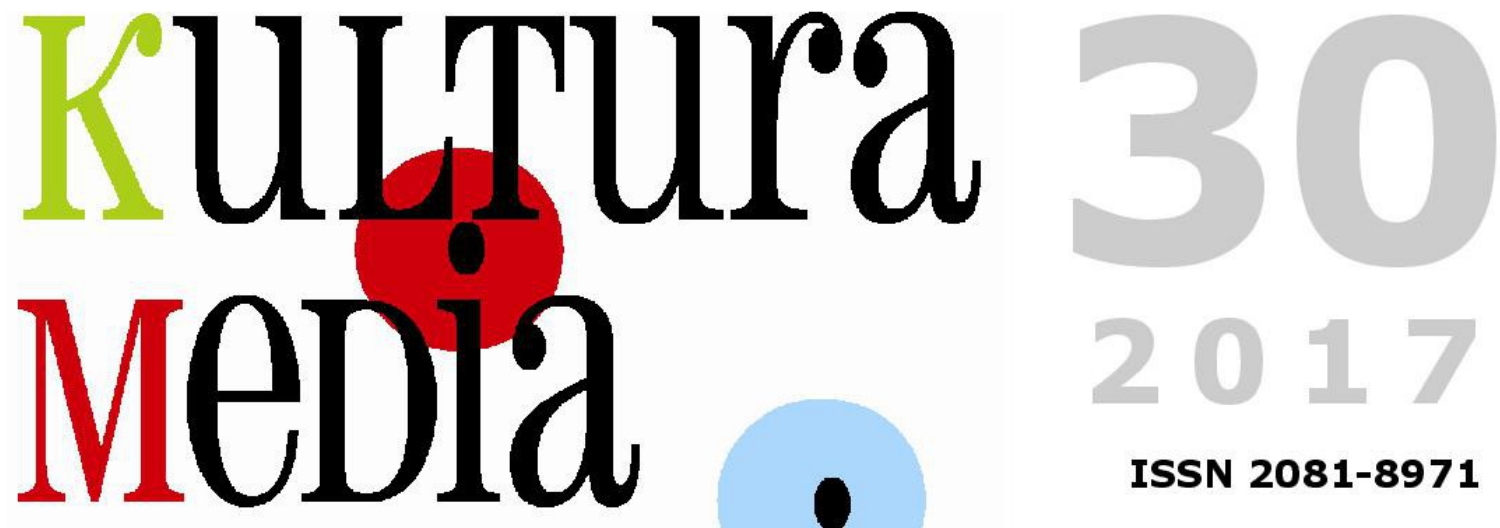

ISSN 2081-8971

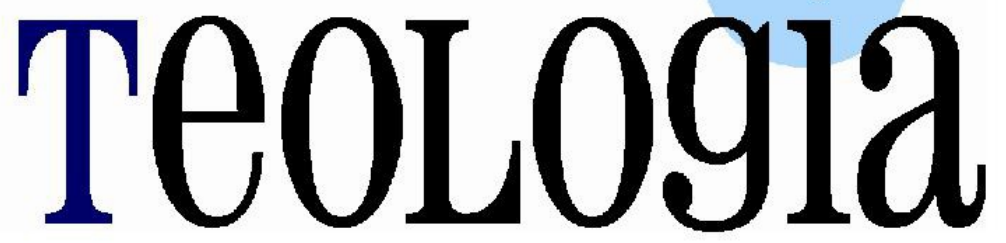

KWARTALNIK

NAUKOWY

WYDZIAEU

TEOLOGICZNEGO

UKSW W WARSZAWIE

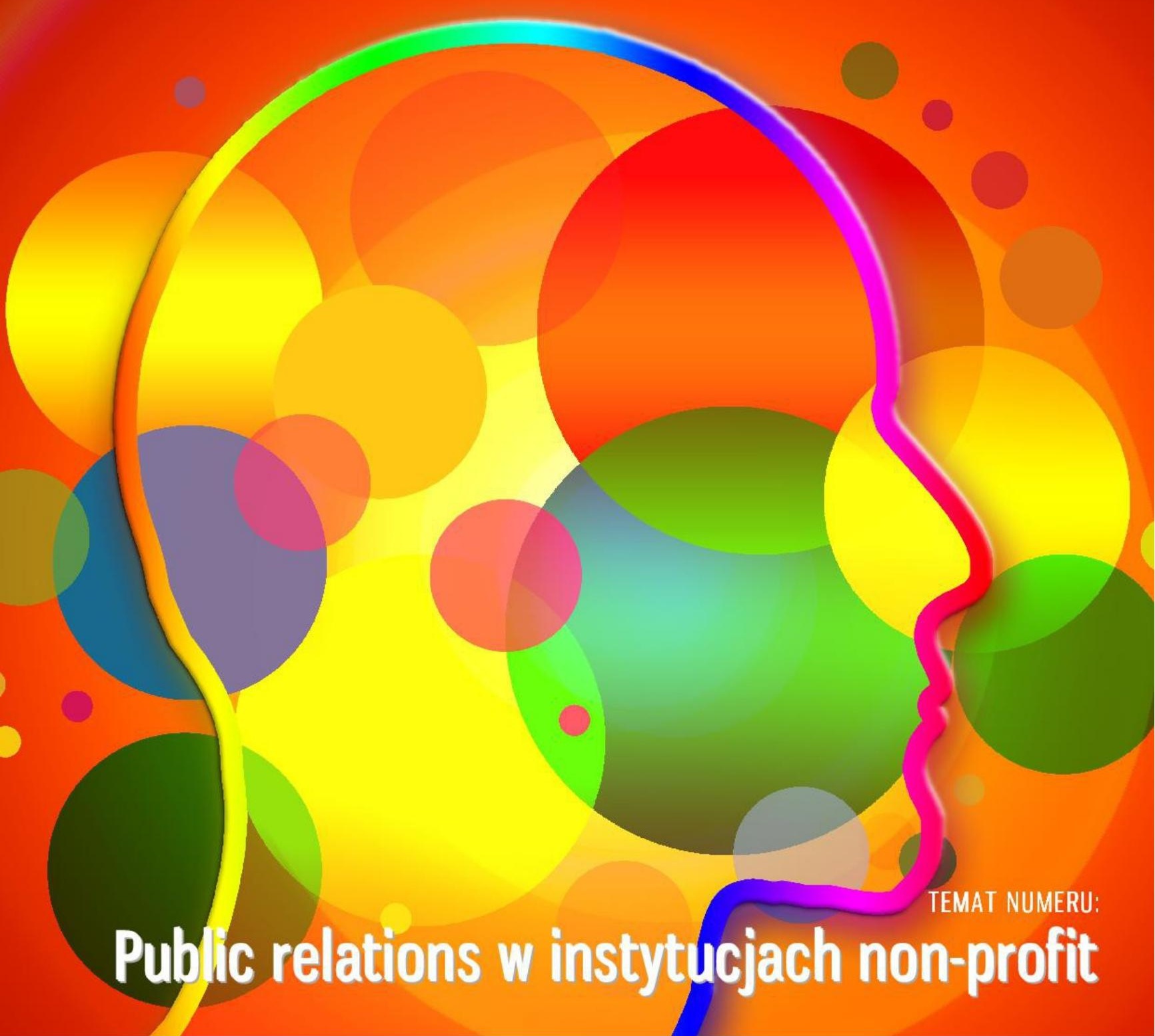




\section{Szanowni Państwo!}

Wiemy, że praca naukowa, choć nieraz żmudna, potrafi być źródłem wielkiej satysfakcji. Jednak jest ona pełna dopiero, gdy można wynikami swej pracy podzielić się ze światem; gdy owe wyniki są szeroko znane i komentowane. Niestety, tradycyjne papierowe czasopisma naukowe mają ograniczony zasięg i znikomą liczbę egzemplarzy. Ponadto na publikację trzeba czekać nawet kilkanaście miesięcy, co bywa powodem uzasadnionej frustracji.

Istnieje jednak proste rozwiązanie tego problemu!

Kwartalnik internetowy „Kultura-Media-Teologia” jest recenzowanym pismem naukowym, powołanym w styczniu 2010 r. i wydawanym online od czerwca 2010 r. pod adresem www.kmt.uksw.edu.pl przez Wydział Teologiczny UKSW w Warszawie. Artykuły są zamieszczane na stronie www i w postaci pliku pdf, co znacznie ułatwia cytowanie, umożliwiając podawanie numerów stron. Natomiast publikacja winternecie oznacza szersze dotarcie do odbiorców, a przez to wzrost cytowalności. Skraca także niewymownie czas oczekiwania na publikację, który w naszym czasopiśmie może wynieść nawet mniej niż 3 miesiące, co $\mathrm{w}$ wypadku czasopism naukowych jest tempem iście ekspresowym!

Ponadto artykuły opublikowane w KMT są szybko i bezproblemowo indeksowane w bazie Google Scholar Citations. Artykuły są również indeksowane w bazie Bazhum, ERIH Plus oraz IC Journals Master List (Index Copernicus).

Wszystkie artykuły publikowane w kwartalniku są recenzowane. Recenzja jest obustronnie anonimowa. Recenzenci są wybierani przez redakcję, są nimi zarówno członkowie Rady Naukowej, jak i osoby spoza niej. Recenzenci krajowi są wybitnymi ekspertami w swoich dziedzinach i mają minimum stopień naukowy doktora i znaczący dorobek w dziedzinie, do której należy recenzowany artykuł. Aby wykluczyć dowolność recenzji, dokonuje się ona w oparciu o przygotowany przez redakcję, standardowy dla wszystkich recenzji, szablon.

Kwartalnik „Kultura-Media-Teologia” spełnia wszelkie wymogi stawiane pismom naukowym. Pismo zostało umieszczone na ogłoszonej w grudniu 2015 r. liście czasopism punktowanych. Znalazło się na liście B, zaś za publikację na łamach KMT w latach 2013-2016 przyznano 8 punktów.

Nasze atuty to:

- szeroki zakres dziedzin;

- wysoka punktacja;

- szybkość publikacji;

- dopracowana szata graficzna;

- staranna redakcja;

- rozpowszechnienie artykułów i szansa na dużą cytowalność; 


\section{KuLTura \\ Media \\ TeoLogia}

NUMER 30/2017

Public relations

w instytucjach non-profit 


\section{кuLTura- мeDia- TeoLogia}

KWARTALNIK NAUKOWY WYDZIAŁU TEOLOGICZNEGO UKSW W WARSZAWIE

ISSN 2081-8971

\section{WYDAWCA:}

REDAKCJA:
Wydział Teologiczny Uniwersytetu Kardynała Stefana

Wyszyńskiego w Warszawie, ul. Dewajtis 5, 01-815 Warszawa

dr hab. Katarzyna Flader (redaktor naczelna)

dr hab. Monika Przybysz, prof. UKSW (zastępca red. nacz.)

dr Marta Jarosz (sekretarz redakcji)

ks. dr hab. Andrzej Adamski, prof. WSIiZ

dr Marek Robak

dr Dagmara Jaszewska

ks. dr hab. Dariusz Pater

dr Małgorzata Laskowska

Rada naukowa:

ks. prof. dr hab. Stanisław Dziekoński (UKSW)

ks. prof. dr hab. Witold Kawecki (UKSW)

ks. prof. dr hab. Henryk Seweryniak (UKSW)

prof. dr hab. Jan Stanisław Wojciechowski (UJ)

prof. dr hab. Rafał Habielski (UW)

prof. dr hab. Jerzy Olędzki (UKSW)

prof. dr hab. Anna Zeidler-Janiszewska (SWPS)

prof. dr hab. Karol Klauza (KUL)

prof. dr Michał Masłowski (Université Paris IV - Sorbonne)

Prof. Andrius Vaišnys, Uniwersytet Wileński

Doc. Mgr. Katarína Fichnová, PhD. - Uniwersytet Konstantyna

Filozofa w Nitrze (Słowacja)

Korekta:

Skład:

Logo i okładka:

\section{Adres redakcji:}

Kontakt: dr Marta Jarosz/ dr hab. Monika Przybysz, prof. UKSW z Zespołem

ks. dr hab. Andrzej Adamski, prof. WSIiZ

ks. dr hab. Andrzej Adamski, prof. WSIiZ;

fot. na okładce: pixabay.com

„Kultura-Media-Teologia”, ul. Dewajtis 5, 01-815 Warszawa,

e-mail:kmt.uksw@gmail.com; http://www.kmt.uksw.edu.pl

Redakcja zastrzega sobie prawo skracania i redagowania tekstów oraz zmiany tytułów. Materiałów niezamówionych nie odsyłamy. Wersję pierwotną (referencyjną) wydawanego czasopisma stanowi publikacja online w postaci pliku *.pdf 


\section{SPIS TREŚCI}

PUBLIC RELATIONS W INSTYTUCJACH NON-PROFIT.

Klaudia Cymanow-Sosin

BUDOWANIE WIZERUNKU INSTYTUCJI NIEKOMERCYJNEJ

NA PRZYKŁADZIE UCZELNI KOŚCIELNEJ - WYBRANE NARZĘDZIA

PUBLIC RELATIONS .10

Marta Brzezińska-Waleszczyk

JAK ZWIĘKSZYĆ SKUTECZNOŚĆ ORGANIZACJI NON PROFIT KORZYSTAJĄC

Z SOCIAL MEDIA? CASE STUDY NA PODSTAWIE WYBRANYCH FUNDACJI

KATOLICKICH

Marek Robak

ANALITYKA INTERNETOWA I JEJ POTENCJAŁ W TRZECIM SEKTORZE .54

Karolina Świrska-Czałbowska

OBRAZ POLSKI I POLAKÓW W EUROPEJSKIM DYSKURSIE PUBLICZNYM.

ANALIZA WYNIKÓW BADAŃ OPINII PUBLICZNEJ I ARTYKUŁÓW Z PRASY

ZACHODNIEJ W LATACH 2004 - 2017.

Krzysztof Wasilewski

INTERNETOWA AKTYWNOŚĆ AMERYKAŃSKIEGO RUCHU ALTERNATYWNEJ

PRAWICY I JEJ WPŁYW NA RADYKALIZACJĘ DEBATY IMIGRACYJNEJ

W STANACH ZJEDNOCZONYCH.

Danuta Kalinowska

PUBLIC RELATIONS W KSZTAŁTOWANIU WIZERUNKU POLSKIEGO

PUBLICZNEGO SZKOLNICTWA NA POZIOMIE SZKÓŁ ŚREDNICH

I GIMNAZJÓW. 123

OBLICZA MEDIÓW I KOMUNIKACJI.

Karolina Polińska

DZIENNIKARSTWO ŚLEDCZE W PRZESTRZENI LOKALNEJ.

ANALIZA PRASOZNAWCZA PUBLIKACJI „DZIENNIKA ZACHODNIEGO”

Z 2015 ROKU.

Tomasz Knecht

MILLENIALSI I ICH „TELE-WIZJE”.

GENEZA I KONSTRUKCJA PROGRAMU BADAWCZEGO.

DIALOG RELIGII I KULTURY.

Joanna Pyszna

POWSTANIE WARSZAWSKIE OCZAMI SIÓSTR ZMARTWYCHWSTANEK

- OBRONA „TWIERDZY ZMARTWYCHWSTANEK”.

Małgorzata Kunicka

TOMISTYCZNO-FENOMENOLOGICZNA KONCEPCJA PERSONALIZMU KAROLA

WOJTYŁY WOBEC KRYZYSU WARTOŚCI I WSPÓŁCZESNYCH POTRZEB

EDUKACYJNYCH.

Jacek Śliwak, Beata Zarzycka, Dominika Ziółkowska, Urszula Piaszczak

RELIGIJNOŚĆ A KOMUNIKACJA W MAŁŻEŃSTWIE. 

TEMAT NUMERU:
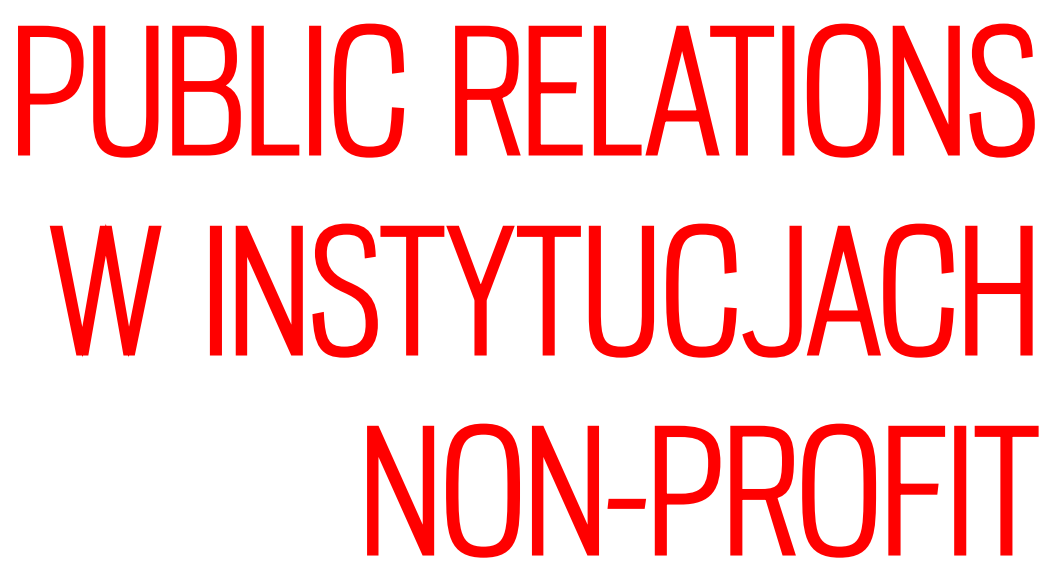

кuLтura- мeDia- теоLogia 30/2017 

кuLTura- мeDia- TeoLogia

ISSN 2081-8971

2017 nr 30, s. 9-29.

Klaudia Cymanow-Sosin,

Instytut Dziennikarstwa i Komunikacji Społecznej UPJP2 w Krakowie

\title{
Budowanie wizerunku instytucji niekomercyjnej na przykładzie uczelni kościelnej - wybrane narzędzia public relations
}

\author{
Creation of the image a non-profit institution on the example of a church university \\ - selected public relations tools
}

\begin{abstract}
STRESZCZENIE:
W ARTYKULE ZOSTAŁY PRZEDSTAWIONE WYNIKI BADAŃ, KTÓRE DOTYCZYŁY OCENY CZTERECH PODSTAWOWYCH

TYPÓW WIZERUNKU, NA PRZYKŁADZIE INSTYTUCJI NAUKOWEJ, JAKA JEST UNIWERSYTET PAPIESKI JANA PaWŁa II W KRAKOWIE. CELEM NADRZĘDNYM BYŁO POSTAWIENIE DIAGNOZY NA TEMAT OCENY BIEŻĄCEGO WIZERUNKU UCZELNI, A TAKŻE UZYSKANIE SZCZEGÓŁOWYCH OPINII O NARZĘDZIACH, JAKIE ZDANIEM RESPONDENTÓW - POWINNY BYĆ
\end{abstract} WYKORZYSTYWANE W BUDOWANIU WŁAŚCIWEJ STRATEGII PROWIZERUNKOWEJ UNIWERSYTETU. HIPOTEZA, IŻ UCZELNIA O CHARAKTERZE KOŚCIELNYM KSZTAETUJE WŁAŚCIWY WIZERUNEK PRZEDE WSZYSTKIM W OPARCIU

O REKOMENDACJĘ I BEZPOŚREDNI KONTAKT Z ODBIORCAMI, ZOSTAŁA ZWERYFIKOWANA TYLKO CZĘŚCIOWO POZYTYWNIE I POSZERZONA O INNE NARZĘDZIA, TJ. IDENTYFIKACJE WIZUALNĄ (CORPORATE IDENTITY) I RELACJE Z MEDIAMI (MEDIA RELATIONS).

W WYNIKU PRZEPROWADZONYCH BADAŃ PRZY UŻYCIU KWESTIONARIUSZA ANKIETOWEGO Z ZASTOSOWANIEM M.

IN. SKALI LIKERTA, OKREŚLONE ZOSTAEY WSKAŹNIKI ZBUDOWANE ZE ŚREDNIEJ ODPOWIEDZI NA PYTANIA, A SKALOWANIE ODPOWIEDZI POZWOLIŁO WYZNACZYĆ PREDYLEKCJE ZAPROPONOWANYCH NARZĘDZI PR I PROPOZYCJE WYKORZYSTANIA NAJBARDZIEJ SKUTECZNYCH METOD. NA PIERWSZYM PLANIE ZNALAZŁA SIĘ KOMUNIKACJA ZAPOŚREDNICZONA MEDIALNIE PRZEDE WSZYSTKIM O OPARCIU O SIEĆ I MEDIA ELEKTRONICZNE. ZDANIEM BADANYCH, RENOMA

\section{ABSTRACT:}

THE PAPER PRESENTS THE RESULTS OF RESEARCH CONCERNING THE EVALUATION OF FOUR BASIC TYPES OF IMAGE, ON THE EXAMPLE OF A SCIENTIFIC INSTITUTION, the University of the Pope John Paul II in Cracow. The MaIn aim WaS TO MaKe a diagnosis OF THE CURRENT IMAGE OF THE UNIVERSITY, AND TO OBTAIN DETAILED OPINIONS ON THE TOOLS THAT RESPONDENTS THINK SHOULD BE USED TO BUILD A PROPER UNIVERSITY VISIBILITY STRATEGY.

THE HYPOTHESIS THAT ECCLESIAL TEACHINGS SHAPE THE RIGHT IMAGE BASED MAINLY ON RECOMMENDATION AND DIRECT CONTACT WITH THE AUDIENCE HAS BEEN PARTIALLY VERIFIED POSITIVELY AND EXTENDED TO OTHER TOOLS: CORPORATE IDENTITY AND MEDIA RELATIONS. AS A RESULT OF THE SURVEY CONDUCTED USING THE QUESTIONNAIRE SURVEY, USING THE LIKERT SCALE, IS BASED ON INDICATORS THAT ARE CONSTRUCTED FROM AVERAGE ANSWERS TO QUESTIONS, AND SCALING OF RESPONSES HAS ALLOWED PREDICTION OF PROPOSED PR TOOLS AND PROPOSALS FOR USING THE MOST EFFECTIVE METHODS. IN THE FOREGROUND THERE WAS MEDIA MEDIATED COMMUNICATION PRIMARILY ON THE BASIS OF THE NETWORK AND ELECTRONIC MEDiA. ACCORDING TO THE RESPONDENTS, THE REPUTATION OF THE UNIVERSITY AND CONCERN FOR ITS REPUTATION AMONG THE YOUNG GENERATION OF MULTIMEDIA USERS CAN MOST EFFECTIVELY BE REALIZED IN SOCIAL MEDIA. THE SIDEEFFECT OF THE RESEARCH IS THE OPINION THAT 


\section{PUBLIC RELATIONS W INSTYTUCJACH NON-PROFIT}

UCZELNI I TROSKA O JEJ REPUTACJE WŚRÓD MŁODEJ GENERACJI UŻYTKOWNIKÓW MULTIMEDIÓW NAJSKUTECZNIEJ MOŻE BYĆ REALIZOWANA W MEDIACH SPOŁECZNOŚCIOWYCH. WNIOSKIEM POBOCZNYM Z PRZEPROWADZONYCH BADAŃ JEST OPINIA, IŻ KOMPATYBILNOŚĆ, SPÓJNOŚĆ I ODPOWIEDNIOŚĆ W OBRĘBIE IDENTYFIKACJI WIZUALNEJ ORAZ W KONTAKTACH ZA POŚREDNICTWEM MEDIÓW SĄ CZYNNIKAMI, KTÓRE - WEDLE RESPONDENTÓW W ZASADNICZY SPOSÓB POMAGAJĄ W BUDOWANIU DOBRYCH RELACJI Z OTOCZENIEM.

SŁOWA KLUCZOWE:

CORPORATE IDENTITY, MEDIA RELATIONS, IDENTYFIKACJA WIZUALNA, PUBLIC RELATIONS
COMPATIBILITY, CONSISTENCY AND RELEVANCE WITHIN VISUAL IDENTIFICATION AND IN MEDIA CONTACTS ARE FACTORS THAT, IN RESPONDENTS' VIEW, HELP IN BUILDING A GOOD RELATIONSHIP WITH THE ENVIRONMENT.

\section{KEYWORDS:}

CORPORATE IDENTITY, MEDIA RELATIONS, VISUAL IDENTIFICATION, PUBLIC RELATIONS

oraz większa świadomość roli i wpływu narzędzi kształtowania wizerunku instytucji o charakterze publicznym oraz szerokorozumiana troska o reputację, czego podstawą są zabiegi public relations w jednostkach niekomercyjnych, były impulsem do podjęcia badań w zakresie oceny różnych typów wizerunku macierzystego uniwersytetu. Celem prowadzonych badań była próba wyselekcjonowania najbardziej optymalnych narzędzi służących do budowy właściwego obrazu uczelni. W zakresie metodyki badań ankiety zostały celowo rozdystrybuowane w gronie studentów przygotowanych do oceny narzędzi medialnych i marketingowych zarówno od strony teoretycznej, jak i praktycznej. Wyselekcjonowana grupa respondentów to nie tylko odbiorcy mediów jako kanału komunikacyjnego pomiędzy instytucją i jej otoczeniem zewnętrznym, ale w znaczącej mierze nadawcy przekazów o charakterze informacyjnym czy promocyjnym. To także nie tylko użytkownicy nowych mediów, w sposób immanentny wpisanych w ich życie, ale w wielu przypadkach kreatorzy i trendsetterzy treści medialnych związanych z budową i podtrzymaniem dobrego wizerunku uczelni.

\section{Struktura badań}

\subsection{Metryczka}

W badaniu wzięli udział słuchacze pierwszego stopnia studiów na kierunku: Dziennikarstwo i Komunikacja Społeczna UPJPII. Grupa została celowo wyselekcjonowana, bowiem zaliczają się do niej tylko ci studenci, którzy mieli lub mają obecnie do czynienia z kursami: Podstawy public relations, Media relations, czy Podstawy promocji, reklamy i marketingu. Sposób doboru próby badawczej określony został w związku ze specyfiką tematu i formułą prowadzonych pomiarów. Nadrzędnym celem było bowiem zdiagnozowanie poziomu oceny wizerunku uczelni, a także uzyskanie opinii na temat narzędzi budowania skutecznej strategii prowizerunkowej uniwersytetu. W ramach próby badawczej została 
także wybrana tzw. „grupa ekspercka”, tj. 25 studentów, którzy, po pierwsze - w toku studiów obrali ścieżkę: Public relations, a po drugie - w ramach prowadzonych zajęć uczestniczą w kursie Logistyka komunikowania wizerunku. Udział liczbowy respondentów ukazuje tab. 1.

Tab. 1. Reprezentacja kobiet i mężczyzn w grupie respondentów.

\begin{tabular}{|l|l|l|l|}
\hline $\begin{array}{l}\text { GRUPA } \\
\text { RESPONDENTów }\end{array}$ & liczba studentów ogółem & grupa podstawowa & "grupa ekspercka” \\
\hline w tym: & 154 & 129 & \\
\hline Kobiety & 114 & 95 & 25 \\
\hline Mężczý́ni & 40 & 34 & 19 \\
\hline
\end{tabular}

Źródło - opracowanie na podstawie badań własnych

Przestawione wyniki wskazują, iż reprezentacja płci w podjętych badaniach odzwierciedla strukturę studentów dziennikarstwa w UPJPII, a proporcje pomiędzy reprezentacją kobiet i mężczyzn w grupie podstawowej oraz eksperckiej w obu badanych grupach są zbliżone.

\subsection{Metoda badań}

Badania pomiaru pośredniego w formie kwestionariusza ankietowego miały charakter anonimowy. Kierując się kategoryzacją opisaną w książce „Marketing. Sposób myślenia i działania”, pod redakcją Józefa Perenca, zaproponowana forma pomiaru zaliczałyby się do badań o charakterze jakościowym, badając „naturę i strukturę upodobań oraz motywacji respondentów (...), dotarcie do nieujawnianych w sposób bezpośredni przyczyn ich zachowania oraz umożliwienie dogłębnego zrozumienia i właściwego zinterpretowania tego zachowania” ${ }^{1}$, ale i ilościowym, określając ,pewne wielkości w celu uzyskania danych statystycznych dotyczących częstotliwości występowania zjawiska i podziału motywacji oraz upodobań" ". Zaproponowane analizy miały funkcję wyjaśniająco-prognostyczną ${ }^{3}$, a zatem celem ich było poszukiwanie zależności przyczynowo-skutkowych badanych zjawisk, a nadto próba przewidywania przyszłych trendów. Wedle alternatywnego wobec wspomnianego tutaj podziału funkcji, należałoby je zaliczyć do badań eksplanacyjnych, tj. badań o charakterze przyczynowo-skutkowym, prowadzonych w celu zweryfikowania konkretnych tez czy przypuszczeń i stworzenia pewnego modelu czy wariantu możliwego do realizacji. ${ }^{4}$ Dotychczasowa

\footnotetext{
${ }^{1}$ J. Perenc (red.), Marketing: Sposób myślenia i działania, Szczecin 2001, s. 56.

${ }^{2}$ Tamże, s. 54.

${ }^{3}$ E. Duliniec, Badania marketingowe w zarządzaniu przedsiębiorstwem, Warszawa 1999, s. 18-20.

${ }^{4}$ Por. L. Garbarski, I. Rutkowski, W. Wrzosek, Marketing. Punkt zwrotny nowoczesnej firmy, Warszawa 2000, s. 212-216.
} 
wiedza na temat kwestii prowizerunkowych zdobyta na podstawie badań empirycznych, prowadzonych w latach wcześniejszych, nakazywała postawienie tezy, iż uczelnia kościelna kształtuje właściwy wizerunek głównie w oparciu o dwa narzędzia z zakresu public relations, tj. kontakt bezpośredni oraz wydawnictwa własne, w tym przede wszystkim - właściwie prowadzoną stronę internetową. Równocześnie, przeprowadzone obecnie badania pilotażowe wskazywały na znaczącą wagę kwestii związanych z relacjami do mediów, czy z mediami (media relations) oraz istotną rolę identyfikacji wizualnej (corporate identity) w aspekcie kształtowania należytego wizerunku tego typu instytucji. Analiza ankiet zebranych w fazie wstępnej projektu pokazała, że w grupie najważniejszych działań w obrębie public relations, których celem jest budowanie pozytywnego wizerunku całej uczelni i poszczególnych kierunków, mieszczą się przede wszystkim: komunikaty prasowe, działalność rzecznika, wywiady z udziałem pracowników uczelni, informacje dla prasy, robocze spotkania z dziennikarzami, czyli wszelkie formy w obrębie media relations. Drugim obszarem, który wspomaga obszar MR są elementy wydawnictw własnych, tj. tematyczne strony internetowe, por tale o profilu informacyjnym czy społecznościowym, a także trafiające do mediów reportaże, materiały audio i video, które wizerunkowo związane są z uniwersytetem. Spośród narzędzi przynależnych do CI, badani zwrócili szczególną uwagę na trzy z nich, tj. znaki (logo) i symbole, wygląd i architekturę obiektów uczelnianych, a także - co dość zaskakujące - prezencję osób, które są wizytówką uczelni. W przypadku ostatniej z wymienionych kwestii, komentarze wskazywały przede wszystkim na takie cechy, jak przestrzeganie etykiety, formę zwracania się do audytorium, a znacznie mniej na ubiór czy cechy fizyczne. Pojęcie to było zatem rozumiane szeroko, jako nie tylko wygląd, ale i sposób zachowania się jakiejś osoby.

\subsection{Wynik badań pilotażowych}

Dobór próby respondentów, jak już to zostało zasygnalizowane, nie miał charakteru przypadkowego, a ściśle celowy. Badania zostały przeprowadzone na próbie ponad 150 osób, z czego $84 \%$ stanowiła tzw. grupa podstawowa, a 16\% tzw. grupa ekspertów. W trakcie prowadzenia badań pilotażowych respondenci zostali poinformowani o formule i zasadach, jakimi należy się kierować podczas udzielania odpowiedzi, a także zostali zaznajomieni z wszelkimi pojęciami, które pojawiły się w przedmiotowej ankiecie. Podczas spotkań poprzedzających badania respondenckie otrzymali wiedzę na temat narzędzi stosowanych $\mathrm{w}$ działaniach prowizerunkowych, technik z zakresu public relations oraz ich funkcji. Wczesna faza projektu badawczego obejmowała badania o charakterze pilotażowym, których celem była weryfikacja odpowiedniości użycia poszczególnych sformułowań, a także sprawdzenie, czy pytania są zbudowane w sposób klarowny dla poszczególnych grup. O ile nie pojawiły się wątpliwości, co do zrozumiałości sensu zaproponowanych pytań, o tyle w jednym z nich - pod wpływem oddolnych sygnałów, płynących z badań pilotażowych - pojawiła się potrzeba wprowadzenia definiowanych kategorii pomocniczych (ujednolicenie formy komunikacji $\mathrm{w}$ obrębie wskazanego narzędzia $\mathrm{z}$ zakresu public relations). Przykład ten ilustruje tabela 2. 
Tab. 2. Fragment ankiety dotyczący wykorzystania media relations i corporate identity $w$ kreowaniu wizerunku uczelni wyższej z zastosowaniem skali od 5=b. wysoka skuteczność do 1=b. niska skuteczność.

\begin{tabular}{|l|l|l|}
\hline Narzędzie public relations & Forma działania & Skala \\
\hline 1.MEDIA RELATIONS & a. konferencje prasowe, wywiady, komentarze, & $\ldots$ \\
(kontakty z mediami) i PU- & b. wysyłka informacji do mediów, & $\ldots$ \\
BLICITY (dbanie o rozgłos) & c. działalność rzecznika prasowego, & $\ldots$ \\
& d. tematyczne strony internetowe jako pomoc dla dziennikarzy, & $\ldots$ \\
& e. portale informacyjne/społecznościowe, & $\ldots$ \\
& f. reportaże, materiały audio i video dla mediów ${ }^{5}$, & $\ldots$ \\
& g. newsletter, mailing, & $\ldots$ \\
& h. aplikacje na telefon, & $\ldots$ \\
& i. grupy dyskusyjne, & $\ldots$ \\
& j. udostępnianie archiwów, & $\ldots$ \\
\hline 2. CORPORATE & k. monitoring mediów. & $\ldots$ \\
IDENTITY (CI), & a. znaki (logo), symbole, nazewnictwo, & $\ldots$ \\
tj. zabiegi zmierzające do & b. wygląd (architektura), & $\ldots$ \\
jednolitego postrzegania & c. rekwizyty, & $\ldots$ \\
tożsamości i osobowości & d. prezencja osób, & $\ldots$ \\
przezjej otoczenie & e. wydarzenia religijne, & $\ldots$ \\
& f. eventy edukacyjne, & $\ldots$ \\
& g. imprezy charytatywne, & $\ldots$ \\
& h. wystawy i ekspozycje, & $\ldots$ \\
& i. stoiska i targi. & $\ldots$ \\
& & $\ldots$ \\
\hline
\end{tabular}

Źródło - opracowanie na podstawie badań własnych.

Pilotaż zweryfikował materiał do badań pod kątem jego późniejszej użyteczności w trakcie wyciągania wniosków badawczych. Pozwolił także na wprowadzenie jasnych kryteriów i parametrów, które dały możliwość odpowiedniej oceny pozyskanego materiału. Wstępne badania ankietowe stały się przyczynkiem do wskazania dodatkowej grupy, którą - zgodnie z charakterystyką Agnieszki Smalec „według charakteru zbiorowości respondentów ${ }^{6}$ - należałoby określić mianem „badania opinii ekspertów”. Eksperci, to wyselekcjonowana grupa posiadająca szczegółową i specyficzną wiedzę na temat rodzaju wizerunku i jego wpływu na reputację analizowanej jednostki. Wśród nich można było zauważyć, iż tematyka wizerunku wewnętrznego, zewnętrznego, realnego i idealnego ${ }^{7}$ wzbudza szczególne zainteresowanie, stąd wstępny projekt został poszerzony o dodatkowe kwestie związane z tym aspektem public relations.

\footnotetext{
${ }^{5}$ Narzędzia te zostały wprowadzone w bloku MR, ponieważ na kierunku Dziennikarstwo i Komunikacja Społeczna funkcjonują: JP2TV (telewizja uczelniana), Radio Bonus (rozgłośnia UPJPII) czy oficjalny fanpage Instytutu Dziennikarstwa i Komunikacji Społecznej UPJPII, a tworzone tam materiały są wykorzystywane w obszarze MR.

${ }^{6}$ A. Smalec, Badania marketingowe, w: Marketing. Sposób myślenia i działania..., dz. cyt., s. 60.

${ }^{7}$ M. Daszkiewicz, S. Wrona, Kreowanie marki korporacyjnej, Warszawa 2014, s. 55.
} 


\subsection{Konstrukcja pytań i sposób przeprowadzenia ankiety}

Ankieta zawierała zarówno pytania otwarte, które zostały opracowane w celu otrzymania swobodnych - tj. formułowanych w sposób zupełnie dowolny - odpowiedzi respondenta. Jako jedyne nie były one zatem skalowane. Pojawiały się też pytania półotwarte i zamknięte - najczęściej z kafeterią. Respondenci mieli do czynienia z kafeterią dysjunktywną (np. przy ocenie stopnia prestiżu uczelni). W ankiecie nie pojawiła się kafeteria koniunktywna, ale badani mieli możliwość dokonywania wyborów ze skali odpowiedzi (tylko jeden wariant odpowiedzi, np. w skali 1-5). Był to jednoznaczny zbiór alternatyw ułożonych w pięciopunktowej skali, gdzie 1 oznaczał całkowite odrzucenie, zaś 5 miało znaczenie kluczowe. Pomiar ten był stosowany w celu stwierdzenia stopnia natężenia i ocen respondentów. Mieli oni także możliwość udzielania odpowiedzi na pytania dotyczące postaw i opinii, badających wyobrażenia studentów co do potrzeby wprowadzenia poszczególnych narzędzi PR, w celu budowania pozytywnego wizerunku uczelni, rozumianego za E. R. Grayem i J. M. Balmerem jako „obraz tworzony bezpośrednio w umysłach odbiorców" ${ }^{8}$.

Po przeprowadzeniu badań pilotażowych, ankieta została dodatkowo zweryfikowana o pytania klasyfikacyjne, w celu uwypuklenia różnic pomiędzy badanymi grupami. Określenia, jakimi poszczególne grupy respondentów posługiwały się, odpowiadając na wskazane pytania, pozwoliły na sfomułowanie wniosków końcowych. Szczególnie znaczące było to w badaniu wpływu narzędzi PR, gdzie zastosowana została skala Likerta. Na jej podstawie określone zostały wskaźniki zbudowane ze średniej odpowiedzi na pytania i podane następnie $\mathrm{w}$ formie liczbowej lub procentowej. Wprowadzenie skalowania pozwoliło także wyznaczyć predylekcje (szczególnie mocne wskazania ${ }^{9}$ ) wśród zaproponowanych narzędzi i przedstawić na tej podstawie konstruktywne propozycje związane z wykorzystaniem najbardziej adekwatnych narzędzi PR w odniesieniu do postawionego problemu badawczego.

\subsection{Cel badań}

Analiza skuteczności oddziaływania i efektywności działań PR, w tym przede wszystkim wizerunkowych, polega (jak twierdzą Marianna Strzyżewska i Małgorzata Rószkiewicz, autorki „Analiz marketingowych”) na szacowaniu danych w dwóch obszarach. Pierwszy z nich, to opisanie - pod względem intensywności i jakości - obecnych stosunków jednostki (instytucji, przedsiębiorstwa etc.) ze środowiskiem zewnętrznym, a drugi, to „działania w zakresie kształtowania dobrych stosunków z otoczeniem” "10, czyli uzyskanie odpowiedzi na pytanie: jakie działania funkcjonują obecnie, a jakie mogą być podejmowane w celu zintensyfikowania relacji i utrzymania lub zbudowania pozytywnego charakteru tych stosunków? Oczywiście, jak podkreśla Philip Kotler, prezentując tzw.

\footnotetext{
${ }^{8}$ E. E. Gray, J. Balmer, Managing corporate image and corporate reputation, “Long Range Planning” nr 31 (5), 1998, s. 695.

${ }^{9}$ G. Gamst, L. S. Meyers, A. J. Guarino, Analysis of Variance Designs. A Conceptual and Computational Approach with SPSS and SAS, Cambridge 2008, s. 10.

${ }^{10}$ M. Strzyżewska, M. Rószkiewicz, Analizy marketingowe, Warszawa 2002, s. 237.
} 
„próbę szacunku wpływu PR” ${ }^{11}$, wkład sfery wizerunkowej jest zawsze szacowany, tj. dokładny (mierzalny) pomiar oddziaływania public relations jest w rzeczywistości niewykonalny. Dopiero niedostatki w obszarze wizerunkowym, jakie w dalszej perspektywie rzutują na niższą ocenę instytucji, mogą być rzeczywistym wskaźnikiem wpływu narzędzi PR na organizację. Zasadą powinno być jednak niedoprowadzanie do tego momentu, który w literaturze przedmiotu jest określany jako sytuacja kryzysowa. ${ }^{12}$

\section{Przedmiot badań}

Badania dotyczyły wizerunku uczelni, która jest dość nietypowa na arenie krakowskich i szerzej - ogólnopolskich szkół wyższych. Najczęściej spotykany podział uczelni, jeśli chodzi o badania wizerunku szkół wyższych dotyczy bowiem tego, czy są to jednostki publiczne, czy też prywatne, które w sposobie funkcjonowania pod względem promocji, public relations i marketingu podlegają prawom właściwym przedsiębiorstwom. Pierwszy w Europie Środkowo-Wschodniej i trzeci (poza Rzymem i Salamanką) uniwersytet papieski, należący do Międzynarodowej Federacji Uniwersytetów Katolickich (FIUC), stanowi w puli krakowskich szkół wyższych jednostkę wyjątkową, ponieważ jest uczelnią kościelną, finansowaną na zasadach uczelni publicznych. Uniwersytet Papieski Jana Pawła II w Krakowie wywodzi się z najstarszej w naszym kraju, mającej przeszło sześciusetletnią tradycję, uczelni - Uniwersytetu Jagiellońskiego. Studium Generale, zatwierdzone przez papieża Urbana V w maju 1364 roku za czasów Kazimierza Wielkiego nie posiadało jednak wydziału teologii. Dopiero w 1397 roku na prośbę królowej Jadwigi i jej małżonka Władysława Jagiełły papież Bonifacy IX wydał bullę „Eximiae devotionis affectus”, erygującą Wydział Teologii w Krakowie. Data ta rozpoczyna 600-letnią działalność fakultetu. Wydział Teologiczny przez kilka stuleci był najważniejszym w krakowskiej uczelni, a w okresie dawnej Rzeczypospolitej rektorzy krakowskiej uczelni wywodzili się przede wszystkim z grona teologów. Mimo represji i strat personalnych w wyniku II wojny światowej, a także decyzji Rady Ministrów, która w 1954 roku jednostronną uchwałą usunęła Wydział Teologiczny z Uniwersytetu Jagiellońskiego, faktyczna i kanoniczna działalność wydziału trwała. W pięć lat później Stolica Apostolska wydała dekret o ustanowieniu władz kościelnych nad wydziałem, a staraniem kardynała Karola Wojtyły w 1974 roku otrzymał on zaszczytny tytuł Papieski. W 1981 roku już jako papież Jan Paweł II powołał Papieską Akademię Teologiczną, a w 2009 roku jego następca Benedykt XVI pragnąc uhonorować pamięć wielkiego Poprzednika, podniósł Akademię do godności Uniwersytetu Papieskiego Jana Pawła II $^{13}$. Przytoczenie tego dłuższego fragmentu opisującego dzieje uniwersytetu wydaje się konieczne, gdyż pryzmat jego wyjątkowej tradycji, a nade wszystko misji, szczególnie dziś stanowi wyróżnik na tle innych uczelni krakowskich i większości polskich. Fakt, skąd wywodzi się dzisiejszy UPJPII jest także bardzo mocną zmienną (największym atutem dla jednych, a znaczną barierą dla innych) w diagnozach dotyczących public relations w aspekcie wizerunkowym, opisywanej uczelni.

\footnotetext{
${ }^{11}$ P. Kotler, Marketing; Warszawa 1994, s. 626.

${ }^{12}$ K. Kubiak (red.), Zarządzanie w sytuacjach kryzysowych niepewności, Warszawa $2012 \mathrm{i}$ in.

${ }^{13}$ Zob. http://www.upjp2.edu.pl/?q=uczelnia/uczelnia/o-nas/historia (dostęp: 11.10.2017 r.).
} 


\section{Ankieta}

\subsection{Decyzja o podjęciu studiów w UPJPII}

Pierwsza część ankiety miała za zadanie zbadać, jak wygląda komunikacja zewnętrza uniwersytetu z kandydatami na studia oraz jakie są ich preferencje co do wyboru związanego z kierunkiem studiów. Pierwsze pytanie zasadniczej części ankiety dotyczyło źródła, z którego jako kandydaci czerpali wiedzę na temat możliwości podjęcia studiów na Uniwersytecie Jana Pawła II w Krakowie.

Tab. 3. Pierwsze źródło wiedzy o uczelni (grupa podstawowa).

\begin{tabular}{|l|l|l|}
\hline Źródło & $\%$ osób & Uwagi dodatkowe \\
\hline Strona www & $46 \%$ & $\begin{array}{l}\text { Strona startowa UPJPII i strona instytutu (IDIKS), portale } \\
\text { o charakterze edukacyjnym }\end{array}$ \\
\hline Kontakty bezpośrednie & $30 \%$ & Osoby aktualnie studiujące na UPJP2 \\
\hline Ulotka & $2 \%$ & Przekazana przez członka rodziny lub w parafii \\
\hline Ulotka znaleziona w innej uczelni & $2 \%$ & $\begin{array}{l}\text { Ulotki z Uniwersytetu Jagiellońskiego (niewielka } \\
\text { odległość) }\end{array}$ \\
\hline $\begin{array}{l}\text { Rekomendacja nauczycieli w szkole } \\
\text { średniej }\end{array}$ & $2 \%$ & W szkołach krakowskich \\
\hline Ogłoszenia kościelne & $10 \%$ & List Rektora UPJPII \\
\hline Dni otwarte & $4 \%$ & $\begin{array}{l}\text { Prezentacja uczelni przez studentów i wykładowców } \\
\text { UPJPII }\end{array}$ \\
\hline Decyzja za radą rodziców & $4 \%$ & Brak własnej wizji przyszłości \\
\hline
\end{tabular}

Źródło - opracowanie na podstawie badań własnych.

Tab. 4. Pierwsze źródło wiedzy o uczelni (grupa ekspercka).

\begin{tabular}{|l|l|l|}
\hline Źródło & $\%$ osób & Uwagi dodatkowe \\
\hline Strona www & $38 \%$ & Strona główna UPJPII \\
\hline Kontakty bezpośrednie & $26 \%$ & $\begin{array}{l}\text { Osoby, które były lub obecnie są związane } \\
\text { z uniwersytetem }\end{array}$ \\
\hline Ulotka przekazana przez bliską osobę & $8 \%$ & Rodzice i rodzeństwo \\
\hline Ulotka znaleziona w innej uczelni & $0 \%$ & \\
\hline $\begin{array}{l}\text { Rekomendacja nauczycieli w szkole } \\
\text { średniej }\end{array}$ & $2 \%$ & Dotyczy województwa małopolskiego \\
\hline Ogłoszenia kościelne & $18 \%$ & List rektora UPJPII, ogłoszenia parafialne \\
\hline Dni otwarte & $0 \%$ & Prezentacja uczelni przez studentów UPJPII \\
\hline Decyzja za radą rodziców & $8 \%$ & Brak własnej wizji przyszłości \\
\hline
\end{tabular}

Źródło - opracowanie na podstawie badań własnych.

Nawet w relacji rok do roku można mówić o coraz silniejszym trendzie, do czerpania informacji o uczelniach i poszczególnych kierunkach ze stron internetowych i portali edukacyjnych, a także tendencję do coraz większej dywersyfikacji źródeł. Oczywiście w wyniku 
przedstawionych badań jest to zbyt krótki horyzont czasowy i ten aspekt domaga się badań w kolejnych próbach. Dodatkowa uwaga dotyczy faktu, że ostateczna decyzja co do podjęcia studiów na określonym kierunku ma charakter wielokryterialny, a pytanie dotyczyło tylko pierwszego źródła wiedzy o uniwersytecie. Drugie pytanie dotyczyło wybranej cechy/właściwości, która w sposób najsilniejszy zdecydowała o wyborze tej właśnie uczelni (tab. 6).

Tab. 5. Odpowiedzi w grupie podstawowej.

\begin{tabular}{|l|l|l|}
\hline Atrybut & \% odp. & Uwagi dodatkowe \\
\hline Katolicki charakter uczelni & $22 \%$ & $\begin{array}{l}\text { Równocześnie aż 19\% wskazało na inne atrybuty, } \\
\text { zaznaczając, że fakt iż jest to uczelnia katolicka } \\
\text { stanowiło częściową barierę przy dokonywaniu decyzji } \\
\text { o podjęciu studiów }\end{array}$ \\
\hline Lokalizacja & $21 \%$ & W centrum miasta \\
\hline Indywidualne podejście do studenta & $18 \%$ & Chęć pomocy ze strony wykładowców \\
\hline $\begin{array}{l}\text { Praktyczne przygotowanie do } \\
\text { zawodu }\end{array}$ & $14 \%$ & Telewizja i radio na uczelni \\
\hline Dobra atmosfera & $11 \%$ & \\
\hline Prestiż,jakim cieszy się uczelnia & $5 \%$ & $\begin{array}{l}\text { Studenci zaznaczali, iż prestiż ten dotyczy głównie } \\
\text { historii i patrona uczelni }\end{array}$ \\
\hline Praktyki w ciekawych redakcjach & $4 \%$ & \\
\hline Późna rekrutacja & $2 \%$ & \\
\hline Inne & $3 \%$ & \\
\hline
\end{tabular}

Źródło - opracowanie na podstawie badań własnych.

Tab. 6. Odpowiedzi w grupie eksperckiej.

\begin{tabular}{|l|l|l|}
\hline Atrybut & \% odp. & Uwagi dodatkowe \\
\hline Dobre opinie o uczelni i jej prestiż & $23 \%$ & $\begin{array}{l}\text { Opinie te związane były przede wszystkim } \\
\text { z czynnikiem ludzkim }\end{array}$ \\
\hline Lokalizacja & $22 \%$ & Szczególnie podkreślana bliskość dworca PKP i PKS \\
\hline Ciekawe sylabusy i plan studiów & $16 \%$ & Ścieżki edukacyjne (gł. public relations i nowe media) \\
\hline Znana kadra wykładowców & $14 \%$ & $\begin{array}{l}\text { Znane nazwiska profesorów i redaktorów np. z mediów } \\
\text { elektronicznych (gł. telewizji) i prasy (dziennikarze } \\
\text { i autorzy książek). }\end{array}$ \\
\hline Katolicki charakter uczelni & $13 \%$ & $\begin{array}{l}\text { Prawie tyle samo osób (10\%) w uwagach stwierdziło, że } \\
\text { katolicki charakter uczelni, był kontrargumentem przy } \\
\text { wyborze świeckiego kierunku na katolickiej uczelni }\end{array}$ \\
\hline $\begin{array}{l}\text { Wyższa renoma, niż uczelni } \\
\text { prywatnych }\end{array}$ & $5 \%$ & \\
\hline $\begin{array}{l}\text { Możliwośćłączenia dwóch } \\
\text { kierunków studiów }\end{array}$ & $4 \%$ & Studia na innej uczelni \\
\hline Inne & $3 \%$ & \\
\hline
\end{tabular}

Źródło - opracowanie na podstawie badań własnych.

Jak wskazują wyniki w poszczególnych grupach kwestia lokalizacji uczelni (w obu grupach na drugim miejscu) oraz dobra opinia o uczelni w grupie eksperckiej (najwięcej wskazań), a także katolicki charakter uczelni (w grupie podstawowej) stanowiły najsilniejszą dominantę co do wyboru studiów. Należy równocześnie zwrócić uwagę na fakt, 
iż studia o charakterze świeckim mają miejsce w uczelni kościelnej. Budzi to szczególne zainteresowanie nawet wtedy, gdy inne czynniki decydują o wyborze tego miejsca studiowania. Ostatnie w tej części ankiety pytanie - mające także charakter pytania filtrującego i uogólniającego - brzmiało: Co najbardziej zachęca, a co może budzić wątpliwości podczas podejmowania decyzji o wyborze studiów w UPJPII z perspektywy osoby studiującej? Tutaj respondenci mogli wymienić więcej niż jedną przyczynę.

Wśród powodów, które mogą zachęcić do podjęcia studiów w UPJPII najczęściej wymieniano: Patrona - Jana Pawła II. Wiązane to było z faktem, że imię pojawia się w nazwie uniwersytetu, co zdaniem respondentów podnosi prestiż jednostki (na fakt ten zwracali uwagę głównie studenci z grupy eksperckiej).

Druga grupa argumentów przemawiająca za studiowaniem w UPJPII, to kwestie lokalizacyjne (pojawiały się następujące stwierdzenia: „świetna lokalizacja”, „,kameralna uczelnia”, „dobry dojazd”) i administracyjne („bardzo dobry kontakt z dziekanatem i sekretariatem podczas rekrutacji”). Odpowiedzi w tej części ankiety ściśle korelują z poprzednim pytaniem, gdzie silną dominantą przy wyborze dokonanym przez respondenta była właśnie kwestia umiejscowienia siedziby uczelni.

Trzecia grupa powodów, to opinie o „bardzo dobrych relacjach student - wykładowca”. Respondenci podkreślali w swoich komentarzach, że prowadzący zajęcia poświęcają czas swoim podopiecznym, np. wspomagając studenckie inicjatywny, projekty naukowe i integracyjne (do których studenci są zapraszani już w trakcie immatrykulacji).

Ostatnia grupa działań zachęcających do studiowania w tym miejscu, to liczne praktyki poza uczelnią, a także innowacje w zakresie zaplecza technicznego. Równocześnie, jako przeciwwaga, pojawiły się wątpliwości (w kolejności od najczęściej wymienianych): „silna dominacja przedmiotów o tematyce teologicznej”, „wysoki poziom trudności przedmiotów teologicznych”, „modlitwa przed zajęciami”, „zajęcia z przedmiotów dziennikarskich prowadzone przez księży”. Dylematy związane z łączeniem na studiach dziennikarskich przedmiotów tzw. „świeckich” $\mathrm{z}$,teologicznymi” pojawiły się łącznie u aż $21 \%$ badanych w grupie podstawowej (i u 14\% w grupie eksperckiej), a tylko jedna osoba miała zdanie odmienne: „Największe wątpliwości może budzić fakt, że studiując tu dziennikarstwo (kierunek świecki) nie wszyscy będą szanować jej (uczelni - przyp. K.C-S.) katolicki charakter i jawne wyznawanie wiary, deklarowanie życia zgodnego z dekalogiem i mówienie o Bogu z odwagą może być wyśmiane przez młodych ludzi”.

Kolejna grupa to wątpliwości związane z kwestiami dotyczącymi organizacji studiów (np.: „opinia, iż w UPJPII sprawdzana jest obecność na wykładach”), poziomu nauczania („,bardzo trudna sesja”) oraz prestiżem uczelni („obawy mogą być spowodowane tym, że nie jest to uczelnia tak znana, jak UJ”).

\subsection{Grupa pytań dotyczących kwestii wizerunkowych a. Wizerunek własny}

W tej części ankiety nastąpił podział na cztery rodzaje wizerunku, według klasyfikacji opisanej przez Magdalenę Daszkiewicz i Sylwię Wronę w książce „Kreowanie marki kor- 
poracyjnej" ${ }^{14}$. Najpierw poddany został analizie wizerunek własny, a więc fakt, jak studenci widzą swoją własną uczelnie.

Pytanie pierwsze dotyczyło oceny uniwersytetu pod kątem jego prestiżu w oczach studiujących. Zdaniem $61 \%$ respondentów z grupy podstawowej ich macierzysty uniwersytet cieszy się średnim prestiżem. Prawie 1/4 badanych określiła prestiż jako niski, a zaledwie 14,5\% jako wysoki. Jak wskazuje tabela, lepiej swoją uczelnię pod kątem prestiżu widzą studenci, którzy specjalizują się w tematyce wizerunkowej. Największa różnica występuje w zakresie oceny uniwersytetu jako instytucji o niskim prestiżu (13,5\% różnicy). Równocześnie, w wypowiedziach tej grupy pojawiały się następujące stwierdzenia: „W miarę poznawania uczelni zacząłem coraz bardziej ją doceniać i stała się dla mnie z czasem bardzo prestiżowa”, „Studiuję na dwóch uczelniach równocześnie i porównując je (tj. UJ i UPJPII) myślę, że są tak samo prestiżowe, chociaż wiem, że studenci, którzy ich nie znają tak nie myślą".

\section{Tab. 7. Wyniki opinii respondentów nt. prestiżu uczelni.}

\begin{tabular}{|l|l|l|l|}
\hline $\begin{array}{l}\text { Prestiż (grupa } \\
\text { podstawowa) }\end{array}$ & Wysoki & Sredni & Niski \\
\hline & $14,5 \%$ & $61 \%$ & $24,5 \%$ \\
\hline $\begin{array}{l}\text { Prestiż (grupa } \\
\text { ekspercka) }\end{array}$ & Wysoki & Średni & Niski \\
\hline & $18 \%$ & $71 \%$ & $11 \%$ \\
\hline
\end{tabular}

Źródło - opracowanie na podstawie badań własnych.

W części dotyczącej wizerunku własnego znalazła się także prośba dotycząca wymienienia trzech określeń (cech), które jako pierwsze kojarzą się z ich uczelnią (pyt. 2). Skojarzenia, które pojawiały się najczęściej, związane były z pięcioma obszarami:

- Obszar 1. Poczucie wspólnoty akademickiej (łącznie u ponad połowy respondentów): kameralny (26\%), otwarty (23\%), uczelnia prostudencka (11\%).

- Obszar 2. Pozycja uniwersytetu: „,wiedza” (31\%), „,nauka” (18\%), „renoma kierunków” (12\%).

- Obszar 3. Religia i wartości: „katolicka” (66\%), „rodzina” (26\%), „konserwatywna” $(11 \%)$.

- Obszar 4. Przestrzeń: „centrum” (22\%), „w sercu Krakowa” (9\%), „w sąsiedztwie Franciszkańskiej 3" (6\%).

- Obszar 5. Czynnik ludzki: Jan Paweł II (83\%), „księża-wykładowcy” (52\%), „doświadczenie prowadzących” (31\%), „habit i sutanna” (8\%), „ksiądz Oko” (5\%).

W przypadku grupy eksperckiej w tych samych obszarach pojawiały się innego typu sformułowania, tj. w obszarze 1. najczęściej powtarzały się takie pojęcia, jak: „inte-

${ }^{14}$ M. Daszkiewicz, S. Wrona S., Kreowanie marki korporacyjnej, dz. cyt., s. 55. 
gracja” (36\%), „współpraca” (21\%), „lojalność” (17\%); w obszarze 2. - „profesjonalizm” (24\%), „rozwój” (22\%), „kultura” (18\%), „praktyczne podejście do zawodu” (14\%); w obszarze 3. - „katolicka” (52\%), „etyka” $(7 \%)$, „prawda i dobro” (5\%); w obszarze 4. - „rynek” (40\%), „zabytkowe mury” (14\%), a obszarze 5. najczęściej powtarzały się skojarzenia personalne: Jan Paweł II (74\%), zaś w dwóch przypadkach były to nazwiska wykładowców: „prawda i dobro - ks. prof. Michał Drożdż”, „doświadczenie prowadzących - prof. Walery Pisarek".

Według wskazań obu grup respondentów najczęściej pojawiającym się skojarzeniem (wymienianym także na miejscu pierwszym) jest postać patrona - Jana Pawła II, a na drugim miejscu przymiotnik „katolicki”. W grupie podstawowej na miejscu trzecim pojawia się pojęcie: „księża-wykładowcy”, a w grupie eksperckiej „współpraca”. Przyjęta w tym miejscu ankiety metoda swobodnych skojarzeń słownych (w badaniach społecznych i marketingowych stosowana najczęściej dla uzyskania szczerych odpowiedzi w grupie specjalistów), ugruntowuje trend możliwy do zaobserwowania we wcześniejszych odpowiedziach. W grupie eksperckiej (słuchacze ostatniego roku studiów pierwszego stopnia) $\mathrm{w}$ dalszym ciągu widzą uczelnię przez pryzmat jej katolickiego charakteru, jednak myślenie stereotypowe (schematy myślowe i klisze, typu: „księża-wykładowcy”, czy „habit i sutanna”) ustępuje skojarzeniom związanym z takimi obszarami, jak: integracja, czy współpraca zarówno w obrębie grup studentów, jak i z kadrą naukowo-dydaktyczną.

Trzecie pytanie w tej grupie dotyczyło oceny systemu identyfikacji wizualnej uniwersytetu (visual identity). Spośród kompleksowej identyfikacji, na którą składają się system wizualny, system dotyczący zachowań (w tym - stylu kontaktów z otoczeniem) oraz systemu przekazu w działaniach promocyjnych, w tej części ankiety respondenci zostali poproszeni o wyrażenie opinii wyłącznie na temat pierwszego z wymienionych aspektów, tj. wspólnej, rozpoznawalnej symboliki logo, elementów graficznych i kolorystyki. Odpowiedzi na pytanie o tej aspekt zostały zamieszczone w tab. 8 .

Tab. 8. Odpowiedź na pytanie o ocenę wybranych symboli (znak graficzny i logotyp) UPJP2.

\begin{tabular}{|l|l|l|l|l|l|}
\hline Stopień & Bardzo dobrze (5) & Dobrze (4) & Średnio (3) & Miernie (2) & Źle (1) \\
\hline $\begin{array}{l}\text { \%wskazań (gru- } \\
\text { pa podstawowa) }\end{array}$ & $78 \%$ & $17 \%$ & $5 \%$ & - & - \\
\hline Stopień & Bardzo dobrze (5) & Dobrze (4) & Średnio (3) & Miernie (2) & Źle (1) \\
\hline $\begin{array}{l}\text { \%wskazań (gru- } \\
\text { pa ekspercka) }\end{array}$ & $82 \%$ & $18 \%$ & - & - & - \\
\hline
\end{tabular}

Źródło - opracowanie na podstawie badań własnych.

W całej ankiecie w tym właśnie punkcie pojawiła się największa zbieżność opinii. Symbole uczeni zostały ocenione zdecydowanie pozytywnie. Znak graficzny i cały logotyp określane były jako elementy kształtujące jednoznacznie korzystny wizerunek uczelni. W przypadku grupy podstawowej 4\% respondentów zwróciło uwagę na fakt, że logo 
UPJPII jest niemalże tożsame z logo Uniwersytetu Jagiellońskiego (badani, w trakcie ankietowania nie mieli dostępu do znaków graficznych uczelni). Z analizy rubryki „dodatkowe uwagi" w dwóch ankietach (margines błędu) można było skonstatować, iż logo i symbole uczelni były mylone z kampanią „Studiuj w sercu Krakowa” i pojawiającą się w niej symboliką czerwonego serca. W grupie eksperckiej logo zostało ocenione jeszcze wyżej (we wszystkich wskazaniach opinia dobra lub bardzo dobra), przy czym studenci specjalizujący się w komunikacji wizerunkowej podkreślali następujące zalety: „kojarzy się z historią”, „symbolika zapadająca w pamięć”, „czytelna symbolika”, „wyróżnia się kolorem i grafiką".

Ostatnie pytanie $w$ tej grupie dotyczyło zmian $w$ wizerunku własnym uczelni i było formułowane następująco: Określ, co uległo zmianie w postrzeganiu uczelni, od kiedy na niej studiujesz?

Analizując odpowiedzi na to pytanie, można wyodrębnić dwie wyraźne grupy problemów. Pierwsza, to zmiany opinii w zakresie religii i wartości. Spośród licznych wypowiedzi w grupie podstawowej najczęściej pojawiały się następujące: „Na wiele zajęć, które miałam do tej pory z osobami duchownymi, tylko dwóch księży rozpoczynało swoje wykłady modlitwą, co mnie zdziwiło, bo słyszałam wcześniej, że tak się dzieje przed każdym wykładem”; „Mniej duchownych, niż myślałem”; „Studenci nie są tacy zaangażowani w Kościół, jak myślałam”; „Myślałem, że wcześniej skończą się przedmioty teologiczne".

Druga grupa zmian opinii dotyczyła poziomu studiów: „Myślałam, że egzaminy będą trudniejsze”; „Kadra jest dobierana w zależności od potrzeb kierunku, a nie jak na innych uczelniach w Krakowie”; „Profesorowie pracują ze studentem indywidualnie”, „Wcale nie robią tu prania mózgu”.

W grupie eksperckiej opinie były mniej kategoryczne i dominowały wypowiedzi dotyczące przede wszystkim poziomu studiów, rozwoju technologicznego oraz wykładowców: „Nie sądziłam, że tak mała uczelnia będzie znana z własnego: radia, telewizji, studia nagrań czy laboratorium nowych mediów”; „Mili wykładowcy okazują się podczas egzaminów bardzo wymagający”; „Zmiana o 180\% - zniknęły wszystkie moje uprzedzenia, co do specyfiki uczelni katolickiej. Studiuje się tutaj, jak na normalnej uczelni”.

Na podstawie wypowiedzi dotyczących wizerunku własnego uczelni można wysnuć wniosek, iż studenci darzą uczelnię w większości średnim prestiżem, doceniają walory integracyjne i edukacyjne (głównie związane z kadrą), bardzo wysoko oceniają symbole graficzne stanowiące część systemu identyfikacji wizualnej uniwersytetu, w toku studiów najczęściej weryfikują jednak opinie na temat związku studiów dziennikarskich z problematyką teologiczną oraz rolą wykładowców wywodzących się z grona osób duchownych (w ankiecie nie pojawiła się ani jedna opinia, która świadczyłaby o ich niekompetencji w zakresie wykładanego przedmiotu, także o tematyce innej, niż teologiczna). 


\section{b. Wizerunek zewnętrzny}

Druga grupa pytań zorientowana była na kwestie wizerunku zewnętrznego.

Tab. 9. Odpowiedzi na pytanie: Jak (w opinii studentów UPJP2) inni widzą uczelnię?

\begin{tabular}{|l|l|l|l|}
\hline Prestiż (grupa podstawowa) & Wysoki & Sredni & Niski \\
\hline Prestiż (grupa ekspercka) & $3 \%$ & $58 \%$ & $39 \%$ \\
\hline & Wysoki & Sredni & Niski \\
\hline
\end{tabular}

Źródło - opracowanie na podstawie badań własnych.

Analiza porównawcza wykazuje, że w przypadku obu badanych grup studentów UPJPII uczelnia jest znacznie wyżej oceniana przez nich samych, niż - ich zdaniem - oceniana jest przez studentów innych uczelni (14,5\% więcej osób z grupy podstawowej i 9\% z grupy eksperckiej wskazało na niski prestiż uczelni woczach osób spoza uniwersytetu).

Bezpośrednio związana z poprzednim pytaniem była kwestia rozpoznawalności i specyfiki UPJPII w opinii środowiska zewnętrznego. Na pytanie o to, z czego słynie w oczach studentów innych uczelni, respondenci obu grup wymieniali zgodnie następujące (wg. częstotliwości wskazań): Jan Paweł II (łącznie 102 wskazania), księża i modlitwa (łącznie 88 wskazań), konserwatyzm (łącznie 49 wskazań), lokalizacja (łącznie 41 wskazań), organizacja Światowych Dni Młodzieży (łącznie 33 wskazania). Znacznie rzadziej pojawiały się następujące: „średniowiecze i zaściankowość w poglądach” (12 wskazań), uczelnia prywatna (11 wskazań), biblioteka (10 wskazań), praca tylko w instytucjach kościelnych (8 wskazań). Opinie te pozwalają zrozumieć, dlaczego studenci UPJPII mimo własnych, pozytywnych doświadczeń muszą na co dzień konfrontować się ze stereotypowymi wyobrażeniami na temat uczelni kościelnej.

\section{c. Wizerunek realny}

Wskazana wyżej dychotomia była punktem wyjścia do grupy pytań o wizerunek realny uczelni, a więc obraz, jaki można stworzyć w obecnych warunkach. Na pytanie o to, z czego może być dumny UPJPII, pojawiły się następujące grupy odpowiedzi: 1 . Patron (,Jan Paweł II” i ,,jedyny papieski w Polsce” - łącznie 77 wskazania), 2. Kadra (,znana kadra profesorska”, „popularni dziennikarze i redaktorzy” - łącznie 64 wskazania), 3. Studenci („osiągnięcia w konkursach”, „znani absolwenci” - łącznie 38 wskazań), 4. Media uniwersyteckie (,studio telewizyjne, radiowe i nagraniowe” - łącznie 32 wskazania), 5. Lokalizacja („,dobre umiejscowienie”, „wszędzie blisko” - łącznie 27 wskazań). W grupie eksperckiej pojawiła się (poza wymienionymi grupami) także dodatkowa kwestia: współpraca międzynarodowa („Erasmus”, „praktyki uczelniane”) - wskazanie u 1/3 respondentów.

W zakresie braków i „słabych punktów” związanych ze studiowaniem w UPJPII, wystąpiła absolutna dominacja niedostatków w zakresie funkcjonowania uczelni w Sieci - (Wirtualny Dziekanat, aktualizacja na stronach instytutowych), sprzętu techniczne- 

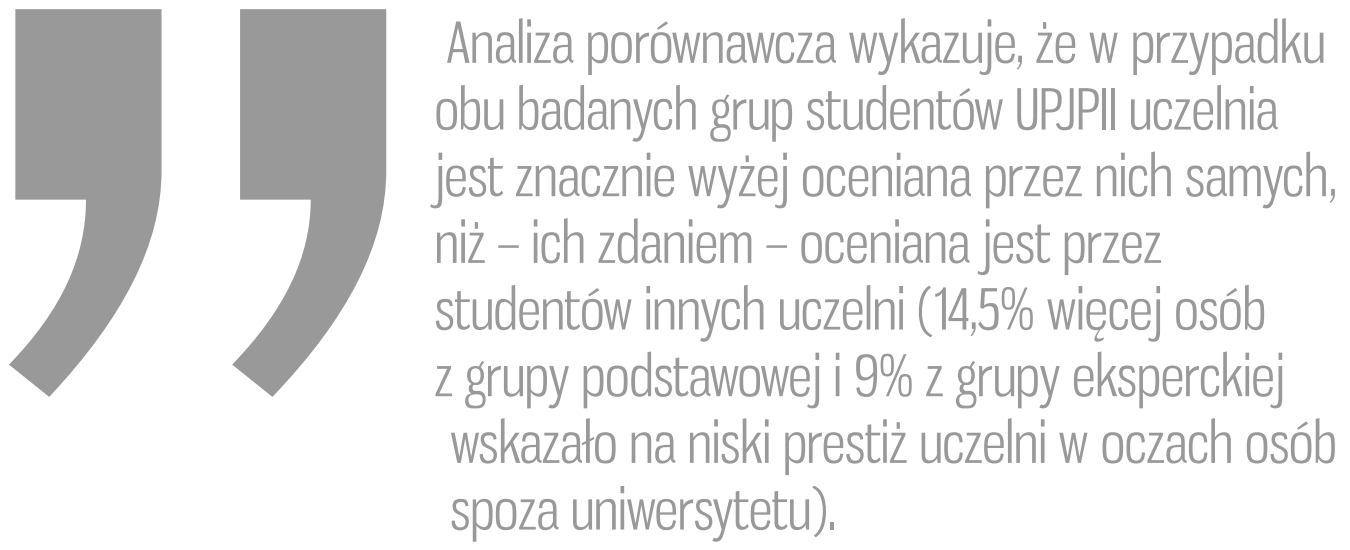

go będącego na wyposażeniu sal innych, niż studyjne (ksero, rzutnik, wskaźniki), brak komfortowych pomieszczeń dla studentów i krzeseł na korytarzach - łącznie 49\% respondentów w grupie podstawowej i aż 68\% w grupie eksperckiej. Co charakterystyczne, znacznie bardziej krytyczne spojrzenie miała w tej dziedzinie - bardziej przychylnie nastawiona w poprzednich wypowiedziach - grupa ekspercka. Na drugim planie znalazły się w grupie podstawowej zarzuty dotyczące „zbyt ogólnych przedmiotów” (u 8\% respondentów). Może mieć to związek z większą, niż w grupie studentów wyższych lat, dominacją wykładów o charakterze wprowadzającym do zagadnień bardziej szczegółowych. Równocześnie, w grupie eksperckiej pojawiły się zarzuty dotyczące ,zbyt małej promocji w mediach masowych” i „niepodejmowania konkurencji z innymi uczelniami” łącznie $12 \%$.

Ostatnie pytanie w obrębie grupy zagadnień dotyczących wizerunku realnego dotyczyło oceny obecnej strategii promocyjnej UPJPII.

Tab. 10. Wyniki opinii respondentów nt. jakości promocji uczelni.

\begin{tabular}{|l|l|l|l|l|l|}
\hline Ocena & B. dobrze (5) & Dobrze (4) & Średnio (3) & Miernie (2) & 亿́le (1) \\
\hline Grupa podstawowa & $23 \%$ & $31 \%$ & $23 \%$ & $19 \%$ & $4 \%$ \\
\hline Grupa ekspercka & $11 \%$ & $26 \%$ & $47 \%$ & $4 \%$ & $12 \%$ \\
\hline
\end{tabular}

Źródło - opracowanie na podstawie badań własnych.

Prezentowane wyniki wskazują na fakt, że chociaż studenci w grupie eksperckiej ogólnie bardziej cenią sobie walory badanego uniwersytetu, to jednak w kwestii oceny strategii promocyjnej i kampanii wizerunkowej są bardziej krytyczni, niż grupa podstawowa.

\section{d. Wizerunek idealny}

Ostatnia grupa zagadnień dotyczyła wizerunku idealnego. Respondenci byli pytani o to, jak chcą, by inni widzieli ich macierzysty uniwersytet. Na początku mieli oni określić, co należałoby eksponować w rzeczywistym obrazie uczelni (wykres 1.)? W grupie podstawowej wyodrębniono następujące kategorie: 
Wykres 1. Odpowiedzi respondentów na pytanie: Co eksponować w rzeczywistym obrazie UPJPII? (w \% wskazań) w grupie podstawowej.

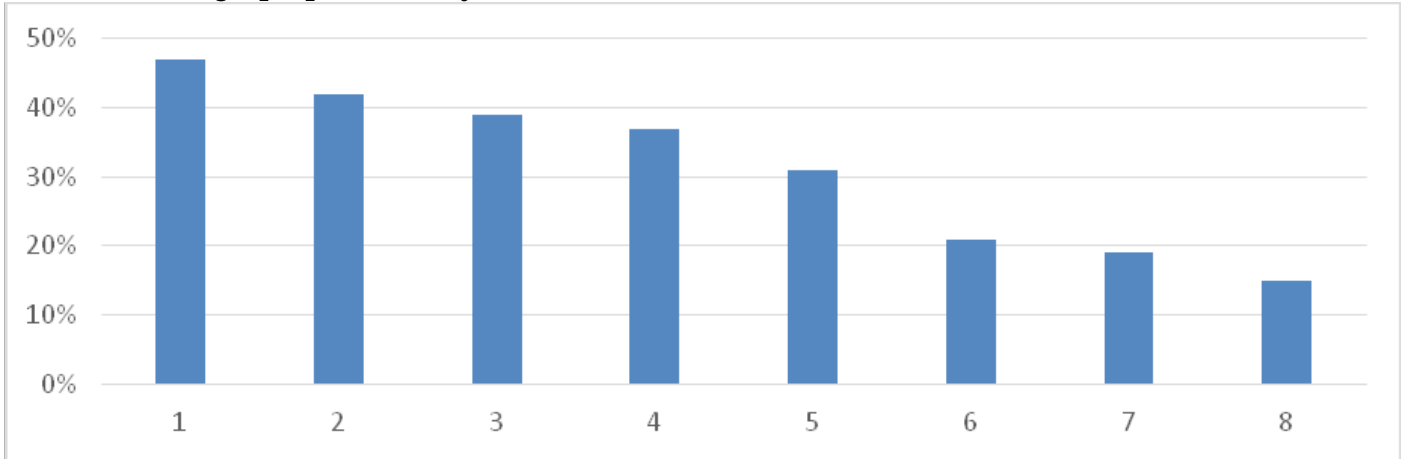

1. Patrona i katolicki charakter $-47 \%$.

2. Fakt, że są tu „świeckie” kierunki (WNS) a nie tylko teologiczne i filozoficzne - 42\%.

3. Lokalizację - 39\%.

4. Nowoczesne wyposażenie (TV, Radio, Inkubator przedsiębiorczości) - 37\%.

5. Osiągnięcia studentów - 31\%.

6. Duży patronat nad projektami studentów i troskę o studenta - 19\%.

7. Dobre warunki studiowania $-15 \%$.

8. Przyjazny klimat na uczelni - $21 \%$.

W grupie eksperckiej wskazano natomiast na następujące grupy tematów (wykres 2):

Wykres 2. Odpowiedzi respondentów na pytanie: Co eksponować w rzeczywistym obrazie UPJPII? (w\% wskazań) w grupie eksperckiej.

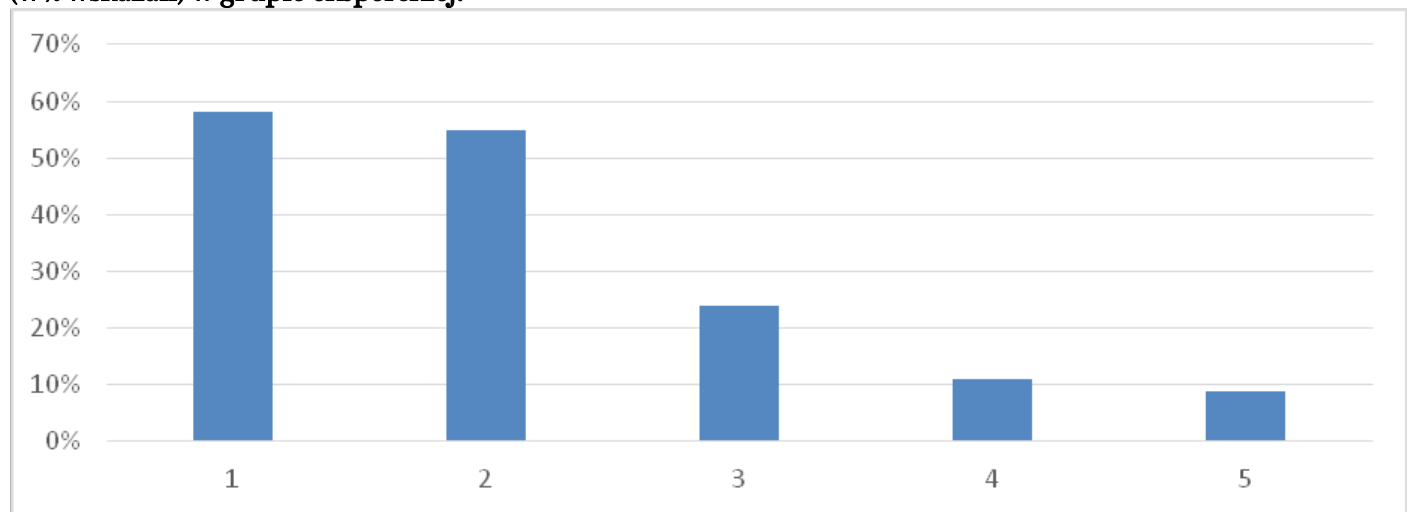

1. Profesjonalizm kadry i zaplecze techniczne (studia: radiowe, telewizyjne i nowych mediów, Inkubator przedsiębiorczości) - 58\%.

2. Patrona i wartości, jakie promuje uczelnia - $55 \%$.

3. Lokalizacja „w sercu Krakowa” - $24 \%$.

4. Integracja studentów i dobra współpraca w projektach - $11 \%$.

5. Szansa znalezienia pracy w zawodzie $-9 \%$.

6.

Źródło - opracowanie na podstawie badań własnych. 
Rozbieżności w stanowiskach obu grup wynikały z większej dostępności studentów wyższych lat (grupa ekspercka) do zaplecza technicznego (w programie studiów przedmioty o charakterze warsztatowym i treningowym), osobistego zaangażowania w tworzenie kampanii uczelnianej (trzon samorządu studenckiego), a także większej świadomości funkcjonowania na rynku pracy (praktyki, staże, etc.).

W podsumowaniu badań respondenci z grupy eksperckiej (zaznajomieni z tematyką PR) zostali dodatkowo zapytani o to, z jakich narzędzi powinno się korzystać w tworzeniu pozytywnego wizerunku i reputacji uczelni? Wśród najbardziej znaczących wymienili kontakty z mediami (media relations - wykres 3.) oraz zabiegi zmierzające do jednolitego postrzegania tożsamości i osobowości przez jej otoczenie w obrębie corporate identity (wykres 4.).

Wykres 3. Wyniki badań nad wskazaniem narzędzi kreowania pozytywnego wizerunku uczelni w zakresie relacji z mediami.

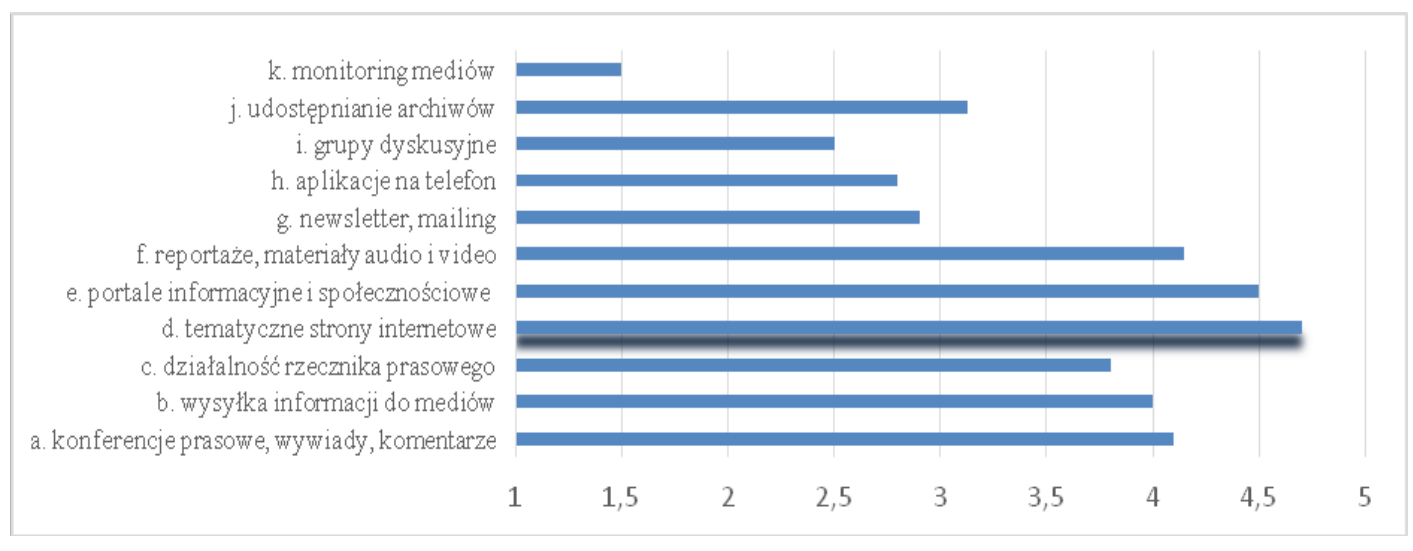

Źródło - opracowanie na podstawie badań własnych.

Na planie pierwszym znalazła się komunikacja zapośredniczona medialnie, w tym przede wszystkim w obrębie Sieci oraz mediów elektronicznych. Respondenci wskazywali na potrzebę korzystania z multimediów, co świadczyłoby o zauważalnej w całej przestrzeni medialnej, ale głównie wśród młodszej generacji jej użytkowników tendencji do funkcjonowania w świecie koegzystencji i synergii mediów.

Drugim narzędziem, na które wskazywali respondenci, była identyfikacja wizualna (corporate identity/visual identity). Badani respondenci z grupy eksperckiej najwyżej ocenili system identyfikacji wizualnej (znak graficzny i logotyp), w drugiej kolejności prezencję osób związaną z uniwersytetem, a na trzecim - przestrzeń i architekturę instytucji. Pozostałe wskazania w skali 5 (ważna) do 1 (nieistotna) były znacznie niższe. 
Wykres 4. Wyniki badań nad wskazaniem narzędzi kreowania pozytywnego wizerunku uczelni w zakresie identyfikacji wizualnej (CI).

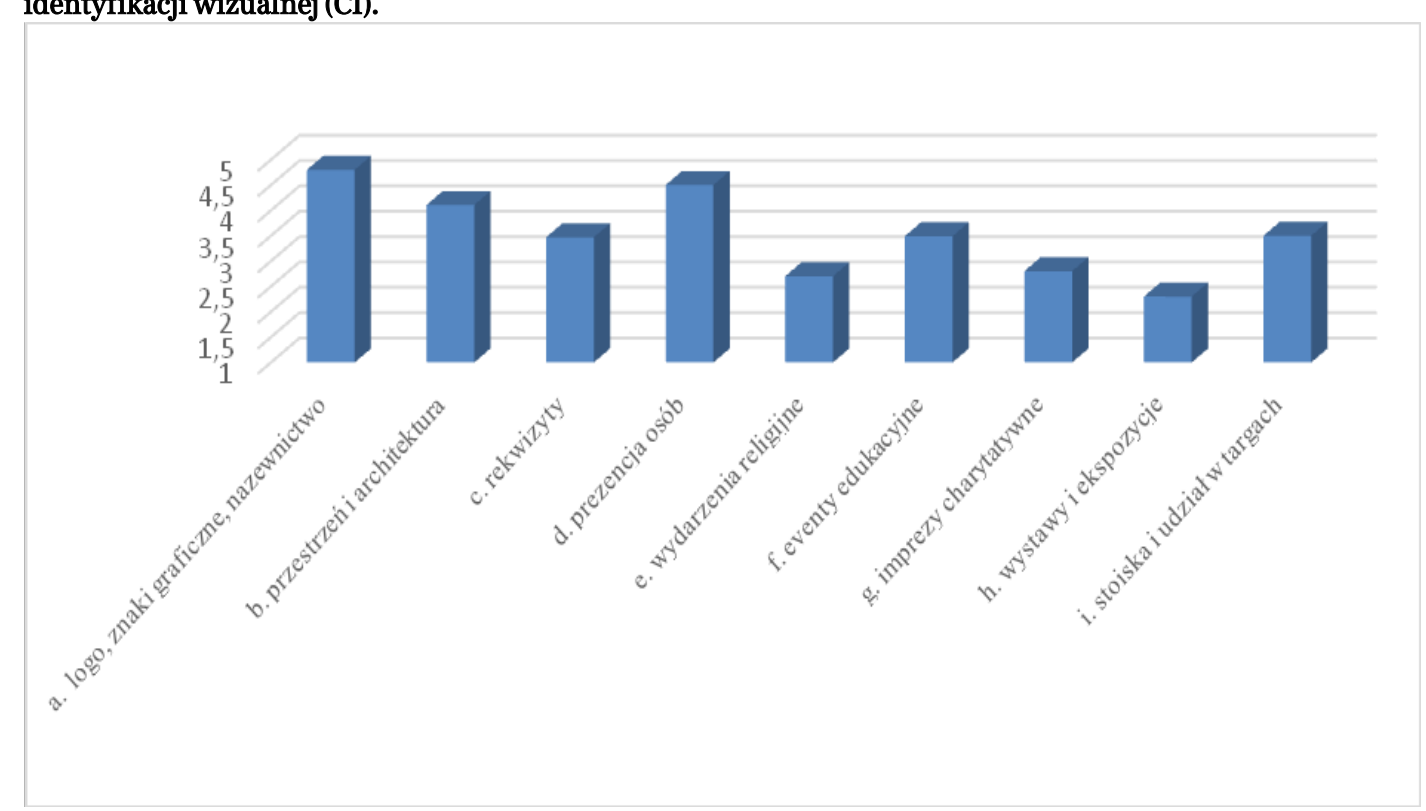

Źródło - opracowanie na podstawie badań własnych.

Analizując ten fragment ankiety można wywnioskować, iż jasno określona wizja kreowania wizerunku i spójny system znaków są - zdaniem badanych - podstawą budowania całościowej identyfikacji uczelni. Drugi wniosek, jaki można postawić w wyniku przeprowadzonych analiz, to fakt, że czynnik ten jest bardzo istotny i pomaga w znaczący sposób w tworzeniu porozumienia z otoczeniem. Kompatybilność, wspomniana spójność i odpowiedniość to rudymentarne cechy pozytywnej oceny w obszarze CI.

\section{Wnioski i rekomendacje}

Cechą każdego uniwersytetu jest autonomia, która - zdaniem Dominika Antonowicza nadaje mu uprawnienia o charakterze samorządowym ${ }^{15}$, ale mimo tych dwóch obszarów każdy uniwersytet funkcjonuje równocześnie w przestrzeni rynkowej. Zarządzający takimi placówkami zobowiązani są zatem do utrzymania jak najlepszych stosunków z grupami interesariuszy, jako czynników przyciągających potencjalnych studentów, wyróżniając się na tle wielu państwowych i prywatnych uczelni wyższych. Spełnianie nawet najwyższych standardów jakości musi być wsparte w obszarze relacji z otoczeniem tak, by z dobrymi praktykami, atrakcyjnymi formami studiowania i perspektywą wyboru ścieżki zawodowej mogło zapoznawać się otoczenie tej instytucji. Niewątpliwie zabiegi typu public relations w obszarze tożsamości i wizerunku, zmierzające do relewancji obu pojęć są naj-

${ }^{15}$ D. Antonowicz, Uniwersytet przyszłości. Wyzwania i modele polityki, Warszawa 2005. 
ważniejszym celem specjalistów zajmujących się relacjami tego typu jednostek ze środowiskiem zewnętrznym, a więc zarządzaniem (corporate behaviour), dbaniem o kulturę organizacji (corporate design), jej komunikację z otoczeniem (corporate communications) $\mathrm{w}$ trosce o rozwój i budowę potencjału instytucji (corporate intelligence).

Pojmując działania w zakresu media i public relations jako chęć „nawiązywania stosunków dla powszechnego dobra ${ }^{16}$ " i ,sztukę i naukę osiągania harmonii z otoczeniem" ${ }^{17}$, należałoby stwierdzić, że w środowisku uniwersyteckim aktywność na tych polach jest podejmowana nie od dziś. Jeszcze bliższe dla tych obszarów byłoby określenie Jerzego Olędzkiego, który mówi wręcz o tworzeniu wspólnoty, stawiając troskę o reputację rozumianą jako „rozwiniętą formę dwustronnie partnerskiej komunikacji” ${ }^{18}$ ponad innymi formami komunikowania społecznego ${ }^{19}$. Taki sposób podejścia do wykorzystania narzędzi medialnych i PR jest charakterystyczny przede wszystkim w obszarach niekomercyjnych, choć i w przypadku instytucji zorientowanych na zysk rośnie odsetek firm nastawionych na dążenie do owej harmonii (choćby działania z zakresu $\operatorname{CSR}^{20}$ ). Uczelnie wyższe, w tym uniwersytety, są na tym tle hybrydami, ponieważ ich głównym celem jako „universitas magistrorum et scholarium” jest kształcenie kadr naukowców. Można więc w ich przypadku mówić o misyjności i nastawieniu na wyższe wartości. Dodatkowo, uniwersytet, który od początku swojej działalności, w oparciu o myśl głównego patrona - Jana Pawła II, promuje wizję personalizmu opartego nad szacunku i godności drugiego człowieka - także za pośrednictwem mediów, praktycznie realizując to działanie m.in. w Instytucie Dziennikarstwa i Komunikacji Społecznej, łączy w sobie sztukę tworzenia wspólnoty, o której pisał wspomniany autor „Prologu nowego etapu komunikacji społecznej” z odpowiedzialnością za „wydobywanie dobra z medialnego cienia”"21, o czym w licznych publikacjach na temat aksjologicznego i wychowawczego aspektu mediów i budowie relacji za ich pośrednictwem, przypomina Michał Drożdż.

\section{Zakończenie}

Niniejszy artykuł podejmuje zaledwie jeden z aspektów szeroko rozumianego public relations i sprowadza się do oceny czterech typów wizerunku - od wizerunku zwykłego, aż po idealny, w celu poszukiwania jak najsilniejszej korelacji między nim a tożsamością

\footnotetext{
${ }^{16}$ K. Wójcik, Public relations od A do Z, t. 1, Warszawa 1997, s. 113.

${ }^{17}$ S. Black, Public Relations, Warszawa 1999, s. 15.

${ }^{18} \mathrm{~J}$. Olędzki, Prolog nowego etapu komunikacji społecznej, [w:] tenże, Media, reklama i public relations w Polsce, Warszawa 2005, s. 18 i n.

${ }^{19}$ J. Olędzki, Public relations w komunikacji społecznej, [w:] J. Olędzki, D. Tworzydło, Public relations. Znaczenie społeczne i kierunki rozwoju, Warszawa 2007, s. 26. Sam Black wręcz określa PR, jako: „sztukę i naukę osiągania harmonii z otoczeniem”, zob. S. Black, Public Relations, Warszawa 1999, s. 15.

${ }^{20}$ Ł. Makuch, Normy i standardy społecznej odpowiedzialności biznesu (CSR). Przewodnik po kluczowych standardach społecznej odpowiedzialności biznesu oraz relacjach $i$ współzależnościach pomiędzy nimi zachodzących, Warszawa 2011, s. 30.

${ }^{21}$ Zob. M. Drożdż, Wydobyć dobro z medialnego cienia, [w:] A. Baczyński i M. Drożdż (red.), Dobro w mediach. $Z$ cienia do światta, Tarnów 2012, s. 15-36.
} 


\section{PUBLIC RELATIONS W INSTYTUCJACH NON-PROFIT}

instytucji, zgodnie z zasadą, iż pomiędzy wizerunkiem pożądanym i tożsamością można postawić znak równości ${ }^{22}$. Opis pod kątem przydatności wykorzystania innych narzędzi public relations wydaje się naturalną kontynuacją zamieszczonych tu badań, które będą podejmowane w przyszłości. Analizy opinii publicznej, a także badania marketingowe rozumiane za A. Parasuramanem jako „zbiór zasad i technik systematycznego gromadzenia, zapisywania, analizowania i interpretacji informacji ${ }^{23}$ " $\mathrm{w}$ celu podejmowania coraz lepszych decyzji, winny mieć wymiar ciągły. Jak podkreśla Agnieszka Smalec: „Aby można było mówić o ich praktycznej przydatności, powinny być one wykorzystywane w sposób systematyczny i staranny" ${ }^{24}$.

Na podstawie wyników badań, przedstawionych w niniejszym artykule, należy stwierdzić, że w sytuacji powszechnego dostępu do nowych mediów (w tym mediów społecznościowych) i popularności urządzeń oraz aplikacji do szybkiej komunikacji, sfera komunikacji wizualnej (corporate identity) i jakość tych kontaktów z wykorzystaniem narzędzi media relations, powinny znaleźć się w centrum zainteresowania zarządzających taką instytucją, jak katolicki Uniwersytet Papieski Jana Pawła II - biorąc zawsze pod uwagę opisane przez Polskie Stowarzyszenie Doradcze i Konsultingowe ${ }^{25}$ podstawowe zasady etyki PR, tj. rzetelność informacyjną, konstruktywny kontakt z otoczeniem i wreszcie otwartość komunikacyjną.

\section{BIBLIOGRAFIA:}

Altkorn J., Wizualizacja firmy, Kraków 1999.

Antonowicz D., Uniwersytet przyszłości. Wyzwania i modele polityki, Warszawa 2005.

Baczyński A., Drożdż M. (red.), Dobro w mediach. Z cienia do światta, Tarnów 2012.

Black S., Public Relations, Warszawa 1999.

Daszkiewicz M., Wrona S., Kreowanie marki korporacyjnej, Warszawa 2014.

Duliniec E., Badania marketingowe w zarządzaniu przedsiębiorstwem, Warszawa 1999.

Gamst G., Meyers L. S., Guarino A. J., Analysis of Variance Designs. A Conceptual and Computational Approach with SPSS and SAS, Cambridge 2008.

Garbarski L., Rutkowski I., Wrzosek W., Marketing: Punkt zwrotny nowoczesnej firmy, Warszawa 2000.

Gray E. E., Balmer J., Managing corporate image and corporate reputation, "Long Range Planning” nr 31 (5), 1998.

\footnotetext{
${ }^{22}$ R. S. Kaplan, D. P. Norton, Wdrażanie strategii dla osiągnięcia przewagi konkurencyjnej, przeł. G. Łuczkiewicz, Warszawa 2010, por. J. Altkorn, Wizualizacja firmy, Kraków 1999.

${ }^{23}$ A. Parasuraman, Marketing Research, Cambridge, 1986, s. 5.

${ }^{24}$ A. Smalec, Marketing: Sposób myślenia i działania, dz. cyt., s. 53.

${ }^{25}$ Polskie Stowarzyszenie Doradcze i Konsultingowe, Etyka w Public Relations, http://www.biznesklaster.pl/company/article/163-etyka-w-public-relations/ (dostęp 11.10.2017).
} 
Kaplan R. S., Norton D. P., Wdrażanie strategii dla osiągnięcia przewagi konkurencyjnej, przeł. G. Łuczkiewicz, Warszawa 2010.

Kotler P., Marketing, Warszawa 1994.

Kubiak K. (red.), Zarządzanie w sytuacjach kryzysowych niepewności, Warszawa 2012.

Makuch Ł., Normy i standardy społecznej odpowiedzialności biznesu (CSR). Przewodnik po kluczowych standardach społecznej odpowiedzialności biznesu oraz relacjach i wspótzależnościach pomiędzy nimi zachodzących, Warszawa 2011.

Olędzki J., Prolog nowego etapu komunikacji społecznej, [w:] tenże, Media, reklama i public relations w Polsce, Warszawa 2005.

Olędzki J., Public relations w komunikacji społecznej, [w:] J. Olędzki, D. Tworzydło, Public relations. Znaczenie społeczne i kierunki rozwoju, Warszawa 2007.

Parasuraman A., Marketing Research, Cambridge 1986.

Perenc J. (red.), Marketing. Sposób myślenia i działania, Szczecin 2001.

Polskie Stowarzyszenie Doradcze i Konsultingowe, Etyka w Public Relations, http://www.biznesklaster.pl/company/article/163-etyka-w-public-relations/.

Strzyżewska M., Rószkiewicz M., Analizy marketingowe, Warszawa 2002.

Uniwersytet Papieski Jana Pawła II w Krakowie, http://www.upjp2.edu.pl/? q=uczelnia/uczelnia/o-nas/historia.

Wójcik K., Public relations od A do Z, t. 1, Warszawa 1997.

\section{O AUTORCE:}

dr Klaudia Cymanow-Sosin, zastępca Dyrektora Instytutu Dziennikarstwa i Komunikacji Społecznej Uniwersytetu Papieskiego Jana Pawła II w Krakowie, specjalista w zakresie media relations, komunikacji wizerunkowej i public relations. Wydawca, wspó1autorka programów telewizyjnych i radiowych, doradca ds. mediów, autorka książek, m.in. Metafory we wspólczesnej reklamie, publikacji naukowych i publicystycznych, wiceprzewodnicząca rady programowej Radia Kraków, członek Komisji Medioznawczej PAU i Polskiego Towarzystwa Komunikacji Społecznej.

KONTAKT:klaudia.cymanow_sosin@upjp2.edu.pl 
KuLTura- MeDia-TeoLogia

ISSN 2081-8971

$2017 \mathrm{nr} 30$, s. 30-51.

\section{Jak zwiększyć skuteczność organizacji non profit korzystając z social media? Case study na podstawie wybranych fundacji katolickich}

How to increase the effectiveness of non-profit organizations using social media? Case study based on selected Catholic foundations

\begin{abstract}
ABSTRAKT:
NA PRZYKEADZIE WYBRANYCH ORGANIZACJI POŻYTKU PUBLICZNEGO (KATOLICKICH I ŚWIECKICH) POKAZUJE,

JAK WYKORZYSTAĆ MEDIA SPOŁECZNOŚCIOWE DO PROMOCJI DZIAEAŃ NON PROFIT ORAZ ZWIĘKSZENIA SKUTECZNOŚCI FUNDACJI. PREZENTUJE WYNIKI BADAŃ MONITORINGU MEDIÓW NA TEMAT OBECNOŚCI WYBRANYCH FUNDACJI W INTERNECIE, A DLA SFORMUŁOWANIA ZASAD KOMUNIKACJI W SOCIAL MEDIA PODDAJĘ ANALIZIE KANAEY SOCIAL MEDIA NAJWIĘKSZYCH POLSKICH ORGANIZACJI POŻYTKU PUBLICZNEGO.
\end{abstract}

\section{SŁOWA KLUCZOWE:}

NON PROFIT, DOBROCZYNNOŚĆ, MEDIA SPOŁECZNOŚCIOWE, KOMUNIKACJA

\begin{abstract}
:
BASED ON EXAMPLES OF SOME PUBLIC BENEFIT ORGANIZATIONS (CATHOLIC AND SECULAR), AUTHOR SHOWS HOW TO USE THE SOCIAL MEDIA TOOLS TO PROMOTE NON-PROFIT ACTIVITIES AND THEREBY INCREASE THEIR EFFECTIVENESS. AUTHOR PRESENTS THE RESULTS OF MEDIA MONITORING ON THE PRESENCE OF SELECTED FOUNDATIONS ON THE INTERNET, AND TRY TO FORMULATE GOOD RULES OF COMMUNICATION IN SOCIAL MEDIA CHANNELS BY ANALYSIS THE LARGEST POLISH PUBLIC BENEFIT ORGANIZATIONS.
\end{abstract}

\section{KEYWORDS:}

NON-PROFIT ORGANIZATION, CHARITY, SOCIAL MEDIA, COMMUNICATION 
$\mathrm{C}$ elem tekstu jest prezentacja wybranych narzędzi mediów społecznościowych, które mogą posłużyć promocji działalności charytatywnej, a co za tym idzie, zwiększyć skuteczność organizacji non profit. Punktem wyjścia do podjęcia refleksji na temat social media w kontekście dobroczynności jest stosunek Polaków do fundacji charytatywnych, zarówno tych kościelnych, jak i świeckich. Następnie przedstawiona zostanie aktywność wybranych organizacji non profit w mediach internetowych. W tym celu korzystam z takich metod badawczych, jak analiza i synteza. Analizie poddaję kanały społecznościowe wybranych polskich organizacji charytatywnych. Dla uzyskania niezbędnych danych odwołuję się do monitoringu mediów przeprowadzonego z wykorzystaniem narzędzi firmy Newspoint. Na końcu formułuję w syntetyczny sposób dobre praktyki w social media, z których warto korzystać tworząc politykę komunikacyjną organizacji non profit.

\section{Teza, hipotezy badawcze}

Z podjętej analizy mediów społecznościowych wynika, że polskie organizacje charytatywne aktywnie korzystają z nowoczesnych kanałów komunikacji, dzięki czemu docierają z przekazem do szerokiego grona odbiorców. Skłania to do postawienia tezy, że umiejętne zastosowanie narzędzi social media może zwiększyć skuteczność organizacji non profit. Formułując hipotezy i problemy badawcze należy podkreślić opisane poniżej kwestie:

- stosunek Polaków do organizacji non profit jest pozytywny - co roku przeznaczają coraz większe kwoty na działalność wybranych fundacji,

- ważnym elementem polityki informacyjnej organizacji non profit jest obecność w internecie oraz w nowoczesnych kanałach komunikacji,

- umiejętne wykorzystanie narzędzi social media przez organizacje non profit wzmacnia komunikaty przekazywane w tradycyjnych mediach, może też skutkować zwiększeniem zasięgu organizacji i poszerzaniem grona odbiorców.

\section{Polacy wspierają organizacje pożytku publicznego}

Z danych Ministerstwa Finansów za poszczególne lata wynika, że Polacy chętnie przeznaczają pieniądze na fundacje dobroczynne. W zeznaniu podatkowym za 2012 r. aż 44\% Polaków (ok. 11,5 mln osób) przekazało odpis 1\% organizacjom pożytku publicznego (dalej: OPP). Głównymi beneficjantami ofiarności są fundacje działające na rzecz chorych dzieci i osób niepełnosprawnych. Polacy darzą zaufaniem organizacje kościelne oraz hospicja i fundacje wspierające osoby potrzebujące. Na konta ponad 7 tys. podmiotów wpłynęło $480 \mathrm{mln} \mathrm{zł}^{1}$.

Wśród 5. najchętniej wspieranych organizacji są: Fundacja Dzieciom „Zdążyć z pomocą" (117,2 mln zł), Fundacja Pomocy Osobom Niepełnosprawnym „Słoneczko” (15,3 mln zł), Avalon - Bezpośrednia Pomoc Niepełnosprawnym (8,5 mln zł), Fundacja „Rosa” (8 mln zł) oraz Fundacja Anny Dymnej „Mimo Wszystko” (6,2 mln zł). W pierwszej 30. beneficjentów $1 \%$ znalazło się wiele organizacji charytatywnych związanych z Kościołem katolickim i związkami wyznaniowymi. 2,9 mln zł (21. miejsce) otrzymała

\footnotetext{
${ }^{1}$ LK/Warszawa/KAI, 44 proc. Polaków wsparło organizacje pożytku publicznego, http://www.niedziela.pl/artykul/6526/44-proc-Polakow-wsparlo-organizacje, (dostęp: 28.12.2017 r.).
} 
Fundacja „Dzieło Nowego Tysiąclecia” (dalej: „DNT”), która tworzy fundusz stypendialny dla zdolnej młodzieży z ubogich rodzin. Na 23. miejscu znalazła się organizacja Caritas Polska, na którą Polacy przekazali 2,6 mln zł².

Jeszcze więcej pieniędzy organizacje otrzymały w kolejnych latach. Ze sprawozdania za rok 2013 wynika, że łączna kwota przekazana na rzecz OPP wyniosła 506,6 mln zł. Ponownie na pierwszym miejscu znalazła się fundacja „Zdążyć z pomocą” (ponad $127 \mathrm{mln}$ zł). W pierwszej 5. beneficjentów raport wymienia: „Słoneczko” (17,6 mln zł), Avalon (11,6 mln zł), „Rosę” (8,7 mln zł) oraz Fundację Nasza Szkoła (6,1 mln zł). Fundacja Anny Dymnej znalazła się na 8. miejscu (5,2 mln zł). OPP związane z Kościołem znalazły się poza pierwszą 30 . - Caritas na 35. pozycji (1,9 mln zł), Chrześcijańska Służba Charytatywna na 51. (1,3 mln zł), Dzieło Pomocy św. Ojca Pio na 52. (1,2 mln zł), „DNT” na 60 miejscu (1,1 mln zł $)^{3}$.

Sytuacja przedstawia się podobnie w rozliczeniu za następny rok. Łączna kwota $1 \%$ przekazana na rzecz OPP w 2014 wyniosła 557,6 mln zł. Pierwsze cztery miejsca pozostają bez zmian - „Zdążyć z pomocą” uzyskała wsparcie 136,1 mln zł, „Słoneczko” - 20,7 mln zł, Avalon - 15,7 mln zł, „Rosa” - 10,3 mln zł. Na 5. pozycji znalazła się Fundacja Studencka „Młodzi - Młodym” (8,2 mln zł). Na wysokiej 10. pozycji była związana z Radiem Maryja Fundacja „Nasza Przyszłość”. Caritas zajął 59. miejsce (1,3 mln zł), a „DNT” 119. miejsce $(555 \text { tys. })^{4}$.

\section{Wybrane organizacje non profit w social media - wyniki monitoringu mediów}

Celem tekstu jest zaprezentowanie wybranych narzędzi mediów społecznościowych, które mogą pomóc w zwiększeniu skuteczności organizacji non profit. Dla sformułowania zasad dotyczących polityki social media niezbędne jest podjęcie refleksji na temat działania wybranych OPP w nowoczesnych kanałach komunikacji. Przedmiotem analizy są fundacje kościelne, dlatego przeprowadziłam monitoring mediów internetowych dla Caritas Polska oraz „DNT”. Medialną politykę fundacji katolickich skonfrontuję ze strategią największych świeckich fundacji. Dla porównania wybrałam fundację Anny Dymnej oraz „Zdążyć z pomocą”, które utrzymują się w czołówce najchętniej wspieranych przez Polaków OPP.

Analizie poddaję ponadto działania promujące Szlachetną Paczkę. Wprawdzie sam projekt nie należy do kategorii OPP, jednak jest realizowany przez Stowarzyszenie „Wiosna”, które w 2014 znalazło się na 46. miejscu wspieranych przez Polaków organizacji (1,43 mln zł). Warto przyjrzeć się Szlachetnej Paczce, ponieważ organizacja prowadzi

\footnotetext{
${ }^{2}$ LK/Warszawa/KAI, 44 proc. Polaków..., dz. cyt.

${ }^{3}$ Ministerstwo Finansów, Informacja dotycząca kwot 1\% należnego podatku dochodowego od osób fizycznych przekazanych organizacjom pożytku publicznego z rozliczenia za 2013 rok, http://www.finanse.mf.gov.pl/documents/766655/2970107/Wykaz+organizacji+po \%C5\%BCytku+publicznego\%2C+kt\%C3\%B3re+w+2014+r.+otrzyma\%C5\%82y+1+proc., (dostęp: 28.12 .2017 r.).

${ }^{4}$ Ministerstwo Finansów, Informacja dotycząca kwot 1\% należnego podatku dochodowego od osób fizycznych przekazanych organizacjom pożytku publicznego z rozliczenia za 2014 rok, http://www.finanse.mf.gov.pl/documents/766655/5008832/Wykaz+organizacji+po\%C5\%BCytku+publicznego $\% 2 \mathrm{C}+\mathrm{kt} \% \mathrm{C} 3 \% \mathrm{~B} 3 \mathrm{re}+\mathrm{w}+2015+$ otrzyma\%C5\%82y+kwoty+1+proc., (dostęp: 28.12.2017 r.).
} 
profesjonalną komunikację w mediach społecznościowych, co odzwierciedlają statystyki . W 2014 (14. edycja) aktywność w dodawaniu postów akcji wzrosła o 76 proc. w stosunku do roku 2013. Aż 88\% wszystkich wzmianek w mediach na temat Szlachetnej Paczki pochodziło z Facebooka. Media tradycyjne dostarczają kilku procent komunikatów radio $(6 \%)$, prasa (4\%) oraz telewizja (2\%). Wzrost publikacji w 2014 wyniósł 33\% ogółem oraz $76 \%$ na Facebooku. Na drugim miejscu znalazł się Twitter (8\%), na kolejnych plus.google.com oraz inne (po $2 \%)^{5}$.

Dla uzyskania danych przeprowadziłam analizę mediów internetowych korzystając z narzędzi firmy Newspoint. Uzyskane materiały ukazały się w okresie pomiędzy 1 maja 2015 a 31 października 2015. Uwzględnione w badaniu serwisy to tradycyjne strony WWW, fora, blogi, społeczności, mikroblogi, opinie, video oraz zdjęcia. Za wybraną jednostkę analizy uznałam post zawierający przynajmniej jedno wystąpienie słowa kluczowego (w większości nazwy własne fundacji).

\section{- Fundacja Anny Dymnej „Mimo wszystko”}

W okresie sześciu miesięcy ukazało się 1580 publikacji. Większość z nich $(67,8 \%)$, to materiały z mediów społecznościowych. Na 2. pozycji znalazły się strony www $(28,2 \%)$, na kolejnych video $(1,6 \%)$, mikroblogi $(1,3 \%)$, fora $(0,6 \%)$, blogi $(0,3 \%)$ oraz opinie i zdjęcia (po $0,1 \%$ ).

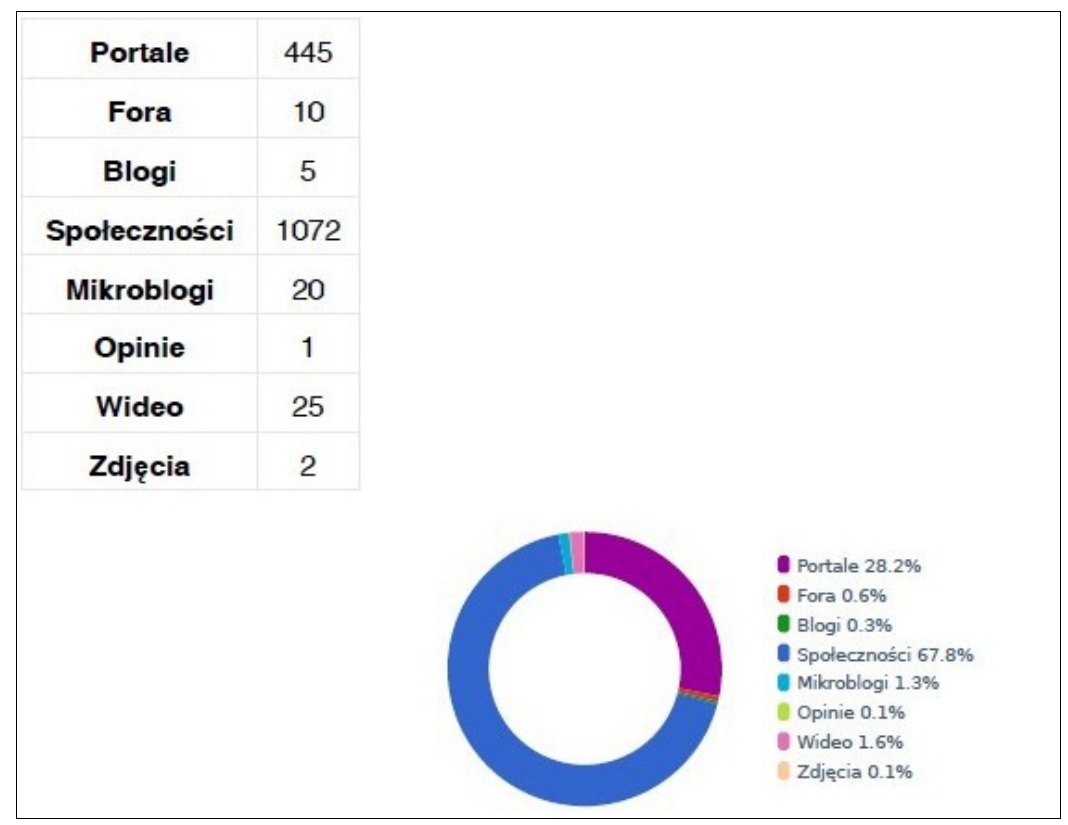

Grafika 1: Wzmianki o fundacji „Mimo wszystko” w badanym okresie (Newspoint.pl/badanie własne)

\footnotetext{
${ }^{5}$ M. Marchwicki, Szlachetna Paczka bije rekordy na Facebooku, http://socialpress.pl/2014/12/szlachetnapaczka-bije-rekordy-na-facebooku/, (dostęp: 28.12.2017 r.).
} 


\section{PUBLIC RELATIONS W INSTYTUCJACH NON-PROFIT}

Publikacje mają wydźwięk pozytywny (809). Za neutralne uznano 238 wypowiedzi, za negatywne - 1, z kolei 43 zostały zakwalifikowane jako nieocenione. Raport uwzględnia ponadto zmianę w liczbie i wydźwięku publikacji, jaką odnotowano w okresie analogicznym do badanego, ale bezpośrednio go poprzedzającym (tj. 1 grudnia 2014 - 30 kwietnia 2015). Publikacji przybyło o 144\%. Największy wzrost dotyczy komentarzy nieocenionych $290,9 \%$. Odnotowano wzrost materiałów pozytywnych o 163,5\%, neutralnych o 51,6\%. Komentarzy negatywnych było mniej o 66,7\%.

\begin{tabular}{c|c|c|c|c|c|}
\hline & Pozytywne & Neutralne & Negatywne & Nieocenione & Wszystkie \\
\hline $\begin{array}{c}\text { Liczba } \\
\text { wypowiedzi }\end{array}$ & 809 & 238 & 1 & 43 & 1091 \\
\hline Zmiana & $163.5 \%$ & $51.6 \%$ & $-66.7 \%$ & $290.9 \%$ & $144 \%$ \\
\hline
\end{tabular}

Grafika 2: Wydźwięk publikacji o fundacji „Mimo wszystko” (badanie własne/Newspoint.pl)

Największy wzrost publikacji da się zaobserwować pomiędzy 22. a 23. tygodniem, spadek ok. 26. tygodnia. Jeśli chodzi o miejsca, w których najczęściej pojawiały się wzmianki na temat fundacji, to widać, iż przeważa Facebook. Kolejne portale to Wosp.org, YouTube, Twitter, Polskie Radio, Onet.pl, Gazeta.pl. TVP, Interia oraz Super Express.

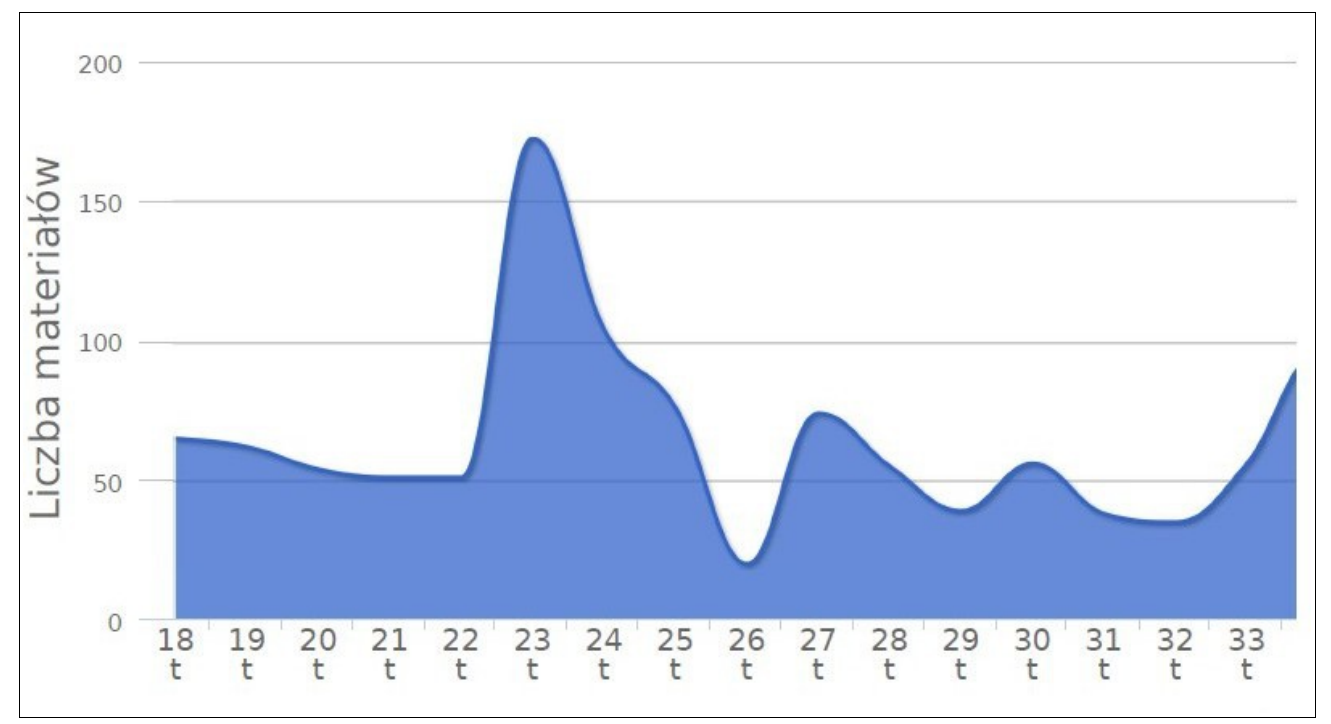

Grafika 3: Rozłożenie w czasie wyników dotyczących fundacji „Mimo wszystko” (badanie własne/Newspoint.pl) 


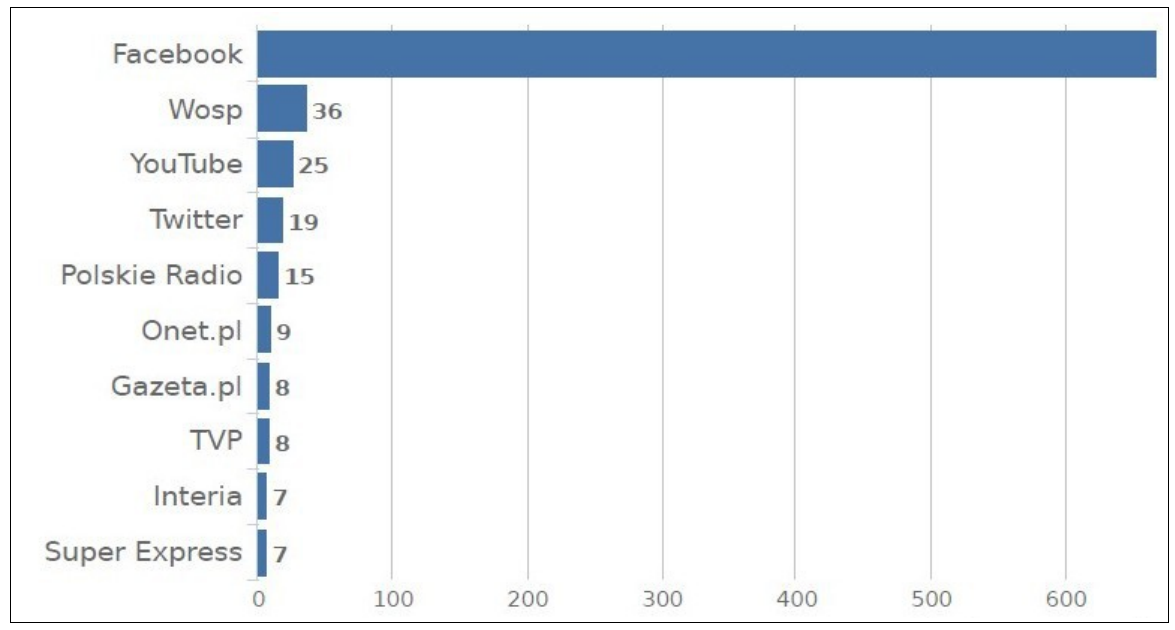

Grafika 4: Serwisy, w których najczęściej dyskutowano o fundacji „Mimo wszystko” (badanie własne/Newspoint.pl)

- Fundacja Dzieciom „Zdążyć z pomocą”

W badanym półroczu ukazało się 2816 materiałów, z których 2164 (76,8\%) to publikacje na Facebooku. Na stronach www ukazało się 19,5\% artykułów, na blogach 1,8\%, na forach $1 \%$. Materiały video to $0,6 \%$ oraz mikroblogi $-0,2 \%$ publikacji.

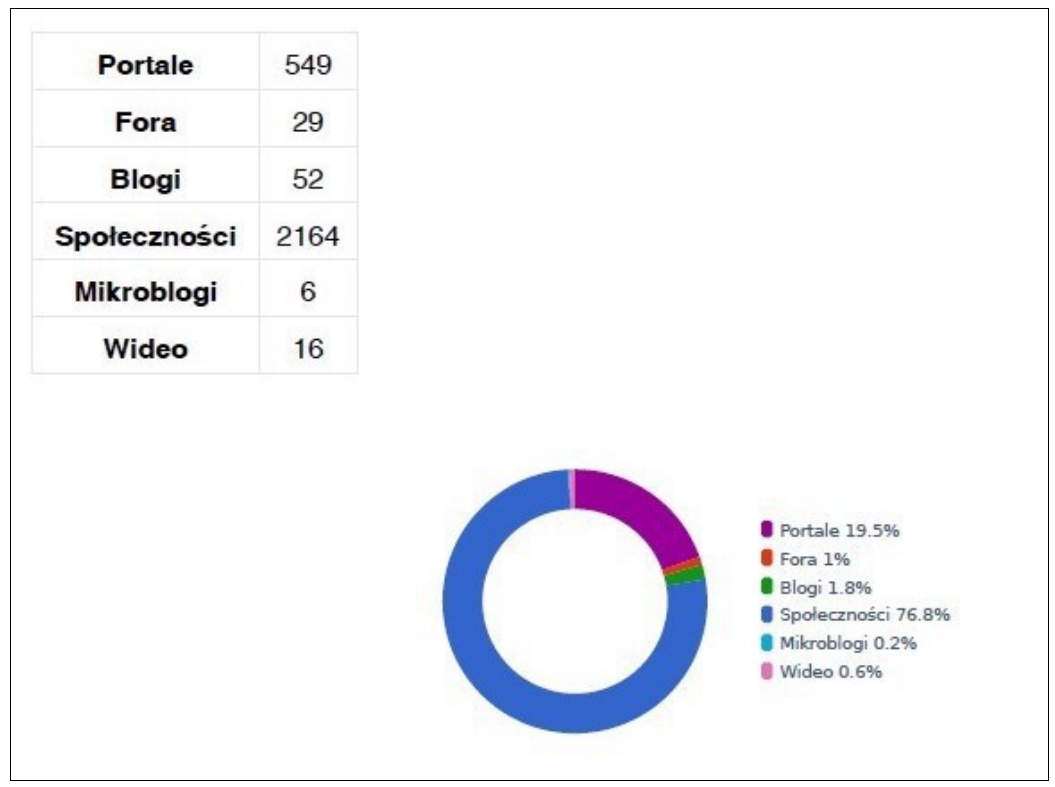

Grafika 5: Wzmianki o fundacji „Zdążyć z pomocą” w badanym okresie (badanie własne/Newspoint.pl) 


\section{PUBLIC RELATIONS W INSTYTUCJACH NON-PROFIT}

Większość materiałów (1958) zostało ocenionych jako neutralne, 399 jako pozytywne, zaś 301 jako negatywne. Za niemożliwe do oceny uznano 136 publikacji. Zmiana, która nastąpiła w analizowanym półroczu w stosunku do poprzedniego to $62 \%$, w tym: spadek negatywnych o $70,2 \%$, neutralnych o $67,7 \%$, pozytywnych o $58,4 \%$. Wzrosła liczba publikacji nieocenionych - o 33,3\%.

\begin{tabular}{|c|c|c|c|c|c|}
\hline \hline & Pozytywne & Neutralne & Negatywne & Nieocenione & Wszystkie \\
\hline $\begin{array}{c}\text { Liczba } \\
\text { wypowiedzi }\end{array}$ & 399 & 1958 & 301 & 136 & 2794 \\
Zmiana & $-58.4 \%$ & $-67.7 \%$ & $-70.2 \%$ & $33.3 \%$ & $-62 \%$ \\
\hline
\end{tabular}

Grafika 6: Wydźwięk publikacji o fundacji „Zdążyć z pomocą” (badanie własne/Newspoint.pl)

Największy wzrost publikacji odnotowano pomiędzy 18. a 19. tygodniem oraz pomiędzy 29. a 31. tygodniem, zaś największy spadek - w 27. tygodniu. Ponownie największa liczba podejmowanych dyskusji odnosiła się do Facebooka. Kolejne serwisy to: Blox, YouTube, Google+, Wirtualna Polska, Blog olx, TVP, Super Express, NGO.pl oraz Onet.pl.

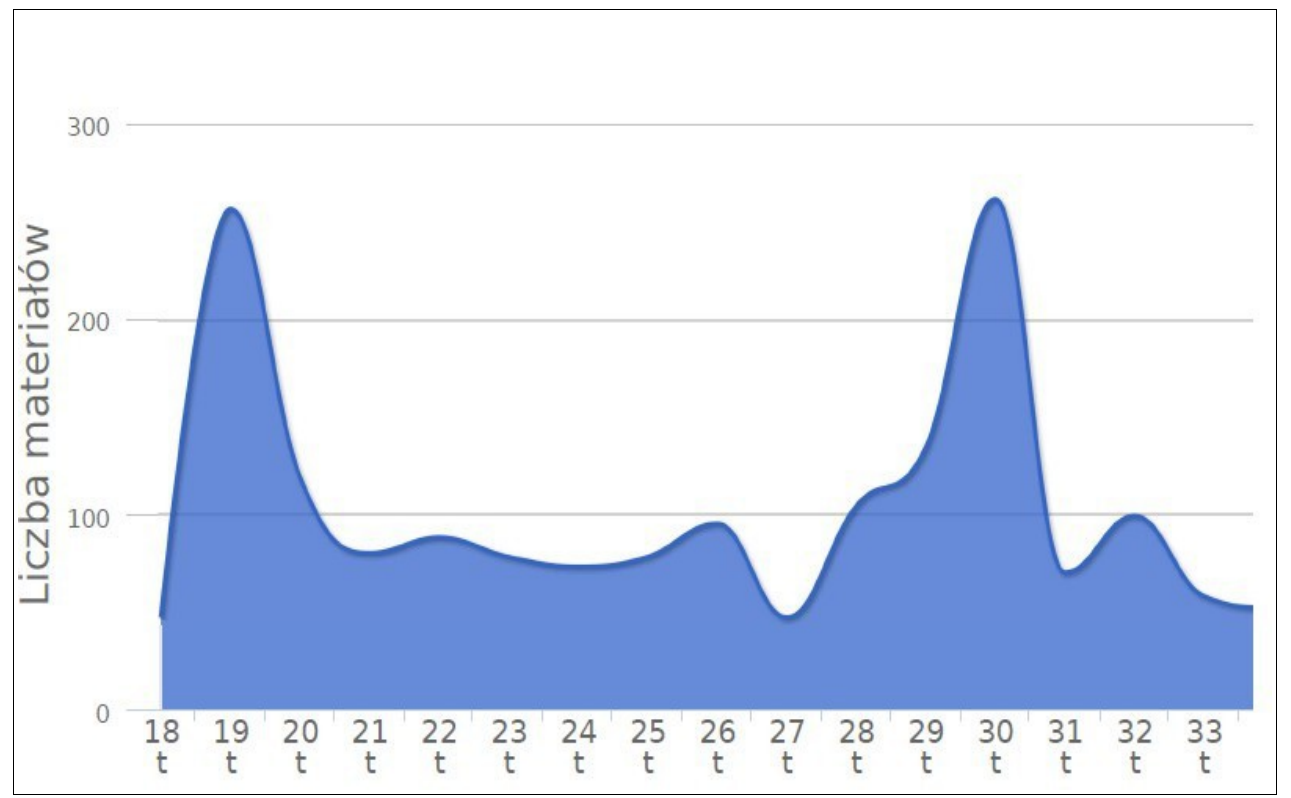

Grafika 7: Rozłożenie w czasie wyników fundacji „Zdążyć z pomocą” (badanie własne/Newspoint.pl) 


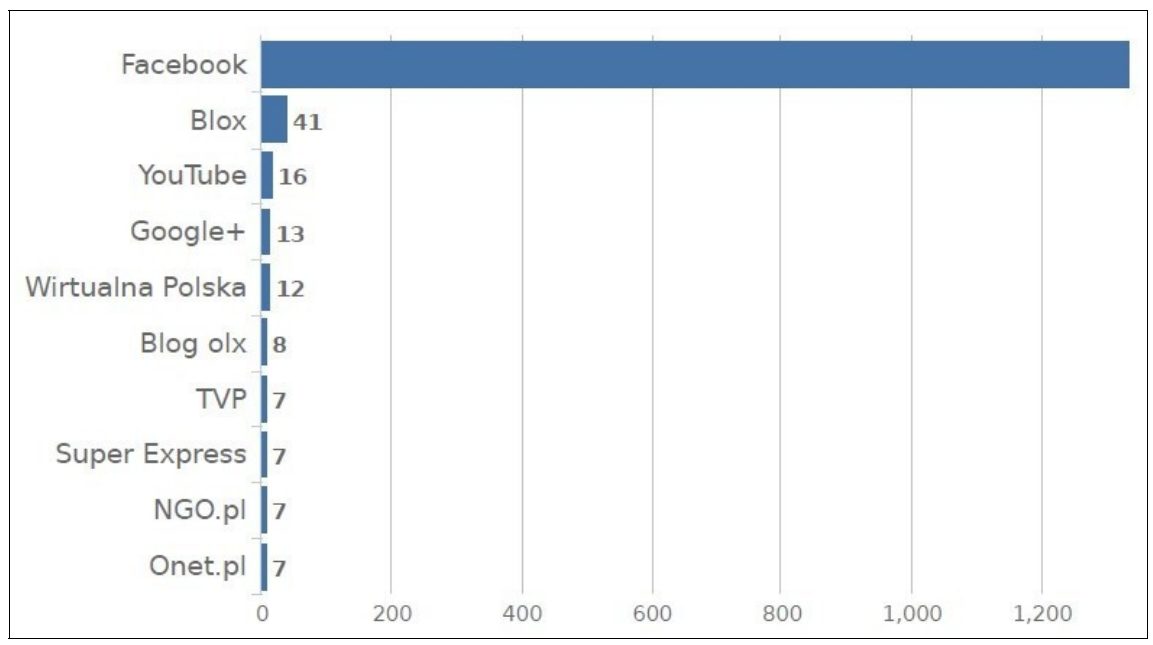

Grafika 8: Serwisy, w których najczęściej dyskutowano o fundacji „Zdążyć z pomocą” (badanie własne/Newspoint.pl)

\section{- Caritas Polska}

W analizowanym półroczu pojawiło się 3109 publikacji dotyczących tej kościelnej organizacji. W odróżnieniu od dwóch wyżej opisanych OPP, najwięcej materiałów ukazało się na stronach www $(52,7 \%)$. Kolejne miejsca to społeczności $(33,7 \%)$, fora internetowe $(5,5 \%)$, mikroblogi $(5,1 \%)$, video $(2,1 \%)$, blogi $(0,6 \%)$ oraz opinie $(0,3 \%)$.

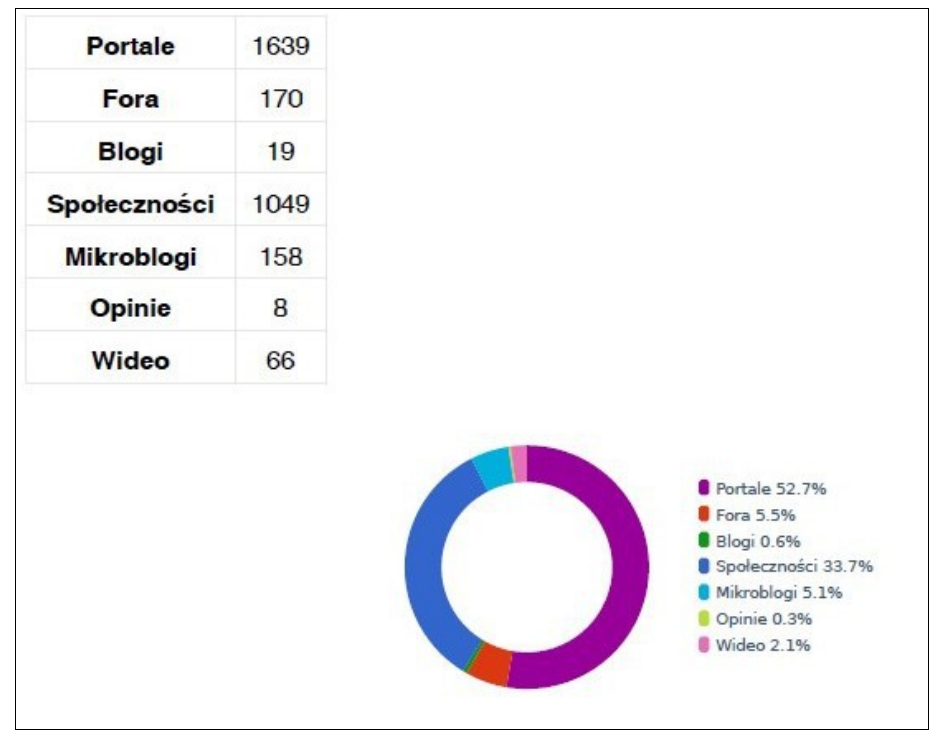

Grafika 9: Wyniki „Caritas” w badanym okresie (badanie własne/Newspoint.pl) 


\section{PUBLIC RELATIONS W INSTYTUCJACH NON-PROFIT}

Monitoring wykazał tyle samo publikacji o wydźwięku negatywnym i pozytywnym. Neutralnych odnotowano 9, zaś nieocenionych w ogóle. Zmiana w stosunku do półrocza poprzedzającego badany okres to wzrost publikacji o pozytywnych o $12,5 \%$ oraz spadek materiałów neutralnych o 87,1\%, negatywnych o 21,7\% (wszystkich - 021 proc.).

\begin{tabular}{|c|c|c|c|c|c|}
\hline \hline & Pozytywne & Neutralne & Negatywne & Nieocenione & Wszystkie \\
\hline $\begin{array}{c}\text { Liczba } \\
\text { wypowiedzi }\end{array}$ & 18 & 9 & 18 & 0 & 45 \\
Zmiana & $12.5 \%$ & $-87.1 \%$ & $-21.7 \%$ & $0.0 \%$ & $-21 \%$ \\
\hline
\end{tabular}

Grafika 10: Wydźwięk publikacji o „Caritas” (badanie własne/Newspoint.pl)

Najwięcej publikacji ukazało się pomiędzy 19. a 20. tygodniem analizowanego półrocza, zaś największy spadek nastąpił ok. 26. tygodnia. Liczba materiałów rozkładała się dość równomiernie. Wśród portali, na których najczęściej podejmowano dyskusję, pierwsze miejsce zajął Facebook. Na kolejnych pozycjach znalazły się Twitter, Ekai.pl, Tygodnik Idziemy, Tygodnik Katolicki Niedziela, YouTube, Wiara.pl, Stooq oraz Deon.pl.

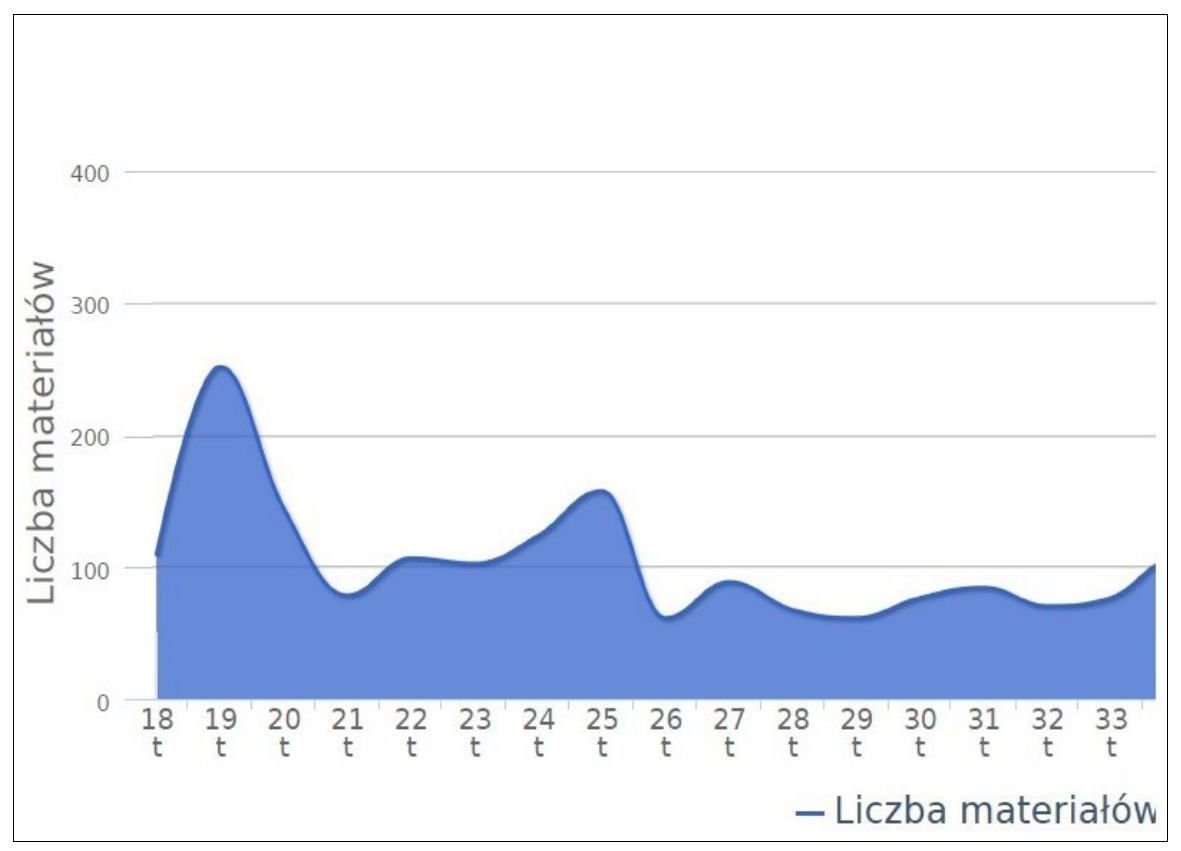

Grafika 11: Rozłożenie w czasie wyników „Caritas” (badanie własne/Newspoint.pl) 


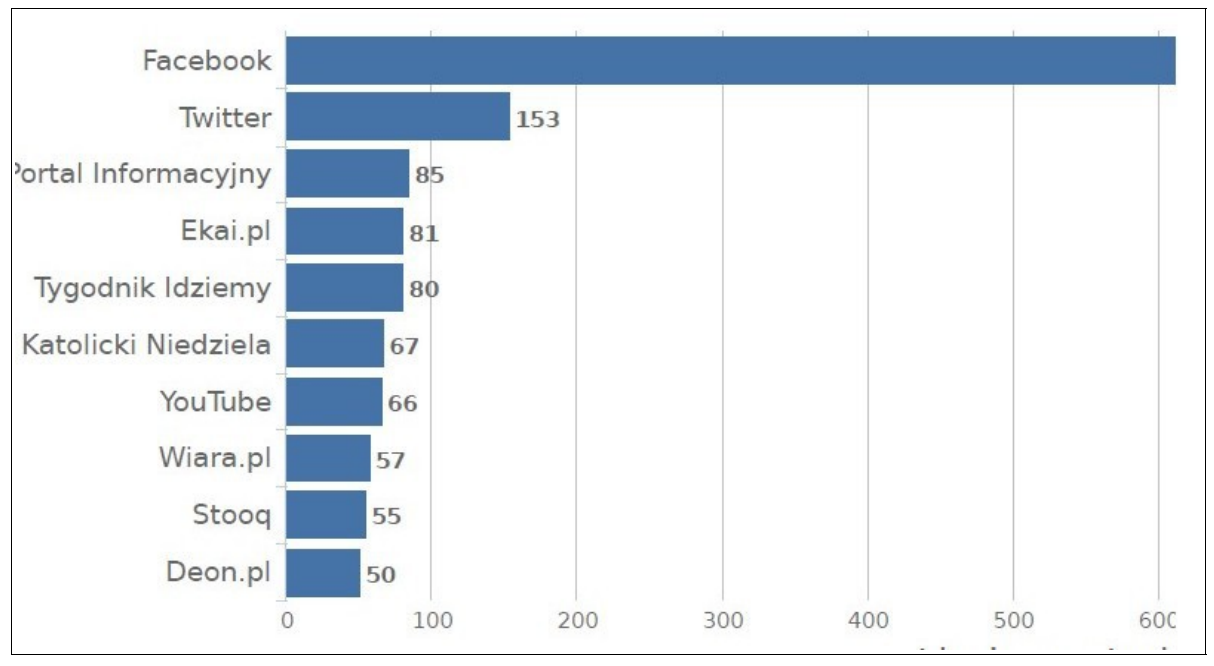

Grafika 12: Serwisy, w których najczęściej dyskutowano o „Caritas” (badanie własne/Newspoint.pl)

- Fundacja „Dzieło Nowego Tysiąclecia”

Fundacja chętnie komunikuje się za pośrednictwem nowoczesnych kanałów, o czym świadczą wyniki monitoringu. W mediach internetowych ukazało się 1091 publikacji, z których większość opublikowano w serwisach społecznościowych $(55,5 \%)$ oraz na stronach www (39\%). Pozostałe wyniki dotyczą mikroblogów $(2,1 \%)$, video $(1,6 \%$ ), forów (1,3\%) oraz opinii i blogów (po $0,3 \%$ ).

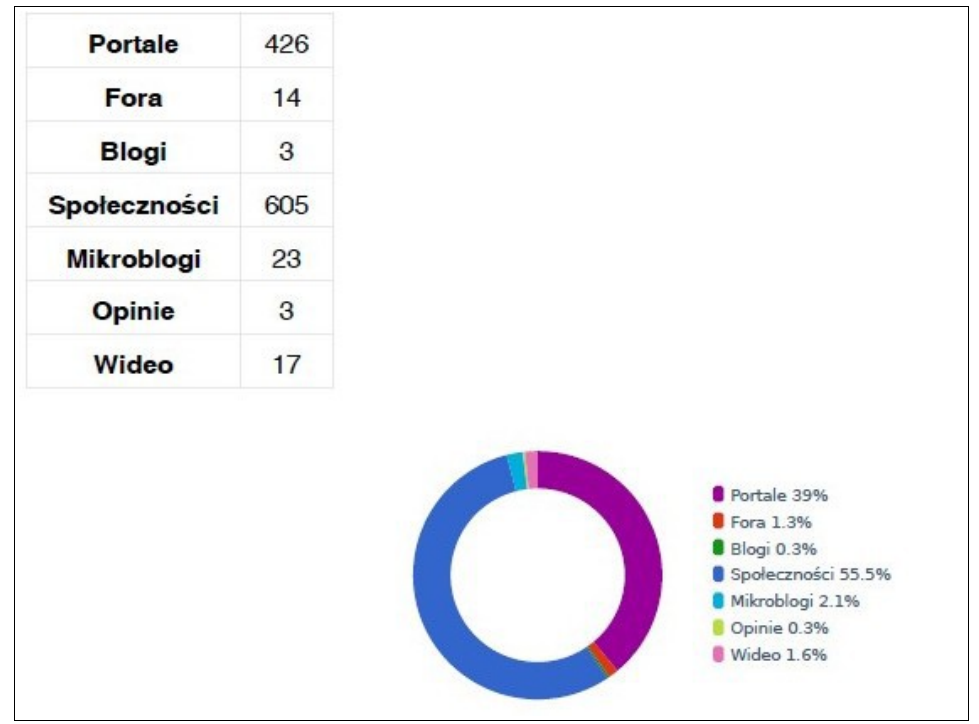

Grafika 13: Wyniki „DNT” w badanym okresie (badanie własne/Newspoint.pl) 


\section{PUBLIC RELATIONS W INSTYTUCJACH NON-PROFIT}

Są to przeważnie materiały o wydźwięku pozytywnym (809). Publikacji neutralnych odnotowano 238, negatywnych - 1 . Zmiana, która nastąpiła w liczbie i wydźwięku materiałów w stosunku do wcześniejszego półrocza, wyniosła wzrost publikacji pozytywnych o $163,5 \%$, neutralnych o $51,6 \%$, zaś nieocenionych o $290,9 \%$. Negatywnych wypowiedzi ubyło o $66,7 \%$. Ogółem liczba materiałów wzrosła o $144 \%$.

\begin{tabular}{|c|c|c|c|c|c|}
\hline & Pozytywne & Neutralne & Negatywne & Nieocenione & Wszystkie \\
\hline $\begin{array}{c}\text { Liczba } \\
\text { wypowiedzi }\end{array}$ & 809 & 238 & 1 & 43 & 1091 \\
\hline Zmiana & $163.5 \%$ & $51.6 \%$ & $-66.7 \%$ & $290.9 \%$ & $144 \%$ \\
\hline
\end{tabular}

Grafika 14: Wydźwięk publikacji o „DNT” (badanie własne/Newspoint.pl)

Publikacje publikacje ukazywały się nieregularnie. Widać wyraźny skok ok. 30. tygodnia, co może być związane z obchodzonym w tym czasie Dniem Papieskim. Największa liczba publikacji ukazała się na Facebooku. Pozostałe miejsca to: Ekai.pl, Tygodnik Idziemy, Tygodnik Katolicki Niedziela, TVP, Twitter, YouTube, Polskie Radio, Deon.pl, Wiara.pl.

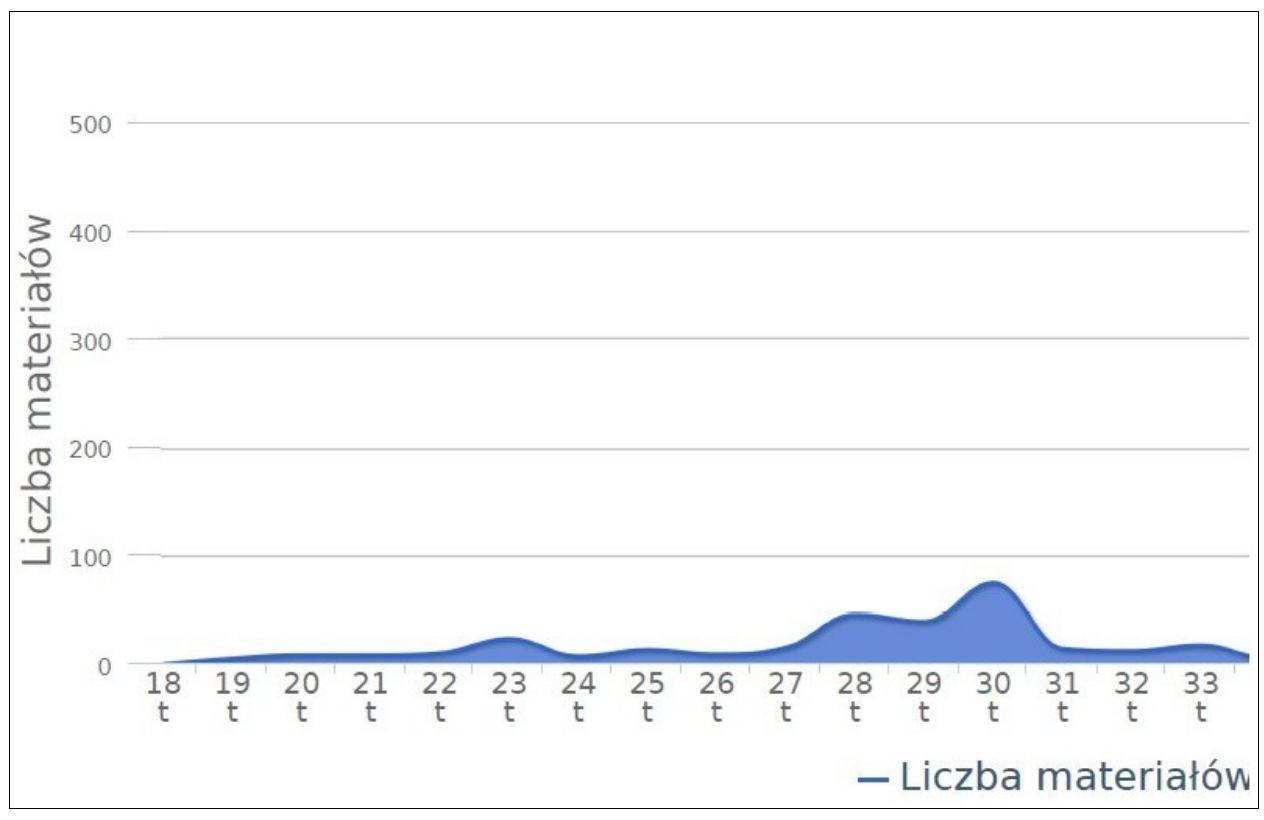

Grafika 15: Rozłożenie w czasie publikacji o „DNT” (badanie własne/Newspoint.pl) 


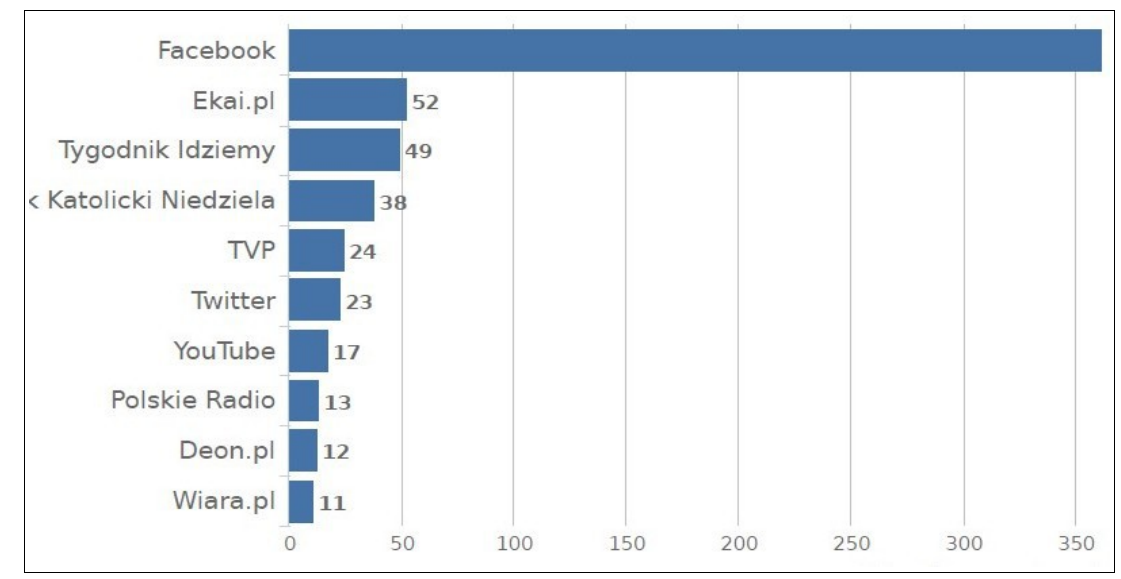

Grafika 16: Serwisy, w których najczęściej dyskutowano o „DNT” (badanie własne/Newspoint.pl)

\section{- Szlachetna Paczka}

Pisząc o komunikacji OPP w social media trudno pominąć Szlachetną Paczkę, która prezentuje wzorcową politykę obecności w serwisach społecznościowych. Liczba wyników uzyskanych w raporcie (473) może nie oddawać w pełni aktywności organizacji. W badaniu zostały uwzględnione tylko te publikacje, które prócz słów kluczowych „Szlachetna Paczka”, zawierały imię i nazwisko inicjatora projektu, czyli ks. Jacka Stryczka, co mogło wpłynąć na zmniejszenie wyników.

Materiały ukazywały się w mediach społecznościowych (52\%) oraz na stronach www $(41,2 \%)$. Kolejne typy serwisów to: fora internetowe $(3,4 \%)$, blogi $(1,7 \%)$, video $(1,1 \%)$ oraz mikroblogi $(0,6 \%)$.

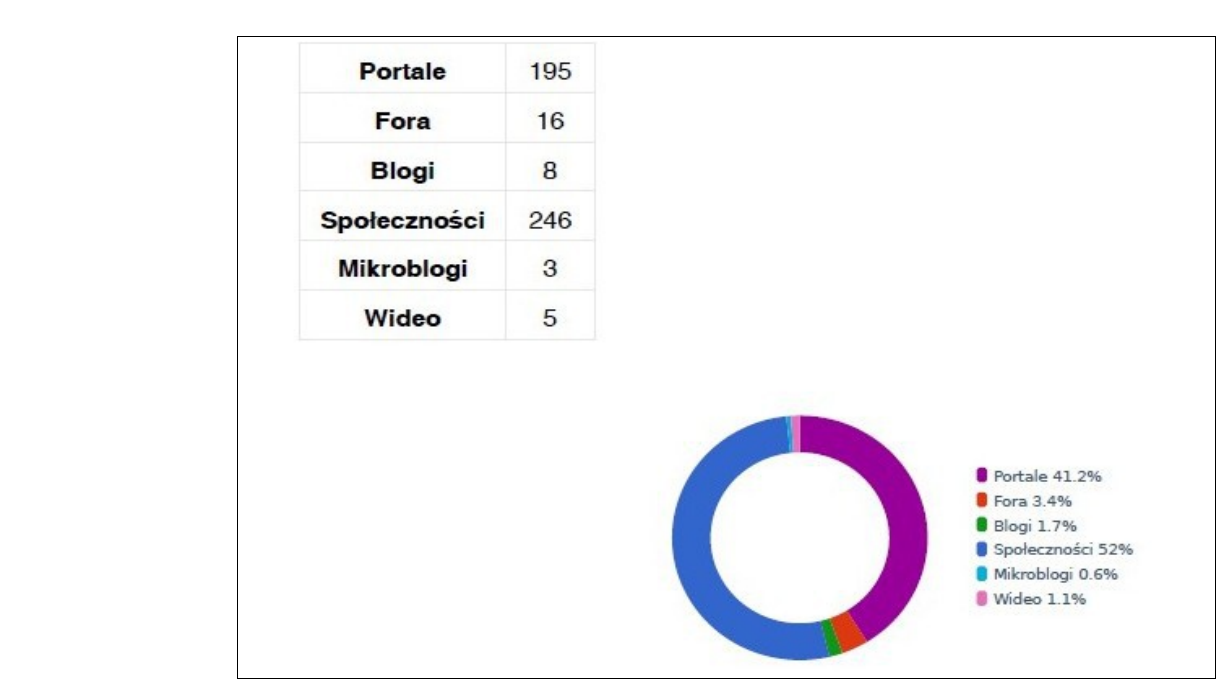

Grafika 17: Serwisy, w których najczęściej dyskutowano o „Szlachetnej Paczce” (badanie własne/Newspoint.pl) 


\section{PUBLIC RELATIONS W INSTYTUCJACH NON-PROFIT}

Najwięcej publikacji (237) oceniono jako neutralne. Wydźwięk pozytywny posiada 135 publikacji, zaś negatywny - 101. Zmiana, która nastąpiła w stosunku do półrocza poprzedzającego badany okres, to spadek wszystkich publikacji o 32\%. Materiałów pozytywnych ubyło o 42,8\%, neutralnych o $61,7 \%$. Liczba postów negatywnych wzrosła o 50,7\%.

\begin{tabular}{|c|c|c|c|c|c|}
\hline & Pozytywne & Neutralne & Negatywne & Nieocenione & Wszystkie \\
\hline $\begin{array}{c}\text { Liczba } \\
\text { wypowiedzi }\end{array}$ & 135 & 237 & 101 & 0 & 473 \\
\hline Zmiana & $-42.8 \%$ & $-61.7 \%$ & $50.7 \%$ & $0.0 \%$ & $-32 \%$ \\
\hline
\end{tabular}

Grafika 18: Wydźwięk publikacji o „Szlachetnej Paczce” (badanie własne/Newspoint.pl)

Największe spadki publikacji zaobserwowano ok. 28. i 32. tygodnia, natomiast skoki pomiędzy 21. a 27. tygodniem. Jeśli chodzi o serwisy, w których najczęściej pojawiały się wzmianki, pierwsze miejsce zajął Facebook. Kolejne pozycje to: Wirtualna Polska, Deon.pl, YouTube, Blog olx, Tygodnik Podhalański, Wiara.pl, Onet.pl oraz Dziennik.pl.

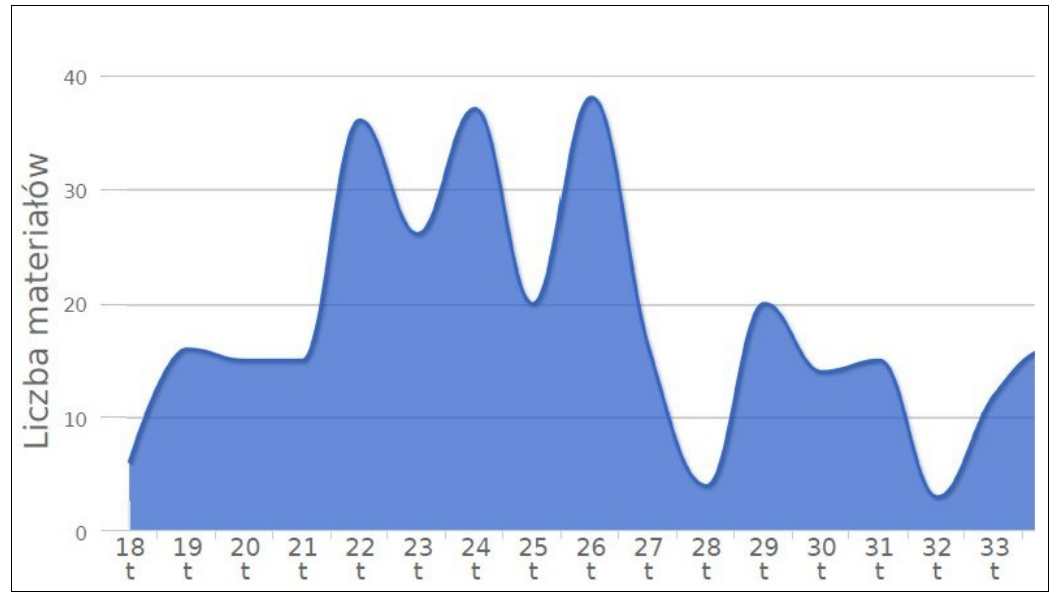

Grafika 19: Rozłożenie w czasie publikacji o „Szlachetnej Paczce” (badanie własne/Newspoint.pl)

\section{Porównanie wyników, wnioski}

Z miesięcznego zestawienia badanych OPP wynika, że fundacje odnotowują wzrosty i spadki publikacji w określonych przedziałach czasowych. Najbardziej równomiernie prezentują się wyniki Caritas Polska - liczba materiałów w każdym miesiącu nie jest mniejsza, niż 250. We wrześniu odnotowano nagły wzrost, co mogło być związane z zaangażowaniem Caritas w pomoc dla migrantów i uchodźców ${ }^{6}$ oraz podsumowaniem lokalnych akcji w diecezjach, w ramach których zbierano fundusze na szkolne wyprawki dla dzieci.

\footnotetext{
${ }^{6}$ Caritas Polska, Komunikat Caritas Polska w sprawie działań na rzecz uchodźców, http://www.caritas.pl/komunikat-caritas-polska-w-sprawie-dzialan-na-rzecz-uchodzcow/, (dostęp: 28.12.2017 r.).
} 


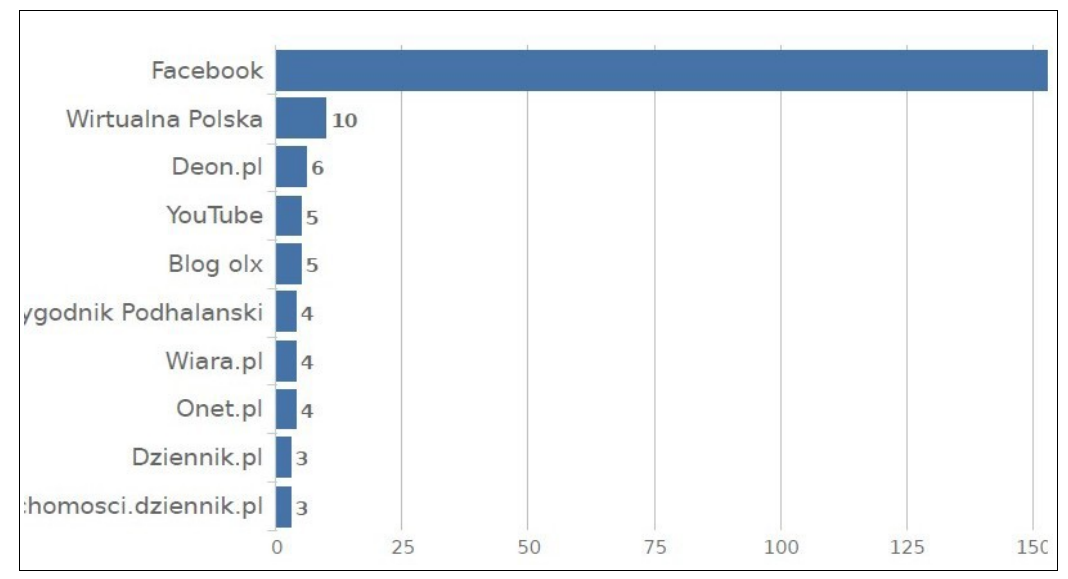

Grafika 20: Serwisy, w których najczęściej dyskutowano o „Szlachetnej Paczce” (badanie własne/Newspoint.pl)

Równomiernie rozkładają się też wyniki fundacji Anny Dymnej - pomiędzy 250 a 500. Największe spadki odnotowano w czerwcu i sierpniu. W sezonie letnim da się jednak zaobserwować ogólny spadek liczby materiałów dotyczących wszystkich analizowanych OPP, co jest najprawdopodobniej związane z wakacjami.

Nieregularnie wyglądają wyniki „DNT” - od maja do sierpnia ukazuje się niewiele materiałów, natomiast gwałtowny wzrost przypada na październik. Jest to związane z Dniem Papieskim - kulminacją działań fundacji. Z tej okazji odbywa się wiele imprez chętnie opisywanych w mediach, nie tylko katolickich. W październiku przyznawane są również stypendia dla zdolnej młodzieży z ubogich rodzin.

Liczba materiałów odnośnie do Szlachetnej Paczki jest w badanym okresie znikoma, co wynika z faktu, że inicjatywa odbywa się w grudniu - podarunki dla potrzebujących są rozdawane przed świętami Bożego Narodzenia. W raporcie zastosowano ponadto zbyt szczegółowe słowa kluczowe (imię i nazwisko ks. Jacka Stryczka), co zaniżyło wyniki.

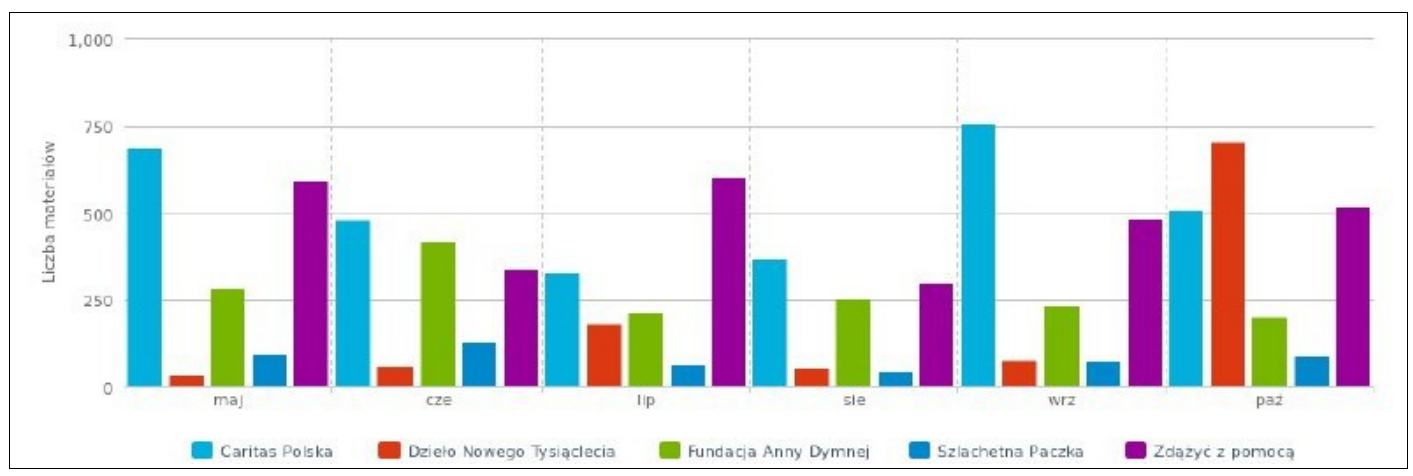

Grafika 21: Porównanie wyników wszystkich fundacji (badanie własne/Newspoint.pl) 
Serwisem, w którym najchętniej dyskutowano o wybranych OPP był Facebook (ponad 5 tys. publikacji), co potwierdza tezę, że dobroczynność jest zagadnieniem często pojawiającym się w mediach społecznościowych. Znaczna przewaga Facebooka nad innymi portalami może wynikać z metody zliczania wyników, która uwzględnia nie tylko posty (statusy), ale również komentarze zawierające słowa kluczowe. Nie zaburza to jednak znacząco ogólnego wyniku, ponieważ użytkownik Facebooka może określić zasięg wpisów ograniczając widoczność do grona znajomych, a posty prywatne nie są uwzględniane w zestawieniu. Ponadto, jeśli zastosowana metoda uwzględnia nie tylko artykuły na stronach www, ale również komentarze internautów, pojawią się one w ogólnym zestawieniu, równoważąc wysokie wyniki z social media.

O przewadze mediów społecznościowych w dyskusji na temat OPP decyduje również 2. miejsce, na którym znalazł się Twitter oraz zamykający pierwszą piątkę YouTube. Pozostałe portale przodujące w zestawieniu to serwisy katolickich czasopism oraz religijne portale, jak Ekai.pl, Deon.pl, Wiara.pl, Opoka, witryna tygodnika „Niedziela”, „Idziemy” czy „Gościa Niedzielnego”. W raporcie pojawiają się również ogólnopolskie media informacyjne, jak TVN24 czy Polskie Radio.

\section{Wybrane narzędzia social media a promocja działań organizacji non profit}

Obecność w social media jest niezbędnym elementem polityki medialnej OPP. Komunikaty w mediach tradycyjnych oraz internetowych to sposób dotarcia do odbiorców i promowania dobroczynności, a także pozyskiwania środków. O potędze mediów społecznościowych świadczą rosnące liczby użytkowników - na samym Facebooku konto posiada 14 milionów polskich internautów ${ }^{7}$. Spędzają oni w internecie i mediach społecznościowych średnio 4,4 godziny (desktop) i 1,3 godziny (mobile) każdego dnia ${ }^{8}$.

Media społecznościowe służą wzmocnieniu przekazów wysyłanych za pośrednictwem tradycyjnych kanałów komunikacji. Warto zastanowić się nad tym, jak umiejętnie korzystać z wybranych narzędzi social media, aby zwiększyć skuteczność OPP. Prezentując poszczególne narzędzia (zaczynając od czynności najprostszych i stopniowo przechodząc do bardziej zaawansowanych aktywności), podaję przykłady działań wybranych fundacji.

- Szybkie odpisywanie na wiadomości (także z katalogu „Inne”, jak w przypadku Facebooka) jest podstawą w mediach społecznościowych. Służy to budowaniu relacji pomiędzy użytkownikami i usprawnia komunikację ${ }^{9}$. Fanpage'e zawierają informację (lewy górny róg strony) o tym, jak szybko dany podmiot odpisuje na wiadomości (dla przykładu - Caritas Polska robi to „bardzo sprawnie”).

\footnotetext{
${ }^{7}$ Ł. Dębski, Statystyki Facebooka w Polsce. Stan na 08.2016, http://www.infosocialmedia.pl/statystykifacebooka-w-polsce-2q-2016/, (dostęp: 09.12.2017 r.).

${ }^{8}$ M. Gwóźdź, Liczby polskiego internetu 2016, http://zblogowani.pl/wpis/2023462/liczby-polskiegointernetu-2016, (dostęp: 09.12.2017 r.).

${ }^{9}$ Zob. M. Pełechaty, Społeczności internetowe, w: K. Pankiewicz (red.), E-marketing w akcji, Gliwice 2008, s. 151,165 .
} 
M. Brzezińska-Waleszczyk, Jak zwiększyć skuteczność organizacji non profit...

\begin{tabular}{|c|c|c|c|c|c|c|c|}
\hline 类 & 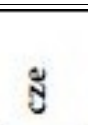 & $\cong$ & $\frac{\oplus}{\infty}$ & $\frac{N}{3}$ & 式 & & 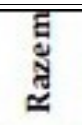 \\
\hline Wszystkie & 1677 & 1409 & 1369 & 993 & 1605 & 1991 & 9044 \\
\hline Facebook & 1026 & 805 & 897 & 599 & 771 & 1001 & 5099 \\
\hline Twitter & 27 & 36 & 31 & 11 & 41 & 56 & 202 \\
\hline Ekai.pl & 23 & 23 & 8 & 8 & 18 & 56 & 136 \\
\hline Tygodnik Idziemy & 12 & 21 & 14 & 9 & 24 & 51 & 131 \\
\hline YouTube & 15 & 19 & 47 & 24 & 6 & 18 & 129 \\
\hline Tygodnik Katolicki Niedziela & 9 & 16 & 12 & 11 & 22 & 40 & 110 \\
\hline Sądecki Portal Informacyjny & 6 & 2 & 2 & 2 & 76 & 7 & 95 \\
\hline Wiara.pl & 17 & 13 & 6 & 4 & 19 & 17 & 76 \\
\hline Deon.pl & 5 & 11 & 10 & 8 & 18 & 17 & 69 \\
\hline Wirtualna Polska & 6 & 10 & 29 & 8 & 10 & 6 & 69 \\
\hline TVP & 10 & 7 & 8 & 10 & 11 & 21 & 67 \\
\hline Stooq & 12 & 16 & 4 & 6 & 14 & 14 & 66 \\
\hline Polskie Radio & 11 & 10 & 2 & 4 & 9 & 26 & 62 \\
\hline Stooq & 13 & 12 & 4 & 6 & 12 & 12 & 59 \\
\hline Opoka & 6 & 9 & 5 & 4 & 22 & 8 & 54 \\
\hline Onet.pl & 7 & 15 & 7 & 8 & 8 & 9 & 54 \\
\hline Gazeta.pl & 16 & 13 & 6 & 7 & 4 & 7 & 53 \\
\hline Radio Maryja & 16 & 9 & 4 & 6 & 6 & 6 & 47 \\
\hline TVN24 & 8 & 5 & 0 & 1 & 5 & 27 & 46 \\
\hline Blox & 9 & 9 & 6 & 4 & 10 & 7 & 45 \\
\hline Gość Niedzielny & 10 & 6 & 1 & 1 & 13 & 9 & 40 \\
\hline Wosp & 1 & 1 & 21 & 10 & 3 & 0 & 36 \\
\hline Google+ & 6 & 4 & 5 & 5 & 5 & 10 & 35 \\
\hline RMF24 & 23 & 2 & 1 & 0 & 2 & 3 & 31 \\
\hline Polskie Radio PiK & 11 & 9 & 0 & 2 & 3 & 5 & 30 \\
\hline Pozostale & 372 & 326 & 239 & 235 & 473 & 558 & 2203 \\
\hline
\end{tabular}

Grafika 22: Serwisy, w których najczęściej dyskutowano o badanych fundacjach ogółem (badanie własne/Newspoint.pl) 
- Szybkie reagowanie na komentarze użytkowników oraz ich posty (o ile opcja nie została wyłączona przez administratorów) to fundament kształtowania dobrych relacji $\mathrm{z}$ fanami ${ }^{10}$ oraz budowania grupy zaangażowanych użytkowników (najbardziej wartościowych z punktu widzenia organizacji) ${ }^{11}$. Użytkownicy social media chcą, by traktować ich jak ludzi, a nie jak cyferki na liczniku fanów. Chcą, żeby ich słuchać, nie tylko oferować produkt/usługę (tutaj: proponować wpłatę na określone konto) ${ }^{12}$. Kwestią priorytetową w social media jest człowiek i nawiązywanie relacji ${ }^{13}$.

- Zamieszczanie postów zawierających grafikę, zdjęcie, rysunek, mem. Z obserwacji mechanizmów Facebooka wynika, że wpisy z ilustracją są chętniej udostępniane, aniżeli posty tekstowe. Z analizy fanpage'y wybranych fundacji wynika, że prawie w ogóle nie umieszczają one postów wyłącznie tekstowych.

- Regularna publikacja postów to forma podtrzymania kontaktu z odbiorcami. Strony, na których posty ukazują się rzadziej niż raz dziennie/co drugi dzień, są dla użytkowników mało atrakcyjne. Ideałem byłoby zamieszczanie ok. 3 postów dziennie na Facebooku i 5-7 wpisów na Twitterze ${ }^{14}$ (w godzinach, w których użytkownicy są najbardziej aktywni, co można sprawdzić w statystykach strony) Z częstotliwością wpisów należy uważać - spamowanie może skutkować odlajkowaniem strony.

- Publikacja informacji z branży. Prowadząc fanpage nie trzeba się ograniczać do zamieszczania postów dotyczących własnej działalności ${ }^{15}$. Monotematyczność (linki do materiałów ze strony www fundacji) nie zachęci użytkowników do zwiększania wpłat na rzecz OPP. Warto publikować informacje o innych organizacjach non profit, ale również linki do blogów i ciekawych materiałów znalezionych $\mathrm{w}$ sieci $^{16}$. Można też odwołać się do stron o całkiem innym profilu. Dla przykładu na fanpage’u Caritas można znaleźć link do tekstu z Natemat.pl ${ }^{17}$, który bywa uznawany za portal krytykujący Kościół.

\footnotetext{
${ }^{10}$ Zob. J. Gitomer, Społecznościowy boom! Wykorzystaj potencjał sieci e-kontaktów do wykreowania marki, zwiększenia sprzedaży i zdominowania rynku, Gliwice 2012, s. 60-66.

${ }^{11}$ Zaangażowani użytkownicy to internauci, którzy nie tylko dodali fanpage do ulubionych, ale aktywnie reagują na dodawane treści - lajkują, komentują, a przede wszystkim udostępniają posty, przez co zwiększają ich zasięg.

${ }^{12}$ S. Axelrod, Stop Reading About Social Media Trends And Start Listening, http://techcrunch.com/2015/12/22/stop-reading-about-social-media-trends-and-start-listening/, (dostęp: 30.12.2017 r.).

${ }^{13}$ Zob. W. Gustowski, Komunikacja w mediach społecznościowych, Gdynia 2012, s. 47-48.

${ }^{14}$ FaniMani.pl, Jak prowadzić działania na Twitterze - poradnik dla non profit cz.2, https://fanimani.pl/blog/jak-prowadzic-dzialania-na-twitterze-poradnik-dla-non-profit-cz-2/, (dostęp: 30.12.2017 r.).

${ }^{15}$ FaniMani.pl, Jak prowadzić..., dz. cyt.

${ }^{16}$ FaniMani.pl, Jak prowadzić..., dz. cyt.

${ }^{17}$ Screen w posiadaniu Autorki.
} 
- Treści wartościowe dla fanów ${ }^{18}$. Aby wyjść poza komunikację wyłącznie o własnej działalności i sukcesach, ale jednak pozostać w kręgu tematyki dobroczynności, można zamieszczać treści wartościowe z punktu widzenia użytkowników - na przykład wskazówki, jak dokonać odpisu 1\% lub dopełnić kwestii formalnych czy porady, jak skorzystać z pomocy (fundacja „Zdążýc z pomocą” proponowała artykuł o zasadach przyznawania zasiłku stałego ${ }^{19}$ ).

- Ludzkie historie. Aby uniknąć przesadnej autopromocji, warto pisać o ludziach - na przykład, kim są wolontariusze fundacji ${ }^{20}$, dlaczego zaangażowali się w działalność charytatywną, jak praca wpłynęła na ich życie. Ciekawe dla czytelników będą wiadomości o osobach, którym udało się pomóc - krótkie notatki oraz fotografie podopiecznych fundacji, stypendystów, dzieci, którym zakupiono niezbędny do leczenia sprzęt. Tym, co przyciąga uwagę odbiorców każdego medium są tzw. human stories ${ }^{21}$.

- Stosowanie oznaczeń. Dla zwiększenia zasięgu strony warto oznaczać konta osób publicznych czy innych organizacji poprzedzając je znakiem „@” (automatycznie pojawia się odwołanie do witryny ${ }^{22}$. To skuteczny zabieg w przypadku oznaczania dużych fanpage'y, jak papieża Franciszka (180 tys. polubień) czy Agnieszki Radwańskiej (900 tys. polubień). Dla Caritas Polska i Szlachetnej Paczki, które oznaczyły wspomniane fanpage'e w swoich postach, to szansa na zwiększenie zasięgu i zachęcenie followersów papieża i tenisistki do włączenia się w działalność charytatywną. Dobrym sposobem jest zaprzyjaźnienie się ze znanymi blogerami i youtuberami, czyli osobami popularnymi w social media. Zaproszenie ich do bycia ambasadorami projektu albo choćby sfotografowanie się z nimi (z oznaczeniem ich kont przez „@”), to kolejny sposób na dotarcie do nowych użytkowników ${ }^{23}$.

- Dziękowanie. Do podstaw społecznościowego savoir vivre’u należy dziękowanie za udostępnienia postu i retweety ${ }^{24}$. Ideałem byłoby podziękowanie krótkim postem lub emotikoną każdemu użytkownikowi, ale w przypadku dużej liczby fanów może to być trudne. Warto natomiast przyjąć zasadę dziękowania za wpisy, w których oznaczono fundację. Tym bardziej, jeśli są to posty znanych osób (Krzysztof Ziemiec o Caritas Polska czy Paweł Tkaczyk o fundacji

\footnotetext{
${ }^{18}$ Zob. J. Falls, E. Deckers, Media społecznościowe bez ściemy. Jak kreować markę, Gliwice 2013, s. 133-152.

${ }^{19}$ Screen w posiadaniu Autorki.

${ }^{20}$ Stowarzyszenie Wiosna z okazji 15-lecia Szlachetnej Paczki przygotowało film nt. pracowników fundacji; https://www.youtube.com/watch?v=yVoyW2UlGac, (dostęp: 30.12.2017 r.).

${ }^{21}$ Zob. M. Sadowski, Rewolucja social media, Gliwice 2013, s. 89-105.

${ }^{22}$ FaniMani.pl, Jak prowadzić działania na Twitterze - poradnik dla non profit cz.1, https://fanimani.pl/ blog/jak-prowadzic-dzialania-na-twitterze-poradnik-dla-non-profit-cz-1/, (dostęp: 30.12.2017 r.).

${ }^{23}$ Fundacja Dzieciom „Zdążyć z pomocą” skorzystała z pomocy JDabrowsky, znanego youtubera, który włączył się w jedną z akcji charytatywnych.

${ }^{24}$ FaniMani.pl, Jak prowadzić..., dz. cyt.
} 
Anny Dymnej ${ }^{25}$. Dziękować należy także tym, którzy włączają się w projekty fundacji czy promocję jej działań (dotyczy to także mediów). Można podlinkować artykuł na stronie fundacji oznaczając redakcję przez „@”. Niepisanym zwyczajem w social media jest zasada wzajemności, w ramach której obserwuje się/lubi fanpage/konto osoby, która dołączyła do grona followersów/użytkowników fundacji.

- Skracanie linków jest jedną z fundamentalnych zasad w mediach społecznościowych. Można to zrobić korzystając ze specjalnych serwisów (np. Bitly.com), zaś na Facebooku usunąć je całkowicie pozostawiając okno ze zdjęciem i leadem tekstu odsyłającym bezpośrednio do artykułu ${ }^{26}$.

- Używanie hashtagów jest kolejnym sposobem zwiększenia zasięgu odbiorców. Wpisywanie słów poprzedzonych znakiem „\#” można wykorzystać zarówno na Facebooku, jak i na Twitterze (ułatwia wyszukiwanie treści). Hashtagi służą ponadto skróceniu postów (kilka tagów zamiast pełnych zdań). Najcenniejsze jest tworzenie własnych hashtagów, zwłaszcza w przypadku kampanii społecznych, akcji czy projektów z atrakcyjną nazwą własną ${ }^{27}$. Za przykład może posłużyć akcja Caritas Polska pod hasłem „Tornister pełen uśmiechów”.

- Dobrą praktyką jest nawiązywanie do aktualnych wydarzeń. W social media wszystko dzieje się bardzo szybko, dlatego administratorzy fanpage'a powinni działać na bieżąco. Aktualne wydarzenia można wykorzystać w kontekście zbierania funduszy na rzecz $\mathrm{OPP}^{28}$. Aby być na bieżąco, należy śledzić to, co w danym momencie absorbuje uwagę użytkowników social media. Włączanie się w trwającą na Twitterze dyskusję ułatwia obserwowanie trendów (lewy górny róg).

- Warto zadbać o maksymalne uproszczenie mechanizmu przekazywania datków na fundację, także z wykorzystaniem social media. Nie chodzi tylko o odsyłanie do stron www, gdzie dokonuje się odpisu $1 \%$, ale o tworzenie aplikacji, za pośrednictwem których można dokonać wpłaty ${ }^{29}$.

- W mediach społecznościowych sprawdza się poczucie humoru i dystans ${ }^{30}$. Używanie emotikon nie zmniejsza powagi OPP, a zdecydowanie skraca posty (co szczególnie ważne na Twitterze) ${ }^{31}$. Wpisy z ikonami bardziej angażują użyt-

\footnotetext{
${ }^{25}$ Screen w posiadaniu Autorki.

${ }^{26}$ FaniMani.pl, Jak prowadzić..., dz. cyt.

${ }^{27}$ FaniMani.pl, Jak prowadzić..., dz. cyt.

${ }^{28}$ Z okazji 11 listopada Fundacja Anny Dymnej zachęcała do zakupu rogali świętomarcińskich. Dochód z ich sprzedaży dzięki Charytatywni.Allegro został przekazany na rzecz podopiecznych organizacji.

${ }^{29}$ Nowoczesne rozwiązania w kwestii wpłat na rzecz fundacji, korzystając z social media stosuje np. Caritas Polska oraz Fundacja Anny Dymnej.

${ }^{30}$ J.C. Levinson, S. Gibson, Marketing partyzancki w mediach społecznościowych. 126 narzędzi w walce o pozycję w internecie, Warszawa 2013, s. 58-62.

${ }^{31}$ FaniMani.pl, Jak prowadzić..., dz. cyt.
} 
kowników. Podobnie jest w przypadku żartobliwych postów, zwłaszcza pokazujących dystans do siebie ${ }^{32}$. Można żartować, jednak nie warto publikować wpisów zbyt osobistych, które mogłyby znaleźć się na prywatnym koncie, ale nie oficjalnym fanpage'u.

Aktywność w social media wymaga od fundacja przemyślanej i długofalowej strategii, która składa się na całościową politykę komunikacji medialnej ${ }^{33}$. Warto być obecnym w różnych kanałach społecznościowych, gdyż zwiększa to szanse na dotarcie do nowych odbiorców. Konta w kanałach społecznościowych powinny być zsynchronizowane ${ }^{34}$, ale raczej należy unikać multiplikowania treści. Może to świadczyć o braku kreatywności administratorów, a odbiorców nudzić. Profilu na Twitterze nie należy łączyć z Facebookiem tak, by na tablicy automatycznie pojawiały się adnotacje o nowych aktualizacjach. Można natomiast korzystać z wtyczek na stronie www, które ułatwią szybkie polecenie tekstu w mediach społecznościowych oraz z aplikacji Click to tweet, aby bezpośrednio zamieszczać na Twitterze cytaty z wpisów na blogu czy stronie $w w w^{35}$.

\section{Wnioski, propozycje}

Media społecznościowe są ważnym elementem polityki medialnej organizacji non profit. Aktywność w social media jest stosunkowo tanim (w porównaniu z wykupieniem reklamy w tradycyjnych mediach), a więc łatwo dostępnym dla niewielkiej organizacji ${ }^{36}$, sposobem budowania szerokiego zasięgu. Za pośrednictwem serwisów społecznościowych można wzmacniać przekaz generowany w tradycyjnych kanałach.

Aby komunikacja w mediach społecznościowych przekładała się na zwiększanie skuteczności OPP, powinna spełniać kilkanaście warunków, które w skrócie można opisać jako umiejętne, rozsądne i przemyślane korzystanie z narzędzi poszczególnych serwisów.

Podsumowując, warto zaproponować, aby administracją kanałów społecznościowych fundacji zajmowała się osoba (grupa osób) dedykowana wyłącznie temu zadaniu. Aktualizowanie kont w social media to praca $7 \mathrm{dni}$ w tygodniu, 24 godziny na dobę - Facebooka nie da się wyłączyć o godz. 16 i wyjść z biura. Niestety, jak pokazują badania, w wielu firmach nadal powszechną praktyką jest zlecanie administracji kont społecznościowych w ramach dodatkowych obowiązków pracowników ${ }^{37}$, co oznacza

\footnotetext{
${ }^{32}$ Szlachetna Paczka zamieszcza np. grafikę z popularną postacią z filmu Star Wars, który nosi logi fundacji albo żarty (poprzedzając je \#suchartime); screeny w posiadaniu Autorki.

${ }^{33}$ Zob. A. Miotk, Skuteczne social media, Gliwice 2013, s. 62-70.

${ }^{34}$ Zob. A. Podlaski, Marketing społecznościowy. Tajniki skutecznej promocji w social media, Gliwice 2011, s. 81-82.

${ }^{35}$ FaniMani.pl, Jak prowadzić działania na Twitterze - poradnik dla non profit cz.3, https://fanimani.pl/blog/jak-prowadzic-dzialania-na-twitterze-poradnik-dla-non-profit-cz-3/, (dostęp: 30.12.2017 r.).

${ }^{36}$ Zob. J. Lipski, Marketing małej firmy w mediach społecznościowych - jak podejść do niego strategicznie, w: „Marketer+” 4/2017, s. 30-33.

${ }^{37}$ Deloitte, Biznes społecznościowy - nowa era w komunikacji biznesowej. Raport na podstawie badania
} 


\section{PUBLIC RELATIONS W INSTYTUCJACH NON-PROFIT}

brak jednoznacznej odpowiedzialności za dodawane treści ${ }^{38}$. Ważne jest ponadto dokonywanie systematycznych pomiarów i optymalizowanie komunikacji, by osiągać lepsze efekty ${ }^{39}$. Korzystanie z pomocy profesjonalistów w dziedzinie komunikacji w social media jest szansą na zwiększenie skuteczności organizacji ${ }^{40}$.

\section{BIBLIOGRAFIA:}

Axelrod S., Stop Reading About Social Media Trends And Start Listening, http://techcrunch.com/2015/12/22/stop-reading-about-social-mediatrends-and-start-listening/.

Brzezińska-Waleszczyk M., Dobre praktyki praktyki w komunikacji marek w mediach społecznościowych, „Studia Medioznawcze” 4/2015, s. 67-78.

Caritas Polska, Komunikat Caritas Polska w sprawie działań na rzecz uchodźców, http://www.caritas.pl/komunikat-caritas-polska-w-sprawie-dzialanna-rzecz-uchodzcow/.

Deloitte, Biznes społecznościowy - nowa era w komunikacji biznesowej. Raport na podstawie badania „Polskie firmy na Facebooku - portale społecznościowe w komunikacji marketingowej polskich przedsiębiorstw", https://marketingowe.files.wordpress.com/2013/10/raport-biznes-spolecznosciowy.pdf.

Dębski Ł., Statystki Facebooka w Polsce. Stan na 08.2016, http://www.infosocialmedia.pl/statystyki-facebooka-w-polsce-2q-2016/.

Falls J., Deckers E., Media społecznościowe bez ściemy. Jak kreować markę, Gliwice 2013.

FaniMani.pl, Jak prowadzić działania na Twitterze - poradnik dla non profit $c z .2$, https://fanimani.pl/blog/jak-prowadzic-dzialania-na-twitterze-poradnik-dla-non-profit-cz-2/.

FaniMani.pl, Jak prowadzić działania na Twitterze - poradnik dla non profit cz.1, https://fanimani.pl/blog/jak-prowadzic-dzialania-na-twitterze-poradnik-dla-non-profit-cz-1/.

FaniMani.pl, Jak prowadzić działania na Twitterze - poradnik dla non profit $c z .3$, https://fanimani.pl/blog/jak-prowadzic-dzialania-na-twitterze-poradnik-dla-non-profit-cz-3/.

Gitomer J., Społecznościowy boom! Wykorzystaj potencjał sieci e-kontaktów do wykreowania marki, zwiększenia sprzedaży i zdominowania rynku, Gliwice 2012.

\footnotetext{
„Polskie firmy na Facebooku - portale społecznościowe $w$ komunikacji marketingowej polskich przedsiębiorstw”, https://marketingowe.files.wordpress.com/2013/10/raport-biznes-spolecznosciowy.pdf, (dostęp: 30.12.2017 r.).

${ }^{38}$ Zob. M. Brzezińska-Waleszczyk, Dobre praktyki praktyki w komunikacji marek w mediach społecznościowych, w: Studia Medioznawcze 4/2015, s. 69-70.

${ }^{39}$ Zob. J. Lovett, Sekrety pomiarów w mediach społecznościowych, Gliwice 2012, s. 231-262.

${ }^{40}$ Zob. A. Miotk, Nowy PR. Jak internet zmienił public relations, Lublin 2016, s. $238-265$.
} 
Gustowski W., Komunikacja w mediach społecznościowych, Gdynia 2012.

Gwóźdź M., Liczby polskiego internetu 2015, http://smmeasure.eu/liczby-polskiego-internetu-2015/.

Gwóźdź M., Liczby polskiego internetu 2016, http://zblogowani.pl/wpis/2023462/liczby-polskiego-internetu-2016.

Levinson J.C., Gibson S., Marketing partyzancki w mediach społecznościowych. 126 narzędzi $w$ walce o pozycję w internecie, Warszawa 2013.

LK/Warszawa/KAI, 44 proc. Polaków wsparło organizacje pożytku publicznego, http://www.niedziela.pl/artykul/6526/44-proc-Polakow-wsparlo-organizacje.

Lovett J., Sekrety pomiarów w mediach społecznościowych, Gliwice 2012.

Marchwicki M., Szlachetna Paczka bije rekordy na Facebooku, http://socialpress.pl/2014/12/szlachetna-paczka-bije-rekordy-na-facebooku/.

Ministerstwo Finansów, Informacja dotycząca kwot 1\% należnego podatku dochodowego od osób fizycznych przekazanych organizacjom pożytku publicznego z rozliczenia za 2013 rok, http://www.finanse.mf.gov.pl/documents/766655/2970107/Wykaz+organizacji+po\%C5\%BCytku+publicznego $\% 2 \mathrm{C}+\mathrm{kt} \% \mathrm{C} 3 \% \mathrm{~B} 3 \mathrm{re}+\mathrm{w}+2014+\mathrm{r}$.+otrzyma\% $\% 5 \% 82 \mathrm{y}+1+$ proc.

Ministerstwo Finansów, Informacja dotycząca kwot 1\% należnego podatku dochodowego od osób fizycznych przekazanych organizacjom pożytku publicznego z rozliczenia za 2014 rok, http://www.finanse.mf.gov.pl/documents/766655/5008832/Wykaz+organizacji+po\%C5\%BCytku+publicznego $\% 2 \mathrm{C}+\mathrm{kt} \% \mathrm{C} 3 \% \mathrm{~B} 3 \mathrm{re}+\mathrm{w}+2015+$ otrzyma\% $\mathrm{C} 5 \% 82 \mathrm{y}+\mathrm{kwoty}+1+$ proc.

Miotk A., Nowy PR. Jak internet zmienił public relations, Lublin 2016, s. 238265

Miotk A., Skuteczne social media, Gliwice 2013.

Pełechaty M., Społeczności internetowe, w: Pankiewicz K. (red.), E-marketing w akcji, Gliwice 2008, s. 151-165.

Podlaski A., Marketing społecznościowy. Tajniki skutecznej promocji w social media, Gliwice 2011.

Sadowski M., Rewolucja social media, Gliwice 2013.

\section{O AUTORCE:}

Mgr lic. Marta Brzezińska-Waleszczyk, Przygotowuje rozprawę doktorską o nowej ewangelizacji w social media (planowana obrona - styczeń 2018). Dziennikarka i publicystka. Wspólpracowała m.in. z Rzeczpospolitą, Deon.pl, Przewodnikiem Katolickim, Natemat.pl oraz Wirtualną Polską. Obecnie szef działu Kultura w polskiej edycji międzynarodowego serwisu Aleteia. Kontakt: mart.bre@gmail.com 
кuLTura- MeDia-TeoLogia

ISSN 2081-8971

$2017 \mathrm{nr} 30$, s. 52-69.

\section{Analityka internetowa ijej potencjał w trecim sektorze}

Internet analytics and its potential in the third sector

\begin{abstract}
STRESZCZENIE:
WIĘKSZOŚĆ ORGANIZACJI POZARZĄDOWYCH WYKORZYSTUJE INTERNET W SWOJEJ DZIAEALNOŚCI, ALE TYLKO CZĘŚĆ Z NICH BADA SKUTECZNOSĆ́ PROWADZONEJ KOMUNIKACJI. ARTYKUє JEST PRÓBĄ ODPOWIEDZI NA PYTANIE, CZY ORGANIZACJE TRZECIEGO SEKTORA MOGA POPRAWIĆ EFEKTYWNOŚĆ DZIĘKI BADANIU SWOICH DZIAŁAŃ INTERNETOWYCH ORAZ JAKIE RODZAJE BADAŃ SĄ PRZYDATNE I MOŻLIWE DO PRZEPROWADZENIA PRZEZ TĘ GRUPĘ ORGANIZACJI. AUTOR PRZEDSTAWIA BADANIA NAD DOJRZAŁOŚCIĄ ANALITYCZNĄ ORGANIZACJI

(DAVENPoRT / HARRIS). NA TEJ PODSTAWIE PRZEDSTAWIA WYNIKI WŁASNYCH BADAŃ PORÓWNAWCZYCH (2015/2017), GDZIE OCENIA, JAKA CZESŚĆ STRON ORGANIZACJI TRZECIEGO SEKTORA ZBIERA Dane o zachowaniu internautów. PRzestawiono

TEŻ PROPOZYCJĘ DZIESIĘCIU RODZAJÓW BADAŃ INTERNETU POŁĄCZONE Z OCENĄ PRZYDATNOŚCI TYCH BADAŃ DLA ORGANIZACJI POZARZADOWYCH.
\end{abstract}

\section{SŁOWA KLUCZOWE:}

ANALITYKA INTERNETOWA, ORGANIZACJE POZARZĄDOWE, NGO, NON-PROFIT, BADANIA, TRZECI SEKTOR, BIG DATA

\begin{abstract}
:
THE MAJORITY OF NON-GOVERNMENT ORGANIZATIONS USE INTERNET IN THEIR ACTIVITIES, BUT ONLY A FRACTION OF THEM INVESTIGATE THE EFFECTIVENESS OF COMMUNICATION. THIS ARTICLE ATTEMPTS TO ANSWER THE QUESTION OF WHETHER THIRD-SECTOR ORGANIZATIONS CAN IMPROVE THEIR EFFICIENCY BY RESEARCHING THEIR ONLINE ACTIVITIES AND WHAT KIND OF RESEARCH IS USEFUL AND FEASIBLE FOR THIS ORGANIZATION. THE AUTHOR PRESENTS A THEORY OF AN ORGANIZATION'S MATURITY (DAVENPORT / HARRIS). ON THIS BASIS, HE PRESENTS THE RESULTS OF ITS OWN COMPARATIVE STUDIES (2015 / 2017), WHICH ASSESSES WHAT PART OF THIRD-PARTY ORGANIZATIONS COLLECT DATA ON THE BEHAVIOR OF INTERNET USERS. THERE ARE ALSO PROPOSALS FOR TEN TYPES OF INTERNET RESEARCH COMBINED WITH THE ASSESSMENT OF THE USEFULNESS OF THESE RESEARCHES FOR NON-GOVERNMENTAL ORGANIZATIONS.
\end{abstract}

\section{KEYWORDS:}

INTERNET ANALYTICS, NGO, NON-PROFIT, RESEARCH, THIRD SEKTOR, BIG DATA 
W iele organizacji trzeciego sektora takich jak fundacje, stowarzyszenia czy organizacje religijne dzięki internetowi mogło zmienić sposób komunikacji i rozszerzyć zakres swojego działania. Omijając tradycyjne kanały stały się niezależnym dostawcą treści. Mogą samodzielnie, bez pomocy mediów, przedstawiać swoją działalność i przekonywać darczyńców do wsparcia ich działalności. Jeżeli jednak ich komunikacja w internecie ma być efektywna, to czy można opierać się jedynie na przeczuciu i intuicji? W artykule stawiam pytanie o rolę badań aktywności internetowej w działalności non-profit.

Praktyka i teoria badań internetu liczy już ponad 20 lat. Jednym z najstarszych narzędzi badania ruchu na stronach internetowych był Webalizer, zainicjowany w 1997 roku przez Bradforda L. Barretta. Narzędzie to pozwalało na podstawie analizy wpisów dziennika serwera www ( $\log$ analysis) obliczyć podstawowe wskaźniki ruchu na stronie takie, jak liczba odsłon, wizyt i najpopularniejsze adresy. Było bezpłatne i stosowane powszechnie przez webmasterów, choć w kolejnych latach wypierały je kolejne, coraz lepsze narzędzia. Kiedy jednak po dwudziestu latach spojrzymy na stopień wykorzystania badań internetu przez pryzmat trzech sektorów gospodarki: rządowego, prywatnego i non-profit, dostrzec można dużą dysproporcję. Sektor prywatny korzysta z badań internetu w stopniu zaawansowanym, a nowa dziedzina e-marketingu rozwija się w dużym tempie. Sektor rządowy zdaje się wprowadzać innowacje $w$ wolniejszym tempie, ale podejmuje wiele inicjatyw związanych z cyfryzacją państwa, choć nie zawsze wiąże się to z badaniami i zdolnością do korekty własnych działań na podstawie zebranych wyników. Podobna nierównowaga daje się zauważyć w publikacjach - większość sztandarowych tekstów na temat badań internetu odnosi się do marketingu firm komercyjnych, pewna część dotyczy cyfryzacji państwa. Prowadzenie badań internetu przez trzeci sektor, który wykazuje przecież aktywność w Sieci, jest tematem rzadko podejmowanym.

Artykuł jest próbą zwrócenia uwagi na znaczenie prowadzenia badań własnej aktywności internetowej podmiotów zaliczanych do trzeciego sektora i na potencjalny wpływ takich działań na poprawienie skuteczności ich działania. Już na wstępie warto zaznaczyć, że charakter działania organizacji pozarządowych różni się od charakteru działania firm komercyjnych - mają przecież inne cele, zobowiązania, budżety, różnią się dynamiką w czasie - dlatego nie skupiam się na możliwościach skopiowania wzorców badań e-marketingowych na obszar non-profit, a raczej na tym, jaką „swoją” analitykę mogłyby uprawiać organizacje trzeciego sektora. Staram się też wziąć pod uwagę realia trzeciego sektora, ponieważ są to często małe organizacje oparte na zasadach częściowego lub całkowitego wolontariatu. Dlatego wiele spektakularnych metod badań, opisanych w literaturze w kontekście firm takich, jak Google, Facebook, Amazon czy Netflix, pozostaje poza zasięgiem tych podmiotów.

Terminy „organizacja społeczna”, „trzeci sektor”, „organizacja non-profit” używane są zamiennie i ze względu na ogólny charakter artykułu nie rozbijam tych organizacji na żadne mniejsze kategorie, są one rzecz jasna wewnętrzne zróżnicowane. Według danych Stowarzyszenia Klon / Jawor, które kataloguje podmioty trzeciego sektora, w Polsce działa ich 138 tysięcy. Klon / Jawor zalicza do tej grupy jedenaście typów orga- 
nizacji: fundacje, stowarzyszenia, stowarzyszenia zwykłe, stowarzyszenia kultury fizycznej, stowarzyszenia ogrodowe, związki stowarzyszeń, związki sportowe, organizacje powstałe na podstawie umowy państwo-kościół, polskie przedstawicielstwa organizacji zagranicznych, nieformalne grupy i inicjatywy oraz spółdzielnie socjalne ${ }^{1}$.

Tekst składa się z trzech części. W pierwszej części zastanawiam się, jaką rolę dla różnego typu organizacji odgrywa analityka i prowadzenie badań. Wykorzystam w tym celu wnioski z teorii komunikacji i teorii business intelligence, uwzględniając historię badań nad tym zagadnieniem także z ery przedinternetowej. W drugiej części stawiam pytanie oto, czy organizacje pozarządowe potrzebują i korzystają z badań internetu. Przytaczam wyniki własnych pilotażowych badań empirycznych nad aktywnością internetową organizacji pożytku publicznego. W trzeciej części przedstawiam wybrane przykłady metod badania internetu, próbując odpowiedzieć na pytanie, czy są one przydatne z punktu widzenia organizacji non-profit.

\section{Rola analityki w organizacjach}

\section{Wartość sygnału zwrotnego w komunikacji}

Każda organizacja, która komunikuje się ze swoim otoczeniem, przyjmuje pewien wzorzec komunikacji, który wpływa na jej skuteczność. Przebieg komunikacji w dużej mierze zależy więc od „mentalności” organizacji i wydaje się, że nie ma przesady w znanym stwierdzeniu Marshalla McLuhana, że środek komunikacji jest także komunikatem. W zależności od tego, jakie są relacje między organizacją a jej odbiorcami, możemy mówić o wzorcu asymetrycznym lub symetrycznym. Kwintesencją wzorca asymetrycznego jest wykładana podczas kursu nauk o mediach teoria komunikacji Harolda Lasswella, który sprowadzał proces komunikacyjny do pytań: kto mówi, co, do kogo, jakim kanałem i z jakim skutkiem? Jak zauważa D. McQuail, stworzona w 1948 roku teoria opisuje komunikację w sposób bardzo linearny. ${ }^{2}$ I chociaż kolejni teoretycy komunikacji starali się rozbudować ten model, jego podstawowym założeniem jest asymetryczne rozróżnienie roli nadawcy i odbiorcy, rolą nadawcy jest mówienie, rolą odbiorcy - słuchanie. Nawet, jeśli wprowadzimy do tak sformułowanego modelu pojęcie sygnału zwrotnego, jednostronność komunikacji pozostaje. Sygnał zwrotny służy bowiem temu, by potwierdzić, że komunikat został poprawnie odczytany, nie zmienia jednak podziału ról nadawcy i odbiorcy. Komunikacja asymetryczna jest charakterystyczna dla tradycyjnych mass mediów, działalności propagandowej i starszych wzorców promocji marketingowej, w której przekonanie przedkłada się nad zrozumienie.

Na drugim krańcu znajduje się komunikacja symetryczna. Jej teoretycznych podstaw należy doszukiwać się raczej w znacznie nowszych socjologicznych teoriach społeczeństwa sieci (M. Castells) i teorii trzeciej fali (A. Toffler³). Sieć (zapisywana często wielką literą jako nazwa własna) rozumiana jest w tym paradygmacie jako ekosystem infor-

\footnotetext{
${ }^{1}$ Por. http://www.klon.org.pl/x/779969 [dostęp: 2017-11-04].

${ }^{2}$ Por. D. McQuail D, Teoria komunikowania masowego, Warszawa 2008, s. 85.

${ }^{3}$ A. Toffler, Trzecia fala, Warszawa 2006.
} 
macyjny. Pojęcia nadawcy i odbiorcy wydają się nieadekwatne, mówimy raczej o uczestnikach komunikacji, a wymiana informacji jest skomplikowanym dialogiem między uczestnikami, którego elementy, niczym w mozaice, składają się na większy obraz. Społeczeństwo ewoluuje od miejskiego środowiska ery przemysłowej do społeczeństwa informacyjnego, w których bliskość relacji definiowana jest połączeniami sieciowymi.

Myślenie w kategoriach komunikacji symetrycznej staje się coraz bardziej popularne pod wpływem rozwoju internetu i portali społecznościowych. Autorzy prac opublikowanych już w erze internetu zwracają na przykład uwagę na zupełnie nowe modele tworzenia treści i współpracy (D. Tapscott ${ }^{4}$ ) oraz niekiedy kontrowersyjny model tworzenia kultury w epoce Web 2.0 (A. Keen ${ }^{5}$ ). Są to oczywiste przykłady komunikacji symetrycznej.

Chociaż model symetryczny wydaje się bardziej dopasowany do środowiska internetowego, wobu modelach komunikacji pojawia się podstawowy problem sygnału zwrotnego, który w procesie komunikowania w organizacji pełni podobną rolę, co zmysły dla organizmu człowieka. W tak dynamicznym środowisku, jakim jest internet, aktywność bez uwzględnienia sygnału zwrotnego można uznać za działanie na oślep. W wielu wcześniejszych środowiskach można było działać bez sygnału zwrotnego, ponieważ były one dużo bardziej przewidywalne, miały mniejszy zakres i rozwijały się wolniej, w internecie jednak szukanie feedbacku jest niczym dogmat, a rezygnacja z informacji zwrotnej z dużym prawdopodobieństwem doprowadzi do efektu nieadekwatnego do poniesionych nakładów. Głównym celem analityki internetowej jest więc dostarczenie lub wydobycie informacji o charakterze sygnału zwrotnego, pozwalającego na ocenę efektu. Różnica między dostarczeniem a wydobyciem informacji polega na tym, że w wielu przypadkach „surowe” dane z badań nie mają wartości informacyjnej i wymagają przetworzenia polegającego na przykład na zagregowaniu, odfiltrowaniu czy pogrupowaniu danych oraz dalszej obróbce statystycznej. Z tego powodu konsekwentnie używam w tym tekście terminu ,analityka”, a nie na przykład popularnego w ostatnich latach „Big Data”. Mówiąc o analityce podkreślamy bowiem, że dane nie stają się od razu wiedzą - by stały się wiedzą, potrzebne są umiejętności analityczne, nawyki działania oraz odpowiednie narzędzia.

Co jednak wydarzy się, gdy organizacja nie będzie zainteresowana sygnałem zwrotnym lub nie będzie w stanie wydobyć wartościowej wiedzy? W asymetrycznym modelu komunikacji organizacja nie wie, czy udało się przekazać komunikat w sposób zgodny z oczekiwaniami i czy dotarł on do adresatów. W symetrycznym modelu mogłoby się wydawać, że dzięki zaangażowaniu internautów komunikacja może odbywać się bez żadnych badań czy nadzoru, nie ma jednak pewności, w jakim kierunku się ona toczy, jak jest skuteczna i czy nie uzyskano efektu odwrotnego od zamierzonego. Dlatego nawet firmy takie, jak Google i Facebook, które starają się zachować neutralność względem dostarczanej przez użytkowników treści, stosują automatyczne sprawdzenie, czy na

\footnotetext{
${ }^{4}$ D. Tapscott, A. D. Williams, Wikinomia. O globalnej współpracy, która zmienia wszystko, Warszawa 2008.

${ }^{5}$ A. Keen, Kult amatora. Jak internet niszczy kulturę, Warszawa 2007.

${ }^{6}$ V. Mayer-Schönberger, K. Cukier, Big Data, Warszawa 2014.
} 
przykład strona nie propaguje nazizmu, zdjęcie nie zawiera pornografii, a wpis na forum nie jest wulgarny. Niezależnie od modelu komunikacji przykłady można mnożyć domalowywanie wąsów i wyzwisk na plakatach, publikowanie przerobionych reklam na YouTube, retweetowanie oryginalnych wypowiedzi wraz ze złośliwym komentarzem, a w skrajnych przypadkach duża liczba nienawistnych wypowiedzi na forum lub profilu, która zmusiła właściciela do całkowitego zamknięcia strony.

Na koniec tego wstępu z teorii komunikacji warto jeszcze zaznaczyć, że w opinii wielu autorów, badanie skuteczności komunikacji przez organizację nie oznacza automatycznie, że organizacja potrafi z tego badania skorzystać, liczy się zatem nie tylko warsztat badawczy, ale też umiejętność przyswojenia wyników w całej organizacji. Nieważne, czy organizacja bada swoją komunikację, lecz czy umie i chce się czegoś nauczyć z zebranych danych. Tylko wtedy mogą być one katalizatorem rozwoju.

\subsection{Wpływ prowadzenia badań na organizacje}

Analityka internetowa jest młodszą siostrą znacznie starszej dziedziny - analityki biznesowej, która od wielu lat służy jako narzędzie wspomagające rozwój firm. Klasyczna analityka biznesowa wywodziła się z dziedziny finansów. Jest to zrozumiałe, prawo zobowiązuje większość firm do gromadzenia szczegółowej dokumentacji finansowej, a program każdych studiów ekonomicznych zawiera obszerny kurs metod ilościowych. Jeszcze przed nastaniem epoki internetu firmy dysponowały zatem obszernymi zbiorami danych finansowych, które można analizować. Stąd, istnieje dość rozpowszechniony pogląd polegający na utożsamianiu analityki biznesowej z księgowością. Jest on z dzisiejszego punktu widzenia błędny i może prowadzić do mylnych wniosków.

Okazuje się, że analityka biznesowa stawia sobie inne cele niż księgowość. Jej zadaniem nie jest wykonanie standardowego bilansu, ale zrozumienie całości firmy poprzez liczby - dochodowości poszczególnych produktów, zmian dokonujących się w czasie, obserwowanie trendów, odkrywanie nowych szans rozwojowych i szybkie wyłapywanie zagrożeń, a może przede wszystkim - obiektywizowanie opisu firmy poprzez wskaźniki liczbowe. Tak rozumiana analityka wykracza szeroko poza obszar ksiąg rachunkowych i staje się strategicznym narzędziem służącym firmie do rozwoju. Jeżeli potraktować wynagrodzenie jako miernik ważności danego stanowiska dla firmy, znaczący wydaje się fakt, że według badań firmy Sedlak \& Sedlak mediana wynagrodzenia analityka finansowego w Polsce wynosiła $5645 \mathrm{zł}$ brutto, podczas gdy na przykład specjalisty ds. PR - $4480 \mathrm{zl}$, a wzmiankowanego księgowego - 3597. ${ }^{7}$ Pokazuje to nie tylko pozycję analityków w firmie, ale też potwierdza tezę o znaczącej różnicy między rolą analityka a księgowego.

Rosnąca odrębność roli analityki doprowadziła do wyodrębnienia nowej dziedziny wiedzy - business intelligence (BI), w której nacisk położono na zdobywanie i analizowanie wszelkiego rodzaju danych, mogących przysłużyć się rozwojowi firmy. W klasycznym i chętnie cytowanym do dziś podręczniku BI autorstwa Davenporta i Harrisa, pojęcie analityki jest już definiowane w całkiem nowy, bardzo współczesny sposób:

${ }^{7}$ Por. http://wynagrodzenia.pl/moja_placa.php?s=96 [dostęp 2017-11-04]. 
„Pod pojęciem analityki rozumiemy szerokie wykorzystanie danych, analizy statystycznej i ilościowej, modeli wyjaśniających i prognostycznych oraz zarządzania w oparciu o fakty - przy podejmowaniu decyzji i działań. Mogą to być decyzje podejmowane przez człowieka lub całkowicie automatycznie. Analityka stanowi podzbiór tego, co przyjęło się określać terminem business intelligence: zestawu technologii i procesów, w których wykorzystuje się dane, by zrozumieć i analizować wyniki biznesowe". ${ }^{8}$

Dochodzimy w ten sposób do wniosku, że poprawnie wykorzystywana analityka ma charakter strategiczny dla organizacji i jest pomocna przy podejmowaniu najważniejszych decyzji krótko- i długoterminowych. Może też zdecydować o przewadze konkurencyjnej dzięki szybszej reakcji lub zauważeniu w danych czegoś trudnego do uchwycenia bez narzędzi analitycznych. Davenport i Harris idą jednak dalej i mówią o dojrzałości analitycznej organizacji, wyróżniając pięć poziomów konkurencji analitycznej: od etapu trudności związanych z brakiem potrzebnych danych, przez wykorzystanie analityki do poprawiania działania, rozszerzenie analityki na całą firmę i umiejętność prognozowania, po etap firmy, w której analityka jest motorem osiągania wyników, po etap mistrzostwa w analityce i utrzymywaniu dzięki nim trwałej przewagi konkurencyjnej ${ }^{9}$.

Uogólniając i upraszczając model Devenporta/Harris, można go sprowadzić do kilku uniwersalnych etapów rozwoju analityki w każdej niemal organizacji, nie tylko w sektorze komercyjnym. Im dalszy etap, tym większa dojrzałość organizacji w obszarze analityki.

\begin{tabular}{|l|l|l|} 
Etap & Nazwa & Opis \\
\hline 1 & Dane & Zbieranie danych \\
\hline 2 & Wiedza & Rozumienie danych \\
\hline 3 & Sygnał zwrotny & Zmiana sposobu działania dzięki danym \\
\hline 4 & Prognozowanie & Przewidywanie faktów i planowanie rozwoju dzięki danym \\
\hline
\end{tabular}

Tabela 1. Etapy rozwoju analityki w organizacji. Źródło: opracowanie własne na podstawie T. Davenport, J. Harris, Inteligencja analityczna w biznesie. Nowa nauka zwyciężania, Warszawa 2010.

Z powyższego zestawienia wynika, że wraz ze wzrostem kompetencji analitycznych można oczekiwać poprawy sprawności całej organizacji. Davenport i Harris podają na podstawie badania własnego, przeprowadzonego wśród 450 menedżerów dużych i średnich przedsiębiorstw, że istnieje uderzająca korelacja między wykorzystywaniem analityki a wynikami biznesowymi. Badając, czy firmy mają istotne kompetencje analityczne i wsparcie decyzyjne, zaobserwowali to w $23 \%$ podmiotów ze złymi wynikami i aż w $65 \%$ firm z dobrymi wynikami. Z badania wynika także, że chęć podniesienia wydajności i obniżenia kosztów nie jest jedynym motywatorem dla wprowadzania systemów

\footnotetext{
${ }^{8}$ T. Davenport, J. Harris, Inteligencja analityczna w biznesie. Nowa nauka zwyciężania, Warszawa 2010, s. 24.

${ }^{9}$ Tamże, s. 60-61.
} 
inteligencji biznesowej. Okazuje się bowiem, że ponad połowa respondentów podała jako główny powód wprowadzania takich rozwiązań lepsze podejmowanie decyzji dzięki systemom BI. Firmy z dobrymi wynikami o połowę częściej w porównaniu do całej próby wykorzystywali analitykę do celów strategicznych ${ }^{10}$.

Patrząc na rolę badań w obszarze internetu można powiedzieć, że jej znaczenie rośnie, a proces uświadamiania sobie wartości tych badań i uczenia się korzystania z nich przebiega stopniowo i z całą pewnością się nie zakończył. Da się go zaobserwować na przykładzie stopniowej ewolucji narzędzi badawczych sieci web (np. 1997 - Webalizer, 1999 - Gemius Trafiic, 2005 - Google Analytics, 2015 - Gemius Overnight) oraz social media (na przykład 2004 - licznik polubień Facebooka, 2011 - Sotrender) ${ }^{11}$. Nie jest moim celem streszczanie tutaj historii badań internetu, chciałbym jednak zwrócić uwagę na trzy momenty, które wpłynęły na sposób rozumienia roli sieciowych badań.

Pierwsze wydarzenie łączy się z Jacobem Nielsenem, wybitny ekspertem w dziedzinie użyteczności produktów komputerowych i badania interfejsów użytkownika, który w 1999 roku opublikował głośną pracę na temat użyteczności stron internetowych ${ }^{12}$. Nielsen zwracał w niej uwagę na konieczność badania ergonomii stron www i stosowania się do prostych heurystyk projektowych. W latach rozpowszechniania się książki był to postulat nowatorski, nikt wówczas nie myślał o konieczności zbadania, czy produkt internetowy nadaje się do używania przez przeciętnego internautę, budowanie strony uważano za czynność ściśle techniczną, bez uwzględniania kontekstu odbiorcy i ergonomii produktu z jego punktu widzenia. Dziś możemy przyznać, że sytuacja jest diametralnie inna i każdy profesjonalny projekt internetowy przechodzi przez jakąś formę badania jakości interfejsu.

Drugim wydarzeniem jest popularyzacja analityki internetowej przez Avinasha Kaushika, w serii książek poświęca uwagę temu, jak wkomponować badania internetu w całą strategię działania organizacji ${ }^{13}$. Prace Kaushika odróżniają się od innych prac poświęconych badaniom internetu tym, że nie koncentruje się on na narzędziach, ale na strategicznej roli analityki i umiejętności prawidłowego zdefiniowania celów oraz interpretacji danych, zwraca też uwagę na konieczność indywidualizacji prowadzonych badań i świadomego zdefiniowania własnych mierników sukcesu. Wydaje się, że Kaushik dobrze łączy w swoich pracach technologię i narzędzia ze strategią i celami biznesowymi.

Trzecim momentem jest stopniowe odkrywanie roli danych w działalności firm, zjawisku, któremu w języku marketingowym często nadaje się etykietę Big Data. Termin ten odnosi się zwykle do rosnącej liczby danych w internecie, zdolności firm do ich analizy oraz zastosowania technik modelowania opartych na pełnych danych zamiast na małych próbkach statystycznych. Podejście to opisali obszernie w 2013 r. V. May-

10 Tamże, s. 72-74.

11 Zob. także A. Miotk, Skuteczne social media, Gliwice 2017.

12 J. Nielsen, Projektowanie funkcjonalnych serwisów internetowych, Gliwice 2003.

13 A. Kaushik, Godzina dziennie z Web Analytics. Stwórz dobrą strategię e-marketingową, Gliwice 2009.

Tenże, Web Analytics 2.0. Świadome rozwijanie witryn internetowych, Gliwice 2010. 
er-Schönberger i K. Cukier ${ }^{14}$. Termin Big Data nie wydaje się do końca precyzyjny, w zjawisku tym nie chodzi bowiem o wielkość danych (jak ocenić czy dane są już „duże”?), lecz raczej o ich kompletność a przede wszystkim o zdolność organizacji do ich analizowania (co przyznają sami autorzy). Zjawisku temu towarzyszy pojawienia się nowego zawodu - badacza danych - obejmującego kompetencje w zakresie technologii, statystyki i biznesu ${ }^{15}$ oraz studiów z tego obszaru ${ }^{16}$.

\section{Organizacje społeczne wobec analityki}

\subsection{Zapotrzebowanie na badania}

Trzeci sektor działa inaczej niż firmy. Organizacje społeczne nie skupiają się na osiągnięcia zysku, są inaczej zorganizowane, rzadko kiedy mają do dyspozycji pełnoetatowych pracowników i należałoby spytać, jakie korzyści może przynieść analityka internetowa dla podmiotów trzeciego sektora. Wcześniej wymieniłem już ogólne zalety korzystania z analityki dla różnego typu organizacji. Interesuje nas jednak specyfika tej grupy organizacji. W trakcie przygotowywania tekstu konsultowałem się indywidualnie oraz podczas konferencji z osobami związanymi z sektorem NGO. W trakcie tych rozmów dało się zauważyć pewien dystans do idei prowadzenia badań internetowych przez te organizacje. Oto przykłady sceptycznych głosów, z którymi się spotkałem:

1. „Dziedzina typowo biznesowa” - analityka kojarzy się przede wszystkim z biznesem i z przetwarzaniem danych o charakterze finansowym. Dla organizacji realizujących cele społeczne nie musi to mieć takiego znaczenia.

2. „Drogie narzędzia, trudne w obsłudze” - istnieje przekonanie, że do prowadzenia badań potrzebne są bardzo wysokie kompetencje w zakresie matematyki i statystyki oraz drogie, zaawansowane oprogramowanie. Analityka pozostaje zatem poza zasięgiem organizacji non-profit.

3. „Narzędzia analityczne potrzebne są tylko zarządowi do podsumowania rocznego" - w świetle takiego twierdzenia nawet jeśli zarząd fundacji potrzebuje danych aby podsumować w raporcie kolejny rok działalności, nie ma to większego przełożenia na działanie całej organizacji.

4. „Służy do autoreklamy” - argument wysuwany czasem przez organizacje o charakterze religijnym, które doszukują się w korzystaniu z narzędzi pomiarowych ukrytej próby potwierdzenia własnej wartości i potęgi swojej organizacji, co z kolei budzi wątpliwości etyczne. Zgodnie z tym poglądem, członkowie organizacji powinni dążyć do realizacji celu, który jest ambitny i trudny do osiągnięcia i nie oczekiwać za to emocjonalnej gratyfikacji, jaką są „osiągnięcia”. Zwolennicy tego poglądu uważają, że należy dążyć do ideałów niezależnie od stopnia akceptacji społecznej.

14 V. Mayer-Schönberger, K. Cukier, Big Data, Warszawa 2014.

15

P. Biecek, Jak kształcić Data Scientists / Badaczy Danych?,

http://smarterpoland.pl/index.php/2015/11/jak-ksztalcic-data-scientists-badaczy-danych/ [dostęp: 2017-11-04].

16

Zob. http://datascience.edu.pl/ [dostęp: 2017-11-04]. 


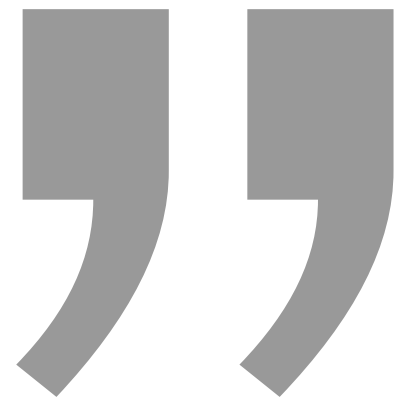

Dla organizacji pozarządowych internet jest

o wiele ważniejszym kanałem komunikacji

niż dla firm. Obecnie większość firm stara się

mieć swoją stronę internetową czy profil

w portalach społecznościowych ze względów

wizerunkowych, ale działalność znaczącej liczby

firm nie wiąze się bezpośrednio z obecnością

w Sieci. W przypadku organizacji społecznych

sytuacja wyglą̨a diametralnie inaczej

- istotą ich działania jest stałe komunikowanie

się ze swoim otoczeniem i troska o wizerunek.

Z takimi głosami trudno się do końca zgodzić, ale trzeba też przyznać, że świadczą o rozumieniu specyfiki trzeciego sektora, który nie powinien bezkrytycznie kopiować wzorców działań zaczerpniętych ze świata biznesu. Jednak, jak wykazałem wcześniej, (ad 1.) analityka w dzisiejszym rozumieniu nie koncentruje się już jedynie na finansach, a umiejętność rozwijania organizacji wykorzystując analizę danych wydaje się interesującą propozycją także w działalności niekomercyjnej. (ad 2.) Znaczna część narzędzi do analizy danych jest obecnie dostępna całkowicie bezpłatnie i do podstawowego korzystania z nich nie jest wymagana bardzo specjalistyczna wiedza. (ad 3.) Narzędzia analityczne mogą być rzecz jasna wykorzystane przez zarząd organizacji, ale nawet w świecie biznesu ograniczenie ich wyłącznie na potrzeby managementu albo wykorzystanie jedynie sporadycznie, na potrzeby rocznych raportów, uważane jest za nieprawidłowe wdrożenie. (ad 4.) W kwestii etycznej można zgodzić się z troską o czystość intencji, jednak celem prowadzenia badań jest uzyskanie możliwie najbardziej obiektywnego obrazu sytuacji. Praktyka prowadzenia badań pokazuje jednak, że prawie zawsze wyniki takich badań wskazują na obszary wymagające poprawy. Wydaje się więc, że o wiele większe ryzyko jest związane z podejmowaniem działań w internecie wyłącznie w oparciu o subiektywne przekonania.

Równocześnie poważne argumenty przemawiają na rzecz wykorzystania analityki internetowej w trzecim sektorze.

1. Dla organizacji pozarządowych internet jest o wiele ważniejszym kanałem komunikacji niż dla firm. Obecnie większość firm stara się mieć swoją stronę internetową czy profil w portalach społecznościowych ze względów wizerunkowych, ale działalność znaczącej liczby firm nie wiąże się bezpośrednio z obecnością w Sieci. W przypadku organizacji społecznych sytuacja wygląda diametralnie inaczej istotą ich działania jest stałe komunikowanie się ze swoim otoczeniem i troska o wizerunek. W przeciwieństwie do firm, które często mogą sobie pozwolić na 
różnorodne formy płatnej promocji, dla trzeciego sektora internet udostępnia narzędzia pozwalające na bezpośrednią komunikację ze swoimi odbiorcami, przy zachowaniu minimalnego kosztu. Jeśli więc istnieją sposoby, by za pomocą badań poprawić skuteczność tej komunikacji, wydaje się, że trzeci sektor powinien tym być zainteresowany znacznie bardziej niż komercyjne firmy.

2. Organizacje społeczne ze swojej natury muszą być sprytne w tym znaczeniu, że choć dysponują ograniczonymi środkami, nieraz prowadzą duże projekty, wymagające bardzo dobrej efektywności działania. Ponieważ jednym z dobrodziejstw prowadzenia szeroko rozumianej analityki jest otrzymywanie informacji zwrotnej na temat realnego efektu swoich działań, można dzięki temu działać znacznie sprawniej i metodą małych kroków stale poprawiać wykorzystanie zasobów lub przeciwdziałać ich marnotrawstwu.

3. Ważną cechą organizacji społecznej jest umiejętność dostosowywania się do otoczenia, które się zmienia; pojawiają się nowe problemy do rozwiązania, wymieniają się wolontariusze, zmieniają się zasady przyznawania grantów etc. Jednym słowem, im bardziej organizacja jest wrażliwa na swoje otoczenie, tym skuteczniej może działać. Prowadzenie choćby prostych badań jest jedną z form trzymania ręki na pulsie.

\subsection{Ocena wykorzystania badań internetowych}

Po tym teoretycznym uzasadnieniu chciałbym opisać pilotażową próbę oszacowania stopnia wykorzystania internetu i analityki sieciowej w sektorze non-profit. Dogłębne zbadanie tego tematu jest dużym wyzwaniem, biorąc pod uwagę, że tylko w Polsce mówimy o 138 tysiącach organizacji, jest to więc temat na znacznie większe badanie i publikację bardziej obszerną niż artykuł. Dlatego do pilotażu został wybrany prosty - ale latwy do powtarzania - schemat badania, któremu poddano dwie grupy organizacji, łatwe do precyzyjnej identyfikacji. Pierwsza grupa to organizacje pożytku publicznego, które w polskim systemie podatkowym są beneficjentami odpisu $1 \%$ podatku. Organizacje te podlegają rejestracji i muszą spełnić pewne dodatkowe wymogi formalne aby otrzymywać środki z podatków, można więc oczekiwać, że będą dość starannie organizowały swoją komunikację internetową. Drugą grupą poddaną testowi były wszystkie diecezje rzymskokatolickie obrządku łacińskiego w Polsce. Obie grupy spełniają podane na początku kryteria organizacji trzeciego sektora, a ich pełna lista jest możliwa do weryfikacji na podstawie publicznie dostępnych wykazów.

Badanie polegało na zestawieniu i ręcznym zweryfikowaniu listy stron internetowych dla prób zaczerpniętych z dwóch badanych grup. Następnie strony te zostały przeanalizowane za pomocą przygotowanego na potrzeby badania programu, który sprawdzał, czy strony te mają zainstalowane popularne skrypty do mierzenia ruchu (Google Analytics, Piwik, Gemius). Na tej podstawie możliwe było stwierdzenie, jak duża część instytucji z danej grupy posiada swoje strony internetowe oraz jaka ich część zawiera zainstalowane narzędzia analityczne. Ten rodzaj testu jest łatwy do powtórzenia, nie wymaga udziału właścicieli stron i dostarcza dane faktyczne, a nie deklaratywne. Ograniczeniem testu jest to, że nie można jednoznacznie stwierdzić na 


\section{PUBLIC RELATIONS W INSTYTUCJACH NON-PROFIT}

podstawie zainstalowania skryptu mierzącego, że dane te są w jakiś sposób wykorzystywane przez wydawcę strony, można jednak dokonać falsyfikacji - brak typowych skryptów mierzących na stronie wyklucza możliwość analizy ruchu.

Badanie zostało przeprowadzone w listopadzie 2015 roku, a następnie powtórzone dwa lata później. W przypadku organizacji pożytku publicznego z oficjalnej bazy 7971 stron komputerowo wylosowano próbkę 100 elementów (ze względu brak w bazie adresów stron, wymagały one ręcznego znalezienia), która została powtórzona w drugim teście oraz pełną próbę wszystkich diecezji rzymskokatolickich, podział na diecezje nie uległ zmianie w badanym okresie.

W przebadanej próbie osiem na dziesięć stron organizacji pożytku publicznego miało swoje strony internetowe z niewielką tendencją rosnącą w perspektywie badanych dwóch lat, tendencja ta pozostawała jednak na granicy błędu statystycznego. Mniej niż jedna na trzy istniejące strony zawierała kody zliczające, co wydaje się wartością niską, bez wyraźnego trendu wzrostowego. W odniesieniu do całej próbki (posiadających i nieposiadających strony), tylko co czwarta organizacja zbierała dane o ruchu, pozwalające na analizę. Warto odnotować w 2017 roku nowe niewielkie zjawisko, polegające na zakładananiu fanpage'y na Facebooku w przypadku braku klasycznej strony www ( $3 \%$ badanych organizacji), co ciekawe w 3\% przypadków doszło też do zamknięcia stron w 2017 roku względem 2015.

\begin{tabular}{|c|c|c|c|c|}
\hline & \multicolumn{2}{|c|}{ Organizacje pożytku publicznego } & \multicolumn{2}{|c|}{ Diecezje rzymskokatolickie } \\
\hline & 2015 & 2017 & 2015 & 2017 \\
\hline 1. Liczba podmiotów & 7971 & 8517 & 42 & 42 \\
\hline 2. Badana próba & $\mathrm{n}=100$ & $\mathrm{n}=100$ & $\mathrm{n}=42$ & $\mathrm{n}=42$ \\
\hline $\begin{array}{l}\text { 3. Odsetek podmiotów po- } \\
\text { siadających strony www }\end{array}$ & $\begin{array}{l}77,0 \% \\
\text { błąd stand. } 4,2 \%\end{array}$ & $\begin{array}{l}81,0 \% * \\
\text { błąd stand. 3,9\% } \\
\text { *wliczając Facebook } \\
84 \%\end{array}$ & $\begin{array}{l}\text { 100,0\% } \\
\text { błąd stand.- }\end{array}$ & $\begin{array}{l}\text { 100,0\% } \\
\text { błąd stand. - }\end{array}$ \\
\hline $\begin{array}{l}\text { 4. Odsetek stron zawiera- } \\
\text { jących kody zliczające }\end{array}$ & $\begin{array}{l}29,0 \% \\
\text { błąd stand. } 5,1 \% \\
(22,0 \% \text { całości })\end{array}$ & $\begin{array}{l}29,6 \% \\
\text { błąd stand. } 4,6 \% \\
(24,0 \% \text { całości })\end{array}$ & $\begin{array}{l}52,0 \% \\
\text { błąd stand. - } \\
(52,0 \% \text { całości })\end{array}$ & $\begin{array}{l}61,9 \% \\
\text { błąd stand. - } \\
(61,9 \% \text { całości) }\end{array}$ \\
\hline $\begin{array}{l}\text { 5. Rozkład popularności } \\
\text { systemów mierzenia ru- } \\
\text { chu (suma }=100 \% \text { ): }\end{array}$ & & & & \\
\hline a) Google Analytics & $100,0 \%$ & $95,9 \%$ & $95,5 \%$ & $96,2 \%$ \\
\hline b) Piwik & $0,0 \%$ & $0,0 \%$ & $4,5 \%$ & $3,8 \%$ \\
\hline c) Gemius & $0,0 \%$ & $4,1 \%$ & $0,0 \%$ & $0,0 \%$ \\
\hline
\end{tabular}

Tabela 2. Wykorzystanie analityki w sektorze pozarządowym. Źródło: badanie własne, listopad 2015 - listopad 2017. 
W przypadku diecezji rzymskokatolickich, wszystkie miały własne strony internetowe. Biorąc jednak pod uwagę to, że diecezje (kurie) są często większymi organizacjami niż fundacje czy stowarzyszenia, zrozumiałe jest, że każda z nich dba o obecność w internecie (dla porównania, 54,8\% polskich parafii ma strony www ${ }^{17}$ ). Wzrósł jednak o 10 punktów procentowych odsetek stron zawierających kody zliczające z 52 do 62 procent, co wydaje się wyraźnym trendem w dobrym kierunku.

Poza jednostkowymi przypadkami podstawowym narzędziem pomiaru ruchu okazał się Google Analytics, co jest zjawiskiem typowym dla niekomercyjnych stron. Badanie pokazało różnicę w stopniu oskryptowania stron organizacji pożytku publicznego i diecezji, z zebranych danych nie można jednak jednoznacznie stwierdzić, czy wynika to z typu organizacji, czy może raczej z jej wielkości i dojrzałości instytucjonalnej. W obu przypadkach wydaje się, że odsetek stron zawierających kody zliczające jest stosunkowo niski, należałoby się spodziewać się raczej wskaźnika na poziomie przynajmniej 70-80\%. Obecne wskaźniki zdają się pokazywać, że badanie efektu komunikacji w internecie nie jest traktowane w sposób priorytetowy.

\section{Narzędzia analityczne dla organizacji społecznych}

Nie istnieje oficjalny wykaz metod badania internetu i obecnie trudno byłoby nawet podać ich orientacyjną liczbę. Wynika to nie tylko z dynamicznego rozwoju e-marketingu, ale przede wszystkim z rosnącej specjalizacji badań i coraz większego zróżnicowania potrzeb. Organizacje korzystające z Sieci mogą na przykład w rozmaitych proporcjach korzystać ze stron www, stron mobilnych, platform sprzedażowych, email marketingu i mediów społecznościowych (także w różnych kombinacjach). W efekcie daje to zupełnie różne zestawy badań, skoncentrowane na różnych wskaźnikach. Zjawisko tak dużej specjalizacji nie musi być oceniane zawsze pozytywnie, silne zróżnicowanie narzędzi powoduje bowiem trudności w ustaleniu standardów i zanikanie prostych, jednolitych miar sukcesu w Sieci.

Mimo to chciałbym podjąć próbę wybrania i oceny kilku elementarnych technik badawczych, które mogą być użyteczne dla typowej organizacji non-profit. Wybierając listę dziesięciu technik do dalszej oceny, kierowałem się kilkoma prostymi założeniami: (1) Organizacja komunikuje się w internecie przede wszystkim za pomocą strony www, media społecznościowe mają charakter pomocniczy, a email marketing nie odgrywa kluczowej roli. (2) Narzędzia powinny być proste i tanie, a ich liczba nie może być zbyt duża. (3) Uwzględniono „klasyczne” techniki badania, które są w użyciu co najmniej od kilku lat i znane są już ich mocne i słabe strony. (4) Przynajmniej niektóre techniki powinny dawać możliwość prowadzenia longitudalnych badań i porównywania wskaźników w perspektywie kilku lat. Poniższe zestawienie nie jest więc wyczerpującym zestawem technik badania Sieci, jest jednak propozycją pewnego planu badawczego dla przeciętnej organizacji trzeciego sektora. Niekiedy plan ten będzie wymagał przebudowy.

17 http://www.katolik.pl/parafie/ [dostęp: 2017-11-04]. Dane podawane przez portal katolik.pl dotyczą parafii polskojęzycznych także poza granicami kraju. 


\begin{tabular}{|c|c|c|c|c|}
\hline & & Przydatne? & Cele do zrealizowania & $\begin{array}{l}\text { Przykładowe narzędzia } \\
\left({ }^{*}=\text { bezpłatne }\right)\end{array}$ \\
\hline 1 & $\begin{array}{l}\text { Analiza ruchu i za- } \\
\text { sięgu (traffic) }\end{array}$ & Tak & $\begin{array}{l}\text { Poznanie zasięgu strony (użytkownicy, } \\
\text { odsłony). Obserwowanie trendów w cza- } \\
\text { sie. Weryfikacja popularności artykułów. } \\
\text { Poznanie źródeł ruchu i powracalności } \\
\text { użytkowników }\end{array}$ & $\begin{array}{l}\text { Google Analytics*, Piwik*, } \\
\text { Gemius Prism }\end{array}$ \\
\hline 2 & Badanie realtime & Niekiedy & Szybka informacja zwrotna nt. ruchu & $\begin{array}{l}\text { Google Analytics*, Gemius } \\
\text { Prism, Gemius Heatmap }\end{array}$ \\
\hline 3 & Prototypowanie & Tak & Szybka ewaluacja pomysłów & Kartka i ołówek, Balsamiq \\
\hline 4 & Testy A/B & Niekiedy & Wybór lepszego wariantu & - \\
\hline 5 & Badanie audience & Niekiedy & $\begin{array}{l}\text { Porównanie z innymi i obiektywizacja } \\
\text { wyników }\end{array}$ & $\begin{array}{l}\text { Gemius / PBI, Alexa, Sotren- } \\
\text { der }\end{array}$ \\
\hline 6 & Ankieta & Niekiedy & Poznanie opinii odbiorców & $\begin{array}{l}\text { LimeSurvey*, Google } \\
\text { Forms* }\end{array}$ \\
\hline 7 & Badanie SEO & Tak & Poprawa widoczności w wyszukiwarkach & Google Search Console* \\
\hline 8 & Okulografia & Nie & $\begin{array}{l}\text { Poznanie ścieżek, którymi podąża wzrok } \\
\text { na stronie }\end{array}$ & $\begin{array}{l}\text { Specjalistyczny sprzęt } \\
\text { i oprogramowanie do oku- } \\
\text { lografii }\end{array}$ \\
\hline 9 & $\begin{array}{l}\text { Analiza heury- } \\
\text { styczna }\end{array}$ & Tak & $\begin{array}{l}\text { Wprowadzenie dobrych praktyk budowy } \\
\text { strony. Naprawa typowych błędów na } \\
\text { stronie }\end{array}$ & - \\
\hline 10 & $\begin{array}{l}\text { Wywiad indywidu- } \\
\text { alny }\end{array}$ & Tak & $\begin{array}{l}\text { Zrozumienie odbioru strony przez inter- } \\
\text { nautów. Weryfikacja podstawowych funk- } \\
\text { cjonalności strony }\end{array}$ & Camtasia, Camstudio* \\
\hline
\end{tabular}

Tabela 3. Ocena przydatności wybranych metod badań internetu dla trzeciego sektora. Źródło: opracowanie własne.

Wszystkie wymienione metody i techniki badań należą do klasycznego zestawu narzędzi używanego przez firmy prowadzące strony www. Po zestawieniu tych technik z potrzebami organizacji non-profit okazuje się jednak, że duża część tych technik może mieć zastosowanie także w sektorze NGO. Jedynym badaniem, które uznałem za mało przydatne, jest okulografia (eye tracking), czyli badanie polegające na śledzeniu ruchu gałki ocznej śledzącej obraz na monitorze. Badanie to jest niekiedy stosowane w wysokobudżetowych projektach badawczych, wymaga jednak dostępu do bardzo drogiego, specjalistycznego sprzętu, jego przeprowadzenie jest dość trudne, wyniki niejednoznaczne i dla typowej organizacji społecznej wydaje się zbędne.

Z pozostałych typów badań obowiązkowym punktem dla każdego podmiotu prowadzącego stronę www wydaje się mierzenie ruchu i zasięgu, czyli badanie typu traffic (określane też jako site-centric). Badanie odbywa się automatycznie po umieszczeniu na stronie kodów śledzących. Dzięki dostępności bezpłatnych narzędzi analitycznych ta- 
kich jak na przykład Google Analytics, uzyskujemy bogaty zbiór informacji, pozwalający śledzić liczbę unikalnych użytkowników odwiedzających stronę, liczbę odsłon, średni czas trwania wizyty, źródła ruchu i zmiany tych wskaźników w czasie. Oprócz ogólnej charakterystyki strony narzędzia typu traffic pozwalają dokładniej śledzić np. popularność poszczególnych części strony lub konkretnych tekstów. Dla redaktora strony www jest to bezcenna informacja, umożliwia bowiem obserwowanie preferencji odbiorców, a także wyłapywanie miejsc, których popularność plasuje się poniżej oczekiwań. Dzięki systematycznej, regularnej pracy z narzędziami analitycznymi - tak jak sugeruje to autorytet w dziedzinie analityki webowej Avinash Kaushik - możliwe jest usprawnianie komunikacji i stopniowe jej poprawianie. ${ }^{18}$

W niektórych przypadkach przydatna może się okazać analityka czasu rzeczywistego. Jest to odmiana badań traffic, w których informacje na temat ruchu dostarczane są z minimalnym opóźnieniem rzędu kilku minut. Podczas gdy w tradycyjnych badaniach traffic dane na temat ruchu dostępne są zazwyczaj następnego dnia lub po godzinie, realtime traffic pozwala obserwować niekiedy zachowania pojedynczych internautów i szybkie zmiany trendów. Dla większości stron www ten rodzaj analizy stanowi pewien rodzaj ciekawostki. Jednak dla organizacji, które organizują duże punktowe wydarzenia (np. świąteczna akcja dobroczynna, koncert, program w ogólnopolskiej telewizji, organizowanie pomocy natychmiast po klęsce żywiołowej) analityka czasu rzeczywistego pomaga śledzić, co się dzieje teraz $i$ natychmiast na to reagować. W takim przypadku dochodzi do przeobrażenia roli analityki - z roli raportującej historię do roli obserwującej teraźniejszość.

Prototypowanie jest doskonałą metodą badań na etapie projektowania nowych produktów elektronicznych (stron, narzędzi internetowych, aplikacji mobilnych itd). W tradycyjnym, kaskadowym sposobie prowadzenia projektów tworzy się założenia, następnie powstaje szata graficzna i oprogramowanie, a kiedy projekt zbliża się do końca, dopiero wtedy dopuszcza się użytkowników do pierwszych testów. Gdyby okazało się, że rezultat nie odpowiada oczekiwaniom, zmiana założeń projektu wiąże się z ogromnymi kosztami. Prototypowanie pozwala uniknąć tego rodzaju pułapki dzięki iteracyjnemu (przyrostowemu) podejściu. Na wczesnym etapie prac, tworzy się przy pomocy flamastrów i nożyczek lub programów do prototypowania zarys koncepcji i natychmiast bada się reakcje przyszłych użytkowników na ten pomysł. Metoda ta jest niezwykle prosta i niemal bezkosztowa, daje jednak wysokiej jakości efekty, dzięki wczesnemu uwzględnieniu opinii odbiorców. Dla organizacji społecznych taki sposób działania nie tylko pomaga w uzyskaniu dobrej jakości ale pozwala też uniknąć kosztownych błędów w projektach dzięki wczesnemu sygnałowi zwrotnemu.

Testy A/B stały się jednym z najważniejszych narzędzi elektronicznego marketingu, ale mogą się okazać nie mniej użyteczne także dla trzeciego sektora. Ta eksperymentalna metoda sprowadza się do wykonania dwóch wersji danego projektu (banera reklamowego, formularza do wypełnienia itd.), a następnie opublikowania obu wersji i zmie-

18 Por. A. Kaushik, Godzina dziennie z Web Analytics. Stwórz dobrą strategię e-marketingową, Gliwice 2009. 
rzenia skuteczności każdej z nich. Zamiast więc dyskutować nad wyższością jednej koncepcji nad drugą, udowadnia się eksperymentalnie, która dała lepszy efekt. Wymaga to przygotowania dwóch wersji komunikatu, co nieco podnosi koszty, ale ostatecznie testy A/B pozwalają na wielką oszczędność, dzięki empirycznemu sprawdzeniu i porównaniu efektywności przekazu.

Ciekawym wyzwaniem dla organizacji non-profit wydają się badania publiczności (audience). Istotą tych badań jest prowadzenie ich dla całego rynku tą samą metodą przez zewnętrzny, obiektywny i niezależny podmiot. Pozwala to na przedstawienie charakterystyki całego rynku oraz porównanie tą samą metodą poszczególnych graczy. W branży medialnej badanie to odgrywa olbrzymią rolę, ponieważ pozwala ocenić realny zasięg poszczególnych wydawców, często rywalizujących ze sobą o większy zasięg, a co za tym idzie, o większe wpływy z reklamy. Zarówno organizacje społeczne jak też sektor rządowy nie wykazują zainteresowania tego typu badaniami. Wydaje się tymczasem, że wprowadzenie tego typu badań pozwalałoby tym instytucjom lepiej rozumieć, jaka jest ich realna siła oddziaływania w porównaniu do innych graczy. Proste statystyki internetowe typu traffic albo liczniki polubień w serwisach społecznościowych mogą powodować subiektywne przeszacowanie siły własnego podmiotu, czego przykładem jest częste przecenianie tzw. liczby użytkowników cookies oraz liczby polubień na Facebooku.

Ankieta jest klasycznym narzędziem sondażowym w badaniach społecznych, może też być wykorzystywana w internecie. Stosunkowo łatwo można zachęcić odwiedzających stronę www, czytelników newslettera lub fanów profilu w serwisie społecznościowym do jej wypełnienia. Ankieta internetowa pozwala między innymi na zebranie pogłębionej informacji na temat profilu społeczno-demograficznego czytelników, ale też umożliwia sprawne przeprowadzenie sondażu w kwestiach, które są przedmiotem działania danej organizacji.

Badanie SEO jest zbiorem różnorodnych technik, służących do poprawienia widzialności strony w wyszukiwarkach internetowych. W tym celu mierzy się widoczność strony dla różnych słów kluczowych, analizuje się techniczną poprawność budowy strony, linki wewnętrzne i zewnętrzne, bada się charakterystykę artykułów i grafik oraz przeprowadza wiele innych testów. ${ }^{19}$ Omawianie metodologii badań SEO znacznie wykracza poza tematykę tego artykułu. W tym miejscu należy tylko podkreślić, że badanie SEO i optymalizacja treści strony w oparciu o wnioski pozwala na pozyskanie większej liczby czytelników, większej liczby odsłon oraz dotarcie ze swoim przekazem do większej liczby osób zainteresowanych tematem (czego wyrazem jest wpisanie słowa kluczowego w wyszukiwarce). Wydaje się, że ten rodzaj aktywności, polegający na komunikowaniu społeczeństwu swoich celów, należy do podstawowej działalności organizacji w trzecim sektorze.

Analiza heurystyczna (ekspercka) pomaga w poprawieniu jakości produktu elektronicznego. Badanie przeprowadzane jest jednoosobowo przez eksperta $w$ dziedzinie tworzenia produktów elektronicznych, który na podstawie własnego doświadczenia lub gotowej bazy dobrych praktyk przygotowuje listę uwag.

19 Por. T. Frontczak, Marketing internetowy w wyszukiwarkach, Gliwice 2006. 
Wywiad indywidualny, choć wymaga już nieco większych przygotowań, jest najważniejszą jakościową metodą badań w internecie. Kilka osób, odpowiadających profilowi odbiorców, zaprasza na pogłębione rozmowy, podczas których przegląda stronę, dzieląc się uwagami. Często też wykonuje jakieś zadanie, typowe dla aktywności na tej stronie, co pozwala stwierdzić, czy strona jest łatwa w użytkowaniu. Wywiad jest zazwyczaj rejestrowany ( $\mathrm{w}$ formie screencastu, czyli nagrania ekranu z komentarzem dźwiękowym, lub pełnego nagrania z kamery). Z wywiadów sporządza się raport końcowy zawierający podsumowanie i rekomendację. Niektóre firmy badawcze preferują prowadzenie tego badania w bardzo rozbudowanej formie (specjalne studio badawcze, kamery, lustro weneckie), jednak możliwe jest przeprowadzenie tego badania minimalnym kosztem z równie dobrym skutkiem - potrzebny jest jedynie komputer, mikrofon i najprostszy program do rejestrowania ekranu. Jakob Nielsen, jeden z pionierów badań internetu, uważa, że wywiad przeprowadzony na pięciu osobach pozwala zidentyfikować większość usterek na stronie. ${ }^{20}$

Dobrym przykładem strony, na której można testować prowadzenie wywiadu indywidualnego, jest strona polskiej Caritas (www.caritas.pI). Strona ta przeszła wiele przeobrażeń w ciągu ostatnich kilkunastu lat. Ponieważ przez kilka lat prowadziłem ze studentami specjalizacji internetowej UKSW badanie indywidualne tego serwisu, przytoczę kilka najważniejszych wniosków, tytułem egzemplifikacji.

Podczas badań przyjęliśmy, że jedną z najważniejszych funkcji takiej strony, jest umożliwienie darczyńcom przekazania środków na rzecz Caritas (lub szybkie znalezienie informacji o tym, jak można to zrobić). Dlatego głównym elementem badania było zadanie o następującej treści: „Chciałbyś przekazać pieniądze na rzecz Caritas. Zrób to poprzez stronę lub znajdź informację, jak to zrobić”. Badanie było powtarzane co roku z kolejnymi grupami studentów, w międzyczasie sama strona Caritas przeszła kilkukrotnie metamorfozę. W ciągu ostatniej dekady zauważyliśmy wyraźne skrócenie czasu potrzebnego na wykonanie zadania. Jeszcze kilka lat temu testowane osoby potrzebowały niekiedy nawet dwóch minut na znalezienie stosownych informacji, nie obyło się bez trudności. Ostatni raz badanie zostało powtórzone w styczniu 2017 roku. Badana osoba potrzebowała mniej niż 5 sekund na wykonanie zadania, a w przeciwieństwie do starszych wersji, strona udostępniała nie tylko numer konta, ale umożliwiała też natychmiastowe przelanie środków za pomocą internetowego przelewu. Przykład ten dowodzi, jak bardzo praktyczne mogą być wyniki wywiadu indywidualnego i jak przydatne są organizacjom należącym do trzeciego sektora.

\section{Podsumowanie}

Skuteczna komunikacja w internecie wymaga, by publikowaniu w Sieci towarzyszyło badanie jej efektów. Zasada ta została uznana w sektorze firm prywatnych, stopniowo jest asymilowana w sektorze państwowym, ale istnieje potrzeba uznania wartości badań

20 Por. J. Nielsen, Why You Only Need to Test with 5 Users, https://www.nngroup.com/articles/why-you-only-need-to-test-with-5-users/ [dostęp: 2017-11-05]. 
także w odniesieniu do organizacji typu non-profit. W badaniach w dziedzinie Business Intelligence już przed laty wykazano, że istnieje ścisły związek między dojrzałością analityczną organizacji a jej sprawnością działania. Firmy, które zaczęły gromadzić dane, stopniowo uczą się ich interpretacji, by najpierw zrozumieć swoje położenie, a w kolejnych etapach przewidywać nadchodzące trendy i prognozować skutki swoich działań. Pod wpływem badań organizacje stają się inteligentne, potrafią wyciągać wnioski z danych, podejmują lepsze decyzje, uczą się prognozować; dzięki danym szybciej wyłapują zagrożenia i łatwiej znajdują szanse rozwoju.

Dla organizacji trzeciego sektora analityka internetowa, choć jeszcze niedoceniania, może odgrywać kluczowe znaczenie, bo to właśnie dla stowarzyszeń i fundacji od umiejętnej komunikacji z otoczeniem zależy w dużym stopniu ich sprawność działania. Dla tych organizacji zdolność do bardzo efektywnego działania przy ograniczonych środkach ma kluczowe znaczenie i może być osiągana między innymi dzięki zbieraniu i analizowaniu danych.

$\mathrm{Z}$ badania pilotażowego, polegającego na przeanalizowaniu stron internetowych organizacji pożytku publicznego oraz stron diecezji rzymskokatolickich w Polsce, powtórzonych w latach 2015 i 2017, wynika, że chociaż w obu przypadkach instytucje te wykazują zainteresowanie komunikacją w internecie, jedynie co czwarta organizacja pożytku publicznego (bez zmian w ciągu dwóch lat) i $62 \%$ diecezji mierzy zachowanie swoich użytkowników na stronie (wzrost o 10 puntów procentowych w ciągu dwóch lat) za pomocą standardowych narzędzi pomiarowych. Dane te prowadzą do wniosku, że znacząca część trzeciego sektora w dalszym ciągu traktuje internet bardziej jako tablicę ogłoszeń niż jako narzędzie komunikacji, dostarczające sygnał zwrotny. W świetle obecnej wiedzy na temat skuteczności komunikacji w internecie, takie podejście wydaje się nieoptymalne. Korzystając z teorii dojrzałości analitycznej organizacji można bowiem stwierdzić, że mniej niż połowa diecezji i trzy czwarte organizacji pożytku publicznego nie osiągnęło nawet pierwszego stopnia dojrzałości analitycznej (zbieranie danych).

W trzeciej części artykułu zaproponowałem dziesięć klasycznych i sprawdzonych technik badania internetu, pokazując możliwości ich zastosowania przez organizacje typu non-profit. Propozycja ta nie ma zamkniętego charakteru, istnieje bowiem wiele innych technik badawczych, a ostateczny zestaw narzędzi powinien być dostosowany do konkretnej organizacji. Wydaje się jednak, że dla trzeciego sektora, który chętnie korzysta z dobrodziejstw internetu, rozwinięcie kompetencji w dziedzinie analityki internetowej może otworzyć nowe możliwości coraz bardziej skutecznego działania. Duża część z tych, często lokalnych i niewielkich, organizacji prawdopodobnie nie dojdzie do posiadania dużych zbiorów danych, ich rozwój nie będzie więc polegał na dążeniu do „Big Data”, a raczej do „Smart Data” - zdolności do tworzenia wiedzy z danych i uczenia się otoczenia na podstawie informacji zwrotnej.

Na koniec należy zwrócić uwagę, że temat analityki internetowej w trzecim sektorze nie został dotychczas wystarczająco zbadany. Aspiracją autora nie było wyczerpanie tematu, ale raczej wywołanie go i zachęta do dalszych poszukiwań, ze względu na istotną rolę organizacji non-profit dla rozwoju społeczeństwa. 


\section{BIBLIOGRAFIA}

Beasley M., UX i analiza ruchu w sieci. Praktyczny poradnik, Gliwice 2014.

Biecek P., Jak kształcić Data Scientists / Badaczy Danych?, http://smarterpoland.pl/index.php/2015/11/jak-ksztalcic-data-scientists-badaczydanych/ [dostęp: 2017-11-04].

Davenport Th. H., Harris J. G., Inteligencja analityczna w biznesie. Nowa nauka zwyciężania, Warszawa 2010.

Frontczak T., Marketing internetowy w wyszukiwarkach, Gliwice 2006.

Kaushik A., Godzina dziennie z Web Analytics. Stwórz dobrą strategię e-marketingową, Gliwice 2009.

Kaushik A., Web Analytics 2.0. Świadome rozwijanie witryn internetowych, Gliwice 2010.

Keen A., Kult amatora. Jak internet niszczy kulturę, Warszawa 2007.

Krug S., Nie każ mi myśleć. O życiowym podejściu do funkcjonalności stron internetowych, Gliwice 2010.

Mayer-Schönberger V., Cukier K., Big Data, Warszawa 2014.

McQuail D., Teoria komunikowania masowego, Warszawa 2008.

Miotk A., Skuteczne social media, Gliwice 2017.

Mościchowska I., Rogoś-Turek B., Badania jako podstawa projektowania user experience, Warszawa 2015.

Nielsen J., Projektowanie funkcjonalnych serwisów internetowych, Gliwice 2003.

Nielsen J., Tahir M., Funkcjonalność stron WWW. 50 witryn bez sekretów, Gliwice 2006.

Nielsen J., Why You Only Need to Test with 5 Users, https://www.nngroup.com/articles/why-you-only-need-to-test-with-5users/ [dostęp: 2017-11-05].

Silverman D., Prowadzenie badań jakościowych, Warszawa 2010.

Tapscott D., Williams A. D., Wikinomia. O globalnej współpracy, która zmienia wszystko, Warszawa 2008.

Toffler A., Trzecia fala, Warszawa 2006.

Wimmer R. D., Dominick J. R., Mass media. Metody badań, Kraków 2008.

\section{O AUTORZE:}

dr Marek Robak - adiunkt w Katedrze Internetu i Komunikacji Cyfrowej UKSW. Specjalizuje się w komunikacji internetowej, technologii informacyjnej mediów, metodologii badań internetu i bezpieczeństwie informacji. Prowadził duże projekty internetowe m.in. dla firmy badawczej Gemius, dziennika „Puls Biznesu”, Katolickiej Agencji Informacyjnej oraz organizacji społecznych i rządowych. Członek-założyciel Internet Society Poland. Twórca specjalizacji internetowej na UKSW, wykładał też w Wyższej Szkole Dziennikarskiej im. Melchiora Wańkowicza. Kontakt:m.robak@uksw.edu.pl 
KuLTura- MeDia- TeoLogia

ISSN 2081-8971

$2017 \mathrm{nr} 30$, s. 70-100.

Karolina Świrska-Czałbowska -Instytut Edukacji Medialnej i Dziennikarstwa, Uniwersytet Stefana Kardynała Wyszyńskiego

\section{Obraz Polski i Polaków w europejskim dyskursie publicznym. Analiza wyników badań opinii publicznej i artykułów z prasy zachodniej w latach 2004-2017}

\section{The image of Poland and Poles in the European public discourse. Analysis of the results of polls and articles from the Western press in 2004-2017.}

\section{STRESZCZENIE:}

Celem artykulu jest pokazanie wizerunku Polski

I POLAKÓW W KRAJACH „STAREJ UNII” ORAZ ZANALIZOWANIE JAK POLACY BYLI OCENIANI PRZED AKCESJĄ DO UNII EUROPEJSKIEJ W 2004 ROKU I JAK SĄ POSTRZEGANI OBECNIE. NINIEJSZE STUDIUM PRÓBUJE POKAZAĆ, CZY W WYNIKU WEĄCZENIA POLSKI DO STRUKTUR EUROPEJSKICH WIZERUNEK NASZEGO KRAJU SIE ZMIENIE I NA ILE; JAK NASZA PONAD 13 LETNIA OBECNOSĆ W STRUKTURACH UNIJNYCH WPEYWA NA POSTRZEGANIE NASZEGO KRAJU ZARÓWNO WŚRÓD ELIT POLITYCZNYCH PAŃSTW UNIJNYCH, JAK I ZWYKŁYCH OBYWATELI. WYKORZYSTANE SĄ BADANIA OPINII PUBLICZNEJ, POLSKIE I MIĘDZYNARODOWE, JAK RÓWNIEŻ ARTYKUŁY PRASOWE, GŁÓWNIE Z PRASY ANGLOJĘZYCZNEJ.

\section{SEOWA KLUCZOWE:}

INTEGRACJA EUROPEJSKA, WIZERUNEK POLSKI, STEREOTYPY KULTUROWE, DYNAMIKA ZMIAN

\section{ABSTRACT:}

THE CONCEPT OF THIS PAPER IS TO PRESENT HOW POLAND AND POLISH PEOPLE WERE PERCEIVED IN "OLD" EU COUNTRIES PRIOR TO POLISH ACCESSION TO EUROPEAN UNION AND HOW POLISH PEOPLE WERE EVALUATED IN A CONTEXT OF "EASTERN ENLARGEMENT". ARTICLE ATTEMPTS TO FIND AN ANSWER WHETHER DUE TO POLISH INCLUSION IN EUROPEAN INSTITUTIONS, IMAGE OF POLAND HAS CHANGED AND HOW MUCH; HOW 13 YEARS LONG PRESENCE IN EU STRUCTURES INFLUENCED PERCEPTION OF OUR COUNTRY BOTH AMONGST EU POLITICAL ELITES AS WELL AS ORDINARY CITIZENS. THERE ARE USED BOTH PUBLIC OPINION POLLS, POLISH AND INTERNATIONAL, AS WELL AS PRESS ARTICLES, MAINLY FROM THE ENGLISH-LANGUAGE PRESS.

\section{KEYWORDS:}

EUROPEAN INTEGRATION, Polish IMAGE, CULTURAL STEREOTYPES, DYNAMICS OF CHANGE 
„Europa to coś dalekiego, co trzeba osiągnąć, a co trzeba jeszcze zasłużyć....

To też coś cennego i z klasą: elegancki strój, szczególny wygląd i nawet zapach ludzi...."

Slavenka Drakulić „Cafe Europa”

$\mathrm{P}$ olska stała się członkiem Unii Europejskiej w maju 2004 roku. Dla społeczeństw dawnych krajów Unii, tak jak dla ich rządów, już od dawna było oczywiste, że rozszerzenie jej granic na wschód Europy postawi przed nią nowe wyzwania. Zmianom miała ulec sama Unia Europejska w ówczesnym kształcie, jak również zasady jej funkcjonowania, co powodowało spore obawy wśród mieszkańców wielu państw unijnych. Obawy i wątpliwości były obecne po obu stronach - zarówno po stronie krajów kandydackich, jak i krajów dawnej UE-15. Dlatego warto starać się pokazać, jaki był wizerunek Polski i Polaków w krajach „starej Unii” na tle uwarunkowań „wschodniego rozszerzenia”, a także odpowiedzieć na pytanie, jak zmienił się on w wyniku włączenia Polski do struktur europejskich.

Wcześniejsze rozszerzenia - „północne” z 1973 roku, „południowe” z 1981 i 1986 roku oraz „państw neutralnych” z 1995 roku nie wzbudzały tylu kontrowersji. Do silnej i bogatej Unii weszły kraje nieróżniące się znacznie od państw członkowskich poziomem zamożności i rozwoju cywilizacyjnego (w szczególności przy rozszerzeniu „północnym” i „państw neutralnych” różnice nie były tak istotne). Przy okazji rozszerzenia „wschodniego” z 2004 roku sytuacja była inna: do Unii dołączyły kraje, które dopiero kilkanaście lat wcześniej weszły na zachodnią ścieżkę rozwoju i wciąż nie dorównywały państwom unijnym ani pod względem stanu gospodarki, ani dojrzałości politycznej, czy politycznych tradycji.

Również kryteria oceny państw kandydatów zostały poddane wielu zmianom i weryfikacjom. Jak pisała Lena Kolarska-Bobińska w przededniu integracji: „coraz większą rolę w procesie integracji zaczyna też odgrywać polityka oraz 'miękkie', pozaprawne kryteria oceny kandydatów, niepisane i zmieniające się racje, u podłoża których często leżą stereotypy krajów i społeczeństw, czy tradycje historycznych relacji między państwami. W tej sytuacji kluczowe staje się określenie, jaki wizerunek Polski i Polaków funkcjonuje obecnie w krajach Unii, gdyż sprzyja to prowadzeniu właściwej polityki informacyjnej i lobbingu, jak również dlatego, że integracja oznacza przede wszystkim bliskie współdziałanie społeczeństw, regionów, organizacji. (...) Sposobem poprawy pozycji naszego kraju jest zmiana wizerunku Polski. Postrzeganie rzeczywistości odgrywa bowiem równie istotną rolę jak "twarde« fakty, wskaźniki i liczby”12.

Wally Olins - brytyjski specjalista od marketingu narodowego i szef Saffron Brand Consultants - firmy, która wraz z Instytutem Marki Polskiej pracowała nad zmia-

\footnotetext{
${ }^{1}$ L. Kolarska-Bobińska, Obraz Polski i Polaków w Europie, wyd. Instytut Spraw Publicznych, Warszawa 2003, s. 10.

${ }^{2}$ W. Olins, Tożsamość rynkowa. Atrybut konkurencyjnego Państwa, wyd. Instytut Marki Polskiej, Warszawa 2001, s. 133-164.
} 
ną wizerunku Polski twierdził, że dobra marka przedsiębiorstwa jest częścią jego majątku, wartością przeliczaną na zysk. Również przemyślany oraz dopracowany wizerunek kraju pełni kluczową rolę w gospodarczych i politycznych kontaktach między państwami. Bez niego trudno jest zdobyć zaufanie inwestorów zagranicznych i zaistnieć na arenie międzynarodowej. Główne tezy Olinsa są następujące:

1. W dzisiejszym świecie są trzy najważniejsze płaszczyzny gospodarczej rywalizacji między państwami: pozyskiwanie inwestycji zagranicznych, turystyka oraz eksport towarów i usług.

2. Zdecydowana większość krajów i regionów, które zdołały przyciągnąć inwestycje zagraniczne realizowała przemyślane strategie promocyjne, kreując planowo swój wizerunek (przykład Walii i Irlandii).

3. Stereotypy dotyczące kraju mogą w znacznym stopniu wpływać na możliwość rozwoju państw. Zbudowanie 'pozytywnego stereotypu' może uczynić miejsce pochodzenia produktu atutem wzabieganiu o rynki zbytu (Brazylia).

4. W turystyce panuje ogromna konkurencja cenowa. Nie wystarcza już atrakcyjne położenie geograficzne ani piękno natury - kraje próbujące przyciągnąc turystów muszą się wyróżniać. Używając tych samych technik, co producenci dóbr konsumpcyjnych, muszą pokazać to, co czyni je wyjątkowymi (Portugalia).

5. Państwa konkurują między sobą używając nowoczesnych narzędzi marketingowych. Sukces komercyjny zależy do tego, czy wizerunki dotyczące inwestycji zagranicznych, eksportu i turystyki są spójne, wzajemnie się spierają. Dlatego tak ważne jest planowanie, koordynacja i systemowe zarządzanie marką narodową (przykłady całościowej polityki wizerunkowej: Hiszpania, Wielka Brytania). ${ }^{3}$

Niestety, Polska w momencie akcesji do Unii nie mogła poszczycić się dobrym obrazem samej siebie ani u sąsiadów, ani u dalszych państw zachodniej Europy. I nie tylko Polska. Mimo, że po upadku systemu komunistycznego społeczeństwa krajów byłego bloku wschodniego zaczęły popierać idee demokratyczne, przez fatalny stan swojej gospodarki zyskały odrębny status od krajów Europy Zachodniej. Nawet w oficjalnym nazewnictwie Unii kraje Europy Środkowowschodniej zaczęto je określać jako „drugą Europę” („the other Europe”). Znalazło to wyraz w nastrojach podsumowujących politykę WE wobec krajów kandydackich. Andras Koves zauważył, że:

„Wspólnym problemem państw regionu Europy Środkowo-Wschodniej jest konieczność wspótistnienia i funkcjonowania watmosferze, którą uznają jako za stosunkowo lekceważącą. Wszystkie prognozy i podsumowania dają im odczuć, że nie są tak ważne dla reszty świata (który według ich światopoglądu oznacza Świat Zachodu), jakby sobie tego życzyły". ${ }^{4}$

\footnotetext{
${ }^{3}$ Tamże.
} 


\section{Wizerunek krajów Europy Środkowo-Wschodniej w krajach dawnej Unii Europejskiej (UE -15) w momencie akcesji do UE}

Dziedzictwo Europy Środkowo-Wschodniej utożsamiane było z dziedzictwem konfliktów i resentymentów (np. problem niemiecki), brakiem tradycji politycznej (t.j. pluralizm, debata), zacofaniem ekonomicznym (brak przedsiębiorczości, wtórność, a nie endogeniczność rozwoju). Różnice w kulturze politycznej (brak stabilności, częste zmiany rządów, konflikty pomiędzy społeczeństwem, a klasą polityczną) bardzo niekorzystnie wpływały na obraz krajów Europy Wschodniej. Te cechy sprawiły, że elity Zachodu po roku 1989 z nieufnością odnosiły się do elit politycznych Europy Wschodniej. Sytuację porównywano do pierwszych lat powojennych w Niemczech i Włoszech, kiedy brakowało tam porządku i harmonii w życiu publicznym, a zmęczone wojną społeczeństwa wykazywały sympatie w kierunku sił antydemokratycznych.

Zasadnicze różnice i niedociagnięcia, jakie wypominano krajom Europy ŚrodkowoWschodniej można podzielić na polityczno-społeczne, gospodarcze i infrastrukturalne.

Do kwestii polityczno- społecznych zaliczano: odmienność kultury politycznej, brak stabilizacji na scenie politycznej, brak zaufania do elit politycznych - jako dziedziców postkomunizmu i niewiarygodnych partnerów do dyskusji, również nieprzewidywalność opinii publicznej. Kolejną kwestią miała być przestarzała struktura społeczna i zawodowa Polski, powstała w wyniku dominacji gospodarki nakazowo-rozdzielczej, która nie przystawała do wymagań gospodarki kapitalistycznej i wolnego rynku. Uznano, że zbyt wysoka liczba osób pracuje w sektorze rolnictwa i przemysłu, przy niskiej roli sektora usług, a także zawodów nowoczesnych (tj. biznes, bankowość, ubezpieczenia, obrót nieruchomościami, itp.). Przestarzałe i mało wydajne polskie rolnictwo wymagać miało nie tylko dużych nakładów z Unii, ale i ze środków własnych Polski. Wskazywano również rozbudowane państwowe systemy biurokratyczne, niskie płace pracowników, niską siłę nabywczą ludności, pasywny stosunek do pracy. ${ }^{5}$ Warunki wymagane przez rynek europejski wymusić miały modernizację struktury zawodowej polskiego społeczeństwa, co spowodować miało dodatkowe koszty społeczne.

Do różnic gospodarczych zaliczano: przestarzałą strukturę gospodarki, produkcję przemysłową ocenianą na 30-50\% poniżej standardów wymaganych w państwach UE -15, nadmierne zużycie materiałów i energii, zyskowność produkcji znacznie niższą niż na Zachodzie, niestabilne rynki finansowe. Wskazywano także na braki nowoczesnej infrastruktury: zbyt mała liczba dróg, niedorozwój transportu śródlądowego i lotniczego, zły stan sieci telekomunikacyjnych, a także lekceważenie zasad ochrony środowiska.

Kolejną barierą było niedostosowanie prawa do reguł gospodarki rynkowej i zadłużenie zagraniczne, które w roku 1989 w przypadku krajów Europy Środkowo-Wschodniej wy-

\footnotetext{
${ }^{4}$ A. Koves, Central and Eastern European Economies in Transition. The International Dimension, Westview Press, San Francisco 1992.

${ }^{5}$ Szerzej por. E. Wnuk-Lipiński, Członkostwo Polski w Unii Europejskiej-pierwsze Problemy i kryzysy spoleczne w Polsce, w: Polska w Unii Europejskiej. Początkowe problemy i kryzysy?, wyd. PISM Warszawa 2002.
} 
liczono na 99,2 mld dolarów (zadłużenie Polski szacowano na 40,4 mld dolarów i 1078 dolarów per capita, Węgier 19,7 mld dolarów i 1873 dolarów per capita, a Czechosłowacji 6,9 mld dolarów i 431 dolarów per capita). ${ }^{6}$ Obawiano się również, że dla polskich firm barierą uniemożliwiającą wejście dla ich produktów na europejskie rynki będą unijne standardy jakości, którym sprostanie nie będzie możliwe bez uprzednich zmian modernizacyjnych i nakładów inwestycyjnych. Ważne były również kwestie gospodarki terenów przygranicznych, zwłaszcza ściany wschodniej, która przez odcięcie i uszczelnienie granicy miała zostać pozbawiona stałej możliwości zarobkowania. Ukrócenie „,szarej strefy” handlu przygranicznego miało dla terenów ściany wschodniej okazać się ciosem w ich interesy ekonomiczne i spowodować opór tej części ludności przeciwko dalszym zmianom.

Wszystkie te problemy opóźniały negocjacje i przyjęcie krajów Europy ŚrodkowoWschodniej do Unii Europejskiej. Dano im do zrozumienia, że zgoda na ich członkostwo w Unii zależna będzie od stanu przygotowań i spełnienia warunków polityczno-gospodarczych wyznaczonych przez UE.

Jakie wobec tego czynniki przemawiały za przyjęciem tych krajów do UE?

Wskazywano na wzrost zagrożenia bezpieczeństwa w Europie jako efekt zaniechania współpracy z krajami Europy Środkowo-Wschodniej. Obawiano się wybuchu konfliktów i rozruchów w tej części Europy oraz zakładano, że rządy Zachodu będą zmuszone w nie zaingerować. Za bliższą współpracą przemawiała również perspektywa zdobycia rynku kilkudziesięciu milionów nowych konsumentów dla produktów zachodnioeuropejskich i tańszej siły roboczej dla europejskiego przemysłu. Korzyści, wypływające ze zwiększonej wymiany handlowej i ze wzrostu gospodarczego w krajach wschodnich miały być widoczne w całej Europie, nie tylko w krajach nowoprzyłączonych. Nie bez znaczenia były związki kulturowe i historyczne państw Europy Środkowo-Wschodniej, przemawiające za przyłączeniem ich do Unii. Uważano, że Unia, dysponująca liczbą 25 członków zwiększyłaby jeszcze swój potencjał polityczny na arenie międzynarodowej.

\section{„Witajcie w Unii, jeśli musicie”, czyli społeczeństwa dawnych krajów członkowskich wobec poszerzenia} Ponieważ akceptacja dla procesu integracji w państwach członkowskich była jednym z celów polityki informacyjnej UE, regularnie prowadzono badania monitorujące stosunek do procesu integracji w społeczeństwach dawnych i nowych krajów UE. Jak opisywał prof. J. Holzer „punktem wyjścia dla analiz wzajemnych wizerunków powinna być daleko posunięta asymetria. Kultura, przemiany polityczne i cywilizacyjne krajów Europy Zachodniej były i są u nas obserwowane i analizowane z dużym zainteresowaniem. Natomiast kultura polska i zmiany, jakie na bieżąco zachodzą w Polsce, jak również innych krajach wyszehradzkich traktowane były na zachodzie w zainteresowaniach marginalnie, raczej jako element egzotyki niż równoprawnego sąsiedztwa". ${ }^{7}$

Społeczeństwa dawnych krajów członkowskich Unii, zupełnie inaczej niż społeczeństwa krajów aspirujących do Unii postrzegały przyjęcie do niej krajów Europy Wschodniej.

6 Cyt. za: B. Płonka, Polityka Unii Europejskiej wobec krajów Europy Środkowej, wyd. UJ Kraków 2003, s. 59.

${ }^{7}$ J. Holzer, Polacy i Niemcy - wzajemne postrzeganie, Kultura i społeczeństwo, tom XLI, wyd. ISP PAN 1997. 
Tab.1. Problematyka dotycząca rozszerzania Unii Europejskiej

\begin{tabular}{|l|l|l|l|}
\hline Twierdzenie & Zgadzam się & $\begin{array}{l}\text { Nie zgadzam } \\
\text { się }\end{array}$ & $\begin{array}{l}\text { Trudno po- } \\
\text { wiedzieć }\end{array}$ \\
\hline $\begin{array}{l}\text { Im więcej państw będzie należeć do Unii, tym większe będzie } \\
\text { jej znaczenie w świecie }\end{array}$ & $67 \%$ & $17 \%$ & $16 \%$ \\
\hline $\begin{array}{l}\text { Mając więcej członków w Unii, Europa będzie bogatsza kultu- } \\
\text { ralnie }\end{array}$ & $61 \%$ & $31 \%$ & $8 \%$ \\
\hline $\begin{array}{l}\text { Większa liczba członków oznacza większa gwarancję pokoju } \\
\text { i bezpieczeństwa w Europie }\end{array}$ & $59 \%$ & $25 \%$ & $16 \%$ \\
\hline $\begin{array}{l}\text { Przed włączeniem nowych członków Unia musi zreformować } \\
\text { działalność swoich instytucji }\end{array}$ & $59 \%$ & $16 \%$ & $25 \%$ \\
\hline $\begin{array}{l}\text { Rozszerzenie Unii o nowych członków oznacza zmniejszenie } \\
\text { pomocy finansowej dla mojego kraju }\end{array}$ & $47 \%$ & $26 \%$ & $27 \%$ \\
\hline $\begin{array}{l}\text { Im więcej krajów znajdzie się w Unii, tym większe bezrobocie } \\
\text { w moim kraju }\end{array}$ & $35 \%$ & $41 \%$ & $24 \%$ \\
\hline $\begin{array}{l}\text { Powiększenie Unii o nowe kraje oznacza zmniejszenie znacze- } \\
\text { nia mojego kraju w Europie }\end{array}$ & $34 \%$ & $47 \%$ & $19 \%$ \\
\hline $\begin{array}{l}\text { Powiększenie Unii nie oznacza większych kosztów dla obec- } \\
\text { nych jej członków }\end{array}$ & $28 \%$ & $49 \%$ & $23,00 \%$ \\
\hline
\end{tabular}

Żródło: Eurostat Yearbook 2001. The Statistical Guide to the Europe, Data 1989-1999 ${ }^{8}$.

Z twierdzeniem 'im większa liczba krajów w Unii, tym większe bezrobocie' zgodziło się 51\% Austriaków, 47\% Niemców i 46\% Greków. Na pytanie o koszty dla macierzystego kraju w związku z poszerzeniem Unii twierdząco odpowiedziało 62\% Holendrów, 60\% Niemców i 58\% Austriaków. Obywatele Irlandii (68\%), Danii (62\%), Grecji i Finlandii (po 61\%) obawiali się ograniczenia pomocy finansowej w związku z rozszerzeniem, jednak odsetek osób aprobujących akcesję nowych krajów członkowskich był największy właśnie w Danii, Grecji, Holandii, Finlandii i Szwecji. Wyniki aprobaty uzyskane w Belgii, Francji i Luksemburgu były dużo niższe.

Dało się zaobserwować również wyraziste sympatie lub antypatie dla poszczególnych kandydatów. Grecy silnie popierali wejście Cypru do Unii (88\% poparcia), a np. Austriacy i w Niemcy niechętnie widzieli w Unii Rumunię (14\% poparcia w Austrii i 17\% w Niemczech). Również widoczny był spadek poparcia dla przyjęcia takich krajów jak Polska i Węgry ${ }^{9}$.

Społeczeństwa dawnych krajów unijnych najchętniej widziałyby we Wspólnocie Norwegię i Szwajcarię, jako bogate kraje o wysokim poziomie rozwoju cywilizacyjnego, do których nie trzeba będzie dopłacać. Późniejsze badania społeczne dowodziły, że tendencja spadkowa sympatii dla poszerzenia na Wschód się utrzymała. Według badań Eurobarometru nr 59 z wiosny 2003 poparcie dla poszerzenia wśród społeczeństw krajów dawnej unijnej 15-tki wyglądało następująco:

\footnotetext{
${ }^{8}$ Por. www.eurostat.com.

${ }^{9}$ P.W. Walkiewicz, Polska na drodze do Unii Europejskiej. Aspekty negocjacyjne i dostosowawcze, wyd. Rzeszów 2002, s. 57, także szerzej por. How Europeans see themselves: looking through the mirror with public opinion surveys, European Commission, Luxemburg 2001.
} 
Tab. 2. Kraje Unii wobec wschodniego rozszerzenia.

\begin{tabular}{|l|l|l|l|}
\hline Kraj & Za $(\%)$ & Przeciw $(\%)$ & Trudno powiedzieć (\%) \\
\hline Szwecja & 56 & 34 & 10 \\
\hline Finlandia & 50 & 40 & 10 \\
\hline Holandia & 48 & 38 & 14 \\
\hline Irlandia & 60 & 19 & 21 \\
\hline Wielka Brytania & 36 & 36 & 28 \\
\hline Dania & 63 & 25 & 12 \\
\hline Belgia & 38 & 44 & 18 \\
\hline Luksemburg & 53 & 40 & 7 \\
\hline Niemcy & 42 & 39 & 19 \\
\hline Austria & 43 & 44 & 13 \\
\hline Francja & 31 & 54 & 15 \\
\hline Hiszpania & 60 & 17 & 23 \\
\hline Portugalia & 60 & 22 & 18 \\
\hline Włochy & 59 & 22 & 19 \\
\hline Grecja & 71 & 19 & 10 \\
\hline
\end{tabular}

Źródło: Eurobarometr nr 59, wiosna 2003.

Wyraźnie widać było znaczący spadek ilości zwolenników wobec poszerzenia Unii na Wschód. W Belgii liczba przeciwników zjednoczenia kontynentu przekroczyła liczbę zwolenników. Podobnie stało się we Francji i Austrii. Duże spadki poparcia wystąpiły również w Finlandii, Holandii i Niemczech. We Francji, kraju o tradycyjne silnych nastrojach antyamerykańskich udział Polski w niepopularnej w Europie wojnie skomentował Jacques Chirac: „te kraje (kraje Europy Wschodniej) straciły szansę siedzenia cicho" ${ }^{10}$ Co jakiś czas pojawiały się komentarze prasowe opisujące rosnącą niechęć krajów członkowskich wobec przyjmowania nowych państw: „Witajcie w Unii, jeśli musicie”"11, „Wejście po przejściach”"12, „Ekonomiczny apartheid”13, „Żadnych złudzeń” ${ }^{14}$.

W 2001 r głośnym echem odbił się raport z badań jakościowych przygotowany przez francuską agencję badawczą OPTE na zlecenie Komisji Europejskiej „Obraz Unii Europejskiej, postaw i oczekiwań społecznych w 15 krajów członkowskich i 10 państwach kandydujących”. Badania odbywały się we współdziałaniu z lokalnymi agencjami badawczymi; ich celem było poznanie wzajemnych sposobów postrzegania się oby-

\footnotetext{
${ }^{10}$ T. Blankley, France blackmails Poland, "The Washington Times” 19.02.2002.

${ }^{11}$ J. Bielecki, A. Stankiewicz, Witajcie w Unii, jeśli musicie, „Rzeczpospolita” 26.04.2002.

${ }^{12}$ K. Bachman, Wejście po przejściach, „Polityka” 20.07.2002.

${ }^{13}$ J. Saryusz Wolski, Ekonomiczny apartheid, „Die Welt” 28.11.2002.

${ }^{14}$ A. Dawidowski, Żadnych złudzeń, „Unia i Polska” 23.10.2000.
} 
wateli w dawnych państwach Unii i krajach kandydackich. Polska część badań zrealizowała agencja Badań Społecznych i Marketingowych BSM, a ich wynik został przedstawiony m.in. w serwisie informacyjnym PAP. ${ }^{15}$

W raporcie Polacy zostali opisani w sposób, który może być uznany za obraźliwy. Oto zestaw cytatów z tego obszernego 200 stronicowego opracowania:
„Polacy boją się, że na zawsze pozostaną ubogimi krewnymi, nieznanymi i lekceważonymi (s.12). Obawy przeważają nad nadziejami, których z powo- du wyjątkowego pesymizmu nie są w stanie wyrazić (s.17).
Polacy uważają się za biedaków, którzy nie maja pełnego prawa wstępu na salony bogatych. Ich słaba znajomość języków obcych ogranicza im możli- wość kontaktów. W istocie cechuje ich kompleks niższości związany z nega- tywnym obrazem Polaków za granicą - oszustów i złodziei (...). Do tego do- chodzi żywe poczucie narodowości, które wreszcie po może znaleźć ujście po latach okupacji i zaborów. Ich poczucie godności ma przede wszystkim cha- rakter obronny (s.47).
Dominuje wśród nich obraz Unii gospodarczej, zrzeszającej bogate kraje. Cele, które legły u jej podstaw nie są szerzej znane ani doceniane. Polacy mają skłonność do sprowadzania wszystkiego do kategorii ekonomicznych (s.80). ${ }^{16}$

Późniejsze badania nad wizerunkami krajów i narodów prowadził Instytut Spraw Publicznych w 2003 r. Obejmowały one prawie wszystkie kraje Europy Zachodniej (Austrię, Hiszpanię, Szwecję, Francje, Wielkiej Brytanię i Niemcy). Ich wyniki również pokazały, że w procesie negocjacyjnym Polska i inne kraje Europy Środkowo-Wschodniej nie były traktowane jako równorzędny partner. Większość badanych nie miała również żadnej opinii na temat ówczesnej Polski; dominująca niewiedza dotyczyła wszystkich strategicznych obszarów rozwojowych Polski. Jedynie 15\% obywateli Niemiec, Austrii i Hiszpanii oraz 18\% Francji miało świadomość, że u nas funkcjonuje gospodarka rynkowa, zaś 30\% Niemców i Austriaków oraz 25\% Francuzów uważało, że w Polsce panuje demokracja. 32\% Niemców i Austriaków deklarowało, że uważa nasz system parlamentarny za podobny do tego, który dominuje w Europie Zachodniej. ${ }^{17}$ Obraz Polski jako kraju kandydackiego rysował się jako zgoła odmienny od państw członkowskich UE:

„Państwa Europy Środkowo-Wschodniej postrzegane były w Unii jako odległe geograficznie i cywilizacyjne, odmienne pod względem ekonomicznym i politycznym od dotychczasowych członków. Polska jawiła się jako kraj nie-

\footnotetext{
${ }^{15}$ J. Dessler „Komisja Europejska o przywarach Polaków”, PAP lipiec 2001. <><

${ }^{16}$ „UE- Polak to pazerny fatalista”- serwis informacyjny Wirtualnej Polski z 25.07.2001, szerzej por. E. Skotnicka-Illasiewicz „Swojska kultura lękliwości. O sposobach postrzegania UE przez Polakówi unitów”, Unia i Polska 3.09. 2001.

${ }^{17}$ L. Kolarska-Bobińska „Odmienność oswajana. Obraz Polski w krajach Unii Europejskiej”, wyd. Instytut Spraw Publicznych, Warszawa 2003, s. 9-16
} 
podobny do kraju respondenta: katolicki i tradycyjny, zacofany, o silnej korupcji, nie najlepszej organizacji pracy i gospodarce niepodobnej do gospodarki krajów Unii Europejskiej. (...) Polska w oczach Zachodu wyzwoliła się spod komunizmu, ale jeszcze nie przezwyciężyła politycznych i ekonomicznych konsekwencji tego ustroju. Społeczeństwa zachodnie nie wiedzą jednak, w którym miejscu Polska się znajduje, jak daleko odeszła od komunizmu i kiedy upodobni się do państw Unii Europejskiej”. ${ }^{18}$

Również interesująco pod względem badawczym zapowiada się przyjrzenie się, jak unijni negocjatorzy postrzegali stronę polską w procesie akcesyjnym:

„Dla urzędników Komisji było oczywiste, że to kraje kandydujące są bardziej zainteresowane przystąpieniem do Unii oraz szybkim negocjowaniem umowy. Kraje wschodniego rozszerzenia, w porównaniu nawet do krajów rozszerzenia południowego były postrzegane jako kraje 'bez alternatywy'. (...) Wywoływało to dysonans w konfrontacji z żądaniową postawą przedstawicieli krajów kandydujących: 'Oni mają bardzo wysokie aspiracje, lecz bardzo skromne argumenty po swojej stronie'. (...) W przypadku Polski panowało charakterystyczne przekonanie o 'niekompatybilności jej interesów z Unią?'. W przeszłości podobnie była postrzegana Hiszpania. (...) Dla porównania kraje skandynawskie były uznawane za doskonale przygotowane, mające profesjonalną administrację, a przede wszystkim uważane za 'bogatych, dobrze znanych, bliskich przyjaciół'. Kandydaci 'wschodniego rozszerzenia' byli natomiast postrzegani jako biedni, dalecy kuzyni - 'pasażerowie drugiej klasy"'. ${ }^{19}$

Tak więc w momencie rozszerzenia Unii elity i społeczeństwa Europy Zachodniej postrzegały nas jako kraj zacofany i zapóźniony cywilizacyjnie. Polska to dla większości z nich „terra incognita” i nie było widać specjalnej szansy dla zmiany tego stanu rzeczy. Paradoksalnie, nawet słynni Polacy, którzy budzili dumę narodową w kraju-t.j. Chopin, Maria Skłodowska-Curie, Kopernik nie wszędzie utożsamiani byli z Polską. Dwoje pierwszych wciąż jest uważanych za Francuzów, a trzeci za Niemca ${ }^{20}$. W procesie negocjacyjnym sytuacji Polski zauważalna była pewna ambiwalencja - Polskę uznano za jedno z najważniejszych nowych państw ze względu na jej wielkość, liczbę ludności, położenie geograficzne i tempo rozwoju gospodarczego. $Z$ drugiej zaś strony często wypominano nam, że „Polska była kandydatem balansującym na granicy wypadnięcia z pierwszej fali rozszerzenia, słabo przygotowanym do integracji (np. w porównaniu z Węgrami i Słowenią), mającym poważne opóźnienia w przyjmowaniu acquis communautaire. (...) Pojawiały się mocno akcentowane sugestie, że postawa Polski szkodzi nie tylko jej samej,

\footnotetext{
${ }^{18}$ L. Kolarska-Bobińska „Odmienność oswajana. Obraz Polski ....”, op.cit.

${ }^{19}$ Wypowiedzi urzędników Komisji w wywiadach dla: Victor Martinez Reyes „Reguły gry, czyli o negocjacjach akcesyjnych i łączeniu się Europy”, Wyd. Naukowe Scholar Warszawa 2000, s. 213- 214.

${ }^{20}$ A. Grzeszak „Poland-gdzie to jest? Przymiarka do marki”, Polityka 25.05.2002.
} 
ale też innym krajom kandydującym". ${ }^{21}$ Po rozpoczęciu wojny w Iraku do narodowych wad dołączyła 'podwójna lojalność, jaką wykazaliśmy wobec rządów państw Europy Zachodniej. Pojawiły się głosy o polskim 'ślepym proamerykanizmie' i o polskim 'ośle trojańskim'. Gdyby o wejściu do Unii decydowały referenda i poparcie społeczeństw państw członkowskich, nasze przystąpienie do Wspólnot byłoby bardzo mało prawdopodobne.

\section{Obraz Polski i Polaków w dawnych krajach Unii w okresie poakcesyjnym- początkowe sukcesy Polski}

Dziś, ponad dekadę od przystąpienia naszego kraju do struktur europejskich należy zadać sobie to samo pytanie - jak jest postrzegana Polska dzisiaj? Czy jej wizerunek uległ znaczącym zmianom, czy uległ poprawie, a jeśli tak to w jakim zakresie?

Otóż na początek należałoby powiedzieć, że sama akcesja Polski i krajów Wyszehradzkich do struktur unijnych automatycznie przekłada się na poprawę wizerunku, gdyż oznacza „formalne uznanie przez inne państwa członkowskie, że Polska spełniła kryteria kopenhaskie, czyli jest państwem zbudowanym na zasadach rządów prawa, poszanowanie praw mniejszości oraz gospodarki rynkowej”. ${ }^{22}$

Mimo że nie jest to powszechnie znane ani polskiej, ani zagranicznej opinii publicznej Polska awansuje w rankingach gospodarczych i w rankingach najsilniejszych marek państw. Według raportu Country Brand Index autorstwa agencji Futurebrand Polska w 2011 roku awansowała o 3 miejsca w rankingu - wtedy na 113 krajów zajmowaliśmy 79 pozycję. Ale już rok później, w sierpniu 2012 r. według agencji Brand Finance, szacującej wartość marek państw na świecie 'marka narodowa Polski odnotowała największy spektakularny wzrost wartości i po raz pierwszy w historii rankingu znalazł się w czołowej dwudziestce najcenniejszych marek świata. ${ }^{23}$ Polska awansowała z 24 pozycji na 20. miejsce i po raz pierwszy wartość marki Polska została wyceniona na 472 mld dolarów. Ze wszystkich badanych krajów i ich marek wartość marki Polska osiągnęła najwyższy skok - aż o 75\%. Według autorów badania Polska osiągnęła te wartości dzięki przewidywanym $3 \% \mathrm{PKB}$, co uważane jest za szczególnie dynamiczne.

Kolejny sukces odniosła Polska również w najnowszym rankingu „Doing Business 2017” Banku Światowego. Na 190 ocenianych krajów odnieśliśmy 24. miejsce - był to skok o jedną pozycję w stosunku do roku 2016. Awans ten zawdzięczamy głównie dzięki reformie prawa podatkowego, restrukturyzacyjnego i upadłościowego, co przyczyniło się do znaczącej poprawy sytuacji przedsiębiorców w naszym kraju. Wyprzedziliśmy większość krajów naszego regionu: Czechy zajęły 27. miejsce, Słowacja miejsce 33., Rumunia 36., Bułgaria 39. oraz Węgry 41. Przed nami uplasowały się tylko państwa bałtyckie- Estonia z 12. miejsca awansowała na 10., Łotwa zajęła 14. i Litwa $21 .^{24}$

\footnotetext{
${ }^{21}$ M. Warchala (red). ,Wizerunek Polski w prasie krajów Unii Europejskiej”, wyd. Instytut Spraw Publicznych, Warszawa 2002.

${ }^{22}$ J. Fomina, J.Frelak „Wizerunek Polski i Polaków w Wielkiej Brytanir”, wyd. ISP 2011, s.11.

${ }^{23}$ K. Niklewicz „Przewodnictwo Polski w Radzie Unii Europejskiej”, 2013, s.261-262.

${ }^{24} \mathrm{http}$ ///www.doingbusiness.org/reports/global-reports/doing-business-2017.
} 


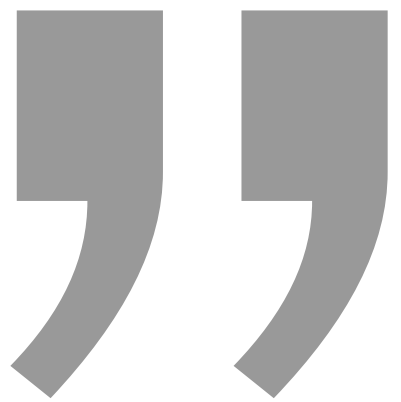

Społeczeństwo polskie jest uważane za jedno z najmłodszych na kontynencie, co w obliczu kryzysu demograficznego u starzejących się społeczeństw Europy Zachodniej i pojawiających się tam problemów z zachwianiem równowagi liczebnej między pokoleniami, niską wydolnością systemów emerytalnych i koniecznością importowania sity roboczej w przyszłości, ukazuje Polskę jako kraj nowych możliwości.

Coraz częściej zaczyna się postrzegać Polskę jako kraj nowych szans, gdzie wzrost gospodarczy osiaga ponad 3\% PKB rocznie. W momencie akcesji do Unii Europejskiej wartość nominalna PKB w Polsce wynosiła 883,7 miliarda złotych, natomiast 10 lat później było to już 1 635,7 miliarda złotych, czyli prawie 2x więcej. Z kolei PKB per capita w 2004 roku wynosił 50,5 \% średniej UE, po 10 latach przekroczył 66,8 \% średniej Unii Europejskiej. Przewiduje się, że jeśli uda się utrzymać się zbliżony poziom wzrostu gospodarczego to w 2025 roku PKB per capita w Polsce osiągnie wartość 70\% średniej państw dawnej „UE- 15”25.

Wartość inwestycji zagranicznych w Polsce wykazuje tendencje rosnące, co dowodzi wzrastającego zaufania u zachodnich przedsiębiorców do naszego kraju. Dzięki dotacjom unijnym rozwijają się również polskie miasta. Społeczeństwo polskie jest uważane za jedno z najmłodszych na kontynencie, co w obliczu kryzysu demograficznego u starzejących się społeczeństw Europy Zachodniej i pojawiających się tam problemów z zachwianiem równowagi liczebnej między pokoleniami, niską wydolnością systemów emerytalnych i koniecznością importowania siły roboczej w przyszłości, ukazuje Polskę jako kraj nowych możliwości.

Również polscy przedsiębiorcy coraz śmielej zaczynają zdobywać rynki zagraniczne. Liderem wśród polskich firm jest tu KGHM Polska Miedź SA; w coraz większej ilości krajów hasło „made in Poland” zaczyna kojarzyć się coraz lepiej. I tak polskie autobusy marki Solaris jeżdżą po drogach Norwegii, Niemiec, Austrii i Włoch. Bydgoska Pesa produkuje pociągi, które jeżdżą nie tylko w Polsce, ale również w Rosji, Czechach, Niemczech i Włoszech. Polskie okna firm Fakro, Drutex i Oknoplast znajdują nabywców na Ukrainie, Węgrzech, w Niemczech, Wielkiej Brytanii, Francji, USA, Austrii, Szwajcarii, także w Australii i na Bliskim Wschodzie. Firma Ursus eksportuje swoje

\footnotetext{
${ }^{25} \mathrm{http} / /$ www.bankier.pl/wiadomosc/PKB-na-osobe-w-Polsce-goni-srednia-UE-Mocny-wzrost-do-2018-roku7255686.html
} 
traktory na rynek afrykański, a Inglot nabywców swoich kosmetyków poza Europą Zachodnią i USA znalazł również na Filipinach, w Indiach, w państwach arabskich i w południowej Afryce. Firma CD Project reklamowała się na Times Square w Nowym Yorku; grę „Wiedźmin” sprzedała w liczbie 16 mln egzemplarzy na całym świecie. Coraz bardziej popularna na świecie staje się firma Audioteka z oryginalnym systemem sprzedaży swoich audiobooków. ${ }^{26}$

Do tego coraz popularniejsze stają się polskie marki premium. Jachty firm Sunreef, Galeon i Delphia w 90\% sprzedają się na eksport na całym świecie. Za produktu o wysokim prestiżu uważa się polskie wódki tj. Belvedere i Chopin. Firma Irena Eris jest obecna w Niemczech i Wlk. Brytanii (jej produkty można kupić w londyńskim Harrodsie); we Francji zaistniała w prestiżowym gronie Comite Colbert. Wysoko punktowane stają się polskie hotele i turystyka SPA. Polscy przedsiębiorcy coraz mocniej zaznaczają swoją obecność również w segmencie marek luksusowych.

Rok temu Polska znalazła się również w gronie 20 najczęściej odwiedzanych państw na świecie. Od 2000 r przyjechało do Polski 220 mln turystów, co w 2015 roku uczyniło Polskę 18 najbardziej popularnym turystycznie państwem na świecie i $11 \mathrm{w}$ Europie. ${ }^{27} 1$ listopada 2015 roku specjaliści z Lonely Travel zaliczyli nasz kraj do grupy 10 krajów na świecie i tylko 2 w Europie, które zostały wyróżnione tytułem „Best in Travel $2016 ” .{ }^{28}$ Miasta polskie na które eksperci z Lonely Travel zwrócili uwagę to: Wrocław jako Europejska Stolica Kultury 2016 r., Kraków jako miejsce Światowych Dni Młodzieży w 2016 r., poza tym: Łódź, Szczecin, Gdańsk; za interesujący region zostały również uznane Mazury i Puszcza Białowieska. Według szacunków POT w 2014 roku do Polski przyjechało $16 \mathrm{mln}$ turystów, co oznaczało $1 \mathrm{mln}$ więcej niż w roku 2012. Najwięcej turystów przyjeżdża do nas z Republiki Federalnej Niemiec, Czech, Ukrainy, Słowacji, ale także Wielkiej Brytanii i Holandii. Obecnie w Polsce wplywy z turystyki sięgają rocznie 5\% PKB.

Również wybór Donalda Tuska na przewodniczącego Rady Unii Europejskiej, a Elżbiety Bieńkowskiej na Europejskiego Komisarza ds. Rynku Wewnętrznego i Usług bez względu na komentarze w kraju początkowo postrzegany był jako sukces Polski. Wśród opinii zagranicznych przeważało podejście, że nie jest to równoznaczne z osiągnięciem przez Polskę statusu równoprawnego z pozostałymi krajami UE-15, ale pozycji międzynarodowej, która wcześniej była dla Polski zupełnie niedostępna.

\section{Polska ponad 10 lat po akcesji do UE - wyniki badań polskiej i międzynarodowej opinii publicznej}

Badania opinii publicznej prowadzone w krajach Zachodniej Europy pokazują jednak, że Polska wciąż postrzegana jest jako jeden z najbiedniejszych krajów Europy. Podobnie pokazywana jest dziś Grecja. Badania „European perception of life in

\footnotetext{
${ }^{26} \mathrm{http}: / /$ www.polandgoglobal.pl

${ }^{27} \mathrm{http} / /$ wyborcza.biz/biznes/1,100896,19329021,polska-w-pierwszej-dwudziestce-najchetniejodwiedzanych-krajow.html

${ }^{28} \mathrm{http}$ ///www.pot.gov.pl/nowosci/l/wiadomosci/wiadomosci-z-pot/nagrody-best-in-travel-2016-rozdanepolska-w-czolowce-swiatowych-destynacji-turystycznych
} 


\section{PUBLIC RELATIONS W INSTYTUCJACH NON-PROFIT}

other countries ${ }^{29}$ przeprowadzone w marcu 2016 roku przez Livewhat, agencję afiliowaną przy Institute of Citizenship Studies (InCite) na Uniwersytecie w Genewie pokazują, że jedynie $25 \%$ respondentów z badanych krajów uważało, że warunki życia w Polsce są dobre. Również większość badanych oceniła, że życie w Polsce (i również Grecji) ,jest mniej szczęśliwe niż jest w rzeczywistości", podczas gdy Polacy posiadają bardziej przychylny obraz swoich sąsiadów. Dla porównania najlepsze oceny u wszystkich badanych zebrała Szwajcaria i Szwecja, wysoko notowane są również Niemcy. Grecja wypadła najgorzej w zestawieniu- w większości badanych krajów tylko $10 \%$ respondentów uważa, że warunki życia w tym kraju są wystarczające. Kraje południa Europy, tj. Hiszpania i Włochy wypadają nieznacznie lepiej niż Polska. Co ciekawe większość obywateli badanych krajów czyli Francji, Niemiec, Włoch, Szwecji, Szwajcarii deklaruje, że życie w kraju sąsiada jest lepsze niż w ich kraju macierzystym (tab.3).

Tab.3. Postrzeganie przez mieszkańców Europy warunków życia w różnych krajach

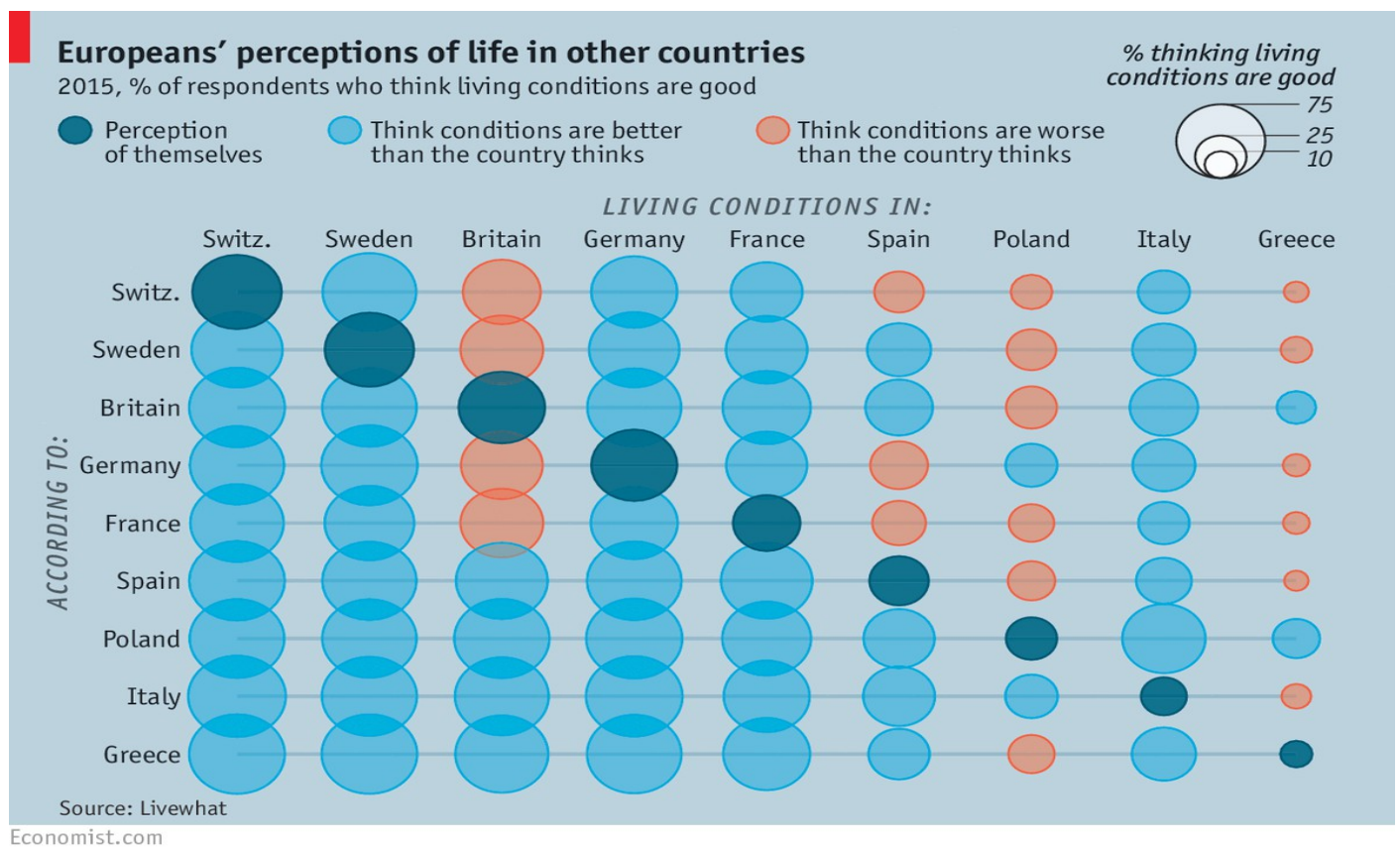

Źródło: Livewhat, Geneva-based survey, The Economist 29.03.2016.

Symptomatyczne jest, że poparcie dla procesu dalszego rozszerzenia UE w krajach dawnej UE-15 utrzymuje się na niskim poziomie. Najnowsze badania Eurobarometru z listopada 2016 r. pokazują, że poparcie dla dalszego rozszerzania Unii w krajach za-

${ }^{29}$ Livewhat, Geneva-based survey, cyt. za: “Green-eyed continent”, The Economist 29.03.2016. 
łożycielskich jest nadal niewielkie. 71\% Austriaków, 68\% Niemców i 65\% obywateli Francji i Luksemburga opowiada się przeciwko temu procesowi. Obywatele UE, którzy wykazują wysoki poziom poparcia dla rozszerzania UE należą najczęściej do grupy krajów niedawno przyjętych, tj.: Litwa (65\% pozytywnych wskazań), Chorwacja (62\%), Rumunia $(61 \%){ }^{30}$ (tab.4).

\section{Tab.4. Poparcie dla dalszego rozszerzenia w krajach Unii Europejskiej}

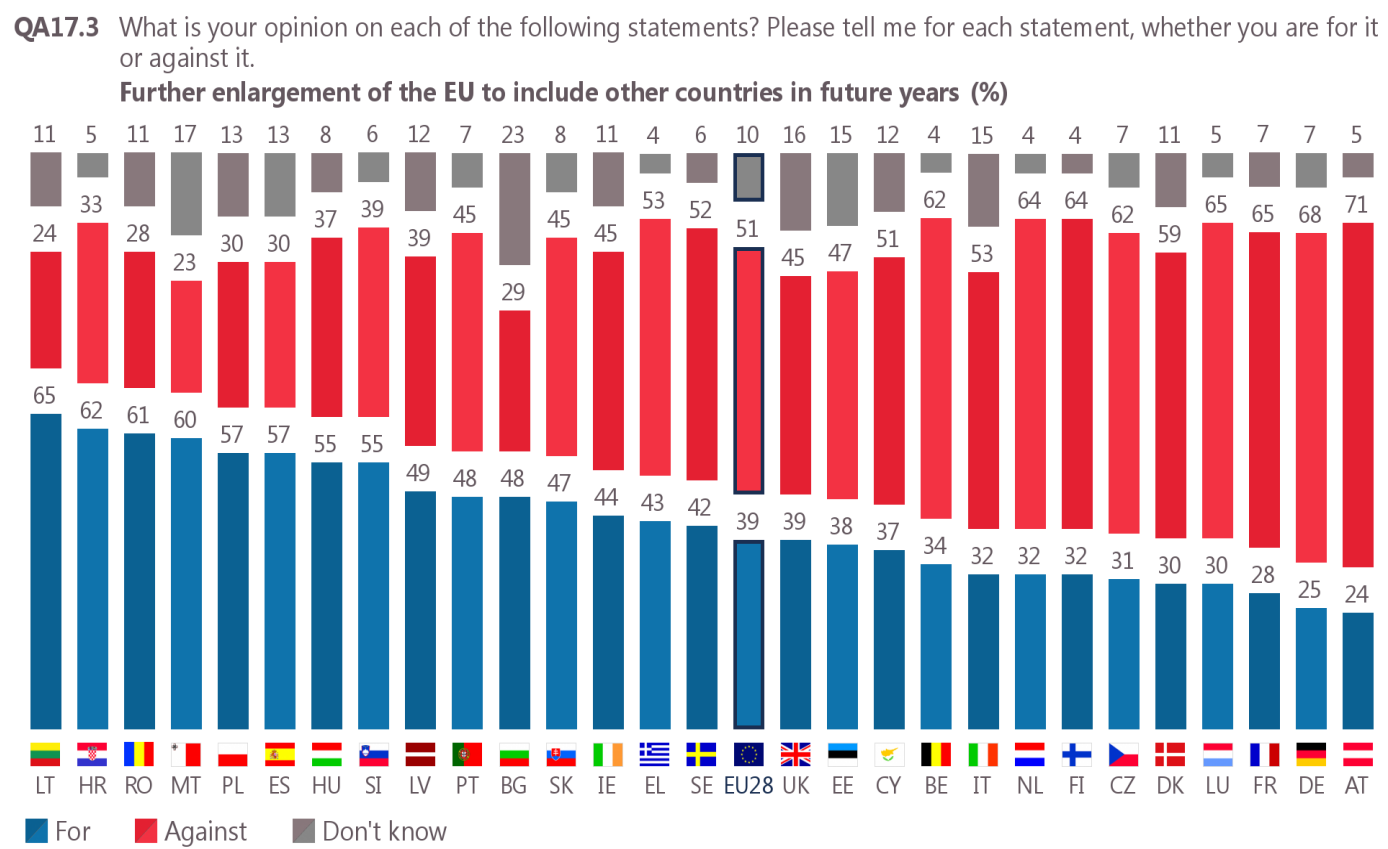

Źródło: Standard Eurobarometr nr 86, listopad 2016.

Badania wizerunkowe, realizowane przez Pew Research Center z kolei dotykają delikatniejszej materii- wzajemnych stereotypów narodowych. ${ }^{31}$ W badaniu PEW z 2013 r. jako naród „najbardziej godny zaufania” uznani zostali Niemcy, co nie przeszkodziło respondentom wytypować ich jako również „najbardziej aroganckich” i „najmniej współczujących” (wskazania większości respondentów). Polacy w tym zestawieniu zostali wskazani jako „najmniej aroganccy” i „najbardziej współczujący” jedynie przez swoich rodaków, natomiast pozostali badani w tych kategoriach nie wymienili Polaków (tab.5).

\footnotetext{
${ }^{30}$ Standard Eurobarometr nr 86, Europeans' opinion of the EU's priorities, listopad 2016: http://ec.europa.eu/COMMFrontOffice/publicopinion/index.cfm/Survey/getSurveyDetail/instruments/S TANDARD/surveyKy/2137, s.22.

${ }^{31}$ https://richardbrenneman.wordpress.com/2013/05/14/chart-of-the-day-how-europeans-see-each-other/
} 
Tab.5. Tworzenie stereotypów w Europie

\begin{tabular}{|c|c|c|c|c|c|c|}
\hline \multirow[b]{2}{*}{ Views in: } & \multicolumn{5}{|c|}{$\begin{array}{c}\text { Who Is Trustworthy, Arrogant and Compassionate } \\
\text { EU nation most likely to be named... }\end{array}$} & \multirow[b]{2}{*}{$\begin{array}{c}\text { Least } \\
\text { Compassionate } \\
\text { Germany }\end{array}$} \\
\hline & $\begin{array}{c}\text { Most } \\
\text { Trustworthy } \\
\text { Germany }\end{array}$ & $\begin{array}{l}\text { Least } \\
\text { Trustworthy } \\
\text { France }\end{array}$ & $\begin{array}{c}\text { Most } \\
\text { Arrogant } \\
\text { France }\end{array}$ & $\begin{array}{c}\text { Least } \\
\text { Arrogant } \\
\text { Britain }\end{array}$ & $\begin{array}{c}\text { Most } \\
\text { Compassionate } \\
\text { Britain }\end{array}$ & \\
\hline France & Germany & Greece & France & France & France & Britain \\
\hline Germany & Germany & Greece/Italy & France & Germany & Germany & Britain \\
\hline Italy & Germany & Italy & Germany & Spain & Italy & Germany \\
\hline Spain & Germany & Italy & Germany & Spain & Spain & Germany \\
\hline Greece & Greece & Germany & Germany & Greece & Greece & Germany \\
\hline Poland & Germany & Germany & Germany & Poland & Poland & Germany \\
\hline Czech Rep. & Germany & Greece & Germany & Slovakia & Czech Rep. & Germany \\
\hline
\end{tabular}

Źródło: PEW, maj 2013.

Niemcy wskazywani są jako „najciężej pracujący” i „najmniej skorumpowani” we wszystkich zestawieniach. Najgorszą opinią cieszą się Grecy. W niechlubnym rankingu narodów „najmniej pracowitych” i „najbardziej skorumpowanych” (tab.6) zwyciężają najczęściej narody południa Europy, tj. Włosi, Hiszpanie i Grecy. ${ }^{32}$ Żaden badany naród nie wymienił w tych wskazaniach Polaków, co może napawać optymizmem, gdyż wysoki poziom korupcji był jedną z negatywnych cech, jaką zarzucano nam w momencie akcesji do UE.

Tab.6. Tworzenie stereotypów w Europie

\begin{tabular}{|c|c|c|c|c|}
\hline \multicolumn{5}{|c|}{ Stereotyping in Europe } \\
\hline \multicolumn{5}{|c|}{$\begin{array}{c}\text { Who Works Hardest, Who's Corrupt } \\
\text { EU nation most offered as top choice as... }\end{array}$} \\
\hline Views in: & $\begin{array}{c}\text { Most } \\
\text { Hardworking }\end{array}$ & $\begin{array}{c}\text { Least } \\
\text { Hardworking }\end{array}$ & $\begin{array}{c}\text { Most } \\
\text { Corrupt }\end{array}$ & $\begin{array}{c}\text { Least } \\
\text { Corrupt }\end{array}$ \\
\hline Britain & Germany & Greece & Ita & Germany \\
\hline France & Germany & Italy & Italy & Germany \\
\hline Germany & Germany & Greece & Italy & Germany \\
\hline Spain & Germany & Greece & Spain/Italy & Germany \\
\hline Italy & Germany & Romania & Italy & Germany \\
\hline Greece & Greece & Italy & Greece & Germany \\
\hline Poland & Germany & Greece & Poland & Germany \\
\hline Czech Rep. & Germany & Greece & Czech Rep. & Germany \\
\hline
\end{tabular}

Źródło: Pew 2012, The Economist 4.06.2012

${ }^{32}$ A. Santoso „Greek Think They're the Hardest Working People in Europe”, The Economist 4.06.2012. 

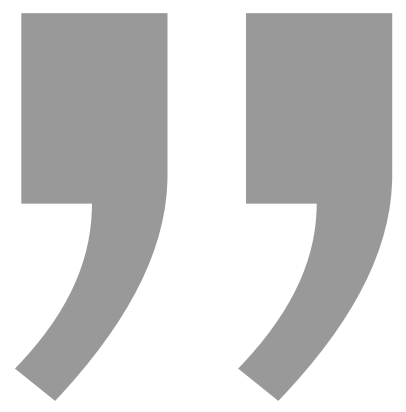

Trudno oprzeć się wrażeniu, że obraz Polski wyłaniający się z polskich badań opinii i opracowań naukowych publikowanych w Polsce jest lepszy niż ten wyłaniający się z raportów, czy statystyk zachodnich. U nas akcentuje się dynamikę pozytywnych zmian, zmniejszający się dystans do krajów rozwiniętych, proǵres jakiego udało nam się dokonać przez ostatni czas; w opracowaniach i tekstach publikowanych w państwach zachodnich akcentowane są przede wszystkim niechęć do dalszego rozszerzania u społeczeństw zachodnich, zagrożenia powstałe na rynku pracy związane z falami migracji czy negatywny obraz rozszerzania wschodniegó.

Brak konkretnych wskazań w badaniach PEW dla Polski wynika być może z tego, że Polska w tamtym czasie - jak podkreślali eksperci - jeśli chodzi wizerunek ogólny była „krajem bez twarzy” "33, tzn. nie miała wyraźnego wizerunku na arenie międzynarodowej. Z badań OBOP dla MSZ wynikało, że wizerunek Polski i Polaków na zachodzie był niespójny- z jednej strony uważano, że wizerunek naszego kraju jest nijaki, $z$ drugiej podkreślano, że „wizerunek polskich obywateli jest w ogromnej większości przypadków lepszy i bardziej wyrazisty niż wizerunek całego kraju”. ${ }^{34}$

Niestety, nie oznacza to, że we wszystkich krajach wizerunek Polaków jest taki sam i tak z badań TNS OBOP z 2013 r. wynika, że narody, które wykazują najwięcej symptomów sympatii w kierunku naszego kraju to Portugalczycy, Hiszpanie, Francuzi oraz Ukraińcy. Z kolei najmniej zwolenników mamy w Holandii, Austrii i Niemczech, co jest bardzo charakterystyczne, gdyż Holandia i Niemcy, jak również Wielka Brytania są to najbardziej popularne destynacje, do jakich migrują Polacy po 2004 r. ${ }^{35}$ Dość oczywista może się także wy-

\footnotetext{
${ }^{33}$ W. Smoczyński „Polska - kraj bez twarzy”, Polityka 30.06. 2009, Marketingowa Strategia Polski w sektorze turystyki na lata 2008-2015; Analiza wyników badań wizerunku Polski i postrzegania polskiej marki na świecie 2008.

${ }^{34}$ Badanie opinii „,Określenie wizerunku, który Polska powinna promować z granicą”, Laboratorium Badan Społecznych dla MSZ, Warszawa listopad 2013, s.18.

${ }^{35}$ Według danych GUS pod koniec roku 2015 poza granicami Polski przebywało $2 \mathrm{mln} 397$ tys. obywateli
} 
dawać konstatacja, że zachodni Europejczycy postrzegają nas jako Wschód Europy, a dla mieszkańców Wschodu Europy-jak np. dla Ukraińców „Polska to już Zachód”. ${ }^{6}$

Warto przyjrzeć się wynikom badań nad obrazem Polski w wybranych krajach UE. Cykliczne badania nad wzajemnymi wizerunkami Polaków i Niemców, tzw. „Barometr Polska - Niemcy” prowadzi Instytut Spraw Publicznych. Badania ISP pokazują, że w Niemczech w postrzeganiu Polski zarysowuje się pewna dwoistość ${ }^{37} \mathrm{Z}$ jednej strony Polska kojarzona była jeszcze niedawno z trudną sytuacją gospodarczą, która wypycha swoich obywateli do niskokwalifikowanych prac sezonowych; słynne określenie „Polnische wirtschaft” było symbolem skrajnej niegospodarności i bałaganu. W niektórych kręgach społecznych, zwłaszcza przy terenach przygranicznych obecny był żywy stereotyp Polaka jako złodzieja samochodó $w^{38}$ i obraz Polski jako kraju o wysokiej przestępczości. Z drugiej strony - Polska coraz częściej jest postrzegana przez pryzmat dynamicznych zmian gospodarczych, licznych inwestycji infrastrukturalnych i wzajemnych kontaktów biznesowych. W 2016 r. wartość polsko - niemieckiej wymiany gospodarczej przekroczyła 100 mld euro (wzrost o 22 mld od roku 2013) ${ }^{39}$, co sprawia, Polska staje się jednym z ważniejszych partnerów handlowych dla Niemiec. Nie pozostaje to bez wpływu na wzajemne postrzeganie się obu narodów. I tak, pomimo że Niemcy deklarowali, że nie uważają, że Polacy jako ludzie są do nich podobni - w ich opinii daleko bliżej było nam do Rosjan ${ }^{40}$, tak w badaniach późniejszych twierdzili, że byliby w stanie zaakceptować Polaka jako kolegę z pracy (79\% pozytywnych wskazań), również jako obywatela swojego kraju (62\% odpowiedzi na tak), a także jako zięcia (49\%). ${ }^{41}$ Wynika z tego, że poziom społecznej akceptacji Niemców dla Polaków wykazuje tendencje rosnące.

W Belgii również panuje dwoistość w postrzeganiu naszego kraju i obywateli z jednej strony dominuje stereotypowy obraz Polaka: słabo wykształconego, pracującego na czarno emigranta w niskokwalifikowanej pracy, nierzadko nadużywającego alkoholu. Polska postrzegana jest jako kraj wolno rozwijający się, o zimnym klimacie; kojarzący się z trudną historią (II wojna światowa, lata komunizmu). Z drugiej strony - w opiniach międzynarodowej populacji urzędników obraz Polski jest zgoła inny - cechy, jakie się

\footnotetext{
naszego kraju, szacowanych łącznie jako liczba migrantów tymczasowych i osób, które na stale osiedliły się poza Polską. I tak w Wielkiej Brytanii w 2015 r. przebywało 720 tys. Polaków (według nieoficjalnych danych ponad 100000), w Niemczech 655 tys., w Holandii 112 tys., w Irlandii 111 tys. Liczba polskich emigrantów wzrosła o 82 tys. w stosunku do poprzedniego roku.

${ }^{36}$ Badanie opinii „Określenie wizerunku...”, Laboratorium Badan Społecznych dla MSZ, Warszawa, listopad 2013, s. 20.

37 „Barometr Polska-Niemcy”, Instytut Spraw Publicznych, jesień 2013.

${ }^{38}$ Za czasów komunizmu zostały ukute nawet powiedzenia: „Fast gestohlen, schon in Polen” i „Fahren sie nach Polen, ihre Auto ist schon da”, czyli: „Dopiero co ukradzione, jest już w Polsce”, „Proszę jechać do Polski, pana auto już tam jest".

${ }^{39}$ Por.: https://www.obserwatorfinansowy.pl/tematyka/makroekonomia/wymiana-handlowa-miedzypolska-a-niemcami-na-rekordowym-poziomie/

${ }^{40}$ Szerzej por.: „Barometr Polska-Niemcy”, Instytut Spraw Publicznych, jesień 2013.

${ }^{41}$ Szerzej por.: „Barometr Polska- Niemcy”, op.cit.
} 
przypisuje Polakom to: „ambicja, odwaga, przebojowość, młodość, dynamizm” ${ }^{42}$, akcentowany jest rzeczywisty potencjał i dynamika zmian naszego kraju.

Ciekawie prezentuje się wizerunek Polaków w Wielkiej Brytanii. W ciągu ostatnich 10 lat nastąpiła pozytywna zmiana wizerunkowa w postrzeganiu Polski. Społeczeństwo brytyjskie w większości ma świadomość, że Polska jest krajem demokratycznym, w którym dominuje demokracja parlamentarna i gospodarka rynkowa. 60\% badanych twierdzi, że miało kontakty z Polską, czy Polakami i uważa ich za godnych zaufania - zaakceptowaliby ich w roli turysty, sąsiada, czy członka rodziny. Pomimo, że jedynie 6\% Brytyjczyków przebywało w Polsce z wizytą, ponad połowa Brytyjczyków uważa, że Polacy są do nich podobni. Wizerunek Polaków w Wielkiej Brytanii nie jest jednak wolny od obciążeń - Brytyjczycy wciąż postrzegają Polskę jako kraj biedny, zacofany, dotknięty korupcją i biurokracją; co ciekawe jako mniejszy i mniej zaludniony niż w rzeczywistości. ${ }^{43}$ Uważają, że polska emigracja przyczyniła się do zbytniego obciążenia brytyjskiego systemu opieki społecznej i przyczyniła się do wzrostu bezrobocia w niektórych grupach zawodowych, co może powodować napięcia społeczne. Pomimo jednak, że wciąż trwają negocjacje nad warunkami wystąpienia Wielkiej Brytanii z UE (napięcia związane z Brexitem), jak również nad ograniczeniem profitów brytyjskiego systemu socjalnego dla imigrantów z UE można powiedzieć, że Polacy cieszą się w UK pewną sympatią. Pracują tam coraz częściej w wyuczonych zawodach jako lekarze, pielęgniarki, inżynierowie, czy pomocnicy biurowi; nie tylko pracownicy fizyczni. Ich praca, bez względu na to jak kwalifikowana cieszy się wśród brytyjskich pracodawców uznaniem. „You are Britan’s favourite migrants”- miał powiedzieć do Polaków brytyjski poseł konserwatywny Greg Hands. ${ }^{44}$ Podobne opinie można znaleźć wśród Polaków mieszkających w Wielkiej Brytanii. Dominika Swieżewska pisze:

\begin{abstract}
”Nasza pracowitość i wykształcenie oraz chęć integracji powoduje, że wizerunek Polaka staje się coraz bardziej pozytywny. Świadczy o tym choćby zapotrzebowanie na polskich fachowców w polskiej gospodarce. Powstają również dokumenty i instytucje mające ułatwić Polakom integrację i życie na Wyspach. Banki udzielają kredytów, Polki rodzą dzieci, Polacy inwestują w nieruchomości, kursy dokształcające. Badania wskazują, że Polacy wciąż czują się w Wielkiej Brytanii raczej jako goście niż równoprawni mieszkańcy. Wszystko jednak przemawia za tym, że o ile wciąż będziemy pracować nad naszym pozytywnym wizerunkiem, o tyle z czasem poczujemy się na emigracji bardziej jak u siebie bardziej jak w domu". ${ }^{45}$
\end{abstract}

\footnotetext{
${ }^{42}$ Badanie opinii „Określenie wizerunku...”, Laboratorium Badań Społecznych dla MSZ, Warszawa, listopad 2013, s.18.

${ }^{43}$ Badanie opinii „Określenie wizerunku...”, Laboratorium Badań Społecznych dla MSZ, Warszawa, listopad 2013, s.18.

${ }^{44}$ M.P. Garapich „Migracje, społeczeństwo obywatelskie i władza. Uwarunkowania stowarzyszeniowości etnicznej i rozwoju społeczeństwa obywatelskiego wśród polskich emigrantów w Wielkiej Brytanii, w: Fomina, Frelak, art. cyt. s. 14 .

${ }^{45}$ Dominika Swieżewska „Jak postrzegają nas Brytyjczycy, czyli wizerunek Polaka na Wyspach”w: http://polemi.co.uk/lajt/artykuly/wizerunek-polakow-w-wielkiej-brytanii-5511, www.kobietawuk.info.
} 
Trudno nie zauważyć, że właśnie migranci staja się wizytówką naszego kraju za granicą i od nich również zależały będą zmiany w postrzeganiu Polski. Warto jeszcze raz podkreślić, że obywatele naszego kraju cieszą się większą sympatią i lepszym wizerunkiem niż samo państwo polskie, które lepiej i bardziej prawdziwe prezentuje się wśród elit europejskich niż wśród zwykłych ludzi.

Trudno oprzeć się wrażeniu, że obraz Polski wyłaniający się z polskich badań opinii i opracowań naukowych publikowanych w Polsce jest lepszy niż ten wyłaniający się z raportów, czy statystyk zachodnich. U nas akcentuje się dynamikę pozytywnych zmian, zmniejszający się dystans do krajów rozwiniętych, progres jakiego udało nam się dokonać przez ostatni czas ${ }^{46}$; w opracowaniach i tekstach publikowanych w państwach zachodnich akcentowane są przede wszystkim niechęć do dalszego rozszerzania u społeczeństw zachodnich ${ }^{47}$, zagrożenia powstałe na rynku pracy związane z falami migracji czy negatywny obraz rozszerzania wschodniego. ${ }^{48}$ Zauważane są również deficyty i mankamenty krajów należących do New Members States. ${ }^{49}$ Adam Balzer z demosEuropa relacje Polski i UE trafnie określił jako „miłość platoniczną". ${ }^{50}$

\section{„Polska jako nowy ból głowy Europy”. Polska i Polacy w wybranych materiałach z prasy zachodniej}

Na szczególną uwagę zasługuje czas po wyborach parlamentarnych z 25 X 2015 r., kiedy przez media zachodnie przetoczyła się lawina tekstów przedstawiających Polskę w negatywnym świetle. Wygraną Prawa i Sprawiedliwości korespondenci prasy zagranicznej skomentowali jako wybór „Polski zaściankowej, ksenofobicznej, wręcz radykalnej”. Oto niektóre fragmenty ich publicystyki: „Polska obrała niebezpieczny kurs w kierunku autorytaryzmu" 51, "Polska zmierza ku autorytaryzmowi w stylu Orbána"52, Polska przywraca „sowiecki model cenzury, którym (...) świat powinien się poważnie zaniepokoić". ${ }^{53} \mathrm{Na}$ uwagę zasługują także następujące teksty: "Retoryka drutu kolczaste-

\footnotetext{
${ }^{46}$ „Barometr Polska-Niemcy”, Instytut Spraw Publicznych, jesień 2013, Badanie opinii „Określenie wizerunku...”, Laboratorium Badań Społecznych dla MSZ, Warszawa, listopad 2013.

${ }^{47}$ Np. Standard Eurobarometr nr 86, listopad 2016.

${ }^{48}$ U. Sedelmeier „Europe after the Eastern Enlargement of the European Union: 2004-2014”, Heinrich Boell Stiftung, w: http://aiv-advies.nl/download/1b2da592-0f83-4791-b83f-fe822471ff84.pdf, I. Bond " $E U$

Enlargement', Center for European Reform, www.cer.org.uk.

49 "The EU Capacity for Futher Enlargeement" nr 71, Advisory Council on International Affairs $2010 \mathrm{w}$ : http://aiv-advies.nl/download/1b2da592-0f83-4791-b83f-fe822471ff84.pdfs, I. Bond "EU Enlargement", Center for European Reform, www.cer.org.uk.;

http://www.cer.eu/sites/default/files/publications/attachments/pdf/2014/bal_comp_ib_eu_enlargement july2014-9463.pdf

${ }^{50}$ A. Balzer ,Just A Platonic Love?- Poland and the EU Enlargement" w: "Poland and the Czech Republic: Advocates of the EU Enlargement?' wyd. Demos EUROPA Center for European Strategy Warszawa 2010.

${ }^{51}$ J. Diehl “Poland's disturbing tilt to the right", The Washington Post 29.11.2015.

${ }^{52}$ F. Zakaria, CNN o Polsce, CNN, 6.12.2015.

${ }^{53}$ F. Zakaria, op.cit.
} 
go” ${ }^{44}$, „Polska jako nowy ból głowy Europy” ${ }^{55}$, „Polska - nowy rząd już po dwóch tygodniach denerwuje Europę". ${ }^{56}$ Ze względu na duży komponent emocjonalny zawarty w tych tekstach, należy im się osobna analiza.

I tak w artykule „Polska jako nowy ból głowy Europy”- „Europe’s new headache” możemy przeczytać, że:

„Kiedy PIS było ostatni raz u władzy, jego rządy cechowały nieodpowiedzialne posunięcia i nacjonalistyczna paranoja. Wydaje się, że mimo upływu czasu nic się nie zmieniło. Podczas swoich poprzednich rządów w latach 20052007, PIS wdawało się w bójki z Niemcami i stworzyło atmosferę histerycznej nieprzewidywalności. (...) Polska była okrętem flagowym ekspansji na wschód, dowodem, że demokrację i rządy prawa można eksportować. Jeśli PIS chce skończyć te erę, jest na najlepszej drodze. (....) Ten zwrot ku populizmowi zaszkodzi Polsce. Ale większym zmartwieniem jest to, że może tez sparaliżować Unię w najważniejszych dla niej problemach, a zwłaszcza w sprawie kryzysu uchodźczego" ${ }^{\circ 7}$.

Również niemieckie media wykazują zaskakującą zbieżność narracji. „Suddeutsche Zeitung” pisze:

„Nowy polski rząd, kierowany przez swojego spiritus rector Jarosława Kaczyńskiego, natychmiast rozpoczął przebudowę Polski w państwo, w którym władza przestała być podzielona i kontrolowana, lecz została całkowicie skupiona w rękach Kaczyńskiego i jego nacjonalistycznej partii PIS.”58

„Die Welt” ostrzega:

„W Polsce grozi ni mniej nie więcej jak dyktatura, tym razem nie komunistyczna, lecz narodowo-konserwatywna. To bardzo źle dla Polski, a w dodatku jest to naigrywaniem się z odwagi i ofiarności ludzi, którzy walczyli i zginęli w walce o Polską demokrację". ${ }^{59}$

\footnotetext{
${ }^{54}$ H. Foy „Barbed rhetoric”, Financial Times 27.11.2015.

55 „Europe's new headache. The new government in Poland has made an awful start”, The Economist 5.12. 2015.

56 „The return of the awkward squad. Two weeks in, Poland's new government is making Europe nervous”, The Economist 5.12.2015.

57 „Europe's new headache. The new government in Poland has made an awful start”, The Economist 5.12.2015, za http://wiadomosci.gazeta.pl/wiadomosci/1,114871,19291093,jak-the-economist-widzi-dzispolske-6-naprawde-gorzkich-cytatow.html

${ }^{58}$ S.Ulrich “Kaczyński zerstört den polnischen Rechtsstaat”, Sueddeutsche Zeitung 23.12.2015, thum. za: http://www.pap.pl/aktualnosci/news,449879,niemieckie-media-o-polsce-polskie-wladze-przekroczylyrubikon.html

${ }^{59}$ A.Dietrich “Auf dem Weg in die nationalkonservative Diktatur”, Die Welt 23.12.2015, za: http://www.pap.pl/aktualnosci/news,449879,niemieckie-media-o-polsce-polskie-wladze-przekroczylyrubikon.html
} 


\section{PUBLIC RELATIONS W INSTYTUCJACH NON-PROFIT}

„Frankfurter Allgemeine Zeitung” podsumowuje:

„Rząd PIS robi wszystko, by nie być postrzegany jako siła kształtująca politykę, lecz jako problem". ${ }^{60}$

Na szczególną uwagę zasługują materiały Fareeda Zakarii z CNN:

„Wydarzenia w Polsce przybrały bardzo brzydki obrót. Odkąd władzę w Polsce przejęła prawicowa partia Prawo i Sprawiedliwość ruszyła do wielkiego, błyskawicznego przejmowania władzy, które doprowadziło do porównań do zamachu stanu. W wątpliwym prawnie ruchu nowy parlament unieważnił wybór pięciu sędziów Trybunału Konstytucyjnego, by zrobić miejsce dla tych, którzy byliby po myśli partii.(...) To wszystko zaskakujące, ponieważ w ostatnich latach Polska była przykładem stabilności w Europie. W ciągu ostatniej dekady polskie PKB wzrosło o połowę, do kraju ściągnęły wielkie korporacje jak IKEA, Volswagen, czy Amazon. Pomimo tych sukcesów Polacy obrali „nowy kurs” i odsunęli od władzy rządzącą osiem lat Platformę Obywatelską, która wypaliła się przez skandale i złą politykę. (...) Polsce grozi 'sowiecki model cenzury', gdyż cały czas blokowane są wolne media". ${ }^{61}$

„New York Times” podsumowuje:

„Polska jest na drodze do politycznej równi pochyłej, z jakiej stacza się w objęcia brunatnej dyktatury”. ${ }^{62}$

\section{I znowu Fareed Zakaria w CNN:}

„W razie zwycięstwa kandydata republikanów Donalda Trumpa Ameryka mogłaby pójść śladem Polski i Rosji, gdzie doszło do złamania demokracji. Demokracja jest krucha- spójrzcie na Polskę, Rosję i Turcję". ${ }^{63}$

Zwraca uwagę również duża szczegółowość tych tekstów. Wiele z nich na bieżąco przedstawia polityczne dyskusje w naszym kraju, sprawia wrażenie, jakby autorzy doskonale orientowali się w sekwencji wydarzeń politycznych w Polsce.

„The Economist” najczęściej publikuje teksty nie podpisane nazwiskiem autora. Jeśli chodzi o orientację w wewnętrznych sprawach naszego kraju tygodnik ten w niczym nie ustępuje największym polskim mediom. I tak w tekście „The return of the awkward squad” („Powrót kłopotliwej drużyny”) czytamy:

\footnotetext{
${ }^{60}$ R.Veser “Polen und Deutschland: ziemlich beste Freunde”, Frankfurter Allgemeine Zeitung 16.06.2016.

${ }^{61}$ F.Zakaria, CNN o Polsce, CNN, 6.12.2015, za: http://wyborcza.pl/1,75399,19304320,cnn-o-polscewydarzenia-przybraly-bardzo-zly-obrot.html.

62 "Poland's Tragic Turn", New York Times 21.12. 2016.

${ }^{63}$ F. Zakaria „Global Public Square”, CNN o Polsce, CNN 6.12.2016, za: https://oko.press/demokracjakrucha-spojrzcie-polske-rosje-turcje-ekspert-cnn-zniecheca-trumpa/
} 
„Na czym się będzie opierać nowa polityka socjalna nie jest jasne. Zmiany, w szczególności zmiany emerytur są bardzo kosztowne. Proponowane opodatkowanie banków i supermarketów pokrywa jedynie w części te koszty. Deficyt budżetowy może osiągnąc 4 \% w przyszłym roku. W sytuacji, kiedy w Polsce mamy starzejącą się populację, a wielu młodych ludzi decyduje się na emigrację do UE, obniżenie wieku emerytalnego wydaje się być zgubne. (...) Wielu europejskich dyplomatów prywatnie jest bardzo zmartwionych". ${ }^{64}$

W „Courting disaster” („Sądowej katastrofie”) możemy przeczytać:

„Ojciec Rydzyk również jest rozczarowany nowym rządem. Po sporze o dostęp do Prezydenta zagroził PIS wstrzymaniem współpracy, mówiąc, że oczekiwał, że jego media będą traktowane w szczególny sposób. Jeszcze się okaże kogo Kaczynski i jego partia obawiają się bardziej: Unii Europejskiej czy Radia Maryja". ${ }^{65}$

A w: „Illiberalism lives” (,Nieliberalizm żyje”) stoi:

„W trakcie wysiłków pani premier Szydlo, aby pozbawić stanowiska pana Tuska, francuski ustępujący prezydent Francois Hollande powiedział ostro: może Polska ma zasady, ale UE trzyma fundusze strukturalne. W tych dniach często słyszy się takie groźby w Brukseli i Berlinie, głównie po fakcie odmowy przez Polskę i Węgry przyjęcia uchodźców. Nowe rozmowy o budżecie UE zaczynają się w przyszłym roku". ${ }^{66}$

Zagranicznym korespondentom wtórują publicyści i eksperci z Polski. Piotr Buras w artykule „Driving Poland apart” z „The New York Times” (,Polska dzielona, rozbijana na pół”) stwierdza że:

„Nie to jest najgorsze, że Polska jednoczy się pod nacjonalistyczną prawicą. Najgorsze jest to, że Polska rozszczepia się pomiędzy tradycjonalizmem, a liberalizmem". ${ }^{67}$

Zaś prof. Jadwiga Staniszkis w „Die Welt” donosi, że Jarosław Kaczyński: „nie ma żadnej empatii w stosunku do swojego narodu”. ${ }^{68}$

Dla uważnego obserwatora codziennej sceny politycznej powyższe tezy nie będą niczym nowym. Duża część omawianych artykułów odbiła się echem w prasie polskiej; były

\footnotetext{
${ }^{64}$ „The return of the awkward squad”, The Economist 5.12.2015.

65 "Courting disaster", The Economist 2.01.2016.

66 "Illiberalism lives", The Economist 29.04.2017.

${ }^{67}$ P.Buras "Driving Poland apart”, The New York Times 23.12.2015.

68 “Kaczynski hat keine Empathie für sein Volk"- rozmowa z prof. Jadwigą Staniszkis, Die Welt 19.01.2016.
} 


\section{PUBLIC RELATIONS W INSTYTUCJACH NON-PROFIT}

one w niej szeroko komentowane. Pewnym zaskoczeniem może być jedynie fakt, że zaczyna się sugerować, iż „problemy z demokracją” nie są domeną Polski jedynie pod rządami PIS, że właściwie to Polska „nigdy wcześniej nie była prawdziwie demokratyczna”. Odmawia się demokratycznej legitymizacji całemu narodowi. W artykule z "Foreign Policy" ze stycznia 2017 roku „Poland was never democratic as it looked” ("Polska nigdy nie była tak demokratyczna, na jaka wyglądała”) Sean Hanley i James Dawson sugerują, że:

„Transformacja ustrojowa w Polsce i w innych krajach regionu nie była bardzo udana, a budowa demokracji zatrzymała się w połowie drogi. (...) Unia Europejska postawiła na niewłaściwy model demokratyzacji państw postkomunistycznych. Polityka Brukseli zawiodła, ponieważ przyjęto założenie, że demokratyzacja państwowych instytucji doprowadzi do przyjęcia demokratycznych wartości w społeczeństwie. (...) Fasadowa demokracja to wina wszystkich kolejnych rządów po 1989 roku i rok to za krótko, by zmienić cały system instytucji państwowych i wartości wyzwane przez społeczeństwo...”. ${ }^{9}$

Dla polskiego inteligenta również zaskakująca będzie dychotomia ukazująca "altruistyczny zachód” kontra „ksenofobiczny wschód”. W tekście „Barbed rhetoric” („Retoryka drutu kolczastego") Henry Foy i Neil Buckley piszą:

„Po dołączeniu do Unii Europejskiej ponad dekadę temu kraje Europy Wschodniej przyjęły agendę UE, ale wzrastające obecnie nacjonalizm i antyimigrancki sentyment zatrważają ducha unijnej jedności. (....) Teraz debata kształtuje się pomiędzy altruistycznym zachodem, a ksenofobicznym wschodem. Nasze największe niebezpieczeństwo to wpaść w tę pułapkę ". ${ }^{70}$

Pejoratywnie ukazywana jest cała grupa wyszehradzka jako ta, którą cechuje „brak europejskiej solidarności”.

Sprzeciw PIS przy wyborze Donalda Tuska na kolejną kadencję przewodniczącego Rady Europejskiej (pierwszy raz państwo należące do UE nie poparło swojego kandydata) został skomentowany ironicznie. Henry Foy komentuje na Twiterze:

“Tusk wybrany ponownie na Europrezydenta, polski rząd wściekły (...)

Dopiero świta wielu europejskim dyplomatom jak bardzo Tusk jest znienawidzony przez @pisorgpl \& Kaczynskiego (...) Polska premier Szydło mówi, że Polska będzie blokować konkluzje szczytu UE w tej sprawie, ale dodaje, że Polska jest szczęśliwa biorąc unijne pieniądze". ${ }^{71}$

Warto tu zadać sobie pytanie, czy przez ostatnie półtora roku można było znaleźć jakiekolwiek komentarze nt. Polski i Polaków mające wydźwięk pozytywny? Czy pojawi-

\footnotetext{
${ }^{69}$ S. Hanley, J. Dawson, „Poland was never democratic as it looked”, Foreign Policy 3.01.2017.

${ }^{70}$ H. Foy „Barber rhetoric” Financial Times, 27.11.2015.

${ }^{71}$ H. Foy https://twitter.com/henryjfoy?lang=pl 8.03.2017.
} 
ły się teksty (np. w mediach o profilu konserwatywnym), które chwaliły dokonania nowego rządu? Nie było ich wiele, jednak i takie się zdarzały.

Bank Światowy opublikował raport, w którym docenił Polskę za wprowadzenie programu 500+ dzięki któremu udało się zredukować skalę ubóstwa w Polsce o 3 punkty procentowe, czyli zmniejszyć z poziomu 8,9\% do 5,9\%. ${ }^{72}$

Globalny strateg Morgan Stanley Investment Management Ruchir Sharma w lipcu 2017 r. na łamach amerykańskiego dziennika „New York Timesa” prognozował ekonomiczny awans Polski. W tekście „Polska nową ekonomiczną potęgą” sugerował, że:

„Spośród ponad 190 krajów, które są monitorowane przez Międzynarodowy Fundusz Walutowy, mniej niż 40 jest zaliczanych do gospodarek rozwiniętych. Reszta to gospodarki rozwijające się i wiele z nich pozostaje takimi od zawsze. Ostatnim dużym krajem z tej grupy, który przeszedł do grupy krajów rozwiniętych, była Korea Południowa, 20 lat temu. Następnym dużym narodem, który dołączy do klubu państw rozwiniętych, będzie zapewne Polska. (...) Granicą, która oddziela państwa rozwijające się od rozwiniętych, jest PKB per capita na poziomie 15 tys. dolarów. Obecnie w Polsce wynosi on 13 tys., jednak wymagany do awansu poziom zapewne zostanie przekroczony jeszcze w tej dekadzie (...)" ${ }^{73}$

Nie zapomniał o niepokojach rządów zachodnich państw i komentatorów zachodniej prasy, którzy po wygranych przez Prawo i Sprawiedliwość wyborach obawiali się wzrostu populizmu:

„chodziło o ryzyko, że nowy rząd będzie 'mieszał się’ do spraw sektora prywatnego oraz o koszty 'populistycznych’ obietnic. Tyle że obawy się nie spełniły”74.

Dziś wiemy, że jego prognozy się sprawdziły. Pod koniec września 2017 r. po raz pierwszy w swojej historii Polska została uznana za kraj należący nie do grupy krajów rozwijających się (,emerging markets”), a rozwiniętych („developed markets”). Agencja indeksowa FTSE Russell uznała, że jesteśmy pierwszym środkowoeuropejskim państwem w gronie 25 najlepiej rozwiniętych krajów i od września 2018 r. będziemy znajdować się w gronie państw takich, jak np. m.in. Niemcy, Japonia i USA. ${ }^{75}$

\footnotetext{
${ }^{72}$ Karolina Goraus, Gabriela Inchauste "The Distributional Impact of Taxes and Transfers in Poland", Raport Banku Światowego, sierpień 2016, całość w:

https://openknowledge.worldbank.org/bitstream/handle/10986/24868/WPS7787.pdf?

sequence $=4 \&$ isAllowed $=\mathrm{y}$.

${ }^{73} \mathrm{http}$ :// w gospodarce.pl/informacje/38233-new-york-times-polska-nowa-ekonomiczna-potega, także: https://www.nytimes.com/2017/07/05/opinion/poland-economy-trump-russia.html

${ }^{74}$ Op.cit.

${ }^{75}$ https://www.money.pl/gielda/wiadomosci/artykul/ftse-russell-polska-rynekrozwiniety,122,0,2371450.html, https://www.gpw.pl/aktualnosc?cmn_id=10603, https://www.gpw.pl/pub/GPW/files/PDF/2017_09_FTSE_Russell.pdf
} 


\title{
PUBLIC RELATIONS W INSTYTUCJACH NON-PROFIT
}

Komentator polityczny BBC Andrew Marr w głośnym tekście „Dzięki Ci Polsko za przysłanie nam swojej młodzieży” z „The Sunday Times” chwalił polskich imigrantów:

\begin{abstract}
„Gdybyśmy usiedli z kartką papieru i ołówkiem i spróbowali ustalić, jaki kraj byłby idealnym źródłem imigrantów dla Wielkiej Brytanii, to myślę, że po wzięciu pod uwagę wszystkich procentów, historycznych dat i ekonomicznych równań, mielibyśmy słowo Polska zaznaczone, podkreślone i opatrzone trzema wykrzyknikami.

(...) Polscy piloci walczyli w Bitwie o Anglię, a dla polskich dysydentów w czasach komunizmu i Solidarności Brytyjczycy wyrażali najgłębszy podziw. Mojemu pokoleniu jest znanych wielu polskich pisarzy i kompozytorów, m.in. Czesław Miłosz, Wisława Szymborska, Zbigniew Herbert i Witold Lutosławski, a papież Jan Paweł II traktowany był zawsze jako światowy lider o formacie Nelsona Mandeli. (...)

92 proc. imigrantów znad Wisły ma stałą pracę lub studiuje. Polacy założyli też na Wyspach ponad 22 tys. firm. (...) My pomogliśmy Polakom - przez wyższe zarobki - a oni pomogli nam. Podczas gdy Władimir Putin pręży muskuły my próbujemy ustalić nasze priorytety w procesie wyjścia z Unii Europejskiej, warto zadać sobie pytanie, kto jest naszym dobrym przyjacielem". ${ }^{76}$
\end{abstract}

Natomiast Giles Coren w zapowiadanym dzień wcześniej artykule „How to be a lazy Brit” („Jak zostać leniwym Brytyjczykiem”) z rozkładówki z „The Times” komentował dowcipnie:

„Polacy przyjeżdżający do Wielkiej Brytanii bardzo ciężko pracują. Po kilku latach w tym kraju upodabniają się do Brytyjczyków i staja się tak samo leniwi jak oni". ${ }^{77}$

Takie komentarze trafiają się jednak w zdecydowanej mniejszości. Przez ostatnie półtora roku przeważały artykuły jednostronne, z biało-czarną tezą; najczęściej sugerujące, że Polska ma problemy z respektowaniem praworządności, wartości demokratycznych, że „stacza się w kierunku brunatnej dyktatury”. Podkreślały, że obecny polski rząd „symbolicznie opuścił flagę unijną z masztu”78, ale mimo tego deklaruje, że „nie zamierza wprowadzać Polski z Unii Europejskiej” ${ }^{79}$ i „chętnie bierze unijne pieniądze”. ${ }^{80}$ Pojawiały się sugestie, że „inne państwa z UE chętnie zobaczyłyby Polskę poza UE". ${ }^{81}$

\footnotetext{
${ }^{76}$ Andrew Marr "Thank you, Poland, for lending us your young - a migration that really works", The Sunday Times 28.08.2016, cyt. za: http://demotywatory.pl/4685519/Brytyjski-publicysta-BBC-dziekujePolsce-Dziekuje-ci.

${ }^{77}$ Giles Coren „How to be a lazy Brit. The easy way to become a great British builder”, The Times 27.05.2017.

${ }^{78}$ H. Foy „Barber rhetoric” Financial Times, 27.11.2015.

${ }^{79}$ The Economist “Illiberalism lives”, 29.04.2017.

${ }^{80}$ H. Foy https://twitter.com/henryjfoy?lang=pl, 8.03.2017.

${ }^{81}$ The Economist “Illiberalism lives", op.cit.
} 


\section{Podsumowanie ${ }^{82}$}

Wydaje się, że dzisiaj - ponad półtora roku po wygranych przez PIS wyborach z października 2015 apogeum niezdrowego zainteresowania Polską mamy za sobą. Aktywność zagranicznych korespondentów zdaje się tracić na sile, więc można wyciszyć emocje i powoli kusić się na podsumowania. Wciąż nie można jednak autorytatywnie stwierdzić jakie były przyczyny negatywnej kampanii prasowej na temat Polski, jak również trudno oszacować wszystkie jej konsekwencje.

Jako następstwa można wskazać zmianę wizerunku Polski na arenie międzynarodowej, niespójny i niejednoznaczny obraz Polski wśród europejskich elit politycznych, zmianę ratingów Polski w międzynarodowych instytucjach finansowych (najpierw nadanie negatywnej perspektywy, później ponowna zmiana z negatywnej na stabilną) oraz wciąż aktualną groźbę sankcji za nieprzestrzeganie praworządności (groźba zabrania bądź ograniczenia funduszy strukturalnych oraz odebrania Polsce prawa głosu w Radzie Europejskiej).

Na pewno można stwierdzić, że wbrew złowieszczym prognozom rok 2016 był dobry dla inwestycji zagranicznych w naszym kraju - wartość ogłoszonych inwestycji wzrosła o $74 \% \mathrm{w}$ stosunku do poprzedniego roku ${ }^{83}$ Jak wynika z raportu fDi Intelligence tworzonego w pionie analitycznym Financial Times w ubiegłym roku firmy zagraniczne zapowiedziały w Polsce inwestycje o wartości 9,9 mld dolarów (co czyni $38 \mathrm{mld}$ zl). ${ }^{84} \mathrm{Szacu}$ je się, że Polska zajęła tym piąte miejsce w Europie i osiągnęła lepszą pozycję przetargową i inwestycyjną niż wiele bogatszych krajów Europy, tj. np. Hiszpania, czy Irlandia. ${ }^{85}$ O dobrym zdaniu inwestorów na temat naszej gospodarki świadczy też ogłoszenie oceny wiarygodności kredytowej przez agencję ratingową Moody z 12 maja 2017 r. Moody utrzymała ocenę wiarygodności kredytowej Polski na poziomie A2 i co ważne - ponownie zmieniła jej perspektywę - tym razem z negatywnej na stabilną. Tym samym poprawiła jesienną niekorzystną prognozę. Oznacza to, że nie widzi zagrożenia dla spadku wiarygodności kredytowej Polski.

Również perspektywy handlu zagranicznego zapowiadają się optymistycznie dane GUS za rok 2016 pokazują wzrost polskiego eksportu o 2,3 proc. (do 183,6 mld euro), importu o 0,9 proc. (do 178,9 mld euro) oraz ponad 2 - krotne zwiększenie nadwyżki obrotów (do blisko 4,8 mld euro). ${ }^{86}$ Podczas wizyty prezydenta Chin Xi Jinpinga w Polsce w czerwcu 2016 r podpisano kilkanaście umów o charakterze bilateralnym m.in. w dziedzinie bankowości, połączeń lotniczych, a także mocno zaakcentowano rolę Polski w projekcie odbudowy nowego „Jedwabnego szlaku”, czyli drogi łączącej Chiny

\footnotetext{
${ }^{82}$ Opracowanie to nie wyczerpuje całości omawianego tematu, jest punktem wyjścia dla dalszych rozważań. Opisywanym zagadnieniom należą się w dalszym ciągu uważne obserwacje i analizy.

${ }^{83}$ Szerzej por. G. Siemiończyk „Inwestorzy cenią Polskę”, Rzeczpospolita 15 maja 2017 r., również: http://www.tvp.info/30762014/inwestorzy-cenia-polske-gospodarka-sie-rozpedza

${ }^{84}$ Op.cit.

${ }^{85}$ Szerzej por.: „Zagraniczne firmy nie boją się rządu PIS”, Rzeczpospolita 15 maja 2017 r.

${ }^{86}$ https://www.mr.gov.pl/strony/aktualnosci/handel-zagraniczny-polski-w-2016-r.
} 
z Europą. Do tego we wrześniu 2017 r. po raz pierwszy w swojej historii Polska została uznana za kraj należący nie do grupy krajów rozwijających się („emerging markets), a rozwiniętych (,developed markets”). Za rok mamy dołączyć do grona 25 najbardziej rozwiniętych państw na świecie.

Także liczba turystów napływających do Polski systematycznie się zwiększa. Ministerstwo Sportu i Turystyki podało, że w 2016 r liczba turystów z zagranicy osiągnęła dotychczasowy rekord. Wzrosła o 4,5 proc. więcej niż w 2015 r., czyli wyniosła ok. 17,5 mln (12,5 mln w samym Krakowie). ${ }^{87}$

Z cytowanych badań opinii oraz przytoczonych artykułów prasowych wynika również, że Polacy jako naród mają coraz lepszy wizerunek na Zachodzie. Budują go pracowici, dobrze wykształceni migranci, którzy coraz częściej studiują w krajach Europy Zachodniej i zajmują później wysoko wyspecjalizowane stanowiska pracy. Natomiast 'nijaki' wizerunek państwa polskiego (,Polska bez twarzy”), widoczny w badaniach opinii z ok 2010 r. został zastąpiony wizerunkiem państwa, które wprawdzie dobrze rozwija się gospodarczo, ale łamie zasady demokracji. Polska to kraj o dobrych perspektywach gospodarczych i inwestycyjnych (już nie „emerging market”, a „developed market”), ale też problemach politycznych - jest szarpana wewnętrznymi konfliktami, rządzona przez „brunatną dyktaturę”, która zablokowała Trybunał Konstytucyjny i wolne media, a swojego kandydata na szefa Rady Europejskiej nie poparła jako pierwsze państwo w historii UE. Nawet dla nawet mało uważnego obserwatora wydarzeń międzynarodowych jest to konkluzja dość przewidywalna, ale tak właśnie postrzegana jest dziś Polska na europejskiej scenie politycznej.

Pomimo licznych pozytywnych komentarzy w prasie i telewizji na temat dwóch ważnych dla Polaków wizyt (Donalda Trumpa z 6 lipca i pary książęcej Kate i Williama Windsorów z 17 lipca 2017 r., które stanowiły doskonałą promocję historii, kultury i aspiracji Polski na całym świecie), nie można uznać, że ich następstwem był przełom w pisaniu o Polsce. Po krótkich zachwytach nad Polską jako „geograficznym sercem Europy” ", „Polską jako duszą Europy” ${ }^{89}$ oraz „Polską jako wzorem i symbolem nadziei na to, że zachodnia cywilizacja przetrwa i będzie triumfować” ${ }^{90}$ oraz Polakami jako tymi, którzy „walecznie, z odwagą i determinacją walczyli o niepodległość” przywilejów, ani pieniędzy tylko Boga" "92 europejską opinię publiczną przykuła kwestia reformy polskiego wymiaru sprawiedliwości. Zaczęto pisać o: „Zależnym sądownictwie”93,

\footnotetext{
${ }^{87} \mathrm{http} / / /$ tvn24bis.pl/z-kraju,74/turystyka-w-2016-r-wiecej-turystow-z-zagranicy,716615.htm

${ }^{88}$ Przemówienie Donalda Trumpa na placu Krasińskich w Warszawie z 6 lipca 2017 r., szerzej por.: https://www.wprost.pl/kraj/10063965/1/Komentarze-w-swiatowych-mediach-po-wizycie-Trumpa-wWarszawie-Polska-jako-przyklad.html

${ }^{89}$ Op.cit.

${ }^{90}$ Op.cit.

${ }^{91}$ Przemówienie księcia Wiliama Windsora w Pałacu Łazienkowskim w Warszawie z 17 lipca 2017 r.

${ }^{92}$ Przemówienie Donalda Trumpa, op.cit.

93 „Dependent judicary: Populism in Poland”, The Economist 22.07.2017.
} 
„przejmowaniu politycznej kontroli nad sądami przez partię rządzącą" ${ }^{4}$, „protestach przeciwko polityce partii rządzącej, które miały miejsce w ponad 220 miastach w Polsce od Helu po Zakopane" ${ }^{95}$. Po podjęciu weta przez prezydenta Andrzeja Dudę 24 lipca br. napisano: „przejmowanie sądownictwa w Polsce zostało na chwilę wstrzymane, ale rządy prawa w Polsce nadal są zagrożone". ${ }^{96}$ Nie wszystkie komentarze były tak eleganckie. Szerokim echem wśród polskich internautów odniósł się komentarz norweskiego dziennikarza na temat weta prezydenta Dudy:

$$
\text { „Pies Kaczyńskiego stał się mężczyzną”. } 97
$$

Tak więc w żadnej mierze nie możemy mówić o przełamaniu niekorzystnej narracji i zmianie stylu pisania o Polsce. Dlatego doniesieniom medialnym należy nadal przyglądać się z należytą uwagą. Wszak „wizerunek danego kraju jest pewnego rodzaju walutą, którą można wymienić na inne dobra: współpracę polityczną dla realizacji celów, (...) napływ inwestorów, możliwości eksportowe, zainteresowanie turystów, konsumentów kultury...". ${ }^{98}$ Należy wciąż przypominać, że dbałość o wizerunek Polski na arenie międzynarodowej pozostaje ważnym zadaniem nie tylko dla elit, czy decydentów politycznych, ale wszystkich świadomych obywateli naszego kraju.

\section{BIBLIOGRAFIA:}

\section{BADANIA OPINII PUBLICZNEJ:}

„How Europeans see themselves: looking through the mirror with public opinion surveys", European Commission, Luxemburg 2001.

„Eye on Poland. Promocja i wizerunek Polski w oczach międzynarodowych ekspertów marketingu miejsc”, BEST PLACE- Europejski Instytut Marketingu Miejsc, styczeń 2012.

Badanie opinii „Określenie wizerunku, który Polska powinna promować za granicą", Laboratorium Badań Społecznych dla MSZ, Warszawa, listopad 2013.

„Barometr Polska-Niemcy”, Instytut Spraw Publicznych, jesień 2013.

Stereotyping in Europe, Pew Reseach Center 2012 i 2013.

Livewhat, Geneva-based survey, cyt. za: “Green-eyed continent”, The Economist 29 marca 2016.

Standard Eurobarometr nr 86, Europeans' opinion of the EU's priorities, listopad 2016.

\footnotetext{
94 „Dependent judicary: Populism in Poland”, op.cit.

95 „Objection sustained: Illiberalism in Poland”, The Economist 29.07.2017.

96 „Objection sustained: Illiberalism in Poland, op.cit.

${ }^{97}$ https://wiadomosci.wp.pl/skandaliczne-slowa-norweskiego-dziennika-o-dudzie-lawina-komentarzy6148287146247809 a

${ }^{98}$ W. Olins, badanie opinii „Określenie wizerunku...”, Laboratorium Badań Społecznych dla MSZ, Warszawa, listopad 2013, s. 13.
} 


\section{MATERIAEY PRASOWE POLSKIE:}

Bachman K. „Wejście po przejściach”, Polityka 20 lipca 2002.

Bielecki J., Stankiewicz A. „Witajcie w Unii, jeśli musicie”, Rzeczpospolita 26 kwietnia 2002.

Dawidowski A. „Żadnych złudzeń”, Unia i Polska 23 października 2000.

Dessler J. „Komisja Europejska o przywarach Polaków”, PAP lipiec 2001.

Grzeszak A. „Poland- gdzie to jest? Przymiarka do marki”, Polityka 25 maja 2002.

Saryusz Wolski J. „Ekonomiczny apartheid”, Die Welt 28 listopada 2002.

Skotnicka-Illasiewicz E. „Swojska kultura lękliwości. O sposobach postrzegania UE przez Polaków i unitów", Unia i Polska 3 września 2001.

Smoczyński W. „Polska - kraj bez twarzy”, Polityka 30 czerwca 2009.

„UE-Polak to pazerny fatalista”- serwis informacyjny Wirtualnej Polski z 25 lipca 2001.

Swieżewska D. „Jak postrzegają nas Brytyjczycy, czyli wizerunek Polaka na Wyspach"w: http://polemi.co.uk/lajt/artykuly/wizerunek-polakow-wwielkiej-brytanii-5511, www.kobietawuk.info.

Siemiończyk G. „Inwestorzy cenią Polskę”, Rzeczpospolita 15 maja 2017.

\section{MATERIALY PRASOWE OBCOJEZZYCZNE:}

Blankley T. „France blackmails Poland”, The Washington Times 19 lutego 2002.

Buras P. “Driving Poland apart”, The New York Times 23 grudnia 2015.

Coren G.,,How to be a lazy Brit. The easy way to become a great British builder", The Times 27 maja 2017.

"Courting disaster", The Economist 2 stycznia 2016.

„Dependent judicary: Populism in Poland”, The Economist 22 lipca 2017.

Diehl J. "Poland's disturbing tilt to the right", The Washington Post 29 listopada 2015.

„Europe's new headache. The new government in Poland has made an awful start', The Economist 5 grudnia 2015.

Dietrich A. "Auf dem Weg in die nationalkonservative Diktatur", Die Welt 23 grudnia 2015, cyt. za:

http://www.pap.pl/aktualnosci/news,449879, niemieckie-media-opolsce-polskie-wladze-przekroczyly-rubikon.html

Foy H. „Barbed rhetoric”, Financial Times 27 listopada 2015.

“Green-eyed continent", The Economist 29 marca 2016.

Hanley S., Dawson J., „Poland was never democratic as it looked”, Foreign Policy 3 stycznia 2017.

"Illiberalism lives", The Economist 29 kwietnia 2017.

"Kaczynski hat keine Empathie für sein Volk"- rozmowa z prof. Jadwigą Staniszkis, Die Welt 19 stycznia 2016 r. 
Marr A. "Thank you, Poland, for lending us your young - a migration that really works", The Sunday Times 28 sierpnia 2016, cyt. za: http://demotywatory.pl/4685519/Brytyjski-publicysta-BBC-dziekujePolsce-Dziekuje-ci.

„Objection sustained: Illiberalism in Poland”, The Economist 29 lipca 2017. Santoso A. „Greek Think They're the Hardest Working People in Europe”, The Economist 4 czerwca 2012.

Sharma Ruhir "The Next Economic Powerhouse? Poland”, The New York Times 5 lipca 2017.

„The return of the awkward squad. Two weeks in, Poland's new government is making Europe nervous", The Economist" 5 grudnia 2015.

Ulrich S. "Kaczyński zerstört den polnischen Rechtsstaat", Sueddeutsche Zeitung 23 grudnia 2015, cyt. za: http://www.pap.pl/aktualnosci/news,449879,niemieckie-media-o-polsce-polskie-wladze-przekroczyly-rubikon.html

Veser R. "Polen und Deutschland: ziemlich beste Freunde", Frankfurter Allgemeine Zeitung 16 czerwca 2016.

Zakaria F., CNN o Polsce, CNN, 6 grudnia 2015, cyt. za: http://wyborcza.pl/1,75399,19304320,cnn-o-polsce-wydarzenia-przybraly-bardzo-zly-obrot.html.

“Poland's Tragic Turn”, New York Times 21 grudnia 2016.

Zakaria F. „Global Public Square”, CNN o Polsce, CNN 6 grudnia 2016, cyt. za: https://oko.press/demokracja-krucha-spojrzcie-polske-rosje-turcjeekspert-cnn-zniecheca-trumpa/

\section{LITERATURA:}

Balzer A. "Just A Platonic Love?- Poland and the EU Enlargement" w: "Poland and the Czech Republic: Advocates of the EU Enlargement?' wyd. Demos EUROPA Center for European Strategy Warszawa 2010.

Bond I. "EU Enlargement”, Center for European Reform, www.cer.org.uk.

Fomina J.,Frelak J. „,Wizerunek Polski i Polaków w Wielkiej Brytanii”, wyd. ISP 2011.

Goraus K., Inchauste G. "The Distributional Impact of Taxes and Transfers in Poland", Raport Banku Światowego, sierpień 2016.

Holzer J. „Polacy i Niemcy- wzajemne postrzeganie”, „Kultura i społeczeństwo", tom XLI, wyd. ISP PAN 1997.

Kolarska-Bobińska L. „Odmienność oswajana. Obraz Polski w krajach Unii Europejskiej”, wyd. Instytut Spraw Publicznych, Warszawa 2003.

Koves A. „Central and Eastern European Economies in Transition. The International Dimension”, Westview Press, San Francisco 1992.

Martinez Reyes V. „Reguły gry, czyli o negocjacjach akcesyjnych i łączeniu się Europy", Wyd. Naukowe Scholar, Warszawa 2000. 


\section{PUBLIC RELATIONS W INSTYTUCJACH NON-PROFIT}

Niklewicz K. „Przewodnictwo Polski w Radzie Unii Europejskiej”, 2013.

Ollins W. „Tożsamość rynkowa. Atrybut konkurencyjnego Państwa”, wyd. Instytut Marki Polskiej, Warszawa 2001.

Płonka B. „Polityka Unii Europejskiej wobec krajów Europy Środkowej”, wyd. UJ, Kraków 2003.

Sedelmeier U. „Europe after the Eastern Enlargement of the European Union: 2004-2014", Heinrich Boell Stiftung 2014.

"The EU Capacity for Futher Enlargeement" nr 71, Advisory Council on International Affairs 2010 w: http://aiv-advies.nl/download/1b2da5920f83-4791-b83f-fe822471ff84.pdfs

Walkiewicz W. : „Polska na drodze do Unii Europejskiej. Aspekty negocjacyjne i dostosowawcze", wyd. Rzeszów 2002.

Warchala M. (red). „Wizerunek Polski w prasie krajów Unii Europejskiej”, wyd. Instytut Spraw Publicznych, Warszawa 2002.

Wnuk- Lipiński E. „Członkostwo Polski w Unii Europejskiej- pierwsze Problemy i kryzysy społeczne w Polsce”, w: „Polska w Unii Europejskiej. Początkowe problemy i kryzysy?", wyd. PISM, Warszawa 2002.

\section{OAUTORCE:}

Dr Karolina Swirska-Czalbowska jest wykladowcą Uniwersytetu Stefana Kardynała Wyszyńskiego. Publikowała m.in. w „Polis - piśmie o sztuce życia publicznego”, wyd. przez ISP PAN, kwartalniku CE UW „Studia europejskie”, „Problemach zarządzania”, "Studiach i materialach", Raporcie INE PAN, również w Magazynie Niezależnych Publicystów „Unia i Polska”, „Tygodniku Powszechnym ” „Arcanach”. Jej zainteresowania naukowe obejmują wizerunek Polski i Polaków poza granicami naszego kraju, kwestie budowania marki narodowej, brandingu narodowego i narodowej tożsamości rynkowej, a także promocji Polski w świecie w sferze kulturalnej, politycznej i gospodarczej. Kontakt: kswirska@wp.pl

Dane wartykule - stan na 1 października $2017 \mathrm{r}$. 
кuLTura- мeDia- TeoLogia

ISSN 2081-8971

$2017 \mathrm{nr} 30$, s. 101-121.

\section{Internetowa aktywność amerykańskiego ruchu alternatywnej prawicy $i$ jej wpływ na radykalizację debaty imigracyjnej w Stanach Zjednoczonych}

\section{The online activity of the American alternative right movement and its impact on the radicalization of the immigration debate in the United States}

\section{STRESZCZENIE:}

AUTOR ARTYKULU ANALIZUJE WPEYW DYSKURSU

IMIGRACYJNEGO, PROWADZONEGO W MEDIACH INTERNETOWYCH ALTERNATYWNEJ PRAWICY, NA DEBATE NA TEMAT IMIGRACJI W STANACH ZJEDNOCZONYCH. „ALT-RIGHT" JAKO NOWY RUCH SPOŁECZNY POSŁUGUJE SIĘ PODSTAWOWYMI MECHANIZMAMI MEDIALNYMI,

W TYM ZWŁASZCZA ZAGŁUSZANIEM KULTURY, DZIENNIKARSTWEM OBYWATELSKIM ORAZ MOBILIZACJĄ OPARTĄ NA MEDIACH. DZIĘKI NIM KOMUNIKATY ALTERNATYWNEJ PRAWICY PRZENIKAJĄ DO DEBATY PUBLICZNEJ. JEJ RADYKALIZACJĘ W KWESTII IMIGRACJI MOŻNA BYŁO ZAOBSERWOWAĆ PODCZAS PREZYDENCKIEJ

KAMPANII WYBORCZEJ W 2016 R., KIEDY TO MEDIA ALTERNATYWNEJ PRAWICY NA RÓWNI Z MEDIAMI GEÓWNEGO NURTU KSZTAETOWAEY DYSKURS IMIGRACYJNY.

\section{SŁOWA KLUCZOWE:} ALTERNATYWNA PRAWICA, ,ALT-RIGHT”, IMIGRACJA, DYSKURS, NOWE RUCHY SPOŁECZNE

\begin{abstract}
:
THE ARTICLE ANALYZES THE IMPACT OF THE IMMIGRATION DISCOURSE OF THE ONLINE “ALT-RIGHT" MEDIA ON THE DEBATE ON IMMigration In the United STates. The ALTERNATIVE RIGHT, BEING A NEW SOCIAL MOVEMENT, USES FUNDAMENTAL MEDIA GENRES SUCH AS CULTURE JAMMING, CIVIC JOURNALISM AND MOBILIZATION BASED ON THE MEDIA. DUE TO THEM, COMMUNICATIONS ISSUED BY THE ALTERNATIVE MEDIA INFILTRATE INTO THE PUBLIC DEBATE. THE PROCESS OF ITS RADICALIZATION COULD BE OBSERVED DURING THE PRESIDENTIAL CAMPAIGN IN 2016, WHEN THE "ALT-RIGHT" MEDIA, TOGETHER WITH THE MAINSTREAM MEDIA" SHAPED THE US IMMIGRATION DISCOURSE.
\end{abstract}

\section{KEYWORDS:}

ALTERNATIVE RIGHT, ALT-RIGHT, IMMIGRATION, DISCOURSE, NEW SOCIAL MOVEMENTS 


\section{PUBLIC RELATIONS W INSTYTUCJACH NON-PROFIT}

Tednym z głównych tematów podejmowanych podczas kampanii prezydenckiej w Stanach Zjednoczonych w 2016 roku była kwestia imigracji i imigrantów. Inaczej jednak, niż w poprzednich latach, obok środków masowego przekazu zaliczanych do tzw. głównego nurtu, ton debacie publicznej nadawały media alternatywne. Dotyczyło to zwłaszcza mediów związanych z ruchem alternatywnej prawicy. Analizując sondaże opinii publicznej można wręcz stwierdzić, że to właśnie media alternatywne lepiej odczytywały i kształtowały nastroje społeczne, niż te dotychczas uznawane za najważniejsze dla tworzenia politycznego przekazu, a więc „The New York Times” czy „CNN”. Zwycięstwo wyborcze Donalda Trumpa, kandydata najbardziej wyrazistego w kwestii polityki imigracyjnej, a zarazem utożsamianego z ruchem alternatywnej prawicy, jest tego najlepszym przykładem.

Zadaniem niniejszego artykułu jest analiza dyskursu imigracyjnego prowadzonego przez media związane z ruchem ,alt-right” oraz jego wpływu na debatę imigracyjną w Stanach Zjednoczonych. W tym celu przyjęto hipotezę, iż media alternatywnej prawicy, wykorzystując możliwości oferowane im m.in. przez internet, doprowadziły do radykalizacji dyskursu imigracyjnego w USA. Definicja dyskursu została zaczerpnięta z dokonań Normana Fairclougha, który przekonuje, że: „dyskursy nie tylko przedstawiają świat takim, jakim on jest (lub raczej jest postrzegany), lecz także są projekcją, wyobrażeniami, reprezentującymi możliwe światy, które różne są od faktycznego świata i które są związane z projektami, mającymi na celu zmianę świata w konkretnych kierunkach"”.

Podstaw teoretycznych do przeprowadzonych badań dostarczyły teorie funkcjonowania mediów alternatywnych oraz nowych ruchów społecznych. Nie ulega bowiem wątpliwości, że media „alt right” można uznać za alternatywne, zaś sam ruch alternatywnej prawicy wpisuje się w definicję nowych ruchów społecznych (NRS). Z tego też powodu na początku artykułu zostały przybliżone teoretyczne założenia funkcjonowania mediów alternatywnych oraz NRS. Następnie, szerzej omówiono genezę i rozwój amerykańskiej alternatywnej prawicy, a także jej stosunek do imigracji i imigrantów w Stanach Zjednoczonych. Uwzględnienie historii ruchu „alt-right” wydaje się zasadne, zważywszy na wciąż skromny dorobek naukowy poświęcony temu zagadnieniu ${ }^{3}$. Zasadniczą

\footnotetext{
${ }^{1}$ Większość mediów głównego nurtu ostrzegała kandydatów przed zbyt krytycznym stosunkiem do imigracji, jako postawą antagonizującą wyborców wywodzących się z różnych grup etnicznych, co w końcowym rozrachunku okazało się błędem. Por. Ch. Cillizza, How Immigration Could Cripple the Republican Nominee Long Before the 2016 Election, "The Washington Post" 17.07.2015, https://www.washingtonpost.com/news/the-fix/wp/2015/06/17/how-immigration-could-cripple-therepublican-nominee-long-before-the-2016-general-election/?utm_term=.4c34f3c1d6e7, [dostęp: 10.11.2017].

${ }^{2}$ N. Fairclough, Analyzing Discourse. Textual Analysis for Social Research, London 2003, s. 124 (tłumaczenie własne).

${ }^{3}$ Wśród niewielu artykułów i monografii podejmujących temat alternatywnej prawicy w USA i jej aktywności medialnej można wymienić: Media, Culture, and the Religious Right, (red.) L. Kintz, J. Lesage, Minneapolis-London 1998; S. George, Hijacking America. How the Religious and Secular Right Changed What Americans Think, Cambridge 2008; D. Brock, The Republican Noise Machine. Right-Wing Media and How It Corrupts Democracy, New York 2005; J.K. White, Donald Trump and the Scourge of Populism, "The
} 
część artykułu tworzy zaś analiza wpływu mediów związanych z alternatywną prawicą na toczoną w USA debatę imigracyjną. Została ona przeprowadzona przy zastosowaniu podziału na gatunki medialne ${ }^{4}$ właściwe nowym ruchom społecznym; w szczególności chodzić będzie o zagłuszanie kultury, dziennikarstwo obywatelskie oraz mobilizację opartą o media.

\section{Media alternatywne i nowe ruchy społeczne}

Rosnąca popularność amerykańskiej alternatywnej prawicy wynika przede wszystkim z aktywności jej sympatyków w internecie. Zanim więc przybliżona zostanie geneza i rozwój samego ruchu, warto zdefiniować media alternatywne oraz wskazać podstawy teoretyczne ich funkcjonowania. Jak przekonują badacze mediów alternatywnych, sama ich specyfika sprawia, że stworzenie jednej, powszechnej definicji jest niemożliwe. „W pewnym momencie wszystko może stanowić alternatywę czegoś innego" - stwierdza nie bez racji John Downing ${ }^{5}$. Z tego też powodu niektórzy medioznawcy definiują media alternatywne przez pryzmat tego, czym one nie są. I tak, zdaniem brytyjskiej grupy badawczej „Comedia”, media alternatywne „nie są częścią uznanego porządku, nie są też częścią systemu kapitalistycznego, nie przedstawiają poglądów głównego nurtu, w końcu też nie są konwencjonalnym sposobem robienia czegoś” ${ }^{6}$. Większość definicji mediów alternatywnych opiera się bądź na analizie ich statusu prawnego, bądź analizie zawartości, tj. prezentowanych idei, linii programowej itp. W pierwszym przypadku, za media alternatywne uznaje się te, które funkcjonują poza danym porządkiem prawnym, tj. nie są zarejestrowane i nie podlegają stosownym regulacjom. Warto przy tym dodać, że taki wybór nie musi wynikać z kontestacji istniejących reguł przez ich twórców, lecz $\mathrm{z}$ ich amatorskiego, niekomercyjnego charakteru ${ }^{7}$. Z kolei zwolennicy definiowania mediów alternatywnych poprzez prezentowane przez nie poglądy i stanowiska, podkreślają, że to właśnie „pozostawanie w opozycji do głównego nurtu” należy uznać za czynnik konstytuujący ten rodzaj mediów ${ }^{8}$. Tak właśnie media alternatywne charakteryzuje Bar-

\footnotetext{
Forum. A Journal of Applied Research in Contemporary Politics” 2016, vol. 14, issue 3, s. 265-279. Pozostałe artykuły i monografie wykorzystane w niniejszym artykule zostały wykazane w bibliografii.

${ }^{4}$ Warto przy tym podkreślić, że Lievrouw definiuje „gatunek” inaczej, niż to przyjęto w naukach o mediach (tj. podział gatunków dziennikarskich na informacyjne, publicystyczne, pograniczne itp.). Badaczka rozumie go przede wszystkim jako „taktykę medialną”, definiując gatunek jako „,formę ekspresji lub komunikacji, która jest przydatna i/ lub znacząca dla członków danej społeczności w konkretnej sytuacji. Gatunki cechują się zarówno formą, jak i celem. Oznacza to, że posiadają typowe cechy materialne lub wynikają z pewnych konwencji formalnych i umożliwiają ludziom wyrażanie własnych poglądów lub odczuć w celu osiągnięcia zamierzonych celów lub intencji w danej sytuacji. (...) Wydaje się więc, że gatunki są sposobem tworzenia społeczności i kontekstu społecznego oraz kulturowych produktów i kontekstów funkcjonowania". L.A. Lievrouw, Media alternatywne..., dz. cyt., s. 32-34.

${ }^{5}$ J.H. Downing, Radical Media. Rebellious Communication and Social Movements, London 2001, s. ix.

${ }^{6}$ Comedia, The Alternative Press. The Development of Underdevelopment, "Media, Culture and Society" 1984, vol. 6, s. 95.

${ }^{7} \mathrm{Ch}$. Atton, Alternative Media, London-Thousand Oaks-New Delhi 2003, s. 12.

${ }^{8}$ W. Pisarek (red.), Słownik terminologii medialnej, Kraków 2006, s. 173.
} 
tłomiej Golka, według którego wyrażają one „protest, ducha walki określanego na łamach setek pism podziemnych mianem "rewolucji przeciwko ustalonemu porządkowi» w sferze społeczno-ekonomicznej i etycznej"”.

Upowszechnienie dostępu do internetu oraz łatwość, z jaką można zaznaczyć swoją obecność w globalnej sieci, wymusiły modyfikację istniejących definicji mediów alternatywnych. Obecnie większość z nich uwzględnia zarówno model produkcji i funkcjonowania mediów alternatywnych, jak również ich zawartość. Taką właśnie definicję przedstawia Leah A. Lievrouw w książce pt. Media alternatywne i zaangażowanie społeczne. Zdaniem amerykańskiej badaczki, „media alternatywne i zaangażowane wykorzystują lub modyfikują przedmioty, praktyki i ustalenia społeczne służące do komunikacji, przy użyciu technologii informacyjnych i komunikacyjnych w celu zakwestionowania lub zmiany dominujących, powszechnie oczekiwanych lub przyjętych sposobów kreowania życia społecznego, kulturalnego i politycznego" ${ }^{10}$. Oznacza to, że wyznacznikiem „alternatywności” danego medium wcale nie musi być przyjęta przez jego twórców linia polityczna. Media alternatywne mogą bowiem podejmować tematy niezwiązane z bieżącą polityką, a które są pomijane przez tzw. mainstream. Jak bowiem wskazuje John Fiske, cechą konstytutywną mediów alternatywnych jest głównie walka z cenzurą polityczną, gospodarczą, kulturową, religijną itp. ${ }^{11}$

Teorie wyjaśniające funkcjonowanie mediów alternatywnych opierają się głównie na marksistowskich (neomarksistowskich) założeniach, w tym na koncepcji hegemonii kulturowej Antonio Gramsciego i teorii ideologii Louisa Althussera ${ }^{12}$. Na rolę mediów alternatywnych jako przeciwwagi dla „produkcji zgody” zwracali uwagę m.in. Edward S. Herman i Noam Chomsky ${ }^{13}$. Część badaczy, wychodząc z założeń paradygmatu anarchistycznego, uznaje media alternatywne za media uczestniczące (participatory media). Zgodnie z tą teorią, media alternatywne umożliwiają szerokiemu gronu odbiorców współudział we wszystkich etapach produkcji - od pozyskiwania informacji i ich przetworzenia, przez skład i druk, aż po dystrybucję ${ }^{14}$. Media alternatywne pełnią więc rolę tzw. community media, reprezentując głos danej społeczności. Zdaniem Alfonso Dagrona, ,alternatywna forma komunikacji jest w swojej esencji komunikacją uczestniczącą, a alternatywny duch pozostaje tak długo, jak element uczestnictwa nie jest spro-

\footnotetext{
${ }^{9}$ B. Golka, System medialny Stanów Zjednoczonych, Warszawa 2004, s. 206.

${ }^{10}$ L.A. Lievrouw, Media alternatywne i zaangażowanie społeczne, Warszawa 2012, s. 31.

${ }^{11}$ J. Fiske, British Cultural Studies and Television, w: Channels of Discourse. Reassembled, R.C. Allen (red.), London 1992, s. 30-49.

${ }^{12}$ Por. J.B. Gray, Althusser, Ideology, and Theoretical Foundations. Theory and Communication, "Journal of New Media \& Culture" 2005, vol. 3, issue 1, http://www.ibiblio.org/nmediac/winter2004/gray.html [dostęp: 12.12.2017 r.].

${ }^{13}$ E.S. Herman, N. Chomsky, Manufacturing Consent, London 1989.

${ }^{14}$ N. Couldry, Beyond the Hall of Mirrors? Some Theoretical Reflections on the Global Contestation of Media Power, w: Contesting Media Power. Alternative Media in a Networked World, N. Couldry, J. Curran (red.), London 2003, s. 39-54.
} 

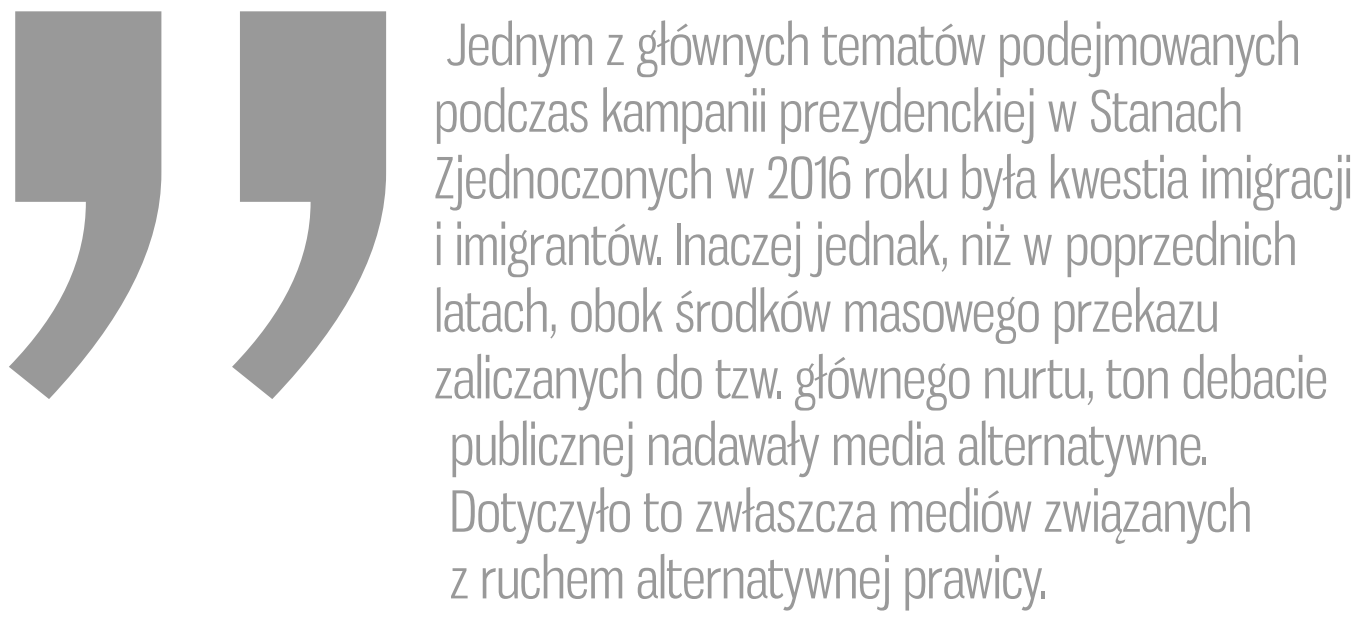

wadzony do minimum lub całkowicie wykluczony"15. Jednocześnie media alternatywne, to media krytyczne, których znaczenie wzrasta w okresach społecznych niepokojów. Powtarzając za Herbertem Marcuse, „rozwój radykalnej politycznej świadomości wśród mas może mieć miejsce jedynie wówczas, kiedy ekonomiczna stabilizacja i społeczna spójność systemu zaczyna się osłabiać" ${ }^{16}$.

Rozwój internetu jeszcze bardziej uwypuklił znaczenie mediów alternatywnych jako mediów uczestniczących i krytycznych. Zdaniem Thomasa Allmera, to właśnie w globalnej sieci „ruchy społeczne są w stanie publikować i rozprowadzać alternatywne poglądy, a także, przy niskich nakładach, podnosić krytyczną świadomość na globalną skalę"17. Coraz powszechniejszy dostęp do internetu oraz łatwość, z jaką można stworzyć własną stronę internetową lub chociażby opublikować opinię sprawia, że tworzy on idealne środowisko dla różnego rodzaju aktywności nowych ruchów społecznych (NRS). Według badaczy i teoretyków NRS, za ich cechy charakterystyczne można uznać kreatywność ich uczestników, zbiorową tożsamość przy jednoczesnej niezależności od instytucjonalnych struktur i kategorii, luźne powiązania i nieformalne struktury, „niekonwencjonalne działania” oraz „kompleksowe, zaawansowane korzystanie z mediów oraz technologii informacyjnej i komunikacyjnej”" ${ }^{18}$. Zdaniem cytowanej już Lievrouw, internetowa działalność nowych ruchów społecznych opiera się na pięciu gatunkach medialnych, tj. zagłuszaniu kultury, komputerowej alternatywie, dziennikarstwie obywatelskim opartym na uczestnictwie, mobilizacji przez media, wspólnych zasobach wiedzy ${ }^{19}$.

\footnotetext{
${ }^{15}$ A.G. Dagron, The Long and Winding Road of Alternative Media, w: The SAGE Handbook of Media Studies, J.H. Downing (red.), London 2004, s. 48.

${ }^{16}$ H. Marcuse, An Essay on Liberation, Boston 1969, s. 54.

${ }^{17}$ T. Allmer, Critical Theory and Social Media. Between emancipation and commodification, London and New York 2015, s. 154.

${ }^{18}$ L.A. Lievrouw, Media alternatywne..., dz. cyt., s. 64-65.

${ }^{19}$ Tamże, s. 36.
} 


\section{Geneza alternatywnej prawicy}

Chociaż tzw. ruch ,alt-right” wzbudza zainteresowanie mediów głównego nurtu od niedawna, jego geneza sięga wielu lat wstecz. Zdaniem konserwatywnych publicystów Richarda A. Viguerie i Davida Franke, początków amerykańskiej alternatywnej prawicy należy szukać już w latach 50. XX wieku, kiedy to media masowe miały zostać zdominowane przez liberalnych sympatyków obu głównych partii politycznych ${ }^{20}$. Tradycyjni konserwatyści poczuli się wówczas zepchnięci na margines. Co prawda ich poglądy były reprezentowane przez niektóre tytuły prasowe, także tzw. prestiżowe (m.in. „The Chicago Tribune”), jednakże nie zdobywały one uznania w debacie ogólnokrajowej. Nie bez racji krytyk literacki Lionel Trilling pisał w 1950 r.: „Obecnie w Stanach Zjednoczonych liberalizm jest nie tylko dominującą, ale wręcz jedyną intelektualną tradycją. Jest bowiem dowiedzione, że w bieżącym powszechnym obiegu zupełnie nie ma konserwatywnych lub reakcyjnych idei" ${ }^{\prime 2}$.

Przełom nastąpił pod koniec lat 90 . XX wieku. Wówczas to pojawiły się pierwsze konserwatywne strony internetowe, na czele z „The Drudge Report”. Założona w 1996 roku przez szerzej nieznanego sprzedawcę z Los Angeles strona www zdobyła popularność dzięki nagłośnieniu romansu prezydenta Billa Clintona ze stażystką Monicą Lewin$\mathrm{sky}^{22}$. Co prawda, większość stołecznych korespondentów wiedziała o skandalu, zdecydowali się jednak oni utrzymać wszystko w tajemnicy, nie chcąc narażać głowy państwa na ataki ze strony przeciwników politycznych. Popularność „The Drudge Report” sprawiła, że na początku XXI wieku niektórzy obserwatorzy uważali go za „,barometr amerykańskiego społeczeństwa”, lecz w dalszych latach jego rozpoznawalność i możliwość wpływania na debatę publiczną znacznie zmalały ${ }^{23}$.

Mimo spadku czytelnictwa „The Drudge Report” tradycyjni konserwatyści coraz śmielej radzili sobie w internecie. Większość z powstałych w pierwszej połowie XXI wieku stron internetowych była niewielkimi, amatorskimi projektami, przypominającymi tradycyjną prasę radykalnej prawicy z lat 20 . i 30 . XX wieku. Z jednej więc strony ich zasięg pozostawał niewielki, z drugiej był wystarczający, aby spełniać funkcje socjalizujące i organizacyjne wśród osób o prawicowych poglądach, a rozczarowanych Partią Republikańską. To właśnie liczne strony, fora czy grupy dyskusyjne doprowadziły do scalenia tego ruchu pod flagą Tea Party. W 2002 roku powstała strona internetowa www.usteaparty.com, która stała się zarzewiem ogólnokrajowego protestu przeciwko reformom społecznym wprowadzonym przez prezydenta George’a W. Busha. Tea Party zarzucała republikańskiej administracji „porzucenie amerykańskich ideałów”, które miało się objawiać m.in. ukróceniem wolności osobistej obywateli oraz zbyt pobłażliwym stosunkiem do nielegalnych imigrantów. Chociaż aż do 2016 roku zwolennicy Tea Party nie

\footnotetext{
${ }^{20}$ R.A. Viguerie, D. Franke, America's Right Turn, Chicago and Los Angeles 2004, s. 75-86.

${ }^{21}$ Cyt. za: R. Kirk, The Conservative Mind. From Burke to Eliot, Washington 2001, s. 476.

${ }^{22}$ Culture Wars in America. An Encyclopedia of Issues, Viewpoints, and Voices, vol. 1-3, w: R. Chapman, J. Ciment (red.), London and New York 2014.

${ }^{23}$ J. Duarte, Futures \& Options, Hoboken 2006, s. 168.
} 
zdobyli dominującej pozycji w Partii Republikańskiej, to kilkudziesięciu kandydatów z jej poparciem dostało się do Kongresu. Jak wskazują niektórzy badacze, aktywność sympatyków alternatywnej prawicy była kluczowa dla odzyskania przez Partię Republikańską większości w Izbie Reprezentantów w 2010 r. Utożsamiający się z nią kongresmeni i senatorzy odegrali ponadto wiodącą rolę $w$ zablokowaniu reform prezydenta Baracka Obamy w 2011 i 2013 roku, czego bezpośrednią konsekwencją był kilkutygodniowy tzw. ,government shutdown”"24.

Tea Party opiera swoją działalność na aktywności swoich szeregowych sympatyków. Nie tylko prowadzą oni strony internetowe, ale także organizują wydarzenia w swoich lokalnych społecznościach oraz prowadzą zbiórki pieniędzy. Zdaniem jednego z komentatorów, ruch ten ,jest mieszaniną oddolnego populizmu, profesjonalnej konserwatywnej polityki oraz wielkich pieniędzy"25. Alternatywna prawica jako ruch społeczny jest niezwykle zróżnicowana. Wśród jej sympatyków znaleźli się bowiem zarówno zwolennicy pomocy socjalnej państwa dla najbiedniejszych, jak i przedsiębiorcy oczekujący powrotu do neoliberalnej polityki gospodarczej epoki Ronalda Reagana. Zdaniem badaczy amerykańskiej sceny politycznej, Tea Party - a w ślad za nią cały ruch alternatywnej prawicy - spajało przede wszystkim poczucie wspólnoty etnicznej. Nie przez przypadek zdecydowana większość sympatyków ruchu rekrutuje się spośród białej części amerykańskiego społeczeństwa. Różni ich zarówno status majątkowy, jak i pozycja społeczna, jednakże łączy obawa przed polityką wielokulturowości, utożsamianą z rosnącą imigracją i liberalizacją praw różnego rodzaju mniejszości, w tym seksualnych ${ }^{26}$. Podobnie, jak większość nowych ruchów społecznych, także alternatywna prawica nie reprezentuje „rozległych, zbiorowych "interesów klasowych" czy ideologii, lecz dąży do wyrażenia swoich subiektywnych doświadczeń i interesów oraz utrzymania swojej niezależności od dominujących instytucji” ${ }^{27}$.

\section{Charakterystyka ruchu ,alt-right”}

Sam termin „,alt-right” funkcjonuje o wiele krócej niż ruch, który opisuje. Po raz pierwszy w publicznym obiegu zaistniał on w 2008 roku, a jego autorstwo przypisuje się Richardowi Spencerowi, konserwatywnemu publicyście, oskarżanemu o rasizm i antysemityzm. Kamieniem węgielnym dla aktywizacji sympatyków ruchu było utworzenie w 2010 roku strony internetowej www.alternativeright.com. Zdaniem Andrew Marant-

\footnotetext{
${ }^{24}$ Por. Ch.S. Parker, M.A. Baretto, Change They Can't Believe in. The Tea Party and Reactionary Politics in America, Princeton 2013.

${ }^{25}$ Ch. Meyer, A New American Revolution? Anti-establishment Tea Party is on the brink of election victories that could leave Obama a lame duck, "Mail Online", 25.10 .2010 [http://www.dailymail.co.uk/news/article1323047/Anti-establishment-Tea-Party-leave-Obama-lame-duck.html [dostęp: 07.12.2017].

${ }^{26}$ R. Willer, M. Feinberg, R. Wetts, Threats to Racial Status Promote Tea Party Support among White Americans, 4 May 2016, SSRN, https://papers.ssrn.com/sol3/papers.cfm?abstract_id=2770186 [dostęp: 08.12.2017]. Por. także: B. Press, Train Wreck. The End of the Conservative Revolution, Hoboken 2008, s. 94-95.

${ }^{27}$ L.A. Lievrow, Media alternatywne..., dz. syt., s. 66 .
} 
za, publicysty prestiżowego „The New Yorker”, termin „alt-right” odnosi się do „luźnych, internetowych powiązań białych nacjonalistów, neo-monarchistów, szowinistów, zwolenników teorii spiskowych, wojujących nihilistów i trolli działających w mediach społecznościowych”28. Z kolei, według konserwatywnego „The National Review”, szeregi alternatywnej prawicy zasilają głównie „zgorzkniali przedstawiciele białej klasy pracującej” ${ }^{29}$. Sami sympatycy alternatywnej prawicy definiują „alt-right” przede wszystkim przez pryzmat sprzeciwu wobec rządów dotychczasowego establishmentu.

W zamieszczonej w internecie w marcu 2016 roku publikacji An Establishment Conservative's Guide to the Alt-Right, Allum Bokhari i Milo Yiannopoulos dowodzą, że ruch ten powstał dzięki wieloletniej internetowej aktywności wielu młodych ludzi, rozczarowanych kierunkiem, w którym zmierzały Stany Zjednoczone. Ich zdaniem wizerunek alternatywnej prawicy jako zbiorowiska „niewykształconych skinów i antysemitów” nie znajduje pokrycia w faktach. „Alternatywną prawicę tworzy grupa niezwykle mądrych ludzi. (...) Są niepokojąco sprytni” - przekonują ${ }^{30}$. Sam ruch ma zaś czerpać z intelektualnych dokonań tak różnych myślicieli, jak Oswald Spengler, H.L. Mencken, Julius Evola i Sam Francis. Tak, jak różnorodne są źródła inspiracji alternatywnej prawicy, tak różnorodni są jej sympatycy. Cytowany przewodnik wymienia takie grupy, jak izolacjoniści, zwolennicy prorosyjskiej polityki, osoby rozczarowane neokonserwatystami, przeciwnicy zaangażowania militarnego USA w świecie, neoreakcjoniści, tradycyjni konserwatyści, a nawet libertarianie ${ }^{31}$.

Cechą wspólną powyższych grup jest ich wysoka aktywność w internecie. Dlatego też Bokhari i Yiannopoulos łączą rosnącą siłę alternatywnej prawicy z „wszechogarniającą cenzurą”, którą utożsamiają z polityczną poprawnością. To właśnie polityczna poprawność miała stać się głównym celem buntu młodego pokolenia: „Młodzi buntownicy przywiązują się do alternatywnej prawicy z tego samego powodu, dla którego pokolenie Baby Boomers fascynowało się Nową Lewicą w latach 60 . XX wieku: ponieważ obiecuje im dobrą zabawę, transgresję oraz kwestionuje normy społeczne, których oni nie rozumieją" ${ }^{2}$. Aktywność alternatywnej prawicy w internecie nie ogranicza się do prowadzenia stron internetowych czy grup dyskusyjnych. Zwolennicy „alt-right” doskonale korzystają z narzędzi oferowanych przez Web 2.0, a więc koncentrują się przede wszystkim na mediach społecznościowych. Krótkie, dosadne komentarze publikowane na Twitterze lub Facebooku mają o wiele większą szansę zaistnienia w ogólnokrajowej debacie, niż długie eseje zamieszczane na niszowych stronach. Jak trafnie zauważył jeden z publicystów brytyjskiego „The Independent”, sympatycy ruchu „powiedzą lub zrobią

\footnotetext{
${ }^{28}$ A. Morowitz, Trolls for Trump, ,The New Yorker” October 31, 2016.

${ }^{29}$ K.D. Williamson, The Father Führer, "The National Review" 2016, vol. LXVIII, no. 5.

${ }^{30}$ A. Bokhari, M. Yiannopoulos, An Establishment Conservative's Guide to the Alt-Right, 29.03.2016, http://www.breitbart.com/tech/2016/03/29/an-establishment-conservatives-guide-to-the-alt-right [dostęp: 08.09.2017].

${ }^{31}$ Tamże.

32 Tamże.
} 
wszystko, aby zaszokować liberalny internet, zdając sobie sprawę, że takie zachowanie zdobywa im popularność wśród rosnącej armii zwolenników składającej się w większości z białych maniaków komputerowych"33. Korzystając z popularnych mediów społecznościowych, zwolennicy alternatywnej prawicy posługują się specjalnym językiem metafor i aluzji, dzięki któremu unikają oskarżeń o rasizm czy antysemityzm. Natomiast bezpośrednim językiem posługują się we własnych mediach, takich jak Gab, stworzony jako nacjonalistyczna alternatywa dla Twittera ${ }^{34}$. Również sympatyzujące $\mathrm{z}$ „alt-right” strony informacyjne, w tym Breitbart News Network (www.breitbart.com), w niczym nie ustępują profesjonalnym serwisom - pozyskują reklamodawców pośród największych firm w Stanach Zjednoczonych ${ }^{35}$. Z tego powodu trudno zatem uznać ten przykład za egzemplifikację „dziennikarstwa obywatelskiego”. Jednakże ze względu na jego linię polityczną - wprost podważającą bieżące fundamenty amerykańskiej polityki oraz modelu funkcjonowania mediów - mieści się on w definicji mediów alternatywnych ${ }^{36}$.

\section{Alternatywna prawica wobec problemu imigracji}

Jak już wcześniej zaznaczono, jednym z elementów spajających różnorodne grupy tworzące wpierw Tea Party, a następnie ruch „alt-right”, jest skrajnie negatywny stosunek do kwestii imigracji. Za symptomatyczne dla całej alternatywnej prawicy można uznać poglądy Patricka J. Buchanana, publicysty i polityka, utożsamianego z tzw. paleokonserwatystami. W swoich licznych książkach i komentarzach od wielu lat przekonuje on, że „największym i najpilniejszym problemem, z którym muszą zmierzyć się Stany Zjednoczone na tej półkuli jest masowa imigracja" ${ }^{37}$. Przy czym, sprzeciw wobec bieżącej imigracji wynika nie tyle z jej rozmiarów, co ze składu etnicznego. Dla Buchanana największe bowiem zagrożenie stanowi zróżnicowanie kulturowe i rasowe setek tysięcy osób przybywających co roku do USA. Nic zatem dziwnego, że w dyskursie imigracyjnym alternatywnej prawicy powracają dobrze już znane elementy, takie jak „niemożność asymilacji” czy „zbyt wielka odmienność kulturowa” niektórych grup ${ }^{38}$. Wszystkie one były

\footnotetext{
${ }^{33}$ D. Walter, How the Alt-Right Invaded Geek Culture, “The Independent” 12.08.2016, http://www.independent.co.uk/voices/how-the-alt-right-invaded-geek-culture-a7214906.html [dostęp: 20.09.2017].

${ }^{34}$ J. Wilson, Gab. Alt-Right's Social Media Alternative Attracts Users Banned from Twitter, "The Guardian” 17.11.2016, https://www.theguardian.com/media/2016/nov/17/gab-alt-right-social-media-twitter [dostęp: 10.12.2017].

${ }^{35}$ D. Ng, Breitbart News Promts More Advertisers, "Los Angeles Times” 7.12.2016, http://www.latimes.com/business/hollywood/la-fi-ct-breitbart-bmw-deutsche-telekom-20161207story.html [dostęp: 10.12.2017].

${ }^{36}$ Również w badaniach prowadzonych przez amerykańskich badaczy dominuje postrzeganie Breitbart News jako medium alternatywnego, odmiennego od „tradycyjnego profesjonalnego dziennikarstwa”. Por. Y. Benkler, R. Faris, H. Roberts, E. Zuckerman, Breitbart-led right-wing media ecosystem altered broader media agenda, "Columbia Journalism Review" 3.03.2017, (https://www.cjr.org/analysis/breitbart-mediatrump-harvard-study.php, [dostęp: 04.03.2017]).

${ }^{37}$ P.J. Buchanan, A Republic, Not an Empire. Reclaiming America's Destiny, Washington 2002, s. 371.

${ }^{38}$ Tenże, Where the Right Went Wrong; New York 2004, s. 257-258.
} 


\section{PUBLIC RELATIONS W INSTYTUCJACH NON-PROFIT}

obecne w amerykańskim dyskursie imigracyjnym co najmniej od połowy XIX wieku, m.in. za sprawą prasy natywistycznej. Z kolei, rosnąca popularność teorii rasistowskich i eugeniki w pierwszych dwóch dekadach XX wieku doprowadziła do przejęcia tych elementów przez prasę prestiżową. W konsekwencji, w latach 1921-1924 przyjęto rozwiązania prawne opierające się na systemie kwot narodowościowych, które zahamowały masową imigrację.

O ile obecnie bezpośrednie odniesienia do rasizmu czy nacjonalizmu pojawiają się w dyskursie alternatywnej prawicy rzadko, to komentarze jej sympatyków w kwestii imigracji i imigrantów można zaliczyć do tzw. rasizmu ukrytego (covert racism). Jak wskazuje Ali Rattansi w swoim Racism. A Very Short Introduction, dyskwalifikacja rasizmu i eugeniki jako teorii całkowicie niezgodnych z nauką sprawiła, że językowa niechęć wobec „innego” wyrażana jest głównie poprzez odniesienia do odmiennej narodowości, kultury czy zwyczajów ${ }^{39}$. Zdaniem Chestera Pierce’a, „ukryte, wynikające z uprzedzenia rasowego decyzje są często ukrywane lub racjonalizowane przez wyjaśnienia, które społeczeństwo jest w stanie zaakceptować" ${ }^{40}$. W przeciwieństwie więc do tradycyjnego rasizmu, otwarcie wyrażanego przez uczestników dyskursu, ukryty rasizm jest trudny do udowodnienia, gdyż odwołuje się do norm, przynależności czy tożsamości danej społeczności. Jako taki, „ukryty rasizm jest często tłumaczony lub mylony z mechanizmami ekskluzji i inkluzji, rytuału i ceremonii, akceptacji i odrzucenia. Ukryty rasizm funkcjonuje jako granica utrzymująca mechanizm, którego głównym celem jest zachowanie społecznego dystansu pomiędzy rasową większością a mniejszościami” ${ }^{* 1}$. Zdając sobie sprawę, że głoszenie otwarcie rasistowskich haseł wykluczyłoby alternatywną prawicę z udziału w debacie publicznej, jej zwolennicy opanowali język metafor i aluzji $\mathrm{w}$ stopniu umożliwiającym im funkcjonowanie w popularnych mediach społecznościowych. Jak już wspomniano, czynią to przede wszystkim poprzez trzy gatunki medialne tożsame dla nowych ruchów społecznych, tj. zagłuszanie kultury, dziennikarstwo obywatelskie oparte na uczestnictwie oraz mobilizację przez media.

\section{Zagłtuszanie kultury}

Według cytowanej wcześniej Lievrouw, zagłuszanie kultury „polega na podchwytywaniu oraz przeinaczaniu obrazów i koncepcji obecnych w mediach głównego nurtu w celu przedstawienia krytycznego komentarza na ich temat" ${ }^{42}$. Innymi słowy, posługujący się tym gatunkiem wykorzystują, przekształcają, a często wręcz zawłaszczają obecne w kulturze masowej symbole, znaki czy technologie w celu krytyki tej kultury. Ważnym aspektem zagłuszania kultury są ironia i żart, które są ,skutecznymi metodami podejmowania dyskusji na temat problemów społecznych, politycznych czy gospodar-

\footnotetext{
${ }^{39}$ A. Rattansi, Racism. A Very Short Introduction, Oxford 2007, s. 87-89.

${ }^{40}$ Ch. Pierce, Offensive Mechanism, w: The Black Seventies, F.B. Barbour (red.), Boston 1970, s. 267.

${ }^{41}$ Introduction, w: Covert Racism. Theories, Institutions, and Experiences, R.D. Coates (red.), Leiden-Boston 2011, s. 2.

${ }^{42}$ L.A. Lievrouw, Media alternatywne..., dz. cyt., s. 94 .
} 

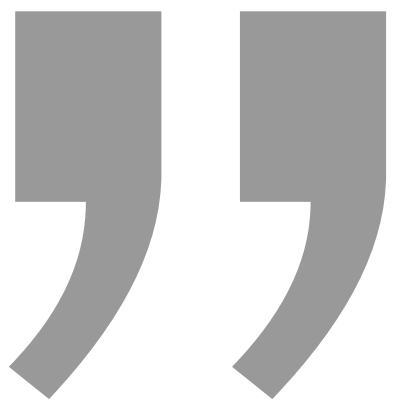

Korzystając z popularnych mediów społecznościowych, zwolennicy alternatywnej prawicy posługują się specjalnym językiem metafor i aluzji, dzięki któremu unikają oskarżeń o rasizm czy antysemityzm. Natomiast bezpośrednim językiem posługująą się we własnych mediach, takich jak Gab, stworzony jako nacjonalistyczna alternatywa dla Twittera.

czych (a nawet obrony idei kojarzonych z nimi), zdobywania zwolenników i zachęcania ich do działania" ${ }^{* 3}$. Przykłady takiego działania można odnaleźć w całej historii ruchów alternatywnych, począwszy od parodii reklam i marek odzieżowych, na tworzeniu fałszywej korporacji skończywszy. Współcześnie zagłuszanie kultury odbywa się m.in. przy wykorzystaniu memów internetowych, zwłaszcza, że stały się one jedną z najważniejszych i najpowszechniejszych jednostek kulturowych, tworzących i upowszechniających idee, symbole i praktyki.

W przypadku alternatywnej prawicy jednym z głównych sposobów zagłuszania kultury jest zawłaszczenie i przekształcenie znanego memu internetowego przedstawiającego żabę Pepe. Postać „Pepe the Frog” stworzył w 2005 roku amerykański artysta Matt Furie, który potrzebował bohatera do swojego niszowego komiksu pt. Boy's Club, opisującego życie współczesnego pokolenia dwudziestolatków ${ }^{44}$. Na przestrzeni kolejnych 11 lat Pepe stał się postacią kultową, zwłaszcza wśród nastolatków. Temu sukcesowi sprzyjało wykorzystywanie tego motywu przez popularne wśród młodego pokolenia gwiazdy muzyki i filmu, takie jak Katy Perry i Nicki Minaj ${ }^{45}$. Niektóre z postów z Pepe the Frog, publikowanych na Instagramie, zdobywały sympatię niemal 300 tys. osób. Proces zawłaszczania postaci przez alternatywną prawicę rozpoczął się w 2015 roku, kiedy to coraz częściej Pepe the Frog był prezentowany z symbolami nazistowskimi i nacjonalistycznymi. Wkrótce też memy z jego udziałem zaczęli powszechnie stosować zwolennicy Donalda Trumpa, wówczas jeszcze jednego z kandydatów w prawyborach prezydenc-

\footnotetext{
${ }^{43}$ Tamże, s. 109.

${ }^{44}$ A. Serwer, It's Not Easy Being Meme, "The Atlantic” 13.09.2016, online:

http://www.theatlantic.com/politics/archive/2016/09/its-not-easy-being-green/499892/ [dostęp: 13.12.2017].

${ }^{45}$ O. Nuzzi, How Pepe the Frog Became a Nazi Trump Supporter and Alt-Right Symbol, "The Daily Beast” 25.05.2016, online: http://www.thedailybeast.com/articles/2016/05/26/how-pepe-the-frog-became-a-nazitrump-supporter-and-alt-right-symbol.html [dostęp:13.12.2017].
} 
kich organizowanych przez Partię Republikańską. Sam Trump użył memu stylizowanego na niego samego ${ }^{46}$. Skala zawłaszczenia memu przez alternatywną prawicę była tak duża, że w 2016 roku The Anti-Defamation League zaliczyła Pepe the Frog do symboli nienawiści, łącznie ze swastyką czy symbolami Ku Klux Klanu ${ }^{47}$.

Do głównych memów z udziałem Pepe the Frog, rozpowszechnianych przez zwolenników alternatywnej prawicy, należą te skierowane przeciwko imigracji i mniejszościom etnicznym. Trudno określić ich dokładną liczbę - podobnie, jak w przypadku innych tego typu tworów, także popularność tego zależy jedynie od wyobraźni internautów. Wśród najczęściej występujących można znaleźć memy prezentujące Pepe stylizowanego na Donalda Trumpa przyglądającego się pozostającej za płotem granicznym meksykańskiej rodzinie, przedstawionej w sposób stereotypowy (mężczyzna jest ubrany w sombrero i ponczo, ma wielkie wąsy). W innym, uśmiechnięty szyderczo i ubrany w hidżab Pepe stoi obok zwłok białej osoby. Istnieje ponadto cała seria memów z Pepe stylizowanym na przedstawicieli różnych nacji - Pepe Żyd, Pepe Arab, Pepe Meksykanin, Pepe Chińczyk. Wszystkie je łączy stereotypowe ukazanie mniejszości - Pepe Żyd ma długi nos, Pepe Meksykanin sumiaste wąsy itp. Towarzyszą im negatywne, choć utrzymane w satyrycznym tonie komentarze. Na przykład pod wizerunkiem Pepe Chińczyka znajduje się napis: „Polub ten mem, albo on zje cały twój ryż”. Jeszcze inne odwołują się do tzw. zdrowego rozsądku. Pepe zadaje pytania dotyczące polityki imigracyjnej, stosunku do muzułmanów czy też poprawności politycznej, a odpowiedź stanowią zamieszczone obok niego zdjęcia, np. samobójczych zamachów, nielegalnych imigrantów czy uzbrojonych islamskich terrorystów.

Powyższe memy rozpowszechniają w internecie nie tylko zwolennicy alternatywnej prawicy. Często robią to nieświadomie inni użytkownicy, w tym nastoletni internauci, którzy nie zauważają antysemickiego czy nacjonalistycznego wydźwięku danego memu. Dla wielu z nich Pepe ustylizowany na Adolfa Hitlera czy żołnierza SS nie niesie za sobą treści ideologicznych, lecz jest jedynie „śmieszny”. Co więcej, część użytkowników postrzega rozpowszechnianie tego rodzaju memów jako sprzeciw wobec „poprawności politycznej”, którą utożsamiają z cenzurą. Jak zauważa w swoim raporcie The AntiDefamation League, „sam fakt zamieszczania memów z Pepe nie oznacza, że ktoś jest rasistą lub zwolennikiem supremacji białych" ${ }^{48}$. Jednak dla zwolenników alternatywnej prawicy przekaz, który niesie Pepe the Frog, jest jednoznaczny. Stał się on nie tylko symbolem ich ruchu, ale także sposobem funkcjonowania w świecie politycznej poprawności, gdzie bezpośrednie nawiązania do rasizmu czy antysemityzmu są wykluczone. Prze-

\footnotetext{
${ }^{46}$ M. Conway, "Pepe the Frog" Creator, Blaming the Election, Tries to Reclaim His Cartoon, "Politico" 13.10.2016, http://www.politico.com/story/2016/10/pepe-the-frog-matt-furie-reclaim-cartoon-229757 [dostęp: 14.11.2017].

${ }^{47}$ L. Westcott, Pepe the Frog Joins Swastika, Burning Cross as Hate Symbol, "Newsweek" 30.09.2016, http://europe.newsweek.com/pepe-frog-hate-symbol-alt-right-503773?rm=eu [dostęp:10.12.2017].

${ }^{48}$ P. Young, Alt-Right Meme Pepe the Frog Branded Hate Symbol by ADL, "Long Island Wins" 06.10.2016, https://longislandwins.com/news/national/alt-right-meme-pepe-frog-branded-hate-symbol-adl/ [dostęp:10.12.2017].
} 

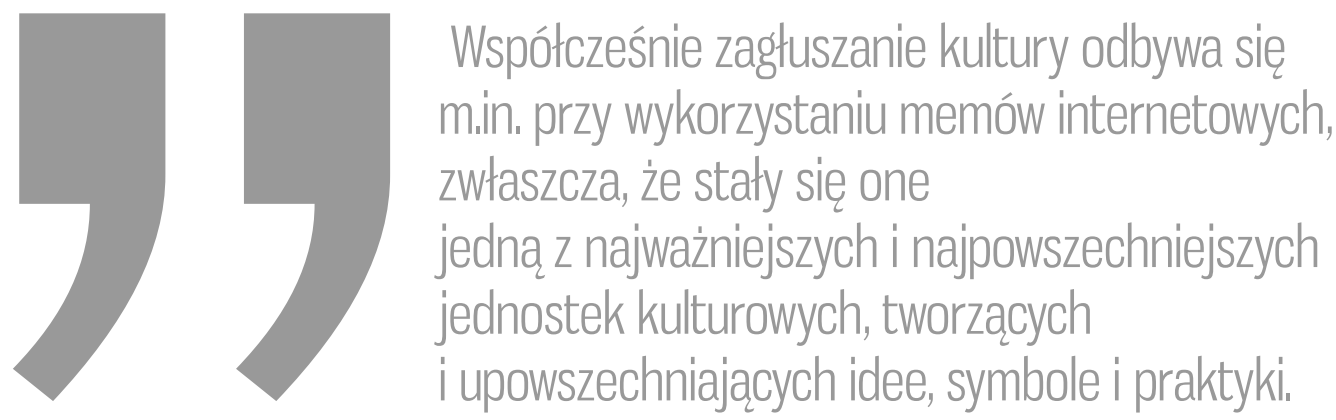

chwytując jeden z najpopularniejszych wytworów kultury masowej, alternatywna prawica doprowadziła do radykalizacji dyskursu, m.in. w kwestii imigracji.

\section{Dziennikarstwo obywatelskie}

Definicje dziennikarstwa obywatelskiego są często tożsame z definicjami mediów alternatywnych. Część badaczy zalicza każdy rodzaj medialnej aktywności obywatelskiej do rodzaju mediów alternatywnych. Podkreślają oni ich amatorski, niezależny charakter, dodając, że ,z jednej strony podtrzymują one tradycyjne wartości oraz praktyki dziennikarstwa czy prasy, a z drugiej wchodzą z nimi w krytyczny dialog"49. Ponadto, dziennikarstwo obywatelskie często podejmuje tematy przemilczane - z różnych powodów przez profesjonalne media. Jednakże, automatyczne uznanie wszystkich form obywatelskiego dziennikarstwa za media alternatywne byłoby nadużyciem. Wiele z amatorskich projektów funkcjonujących w internecie powiela bowiem informacje pozyskane z tradycyjnych mediów. Inne zostają przejęte przez medialne korporacje i tracą swoją niezależność, tak jak to było w przypadku „The Huffington Post” ${ }^{\text {50 }}$. Jeszcze inne jedynie imitują niezależne, amatorskie projekty, faktycznie zaś są finansowane przez potężne przedsiębiorstwa lub grupy interesu.

Podobnych pytań nastręczają projekty medialne związane z ruchem amerykańskiej alternatywnej prawicy. Jak już wspomniano, początków jej wzmożonej internetowej aktywności można doszukiwać się w pierwszych latach XXI w., kiedy to powstało wiele różnego rodzaju stron internetowych, grup dyskusyjnych czy forów, zrzeszających sympatyków „alt-right”. Internet służył im głównie do rozpowszechniania informacji, mobilizacji zwolenników i prezentowania kandydatów do stanowisk politycznych ${ }^{51}$. Przełom nastąpił w roku 2002 wraz z powstaniem strony www.usteaparty.com, która zapoczątkowała proces konsolidacji obecności alternatywnej prawicy w internecie. Jak wy-

\footnotetext{
${ }^{49}$ L.A. Lievrouw, Media alternatywne..., dz. cyt., s. 154.

${ }^{50}$ Por. K. Wasilewski, „The Huffington Post” I “OhmyNews”- analiza porównawcza dwóch globalnych dzienników internetowych, w: A. Jaskiernia, K. Gajlewicz-Korab, Rozwój internetu a zmiany w mediach, systemach medialnych oraz społecznych, Warszawa 2016, s. 347-359.

${ }^{51}$ M. Caiani, L. Parenti, European and American Extreme Right Groups and the Internet, London and New York 2013, s. 108-109.
} 
kazała kampania prezydencka z 2016 roku, ważną pozycję na rynku zajmuje Breitbart News Network (www.breitbart.com), założona w 2007 roku przez konserwatywnego publicystę i przedsiębiorcę Andrew Breitbarta. Po jego śmierci w 2012 roku stroną zaczął zarząazać Stephen Bannon, który nadał jej jeszcze bardziej radykalny charakter ${ }^{52}$. W przeciwieństwie do wielu wcześniejszych projektów, Breitbart News Network prowadzony jest profesjonalnie, zatrudnia dziennikarzy, a nawet korespondentów zagranicznych $^{53}$. Ponadto, jednym z celów funkcjonowania serwisu jest także zysk, stąd obecność na jego łamach reklam. Samo finansowanie Breitbart News, jak również pozostałych tego typu projektów, budzi zastrzeżenia, gdyż za pośrednictwem osób prywatnych de facto wsparcia często udzielają im potężne przedsiębiorstwa. W przypadku niektórych, jak na przykład The Patriot News Agency „stworzonej przez patriotów dla patriotów”, okazało się wręcz, że są to projekty prowadzone i finansowane przez obcokrajowców ${ }^{54}$.

Mimo powyższych wątpliwości faktem jest rosnąca pozycja internetowych serwisów związanych z alternatywną prawicą. Według „Alexa” - witryny mierzącej ruch generowany na stronach internetowych - w listopadzie 2016 roku Breitbart.com plasowal się pod względem liczby unikatowych odwiedzin na 42 pozycji w Stanach Zjednoczonych i 251 na świecie ${ }^{55}$. Dla porównania, w tym samym okresie witryna „The New York Times” zajęła 28 miejsce, a CNN - miejsce 22. Oznacza to, że dysponując o wiele mniejszymi funduszami i rozpoznawalnością, Breitbart.com stał się jednym z ważniejszych źródeł informacji, nie tylko dla zadeklarowanych sympatyków alternatywnej prawicy. Szczyt popularności Breitbart News przypadł na ostatnie tygodnie kampanii prezydenckiej w Stanach Zjednoczonych. Jak wskazuje Google Trends, w tym samym okresie apogeum popularności osiągnęło także zapytanie na temat imigracji ${ }^{56}$. Trudno się temu dziwić, zważywszy, że imigracja stanowiła jeden z najważniejszych problemów dyskutowanych podczas tej kampanii.

Podczas, gdy większość mediów głównego nurtu stara się wskazywać na złożoność tego problemu, podkreślając zarazem humanitarny wymiar polityki imigracyjnej, Breitbart News wraz z pozostałymi witrynami sympatyzującymi z alternatywną prawicą przyjmuje jednoznacznie negatywne stanowisko. Wśród cech charakterystycznych dyskursu imigracyjnego prowadzonego na łamach Breitbart.com, do najważniejszych można zaliczyć przedstawianie imigrantów jako jednolitej masy, koncentrację na negatyw-

\footnotetext{
${ }^{52}$ D. Victor, L. Stack, Stephen Bannon and Breitbart News, in Their Words, "The New York Times" 14.11.2016, (http://www.nytimes.com/2016/11/15/us/politics/stephen-bannon-breitbart-words.html?_r=0 [dostęp:10.12.2017].

${ }^{53}$ J.E. Bromwich, What Is Breitbart News?, “The New York Times” 17.08.2016, http://www.nytimes.com/2016/08/18/business/media/what-is-breitbart-news.html [dostęp: 10.12.2017].

${ }^{54}$ M. McIntire, How a Putin Fan Overseas Pushed Pro-Trump Propaganda to Americans, "The New York Times” 17.12.2016, http://www.nytimes.com/2016/12/17/world/europe/russia-propagandaelections.html?smid=fb-nytimes\&smtyp=cur\&_r=0 [dostęp: 17.12.2017].

${ }^{55}$ Por. http://www.alexa.com/siteinfo/breitbart.com, 16.12.2017.

${ }^{56}$ Por. https://www.google.pl/trends/explore?date=today\%2012-m\&geo=US\&q=immigration [dostęp: 16.10.2017]
} 

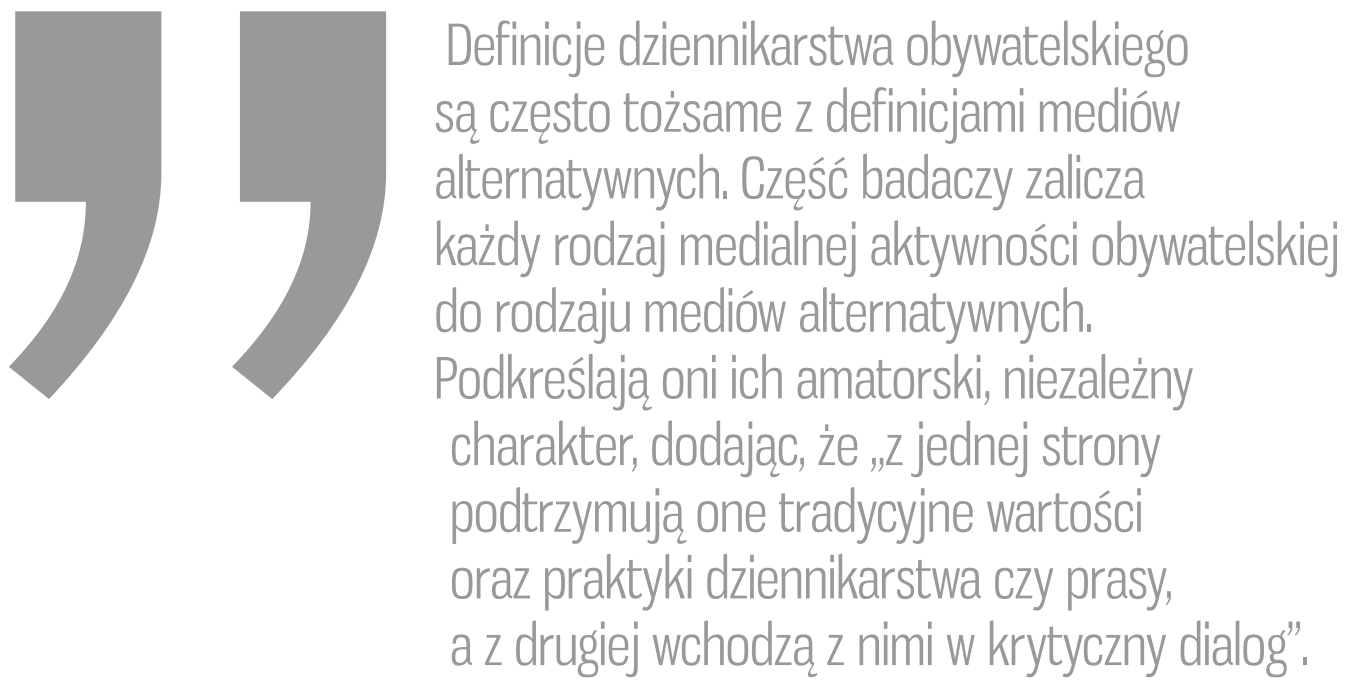

nym aspekcie imigracji oraz powielanie niesprawdzonych, a często wręcz fałszywych informacji. Taki sposób obrazowania imigracji i imigrantów nie jest bynajmniej ograniczony tylko do mediów radykalnej prawicy, lecz funkcjonuje również w niektórych mediach głównego nurtu, jak np. w prasie tabloidowej ${ }^{57}$.

Zwolennicy utrzymania obecnych przepisów imigracyjnych czy tė̇ abolicji dla nielegalnych imigrantów są przedstawiani jako działający na szkodę interesu Stanów Zjednoczonych i całego społeczeństwa. Na przykład dziennikarz Breitbart News powiązał działalność kalifornijskiego oddziału „Amnesty International” przeciwko deportacjom imigrantów z rosnącą przestępczością, podkreślając między innymi, że aktywiści stowarzyszenia chcą ukryć przed władzami federalnymi listy z nazwiskami członków lokalnych gangów ${ }^{58}$. Zdaniem portalu wszelkie doniesienia o pozytywnych aspektach imigracji były jedynie „ideologicznymi mrzonkami mediów głównego nurtu”. Podobnie, osoby opowiadające się przeciwko drastycznemu zaostrzeniu polityki imigracyjnej miały reprezentować bliżej nieokreślone grupy interesów. W trakcie kampanii wyborczej witryna wielokrotnie publikowała sondaże opinii publicznej wskazujące, że większość amerykańskiego społeczeństwa opowiadała się za zaostrzeniem polityki imigracyjnej. Jak przekonywano, takie stanowisko Amerykanów nie mogło dziwić zważywszy, że masowa imigracja była głównym powodem wzrostu bezrobocia, obniżenia płac i „wyparowania amerykańskiego snu" ${ }^{59}$. Ważnym elementem dyskursu imigracyjnego były odpowiednio sformatowane ilustracje, przedstawiające przemiennie imigrantów-przestępców i ubogich amerykańskich obywateli - ofiary wzmożonej imigracji.

\footnotetext{
${ }^{57}$ Por. R. Benson, Shaping Immigration News. A French-American Comparison, New York 2013, s. 4-9.

${ }^{58}$ A. Hawkins, Amnesty Groups Fight to Hide California Gang Database from Trump, "Breitbart News" 06.12.2016, (http://www.breitbart.com/california/2016/12/06/immigrant-groups-want-hide-californiagang-database-trump/ [dostęp: 16.12.2017].

${ }^{59}$ N. Munro, American Dream Evaporates, „Breitbart News” 08.12.2016, (http://www.breitbart.com/biggovernment/2016/12/08/american-dream-sliding-irs-data/ [dostęp: 16.12.2017].
} 
Specyficzny sposób opisywania imigracji przez Breitbart News wpłynął na kształt całego dyskursu imigracyjnego w okresie kampanii prezydenckiej. Po pierwsze, terminy „,imigracja” i „,nielegalna imigracja” zostały ze sobą utożsamione. Chociaż większość publikowanych tekstów dotyczyła obcokrajowców przebywających w USA niezgodnie z prawem, przymiotnik „nielegalny” był stosowany rzadko. Po drugie, materiały dotyczące imigrantów skupiały się głównie na dwóch grupach - Latynosach i muzułmanach. Ta pierwsza grupa stała się synonimem nielegalnego imigranta, przestępcy lub obniżającego standardy płacowe robotnika. Z kolei muzułmanie zostali przedstawieni jako fanatycy religijni, odpowiedzialni za wzrost zagrożenia terrorystycznego. Po trzecie, uprawomocniono pozostające dotychczas na marginesie publicznej debaty fobie związane z „niemożnością asymilacji” czy „różnicami kulturowymi” niektórych grup obcokrajowców.

\section{Mobilizacja przez media}

Jednym z podstawowych celów funkcjonowania mediów alternatywnych jest mobilizacja grup społecznych przeciwko politycznemu, społecznemu czy kulturowemu status quo. O ile tradycyjne media takie, jak prasa czy radio, mają ograniczony zasięg i oddziałują przede wszystkim na osoby już świadome swoich poglądów, o tyle nowe media, w tym zwłaszcza internet, pozwalają uniknąc zagrożenia powstania „,alternatywnego getta"60. Jak trafnie zauważyła Lievrouw, „mobilizacja przez media idzie jednak krok dalej i wykorzystuje nowe media jako narzędzia służące do mobilizowania ruchów społecznych. Polega ona na zbiorowym działaniu, w ramach którego ludzie organizują się i działają razem, będąc aktywnymi uczestnikami zmian społecznych" ${ }^{\circ 1}$. Badaczka podkreśla także, że wielkie, zorganizowane kampanie polityczne skierowane do całego społeczeństwa ustępują obecnie organizowanym ad hoc wydarzeniom odwołującym się do potrzeb określonej grupy społecznej. Może to być protest przeciwko uchwalonej właśnie ustawie lub pojedyncza akcja krytykująca kontrowersyjną wypowiedź lub zachowanie danego polityka. Możliwości oferowane przez nowe media doskonale wykorzystuje amerykańska alternatywna prawica. Ruch Tea Party połączył osoby o różnych poglądach i pozycji społecznej, zebrane początkowo chęcią zmiany najpierw w łonie Partii Republikańskiej, a następnie w całym kraju. Tea Party nie miała zorganizowanych struktur, władz czy nawet oficjalnych członków, a swoje funkcjonowanie opierała niemal wyłącznie na nowych mediach ${ }^{62}$. Stały się one również podstawą kampanii wyborczych wielu polityków związanych z Tea Party, a następnie z ,alt-right”, na czele z Donaldem Trumpem ${ }^{63}$.

\footnotetext{
${ }^{60}$ S. Elghul-Bebawi, The Relationship Between Mainstream and Alternative Media. A Blurring of the Edges?, w: Notions of Community. A Collection of Community Media, J. Gordon (red.), Berlin 2011, s. 22.

${ }^{61}$ L.A. Lievrouw, Media alternatywne..., dz. cyt., s. 190.

${ }^{62}$ D. Karpf, The MoveOn Effect. The Unexpected Transformation of American Political Advocacy, New York 2012, s. 135-138.

${ }^{63}$ K. Lockhart, Why Social Media is Donald Trump's most powerful weapon, “The Telegraph” 22.09.2016, (http://www.telegraph.co.uk/news/2016/09/22/watch-why-social-media-is-donald-trumps-most-powerfulweapon/, 10.12.2017).
} 
K. Wasilewski, Internetowa aktywność amerykańskiego ruchu alternatywnej prawicy... 

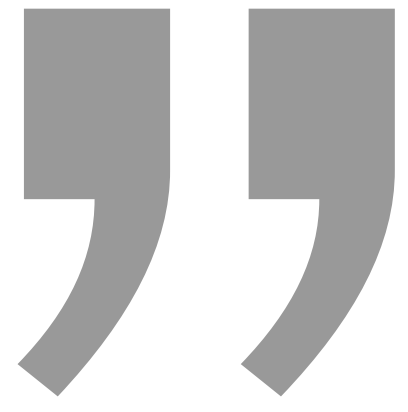

Media alternatywnej prawicy odegrały istotną rolę w mobilizacji jej sympatyków przeciwko imigrantom i imigracji. W czasie ostatniej kampanii prezydenckiej liczne strony internetowe i fora służyły m.in. do angażowania użytkowników - zarówno w sieci, jak i w świecie realnym - do wyrażenia swojego niezadowolenia z dotychczasowej polityki imigracyjnej rządu federalnego. W pierwszym przypadku agresywna publicystyka witryn internetowych związanych z alternatywną prawicą uaktywniała użytkowników do wyrażenia swojej opiniil w mediach społecznościowych.

Media alternatywnej prawicy odegrały istotną rolę w mobilizacji jej sympatyków przeciwko imigrantom i imigracji. W czasie ostatniej kampanii prezydenckiej liczne strony internetowe i fora służyły m.in. do angażowania użytkowników - zarówno w sieci, jak i w świecie realnym - do wyrażenia swojego niezadowolenia z dotychczasowej polityki imigracyjnej rządu federalnego. W pierwszym przypadku agresywna publicystyka witryn internetowych związanych $\mathrm{z}$ alternatywną prawicą uaktywniała użytkowników do wyrażenia swojej opinii w mediach społecznościowych. Przez cały rok 2016 Facebook czy Twitter doświadczały zmasowanych kampanii sympatyków ,alt-right” wypowiadających się przeciwko imigracji i imigrantom $^{64}$. Jak wskazuje publicystka Amelia Tait, poglądy wyrażane w internecie znajdowały bezpośrednie odniesienie w programach wyborczych: „Zamiast polegać na publicznych spotkaniach, kandydaci mogą dowiedzieć się o opiniach wyborców - i odpowiednio dostosować swój program - w czasie rzeczywistym”" ${ }^{65}$. Jednocześnie - jak już wspomniano - zwolennicy alternatywnej prawicy potrafili wypracować specjalny język metafor i symboli, dzięki któremu ich radykalne poglądy mogły zaistnieć w ogólnodostępnych serwisach.

Media alternatywnej prawicy mobilizowały zarazem swoich sympatyków do akcji realizowanych w „świecie realnym”. Można było to zaobserwować podczas kam-

\footnotetext{
${ }^{64}$ A. Tait, Control, Alt-Right, Retweet: How Social Media Paved the Way for President Trump, "The New Statesman" 10.11.2016, (http://www.newstatesman.com/world/north-america/2016/11/control-alt-rightretweet-how-social-media-paved-way-president-trump [dostęp: 11.12.2017].

${ }^{65}$ Tamże.
} 
panii prezydenckiej Donalda Trumpa, kiedy to często jednego dnia spotykał się on z mieszkańcami kilku miejscowości, znajdujących się nierzadko w różnych stanach. Tradycyjne sposoby komunikacji, jak prasa czy działalność przedstawicieli wyborczych, nie byłyby w stanie sprostać takiemu wyzwaniu. Ponadto, $w$ trakcie takich wieców zwolennicy Trumpa deklarowali swój sprzeciw wobec dotychczasowej polityki imigracyjnej rządu federalnego; sprzeciw, którego podstawą były informacje i opinie publikowane przez Breitbart News i pozostałe tytuły związane z alternatywną prawica. Jak wykazały badania opinii publicznej przeprowadzone w sierpniu 2016 r. przez Pew Research Center, dla 66 proc. osób deklarujących poparcie dla Donalda Trumpa kwestia imigracji stanowiła priorytet, ważniejszy nawet od terroryzmu. Dla porównania, zaledwie 17 proc. zwolenników Hillary Clinton było podobnego zdania ${ }^{66}$. Co więcej, w tej pierwszej grupie niemal 80 proc. badanych za najskuteczniejszy sposób walki z nielegalną imigracją uważało budowę muru na granicy z Meksykiem ${ }^{67}$. Nie przez przypadek mur graniczny stał się słowem-kluczem w całej antyimigranckiej kampanii prowadzonej przez media alternatywnej prawicy.

\section{Podsumowanie}

Wraz ze zwycięstwem Donalda Trumpa w wyborach prezydenckich w 2016 r., ruch alternatywnej prawicy zyskał powszechne zainteresowanie mediów - amerykańskich i zagranicznych. Warto jednak podkreślić, że nie powstał on w próżni, lecz jako nowy ruch społeczny budował swoją pozycję w globalnej sieci już od początku XXI wieku. W międzyczasie liczne blogi, fora i grupy dyskusyjne, zakładane przez amatorów, zostały uzupełnione w branży o profesjonalne serwisy informacyjne i publicystyczne, takie jak na przykład Breitbart News. Wszystkie one umożliwiły zwolennikom alternatywnej prawicy aktywne kwestionowanie politycznego, społecznego i kulturowego status quo wStanach Zjednoczonych.

Podobnie, jak w przypadku każdego nowego ruchu społecznego, w szeregach alternatywnej prawicy znajdują się osoby o różnym wykształceniu, statusie społecznym, a nawet światopoglądzie. Jednym z głównych elementów łączących wszystkich sympatyków „alt-right” jest natomiast krytyka obecnej polityki imigracyjnej USA i niechęć wobec imigrantów w ogóle. Dążąc do zmiany akcentów w debacie publicznej na temat imigracji, zwolennicy alternatywnej prawicy posługują się różnymi gatunkami medialnymi, w tym przede wszystkim - przybliżonymi powyżej - zagłuszaniem kultury, dziennikarstwem obywatelskim oraz mobilizacją przez nowe media. Pozostałe, a więc hackerstwo i wspólne zasoby wiedzy, w przypadku debaty imigracyjnej odgrywają poślednią rolę, choć - co należy podkreślić - są sympatykom „alt-right" dobrze znane. Upublicznienie korespondencji Narodowego Komitetu Partii Demokratycznej, czy wykorzystanie WikiLeaks w celu dyskredytacji przeciwników po-

\footnotetext{
${ }^{66}$ J. Boccagno, Immigration Remains Top Concern for Trump Supporters, “CBS News”, 26.08.2016, http://www.cbsnews.com/news/poll-immigration-donald-trump-supporters/ [dostęp: 14.12.2017]. ${ }^{67}$ Tamże.
} 


\section{PUBLIC RELATIONS W INSTYTUCJACH NON-PROFIT}

litycznych, to tylko dwa z wielu potwierdzających to przykładów ${ }^{68}$. Tymczasem przejmując i przekształcając produkty kultury masowej, bądź też wprowadzając do mediów społecznościowych fałszywe informacje, zwolennicy amerykańskiej alternatywnej prawicy stopniowo radykalizują debatę publiczną na temat imigracji. Tworzenie popularnych memów propagujących nacjonalistyczne i rasistowskie hasła czy zawłaszczenie serwisów społecznościowych umożliwiło włączenie do publicznego obiegu poglądów skrajnych i do tej pory marginalizowanych. Za zasadną można tym samym uznać tezę postawioną na początku niniejszego artykułu, że media alternatywnej prawicy, wykorzystując możliwości oferowane im m.in. przez internet, doprowadziły do radykalizacji dyskursu imigracyjnego w USA.

\section{BIBLIOGRAFIA}

Allmer T., Critical Theory and Social Media. Between emancipation and commodification, London and New York 2015.

Atton Ch., Alternative Media, London-Thousand Oaks-New Delhi 2003.

Benkler Y., Faris R., Roberts H., Zuckerman E., Breitbart-led right-wing media ecosystem altered broader media agenda, "Columbia Journalism Review" 3.03.2017, https://www.cjr.org/analysis/breitbart-media-trump-harvard-study.php [dostęp: 04.12.2017].

Benson B., Shaping Immigration News. A French-American Comparison, New York 2013.

Bokhari A., M. Yiannopoulos, An Establishment Conservative's Guide to the Alt-Right, 29.03.2016, http://www.breitbart.com/tech/2016/03/29/an-establishment-conservatives-guide-to-the-alt-right [dostęp: 08.09.2017 r.].

Buchanan P.J., A Republic, Not an Empire. Reclaiming America's Destiny, Washington 2002.

Buchanan P.J., Where the Right Went Wrong, New York 2004.

Caiani M., Parenti L., European and American Extreme Right Groups and the Internet, London and New York 2013.

Ch. Meyer, A New American Revolution? Anti-establishment Tea Party is on the brink of election victories that could leave Obama a lame duck, "Mail Online", 25.10.2010, http://www.dailymail.co.uk/news/article1323047/Anti-establishment-Tea-Party-leave-Obama-lame-duck.html [dostęp: 07.12.2017 r.].

Cillizza Ch., How Immigration Could Cripple the Republican Nominee Long Before the 2016 Election, "The Washington Post" 17.07.2015, https://www.washingtonpost.com/news/the-fix/wp/2015/06/17/how-immigration-could-cripple-the-republican-nominee-long-before-

\footnotetext{
${ }^{68}$ Por. R. Dimanno, Julian Assange now the hero of the alt-right, "The Toronto Star" 15.11.2016, https://www.thestar.com/news/gta/2016/11/15/julian-assange-now-the-hero-of-the-alt-rightdimanno.html [dostęp: 12.12 .2017 r.].
} 
-the-2016-general-election/?utm_term=.4c34f3c1d6e7 [dostęp: 10.11.2017 r.].

Comedia, The Alternative Press. The Development of Underdevelopment, "Media, Culture and Society" 1984, vol. 6, s. 95-102.

Couldry N., Beyond the Hall of Mirrors? Some Theoretical Reflections on the Global Contestation of Media Power. W: Contesting Media Power. Alternative Media in a Networked World, N. Couldry, J. Curran (red.), London 2003.

Culture Wars in America. An Encyclopedia of Issues, Viewpoints, and Voices, vol. 1-3, R. Chapman, J. Ciment (red.), London and New York 2014.

Dagron A.G., The Long and Winding Road of Alternative Media, w: The SAGE Handbook of Media Studies, J.H. Downing (red.), London 2004.

Downing J.H., Radical Media. Rebellious Communication and Social Movements, London 2001.

Duarte J., Futures \& Options, Hoboken 2006.

Fairclough N., Analyzing Discourse. Textual Analysis for Social Research, London 2003.

Fiske J., British Cultural Studies and Television. W: Channels of Discourse. Reassembled, R.C. Allen (red.), London 1992.

Golka B., System medialny Stanów Zjednoczonych, Warszawa 2004.

Herman E.S., Chomsky N., Manufacturing Consent, London 1989.

Introduction, w: Covert Racism. Theories, Institutions, and Experiences, R.D. Coates (red.), Leiden-Boston 2011.

Karpf D., The MoveOn Effect. The Unexpected Transformation of American Political Advocacy, New York 2012.

Kirk R., The Conservative Mind. From Burke to Eliot, Washington 2001.

Lievrouw L.A., Media alternatywne i zaangażowanie społeczne, Warszawa 2012.

Marcuse H., An Essay on Liberation, Boston 1969.

Morowitz A., Trolls for Trump, „The New Yorker”, 31.10.2016, http://www.newyorker.com/magazine/2016/10/31/trolls-for-trump [dostęp: 10.11.2017 r.].

Parker Ch.S., Baretto M.A., Change They Can't Believe in. The Tea Party and Reactionary Politics in America, Princeton 2013.

Pierce Ch., Offensive Mechanism, w: The Black Seventies, F.B. Barbour (red.), Boston 1970.

Pisarek W. (red.), Słownik terminologii medialnej, Kraków 2006.

Press B., Train Wreck. The End of the Conservative Revolution, Hoboken 2008.

Rattansi A., Racism. A Very Short Introduction, Oxford 2007.

Viguerie R.A., Franke D., America's Right Turn, Chicago and Los Angeles 2004. 
Wasilewski K., „,The Huffington Post” I “OhmyNews” - analiza porównawcza dwóch globalnych dzienników internetowych, w: A. Jaskiernia, K. Gajlewicz-Korab, Rozwój internetu a zmiany w mediach, systemach medialnych oraz społecznych, Warszawa 2016, s. 347-359.

Williamson K.D., The Father Führer, "The National Review” 2016, vol. LXVIII, no. 5 .

\section{OAUTORZE:}

Krzysztof Wasilewski - dr nauk humanistycznych, historyk i medioznawca, pracownik naukowy Wojewódzkiej i Miejskiej Biblioteki Publicznej im. Zbigniewa Herberta w Gorzowie Wielkopolskim; zainteresowania badawcze: media alternatywne, framing, komunikowanie międzykulturowe, analiza dyskursów migracyjnych; KONTAKT: krzys.wasilewski@gmail.com. 
кuLTura- мeDia- TeoLogia

ISSN 2081-8971

$2017 \mathrm{nr} 30$, s. $122-135$.

\title{
Public relations w kształtowaniu wizerunku polskiego publicznego szkolnictwa na poziomie szkół średnich i gimnazjów
}

\author{
Public relations in shaping the image of polish, public education \\ at the level of primary and secondary schools
}

\begin{abstract}
STRESZCZENIE:
CELEM ARTYKUŁU JEST OMÓWIENIE PROBLEMATYKI ZWIĄZANEJ Z KREOWANIEM WIZERUNKU PRZEZ POLSKIE SZKOŁY PUBLICZNE. W SZCZEGÓLNOŚCI, ANALIZIE PODDANE ZOSTAEY TECHNIKI, NARZĘDZIA I KANAEY KOMUNIKACJI PROWADZONE PRZEZ TE JEDNOSTKI. PODSTAWOWE PYTANIE, KTÓRE PRZYŚWIECA PODJĘTYM TU ROZWAŻANIOM, ODNOSI SIĘ DO ZASADNOŚCI SAMEJ KOMUNIKACJI, SPOSOBÓW JEJ REALIZACJI I UŻYTYCH DO REALIZACJI TEGO CELU KANAEÓW KOMUNIKACYJNYCH.

CAŁOŚĆ ROZWAŻAŃ ZOSTAŁA OSADZONA W RAMACH TEORETYCZNYCH TZW. KRYTYCZNEJ ANALIZIE DYSKURSU I POPARTA ANALIZĄ PRZYTOCZONYCH PRZYKŁADÓW, TJ. KOMUNIKACJI BEZPOŚREDNIEJ W ŚWIECIE RZECZYWISTYM ADRESOWANEJ DO RODZICÓW, IMIENNEJ KOMUNIKACJI POŚREDNIEJ PRZY UŻYCIU LIBRUSA, KOMUNIKACJI POŚREDNIEJ PRZY UŻYCIU STRON INTERNETOWYCH PROWADZONYCH PRZEZ PLACÓWKI ORAZ INFORMACJE MEDIALNE O SZKole I JEJ DZIAEANIACH. CELEM BADANIA JEST USTALENIE POZIOMU PROWADZENIA I WYKORZYSTANIA ŚRODKÓW ORAZ NARZĘDZI, ZA POMOCĄ KTÓRYCH SZKOŁY PUBLICZNE NA TERENIE RP BUDUJĄ SWÓJ WIZERUNEK.
\end{abstract}

\section{SŁOWA KLUCZOWE:}

BUDOWANIE WIZERUNKU, KOMUNIKACJA, PUBLICZNE INSTYTUCJE OŚWIATOWE

\begin{abstract}
:
THIS ARTICLE AIMS TO DISCUSS ISSUES RELATED TO CREating THE IMAGE OF THE POLISH PUBliC SCHOOLS. THE ANALYSIS COVERED TECHNIQUES, TOOLS AND COMMUNICATION CHANNELS. THE BASIC QUESTION THAT GUIDED MEDITATIONS TAKEN HERE, REFERS TO THE VALIDITY OF THE SAME COMMUNICATION, WAYS OF IMPLEMENTATION AND USED FOR THAT PURPOSE COMMUNICATION CHANNELS. THE WHOLE DISCUSSION HAS BEEN SET IN THE FRAMEWORK OF THEORETICAL THE SOCALLED CRITICAL DISCOURSE ANALYSIS AND SUPPORTED BY AN ANALYSIS OF THE EXAMPLES, IT IS DIRECT REAL-WORLD COMMUNICATION ADDRESSED TO PARENTS REGISTERED INDIRECT COMMUNICATION WITH LIBRUS, INDIRECT COMMUNICATION VIA WEBSITES OPERATED BY INSTITUTIONS AND MEDIA INFORMATION ABOUT THE SCHOOL AND ITS ACTIVITIES. THE AIM OF THE STUDY IS TO DETERMINE THE MEASURES AND TOOLS AND THE MEANS BY WHICH PUBLIC SCHOOLS IN POLAND BUILD ITS IMAGE.
\end{abstract}

\section{KEYWORDS:}

PUBLIC RELATIONS, COMMUNICATION, PUBLIC EDUCATIONAL INSTITUTIONS 
zkolnictwo w Polsce jest powszechne i bezpłatne, a nauka obowiązkowa dla osób poniżej 18 roku życia ${ }^{1}$, zatem dostęp do placówek oświatowych nie stanowi problemu, jedynie w niewielkiej części szkół przyjęcie ucznia zależy od średniej jego ocen. Oczekiwanym wkładem ze strony ucznia są więc dobre wyniki w nauce. W dobie niżu demograficznego inną sytuację na rynku oświatowym mają szkoły, które dla utrzymania odpowiedniego poziomu nauczania oraz pozyskania odpowiedniej liczby uczniów, a co za tym idzie utrzymania zatrudnienia nauczycieli i utrzymania odpowiedniego statusu instytucji, muszą zabiegać o klienta - ucznia. Dotyczy to zarówno szkół publicznych, jak i niepublicznych. Podejmując to wyzwanie szkoły, mimo iż są instytucjami niekomercyjnymi, muszą mierzyć się z zadaniami w obszarze public relations. „Public relations jest funkcją zarządzania o ciągłym i planowym charakterze, dzięki której organizacja pozyskuje i podtrzymuje zrozumienie, sympatię i poparcie tych, którymi jest zainteresowana obecnie lub może być zainteresowana w przyszłości - przez badanie ich opinii o organizacji, w celu maksymalnego dostosowania do swoich celów i swojej działalności, aby osiągnąć poprzez planowe, szerokie rozpowszechnianie informacji lepszą współpracę ze społeczeństwem oraz skuteczniej realizować swoje interesy"2.

Działania public relations w odniesieniu do placówek oświatowych pełnią funkcję zarządzania, stanowią element promocji i narzędzie marketingu. Podejmowanie działań w tym obszarze jest niezbędne do funkcjonowania szkół i pozyskania uczniów. Czynniki motywujące do budowania pozytywnego wizerunku:

- brak obligatoryjnej rejonizacji uczniów i możliwość wyboru dowolnej placówki oświatowej przez ucznia,

- podniesienie prestiżu szkoły,

- pozyskanie większej ilości kandydatów/uczniów,

- pozyskanie kandydatów z większym potencjałem,

- rozwój instytucji.

Powyższe czynniki skłaniają do podejmowania kroków tworzących zewnętrzne public relations, które „ma charakter wtórny w stosunku do działalności podstawowej” ${ }^{3}$. W istocie, należy więc uregulować i uporządkować wewnętrzny system działania instytucji, placówki oświatowej tak, aby wewnętrzne public relations funkcjonowało nienagannie, a w drugiej kolejności zadbać o działania adresowane do odbiorców zewnętrznych. „Dopiero realizowane na tej bazie zewnętrzne public relations, może przynieść spodziewane rezultaty-ugruntuje oraz upowszechni pozytywny wizerunek jednostki w szerszym otoczeniu" ${ }^{4}$. W przypadku instytucji działających

\footnotetext{
${ }^{1}$ Ustawa z dn.7 września 1991r. o systemie oświaty z późn. zmianami, (publikacja 30-11-2015), Dz.U. z 2015 r. poz 2156 oraz z 2016r.poz 35 i 64, isap.sejm.gov.pl/Download?id=WDU20042562572\&type=3, (dostęp 11.12.2017r.)

${ }^{2}$ S. Cutlip, A Center, Effective Public relations, Englewood Cliffs 1978, s. 15.

${ }^{3}$ A. Pabian, Promocja, nowoczesne środki i formy, Diffin, Warszawa 2008, s. 144.

${ }^{4}$ Tamże, s. 144.
} 
w obszarze edukacji działania w obydwu obszarach częstokroć przenikają się i są nierozłączne.

Wizerunek publiczny to efekt zarządzania tożsamością organizacji, zatem działania PR obejmują trzy obszary:

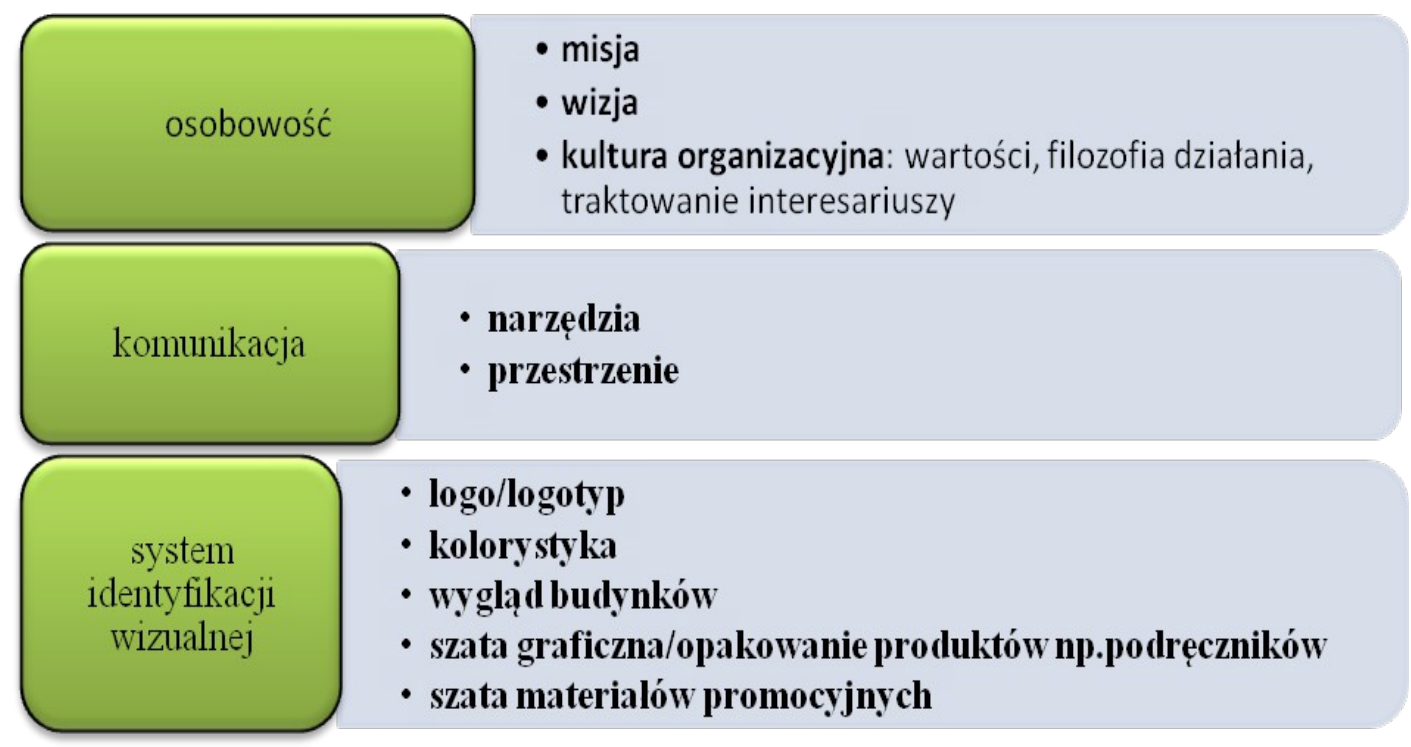

Ryc. Opracowanie własne na podstawie Public Relations w systemie zintegrowanej komunikacji marketingowej A. Szymańska, s. 89-90 5 .

Działania szkół w ramach PR:

- tworzenie systemu identyfikacji wizualnej,

- prowadzenie stron internetowych placówek,

- komunikacja za pomocą dzienników wirtualnych np. Librus Synergia,

- tworzenie prasy szkolnej,

- prowadzenie fanpage'a na FB,

- pozyskiwanie rodziców do czynnego udziału w życiu szkoły,

- dni otwarte, dni kariery.

- informacje prasowe o działaniach.

Pierwsze z analizowanych działań, to prowadzona strona internetowa Zespołu Szkół Ponadgimnazjalnych im T. Kościuszki w Sobolewie ${ }^{6}$.

\footnotetext{
${ }^{5}$ A. Szymańska, Public relations w systemie zintegrowanej komunikacji marketingowej, Oficyna Wydawnicza Unimex, Wrocław 2004, s. 89-90.

${ }^{6}$ Strona internetowa ZSP im. T. Kościuszki w Sobolewie, (brak daty publ.), http://www.losobolew.pl/, dostęp 18.11.2017 r.).
} 


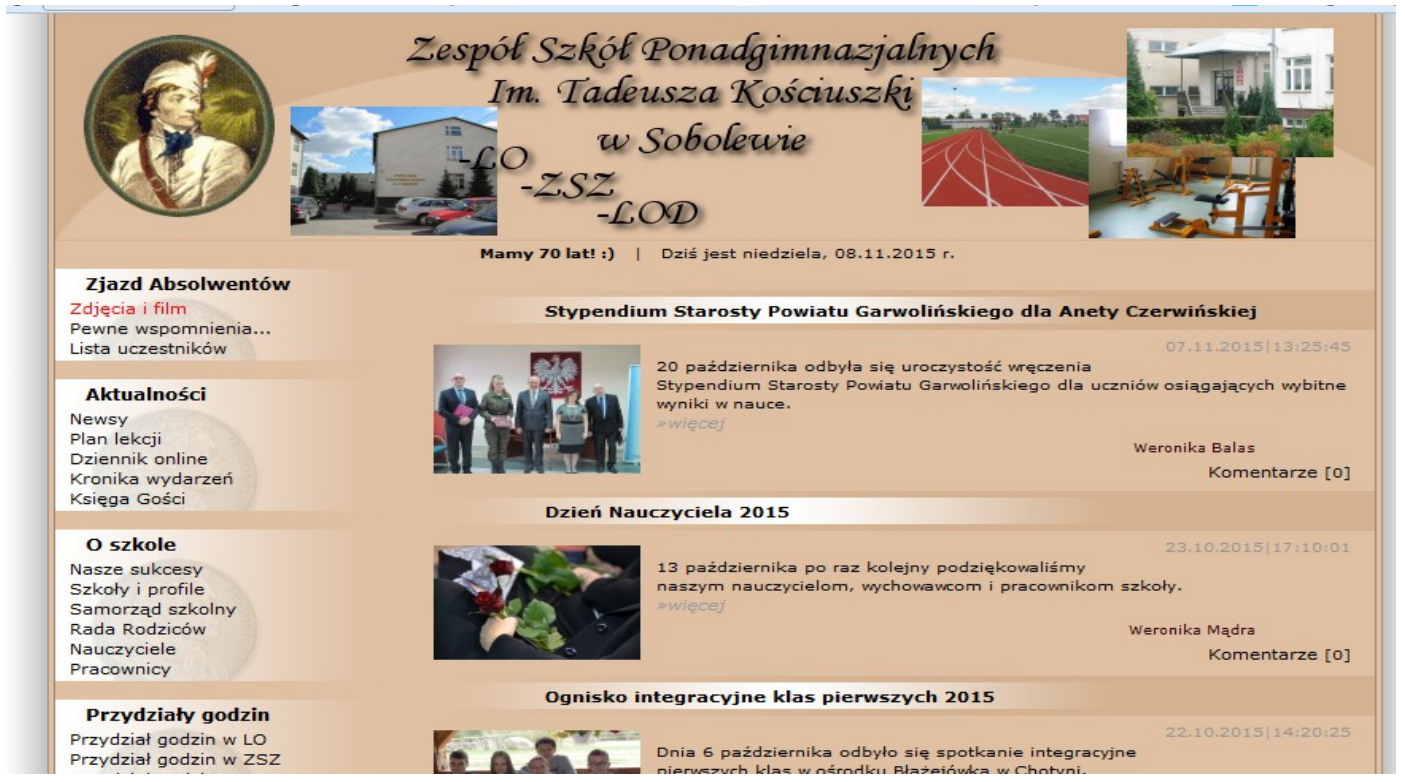

Podstawową funkcją tego przedsięwzięcia jest aspekt informacyjny - odbiorca znajduje istotne informacje na temat działalności i funkcjonowania szkoły. Grupy tematyczne zawierają $\mathrm{n} / \mathrm{w}$ informacje to:

1. aktualności - newsy, plan lekcji, dziennik online, kronikę wydarzeń, księgę gości.

2. o szkole - nasze sukcesy, szkoły i profile, samorząd szkolny, rada rodziców, nauczyciele, pracownicy.

3. dokumenty - statut, wso (wewnątrzszkolny system oceniania) i regulaminy, programy i podręczniki, program wychowawczy.

4. matura 2016: terminarz ,procedury, pomoce na maturze, środowiska na egzamin z informatyki, dostosowania egzamin, przydatne materiały, tematy na maturę ustną.

5. przydziały godzin: wykaz: LO, LOD, ZSZ.

6. historia: historia szkoły, wspomnienia, patron, absolwenci, tabla, dyrektorzy, nauczyciele, samorząd szkolny, rada rodziców, administratorzy.

7. galerie, video: fotokronika, obiekty szkolne, studniówki, zdjęcia klasowe, obozy szkolne, zjazdy absolwentów.

8. „Nikomu Ani Słowa”.

9. dział sportowy.

10. Zespół NIEprzeciętni.

11. dopalacze.

12. przetargi.

13. kontakt, napisz do nas.

14. statystyki odwiedzin.

15. patroni medialni. 
Adresatami są wszyscy partnerzy placówki: nauczyciele, uczniowie, rodzice uczniów; co ważne - odbiorcami mogą być również przyszli kandydaci na uczniów i ich rodzice. Przekaz wypływający z obszaru informacyjnego świadczy o dużej dbałości placówki o jej właściwe funkcjonowanie, o dobrym przepływie informacji i bogactwie działalności programowej oraz pozaprogramowej, wiążącej się z edukacją, wychowaniem, kulturą i profilaktyką. Tym samym, odbiorca zewnętrzny kształtuje przekonanie, że placówka dokłada starań, aby uczniowie otrzymali wszechstronną wiedzę, wykraczającą poza program nauczania, rodzic natomiast może poszerzyć swoje wiadomości o istotne informacje potrzebne do właściwego wychowania, ukształtowania i ochrony dziecka. Potwierdzeniem tego fragmentu przekazu są zastosowane narzędzia wizualne, a więc stonowana, niekrzykliwa kolorystyka, prosta, czytelna czcionka, grupowanie informacji, graficzne rozdzielenie zakładek i wyboldowanie ich nazw. Pod kątem merytorycznym zauważalny jest logiczny porządek informacji, brak nadmiaru przekazywanych treści, umieszczenie ograniczonej liczby zdjęć ułatwiające poprawę percepcji. Zastosowano językowy styl urzędowy we wszystkich publikacjach. Dzięki powyższym działaniom metakomunikat wypływający z postrzegania w/w strony internetowej, utożsamiany przez odbiorcę z cechami placówki informuje o jej profesjonalizmie, rzetelności, powadze, poszanowaniu dla historii i tradycji, uporządkowaniu, logiczności. Są to zatem cechy pożądane dla szkoły dbającej o wysoki poziom nauczania i wychowania oraz skuteczność podejmowanych działań profilaktycznych. Narzędzie to służy do przekazania informacji o misji, wizji i kulturze organizacyjnej placówki, spełnia również rolę komunikatora i buduje system identyfikacji wizualnej przez umieszczenia obrazu sztandaru i nazwy.

Kolejne narzędzie PR służące komunikacji, ale również budujące identyfikację wizualną przez zamieszczenie wizerunku patrona inazwy szkoły jest Dziennik elektroniczny - Librus Synergia, zastosowany przez Zespół Szkół w Sobolewie ${ }^{7}$.

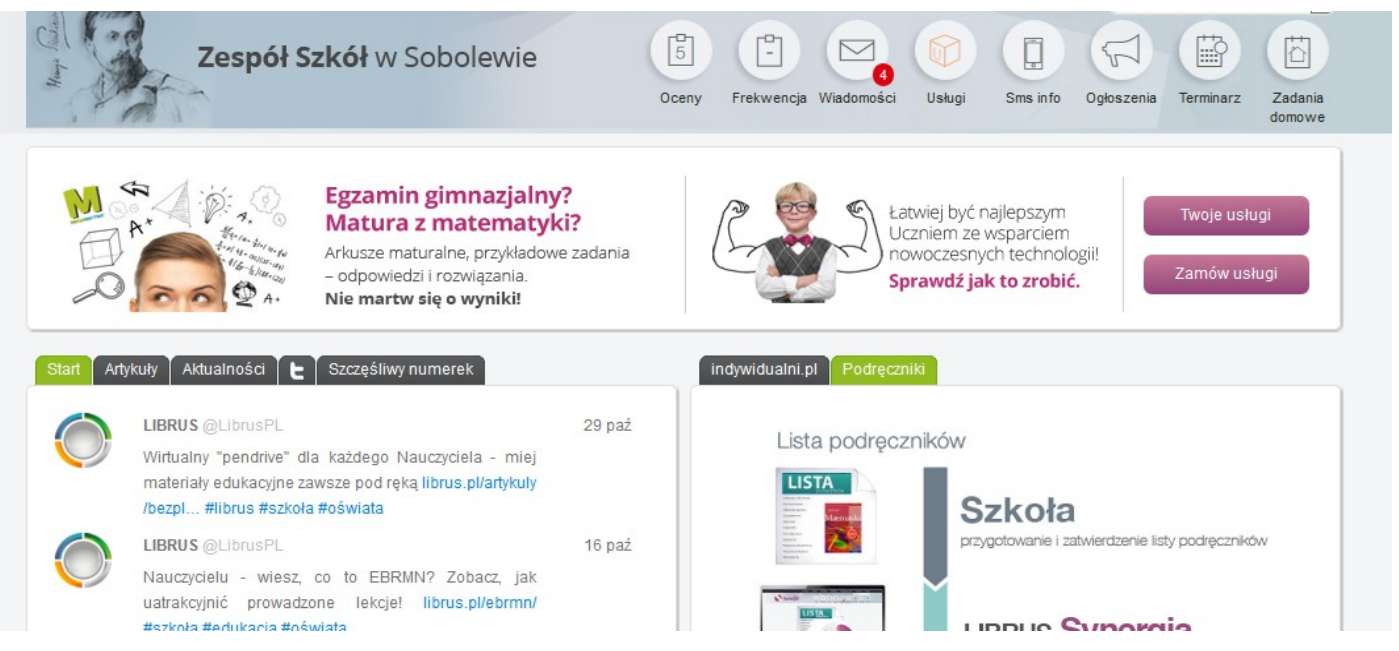

${ }^{7}$ Librus Synergia, (brak dat. publ.), https://dziennik.librus.pl/index, (dostęp 11.02.2017 r.). 


\section{PUBLIC RELATIONS W INSTYTUCJACH NON-PROFIT}

Narzędzie to służy do komunikacji pomiędzy nauczycielami i dyrekcją szkoły a uczniami oraz rodzicami. Zarówno rodzice uczniów, jak i uczniowie posiadają niezależne możliwości logowania się do jednego konta i prowadzenia suwerennych działań, jak też pozyskiwania odpowiednich informacji i prowadzenia korespondencji. Platforma komunikacyjna Librus Synergia zawiera następujące działy tematyczne: oceny, frekwencja, wiadomości, terminarz, zadania domowe, ogłoszenia, organizacja zajęć, plan lekcji, lekcje (realizacja materiału), pliki szkoły (regulaminy, programy, system oceniania itp.), lektury (wykaz), wyniki egzaminów, konkursów, podręczniki (wykaz). Istnieje również możliwość aktywowania dodatkowych platform: Antyplagiat, e-nauczanie, MegaMatma, Kontrola ocen dziecka i frekwencji, Indywidualni (platforma pedagogiczna dla rodziców).

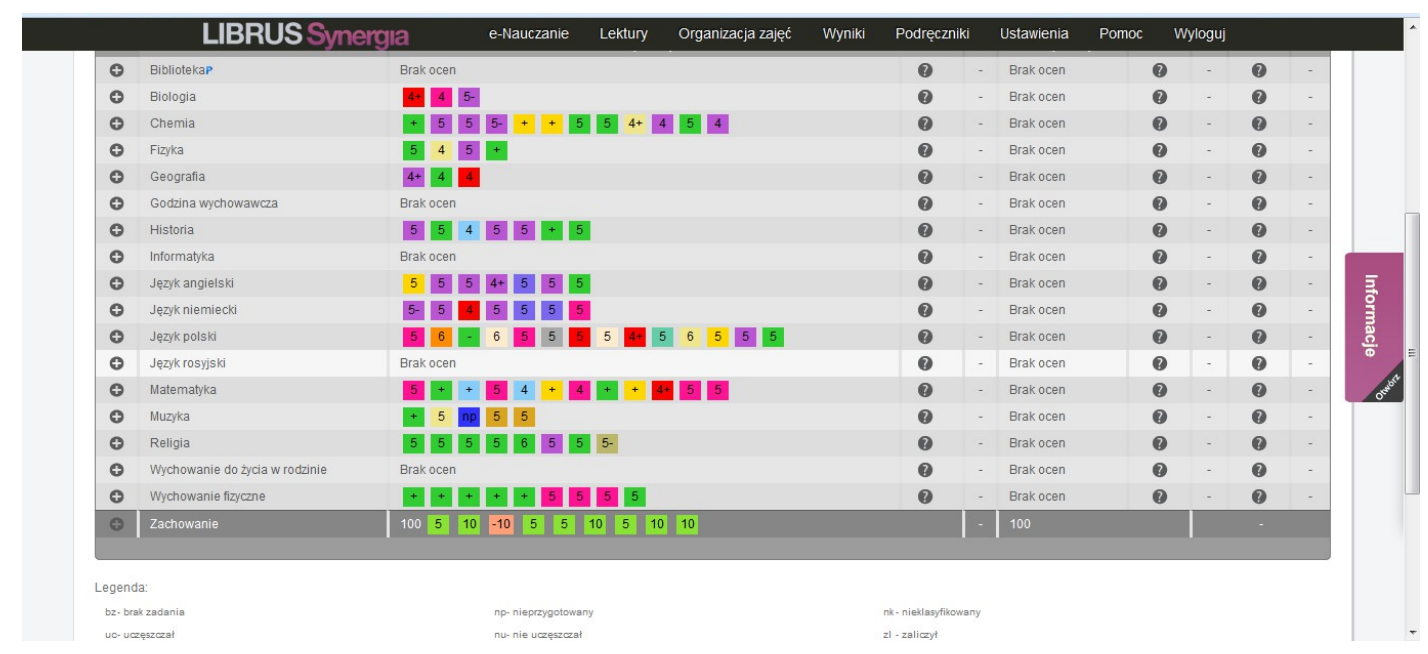

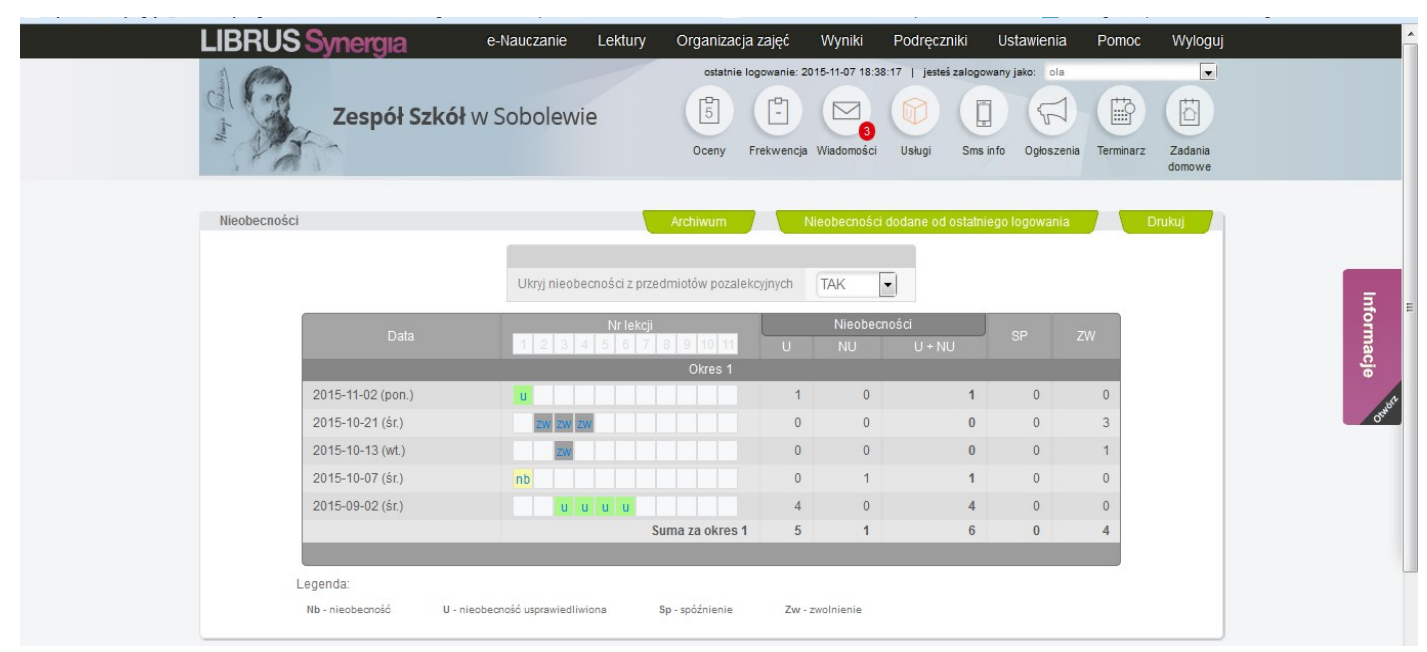


Jak widać, platforma pod kątem komunikacyjnym zawiera wszystkie potrzebne elementy.

Dla realizacji indywidualnych potrzeb istnieje możliwość skorzystania z e-learningu. Stonowana kolorystyka tła i różnobarwne znaczniki rozróżniające istotne informacje wpływają na poprawę percepcję odbiorcy. Czytelność przekazu i brak szumu informacyjnego spowodowanego nadmiarem dają informację odbiorcy - rodzicowi, uczniowi, że misją placówki jest dbałość o wysoki poziom kontaktu z petentem i zapewnienie uczniowi możliwości realizacji powierzonych zadań i stawianych przed nim oczekiwań. Zysk jest oczywisty i czytelny, dotyczy bezpośrednio budowania dobrego wizerunku poprzez:

- ułatwianie komunikacji pomiędzy rodzicami, uczniami i nauczycielami,

- budowanie dobrych relacji, zaufania i współpracy,

- promowanie szkoły przez informowanie rodziców o działaniach, akcjach, projektach,

- pozyskiwanie nowych zasobów (profesje rodziców, działalności, umiejętności),

- informowanie o osiągnięciach szkoły i uczniów,

- uzyskiwanie wsparcia dla szkoły przez czynne ze strony wsparcie rodziców, uczniów, sympatyków w konkursach, w których uczestniczy placówka lub jej przedstawiciele.

Narzędzia wykorzystane w tym działaniu opierają się o kompleksowość, zastosowanie stylu urzędowego, czytelność komunikatów. Skutkuje to czytelnością całej platformy. Metakomunikat kształtujący opinie odbiorcy obejmuje informacje o tym, że instytucja posługuje się profesjonalnym narzędziem w celu wysokiej efektywności i dobrej komunikacji, a to stanowi o jej profesjonalizmie. Celem szkoły, oprócz edukacji i wychowania, jest dbałość o rzetelne wykonywanie ustawowych zadań. Placówka jest więc godna zaufania i warto jej powierzyć edukację swojego dziecka.

Kolejny niezwykle istotny sposób kreowania wizerunku placówki i jednocześnie poszarzania oferty edukacyjnej dla uczniów, to prowadzenie wewnątrzszkolnej prasy. Przykładem jest tu gazetka pt. „Nikomu Ani Słowa”, wydawana przez uczniów Liceum Ogólnokształcącego w Zespole Szkół Ponadgimnazjalnych im. Tadeusza Kościuszki w Sobolewie ${ }^{8}$.

Profesjonalna redakcja i szeroka tematyka obejmują media, kulturę, sferę polityczno-społeczną, sport i profilaktykę. Redakcją i pisaniem artykułów zajmują się sami uczniowie pod opieką dwojga nauczycieli: polonistki i informatyka. Szata graficzna jest stonowana, przejrzysta, daje informacje o profesjonalizmie i budzi zaufanie czytelnika.

Funkcje podstawowe, to tworzenie profesjonalnej prasy i edukacja uczniów w tym zakresie. Zarówno uczniowie piszący do tej gazety, jak i czytelnicy poszerzają swoją wiedzę w zakresie kulturoznawstwa i socjologii. Możliwość współtworzenia

\footnotetext{
${ }^{8}$ Nikomu ani słowa, (brak daty publ.), http://redakcja.mam.media.pl/paper/preview/nikomu-ani-s \%C5\%82owa/15/3/17/, (dostęp 11.12.2017 r.).
} 


\section{PUBLIC RELATIONS W INSTYTUCJACH NON-PROFIT}

projektu wiążącego się z mediami rozwija kreatywność, powoduje współudział w zajęciach fakultatywnych i jest zarazem twórczą profilaktyką. Funkcja pośrednia wynikające z powyższego działania, to poszerzenie oferty edukacyjnej prowadzonej na wysokim poziomie. Pośrednia, ale niezwykle ważna informacja wypływająca ze świadomości tworzenia przez szkołę własnej prasy, to szerokie działania ponadprogramowe placówki, duże zaangażowanie pedagogów i młodzieży, dobre relacje między kadrą a uczniami. Ogólna opinia powstająca po zapoznaniu się z działaniami PR prowadzonymi w tej szkole jest pozytywna, daje przeświadczenie, że jest to placówka dbająca o ucznia, edukację, dobrą atmosferę i właściwe relacje oparte o współpracę i wzajemną troskę oraz wsparcie. Najistotniejszym przesłaniem jest informacja o misji i wartościach kultywowanych w w/w placówce, które w centrum stawiają dobro ucznia i wysoki poziom edukacji.

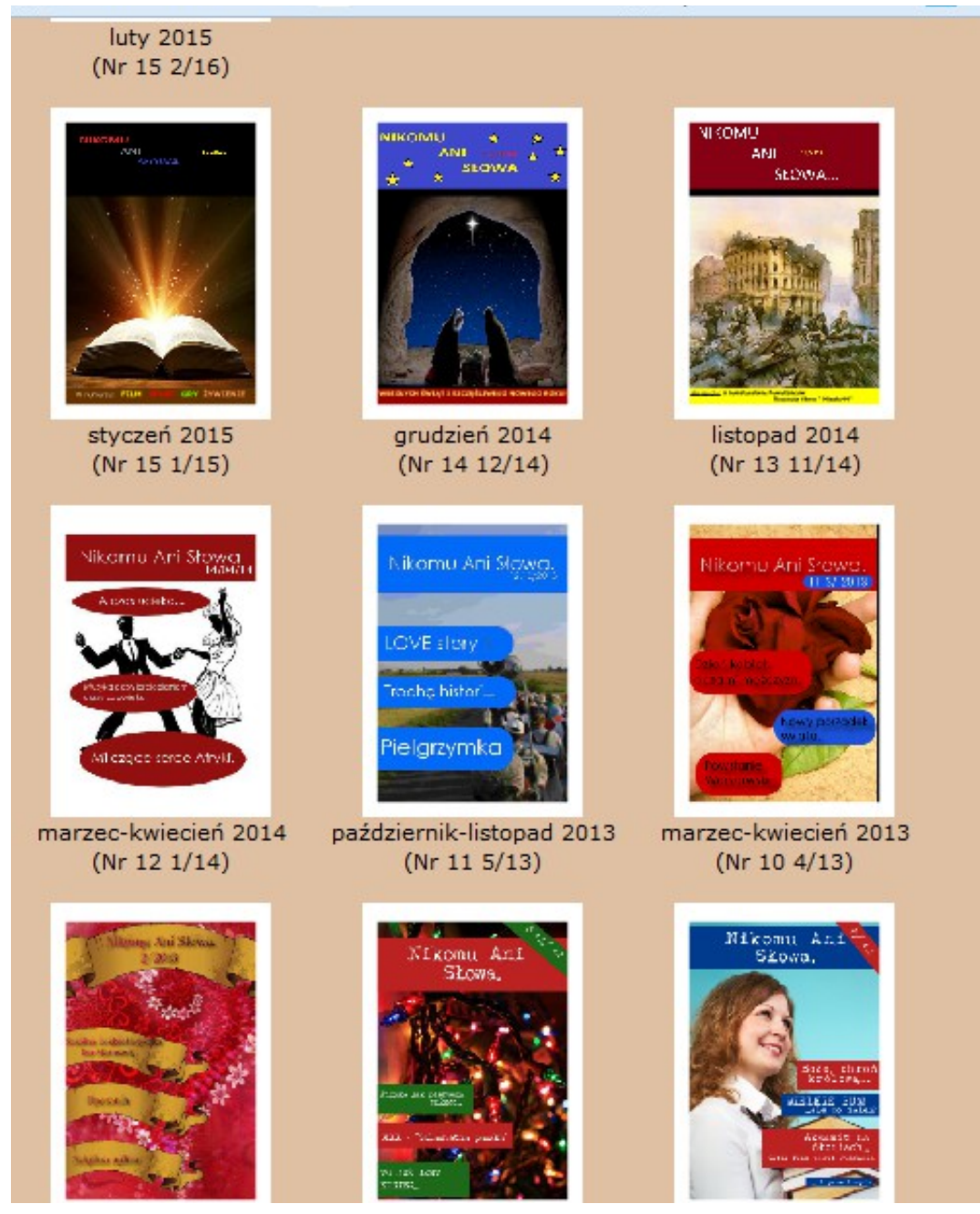



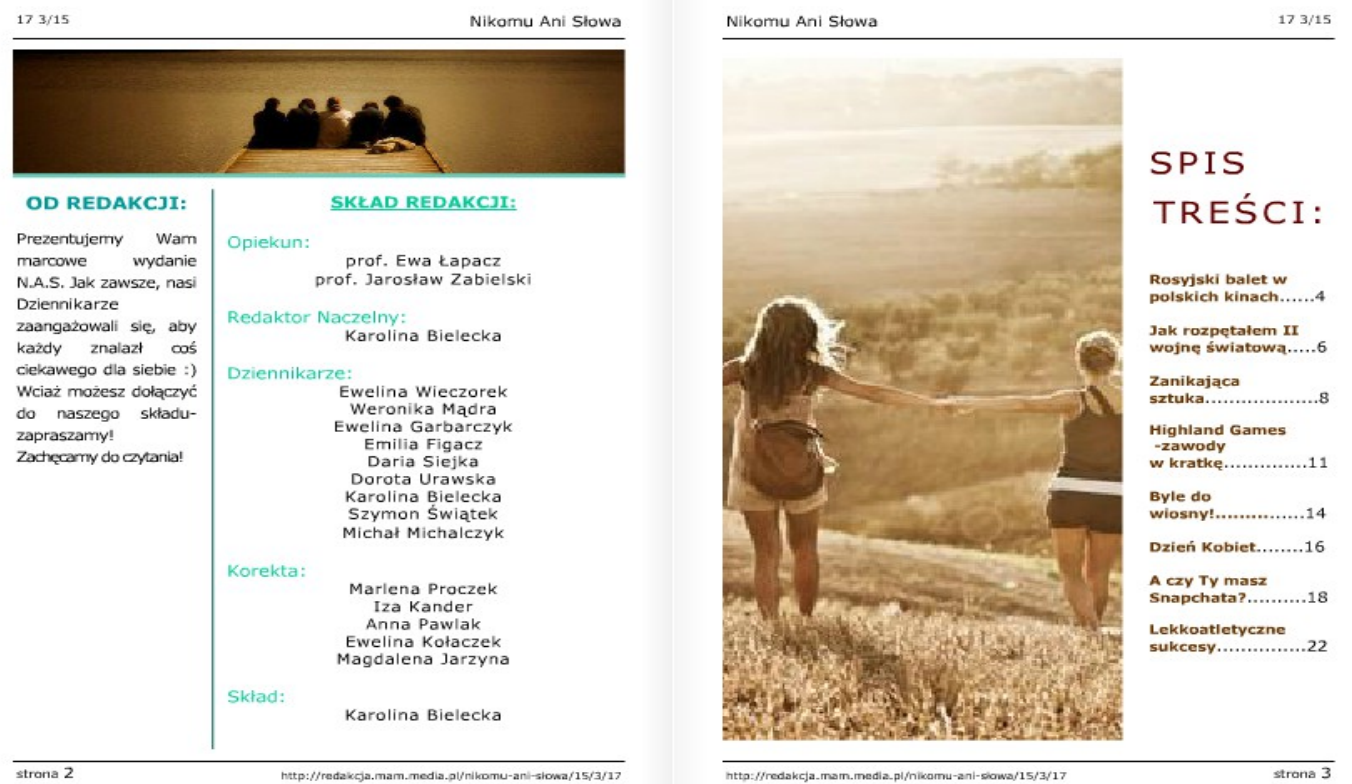

Odmiennym sposobem konstrukcji pozytywnego obrazu instytucji jest prowadzenie fanpage'a szkoły na Facebooku. Ma on na celu poprawę komunikacji pomiędzy szkołą a uczniami oraz zachęcenie uczniów do współtworzenia placówki i czynnego uczestnictwa w jej życiu. Dobrym przykładem jest Publiczne Gimnazjum im. Jana Pawła II w Żelechowie ${ }^{9}$.
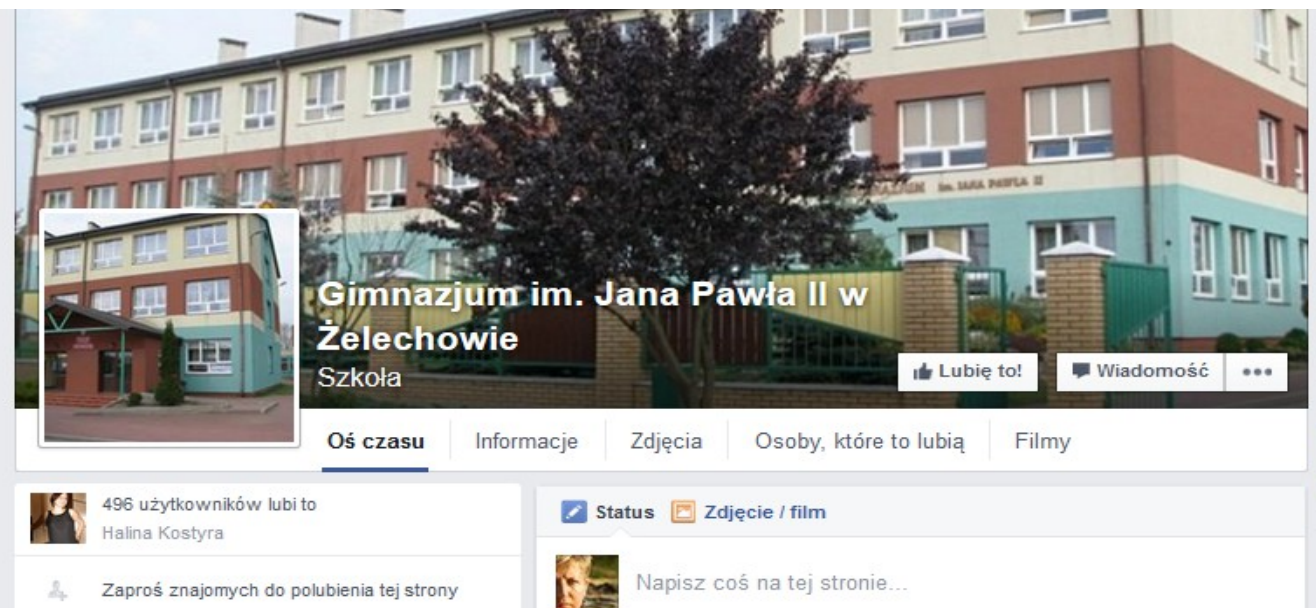

Status Zdjęcie / film

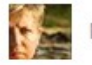

\footnotetext{
${ }^{9}$ PG w Żelechowie - fanpage na FB, (brak daty publ.), https://www.facebook.com/zsogrodowa/? ref=ts\&fref=ts, (dostęp 18.12.2017 r.).
} 
Funkcje podstawowe stawiane przed tym działaniem, to bezpośredni kontakt z uczniami w każdym czasie. Uczniowie w większości pozostają bowiem online przez całą dobę, a przynajmniej przez jej większą część. Najistotniejsze jest przekazywanie informacji o działaniach i akcjach prowadzonych w szkole, proponowanych i funkcjonujących zajęciach pozalekcyjnych, propagowanie wydarzeń kulturalnych i relacji z wydarzeń wiążących się z funkcjonowaniem szkoły. To, co istotne, we współczesnym społeczeństwo informacyjnym, to odchodzenie od treści, a posługiwanie się obrazem. Ten sposób przekazu jest niezwykle istotny i jest stosowany przy tworzeniu galerii na Facebooku.

Funkcja pośrednia, znamienna dla tego sposobu komunikacji, to budowanie dobrych, bliskich relacji z uczniami. Styl językowy jest więc zbliżony do stylu potocznego, oczywiście istotnym jest tu także zachowanie poszanowania ogólnie przyjętych norm społecznych. Tworzony jest $w$ ten sposób dobry wizerunek szkoły pozostającej w bliskich relacjach z uczniami; szkoły nastawionej również na kształtowanie ucznia w zakresie pozytywnej postawy społecznej i emocjonalnej. Dzięki temu, łatwiej jest placówce edukacyjnej pozyskać uczniów oczekujących od placówki edukacyjnej nie tylko nauki, ale też dobrych relacji, więzi i wsparcia społecznego; szkoły nadążającej za zmianami społecznymi, technologicznymi, otwartej na nowości i zmniejszenie dystansu na linii pedagog - uczeń. Wydaje się też, że rodzice uczniów trudniejszych społecznie, zamkniętych na otoczenie, chętniej zainteresują się w/w placówką z uwagi na konieczność kształtowania w dziecku otwartości nauki właściwych relacji międzyludzkich. Zatem, na pierwszy plan wysuwają się ponownie: misja i wizja szkoły, najważniejszy jest tu uczeń i jego osobowość, istotne są też wyniki w nauce i szeroko pojęta edukacja, również ta pozalekcyjna. Placówka stawia na kształtowanie młodego człowieka i jego dobre relacje z innymi ludźmi w wielu działaniach pozalekcyjnych, dodatkowych. Oferta edukacyjna jest zatem równie istotna i bogata, wiąże się funkcjonowaniem chóru szkolnego, zajęciami plastycznymi, artystycznymi, wspólnym spędzaniem czasu podczas dyskotek i innych zajęć służących relaksowi i budowaniu wspólnych więzi. I choć podstawowym adresatem tego działania są uczniowie, to rodzice, jako adresat poboczny, otrzymują pozytywną informację o szkole.

Bardzo wysoko cenionym narzędziem w budowaniu wizerunku placówek oświatowych są informacje prasowe o działaniach szkoły i prowadzonej współpracy z rodzicami. „Naczelną zasadą public relations jest (...) stwierdzenie, że media transportują komunikat między organizacja, a grupami odniesienia. (...) Public relations zatem to specyficzny rodzaj komunikacji, bazujący oczywiście na ogólnym mechanizmie komunikacji, lecz specyficznie ukierunkowany" ${ }^{10}$. Ukierunkowanie polega na dotarciu do grup społecznych zainteresowaniem edukacją w kontekście wychowania i edukacji swoich dzieci czy wnucząt. Reprezentatywną dla dobrych praktyk komunikacyjnych jest publikacja o uroczystości przygotowanej przez nauczycieli i uczniów Zespołu Szkół w Sobolewie - XII Biesiadzie Rodzinnej w Sobolewie ${ }^{11}$.

\footnotetext{
${ }^{10}$ M. Fleischer, Corporate identity i public relations, Dolnośląska Szkoła Wyższa Edukacji Towarzystwa Wiedzy Powszechnej, Wrocław 2003, s. 177.

${ }^{11}$ XII Biesiada Rodzinna w Sobolewie, (brak daty publ.), http://www.egarwolin.pl/index.php/rozrywka/5311-
} 
Informacja prasowa przygotowana przez pracowników szkoły wraz z dokumentacją fotograficzną została przekazana do informacyjnego portalu regionalnego eGarwolin, ${ }^{12}$ obejmującego zasięgiem działania powiat garwoliński. Informacja zawiera relację ze spotkania integracyjnego dedykowanego uczniom i rodzicom uczniów w/w placówki przygotowanego z okazji dnia dziecka, bardzo bogatą ofertę służącą rekreacji, zdrowemu stylowi życia, propagującą dobre relacje międzyludzkie, współdziałanie w grupie społecznej i wsparcie placówki edukacyjnej tworzy istotną podbudowę do pozyskiwania kolejnych uczniów i nawiązywania współpracy z rodzicami, dzięki czemu działania na rzecz uczniów i placówki mogą być bogatsze i ciekawsze, asami uczniowie mogą korzystać z szerszej oferty. Pośrednio informacja przekazywana do ogółu społeczeństwa tworzy obraz szkoły dbającej o edukację i modelowanie społeczne młodych ludzi.

Tożsamą kreacją wizerunku szkoły jest publikacja dotycząca dni otwartych prowadzonych w Liceum Ekonomicznym w Garwolinie pt. Gimnazjalisto, dowiedz się, dlaczego warto wybrać, ,ekonomik"'13.

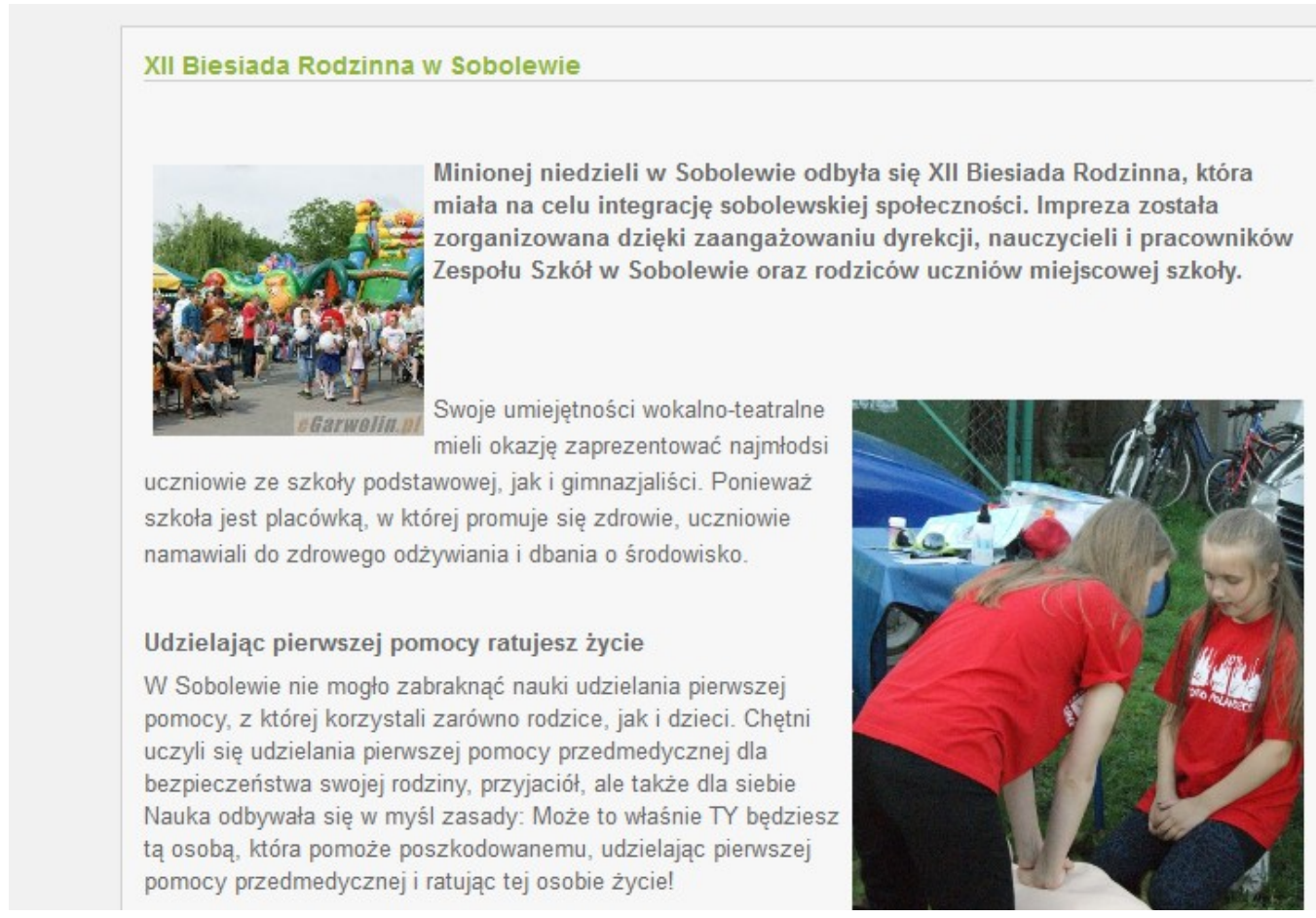

xii-biesiada-rodzinna-w-sobolewie, (dostęp 11.12.2017 r.).

${ }^{12}$ eGarwolin - Regionalny Portal Internetowy, egarwolin.pl, (dostęp 18.12.2017 r.).

${ }^{13}$ Gimnazjalisto dowiedz się dlaczego warto wybrać ekonomik, (publikacja 01.04.2012 r.), http://www.grajdol.pl/garwolin_4746_gimnazjalisto_dowiedz_sie_dlaczego_warto_wybrac_ekonomik,9, (dostęp 18.12.2017 r.). 
Powyższa informacja skonstruowana w stylu publicystycznym przybliża atuty szkoły, jej otwartość na uczniów oraz potrzebę edukowania na najwyższym poziomie. Nie pominięto również informacji o bogatej ofercie edukacji ponadprogramowej i pozalekcyjnej wiążącej się często z rekreacją i budowaniem dobrych relacji rówieśniczych.

Funkcje publikacji prasowych promujących szkoły, profesjonalizm działań i nastawienie na indywidualne traktowanie ucznia oraz dobre funkcjonowanie społeczne spełniają kilka zadań, są to przede wszystkim:

- promocja szkoły w lokalnym społeczeństwie,

- pozyskiwanie uczniów,

- informowanie niezaangażowanych rodziców o ofercie placówki i podejmowanych działaniach na rzecz uczniów i społeczności,

- pozyskiwanie rodziców do współpracy,

- budowanie dobrych relacji i zaufania między stronami.

Aspekt socjologiczny w budowaniu wizerunku firmy, placówki oświatowej jest niezwykle ważny, gdyż „badania sieci powiązań dowodzą, że procesy wymiany informacji nie zachodzą w abstrakcyjnych sytuacjach rynkowych, lecz w ramach więzi społecznych" ${ }^{14}$. Upowszechnianie informacji o pozytywnym wizerunku szkoły skutkuje dwojakim zyskiem, stanowi formę reklamy i bezpośrednio daje efekt marketingu tradycyjnego i szeptanego; informuje również o kultywowaniu przez placówkę wartości postrzeganych jako istotne przez potencjalnych klientów, zwiększa więc prawdopodobieństwo sprzedaży usług. Biorąc pod uwagę fakt, że strategiczne decyzje podejmowane są przez nabywcę $\mathrm{w}$ znacznym stopniu na poziomie paralelizmu wartości i empatii - jest to działanie skuteczne. Wszystkie te założenia mają budować dobry wizerunek szkoły, mają pełnić funkcję informacyjną i zarazem stanowić formę reklamy, a przez to budować rynek zbytu na usługi edukacyjne przez pozyskiwanie kolejnych uczniów.

Funkcja informacyjna może mieć formę potencjalną lub użyteczną. Powyższe kroki budujące wizerunek szkół spełniają funkcje potencjalne i użyteczne, gdyż powiększają zasób wiedzy odbiorcy. Równocześnie, funkcja sterująca wywołuje zamierzony efekt, reakcję u odbiorcy polegającą na kształtowaniu pozytywnego obrazu. Szkoły starają się wpłynąć na tworzenie swojego wizerunku w lokalnej społeczności tak, aby za pomocą funkcji modelowania uwypuklić najistotniejsze informacje i stworzyć obraz instytucji preferującej wartości, na które występuje zapotrzebowanie społeczne. Ponieważ niemożliwe jest równoczesne rozpoznanie wszystkich aspektów funkcjonowania informacji, podczas odbioru dokonuje się uproszczenia, na skutek czego odbiorca formułuje swój obraz, model szkoły, który może być następnie wykorzystany w procesie zarządzania palcówką i pozyskiwania klientów. Świadomość tego procesu pozwala na prowadze-

\footnotetext{
${ }^{14}$ S. Wiesender, T.Cerny, Skuteczne zarządzanie reputacja I spójny image, Best Press Wydawnictwo, Warszawa 2008, s. 40.
} 
nie zrównoważonej konkurencji pomiędzy placówkami oświatowymi sektora publicznego i prywatnego.

Coraz częściej, z coraz większą oczywistością, instytucje zajmujące się edukacją uzmysławiają sobie konieczność budowania swojego kierunku, rozwijania go i kształtowania w odniesieniu do zmian zachodzących na rynku edukacyjnym. „Klienci kupują markę, image, świat przeżyć oferowany przez dana organizację (...)" ${ }^{15}$. Zjawisko to nie tylko generuje potrzebę, zmusza resort oświaty do podejmowania intensywnych działań w tym zakresie, gdyż wynikiem zaniechań lub błędów może być kres funkcjonowania poszczególnych placówek, a co za tym idzie problemy dla zatrudnionych tam osób. Dbanie o dobre imię instytucji to pośrednio dbanie o dobrą przyszłość zatrudnionych w niej osób.

\section{BIBLIOGRAFIA}

Budzyński W., Public Relations. Strategia i nowe techniki kreowania wizerunku, Poltext, Warszawa 2008.

Cutlip S., Center A., Effective Public relations, Englewood Cliffs 1978.

Fleischer M. , Corporate identity i public relations, Dolnośląska Szkoła Wyższa Edukacji Towarzystwa Wiedzy Powszechnej, Wrocław 2003.

Pabian A. , Promocja, nowoczesne środki i formy, Diffin, Warszawa 2008.

Szymańska A, Public relations w systemie zintegrowanej komunikacji marketingowej, Oficyna Wydawnicza Unimex, Wrocław 2004.

S. Wiesender, T. Cerny, Skuteczne zarządzanie reputacja I spójny image, Best Press Wydawnictwo, Warszawa 2008.

\section{ŹRODŁA INTERNETOWE}

XII Biesiada Rodzinna w Sobolewie, (data publ. 01.04.2012 r.), http://www.egarwolin.pl/index.php/rozrywka/5311-xii-biesiada-rodzinna-w-sobolewie.

eGarwolin - Regionalny Portal Internetowy, egarwolin.pl.

Gimnazjalisto dowiedz się dlaczego warto wybrać ekonomik, (publikacja 01.04.2012 r.) , http://www.grajdol.pl/garwolin_4746_gimnazjalisto_dowiedz_sie_dlaczego_warto_wybrac_ekonomik,9.

Librus Synergia, (brak dat.publ.), https://dziennik.librus.pl/index.

Nikomu ani słowa, (brak daty publ.),

http://redakcja.mam.media.pl/paper/preview/nikomu-ani-s\%C5\%82owa/15/3/17/.

PG w Żelechowie-fanpage na FB, (brak daty publ.),

https://www.facebook.com/zsogrodowa/?ref=ts\&fref=ts.

\footnotetext{
${ }^{15}$ M. Fleischer, art. cyt. s. 7 .
} 
Ustawa z dn.7 września 1991r. o systemie oświaty z późn. zmianami, (publikacja 30.11.2015), Dz.U. z 2015r.poz2156 oraz z 2016r.poz 35 i 64) (isap.sejm.gov.pl/Download?id=WDU20042562572\&type=3 .

ZSP im. T. Kościuszki w Sobolewie - strona internetowa, (brak daty publ.), http://www.losobolew.pl/.

\section{OAUTORCE:}

mgr Danuta Kalinowska - absolwentka Filologii Polskiej na UW, doktorantka z wolnej stopy na Uniwersytecie Warmińsko-Mazurskim w Olsztynie pod opieką naukową dr hab. Arkadiusza Dudziaka. Zawodowo zajmuje się profilaktyką w Komendzie Powiatowej Policji w Garwolinie i dydaktyką w Pedagogium Wyższej Szkole Nauk Społecznych w Warszawie. KONTAKT:dankakalinowska@o2.pl 


\section{OBLICZA MEDIÓW | KOMUNIKACJ|}


kuLTura - мeDia- TeoLogia

ISSN 2081-8971

$2017 \mathrm{nr} 30$, s. 137-150.

\section{Dziennikarstwo śledcze w przestrzeni lokalnej. Analiza prasoznawcza publikacji „Dziennika Zachodniego” z 2015 roku}

\section{Investigative journalism in the local space. \\ The scientific analysis of the publications in "Dziennik Zachodni" since 2015.}

\section{STRESZCZENIE:}

AUTORKA DOKONAŁA ANALIZY ZAWARTOŚCI ROCZNIKA „DZIENNIKA ZACHODNIEGo” Z 2015 ROKU POSZUKUJĄC PUBLIKACJI DZIENNIKARSKICH O CHARAKTERZE ŚLEDCZYM. MOTYWACJĄ DO PRZEPROWADZENIA ANALIZY BYŁY PYTANIA BADAWCZE: ILE JEST TAKICH MATERIAŁÓW

W PRASIE LOKALNEJ NA PRZYKŁADZIE ,DZIENNIKA ZACHODNIEGO”, JAK CZESTO SĄ PUBLIKOWANE, KTO JE PISZE, O KIM PISZE, ORAZ JAKĄ POWIERZCHNIE MAJĄ TE TEKSTY WZGLĘDEM INNYCH MATERIAEÓW DZIENNIKARSKICH.

PIERWSZA CZEŚĆ ARTYKUŁU ZARYSOWUJE NAM HISTORIE DZIENNIKARSTWA ŚLEDCZEGO W USA I MEDIÓW

W POLSCE PO 1989 R. W DALSZEJ KOLEJNOŚCI ZAPREZENTOWANE SĄ FUNKCJONUJĄCE W LITERATURZE DEFINICJE DZIENNIKARSTWA ŚLEDCZEGO, A TAKŻE NAJWAŻNIEJSZA PROBLEMATYKA I CECHY TYCH PUBLIKACJI. W CZĘŚCI KOLEJNEJ AUTORKA PRZEDSTAWIA CEL SWOICH BADAŃ, ORAZ METODOLOGIĘ, A NASTĘPNIE WYNIKI TYCH BADAŃ.

\section{SŁOWA KLUCZOWE:}

POLSKIE DZIENNIKARSTWO ŚLEDCZE, DZIENNIKARSTWO LOKALNE, PRASA LOKALNA
ABSTRACT:

THE AUTOR ANALYZED „DZIENNIK ZACHODNI" YEARBOOK OF 2015 SEARCHING INVESTIGATIVE JOURNALISM PUBLICATIONS. MOTIVATION FOR THE ANALYSIS WAS RESEARCH QUESTIONS: FREQUENCY OF PUBLICATIONS, WHO IS ITS AUTOR, WHO THE AUTOR IS WRITING ABOUT, WHAT IS IT'S SURFACE COMPARED TO SURFACE OF OTHER PUBLICATIONS.

THE FIRST PART OF THE ARTICLE OUTLINES THE HISTORY OF INVESTIGATIVE JOURNALISM IN THE US AND THE MEDIA IN POLAND AFTER 1989. IN THE SECOND PART OF THE ARTICLE ARE PRESENTED FUNCTIONING DEFINITIONS OF INVESTIGATIVE JOURNALISM IN LITERATURE, AS WELL AS THE MOST IMPORTANT ISSUES AND FEATURES OF THESE PUBLICATIONS. IN THE NEXT PART THE AUTHOR PRESENTS THE PURPOSE OF HIS RESEARCH, THE METHODOLOGY AND THE RESULTS OF THESE STUDIES.

\section{KEYWORDS:}

POLISH INVESTIGATIVE JOURNALISM, LOCAL JOURNALISM, LOCAL PRESS 
$\mathrm{D}$ ziennikarstwo śledcze można niewątpliwie określić mianem społecznej misji. Jest to jednocześnie jedna z najtrudniejszych odmian tego zawodu - biorąc pod uwagę fakt, że rezultaty pracy dziennikarza śledczego są oddalone w czasie, a powstanie tekstu dziennikarskiego, jako zwieńczenia tej pracy, nie zawsze jest możliwe. Dziennikarz śledczy często boryka się z utratą zdrowia i życia ze strony tych, których interesy narusza; nierzadko zmaga się również z długotrwałymi i wyniszczającymi procesami sądowymi w sprawach o naruszenie dóbr osobistych czy zniesławienie. Między innymi z tych powodów redakcje niechętnie podejmują się realizacji trudnych i kontrowersyjnych tematów. Wielu pracowników prowadzących dziennikarskie dochodzenia nie lubi, gdy określa się ich mianem dziennikarzy śledczych. Traktują oni swą pracę po prostu jako robienie czegoś pożytecznego - co jest dla nich istotą tego zawodu, w myśl zasady, iż „w modelowym ujęciu dziennikarze nie mają własnych preferencji politycznych, redakcje - linii programowych, świat mediów, wolny od nacisków ekonomicznych będących efektem splotu interesów biznesu i polityki, z jednakową determinacją tropi nieprawidłowości władzy, nadaje im rozgłos"1.

Niektórzy uważają, że dziennikarstwu śledczemu dała początek afera Watergate w USA; inni, że jego źródeł należy szukać znacznie wcześniej, bo w 1690 roku Bostonie, kiedy to Benjamin Harris ujawnił w swym periodyku „Public Occurrences, Both Foreign and Domestick” fakt torturowania jeńców francuskich przez Indian służących Anglikom².

Niestety, wkrótce po publikacji władze zamknęły tytuł Benjamina Harrisa i przez długie lata nikt nie podjął się realizacji misji dziennikarskiej w takim stylu. Stało się to dopiero w latach 70., kiedy to za sprawą dwóch dziennikarzy „The Washington Post”, świat dowiedział się o nadużyciach prezydenta Nixona i jego otoczenia. Dwaj dziennikarze, Carl Bernsten i Bob Woodward z „The Washington Post”, stali się bohaterami i tej oceny nie zmienia nawet ujawniony niedawno fakt, że byli wspomagani, a właściwie naprowadzani na trop przez ówczesnego zastępcę szefa FBI”’3.

Afera Watergate na stałe już stała się częścią kanonu dziennikarstwa śledczego i uchodzi za przykład i często początek tej odmiany dziennikarstwa. Długa tradycja dziennikarstwa śledczego w Stanach Zjednoczonych, znanego tam jako investigative reporting, czyni go powszechnym zjawiskiem w gazetach codziennych. Wojciech Adamczyk zauważa wiele analogii między publikacjami o naturze śledczej w Stanach Zjednoczonych i w Polsce. Jak pisze, „owe podobieństwa dotyczą zarówno poruszanej tematyki, zastosowanych metod pozyskiwania informacji oraz ich weryfikacji, jak i skutków tych dochodzeń odczuwalnych w obszarach polityki, ekonomii i stosunków społecznych" ${ }^{4}$

\footnotetext{
${ }^{1}$ I. Hofman, Polityka, media, społeczeństwo. Studia i szkice, Toruń 2007, s. 84.

${ }^{2}$ W. Adamczyk, Ujawnianie korupcji i nadużyć władzy w działalności amerykańskich muckrakerów, w: M. Palczewski, M. Worsowicz (red.), Dziennikarstwo śledcze. Teoria i praktyka w Polsce, Europie i Stanach Zjednoczonych, Łódź 2006, s. 16.

${ }^{3}$ T. Goban-Klas, Dziennikarstwo śledcze w USA. Powstanie, rozkwit, rozkład, w: M. Palczewski, M. Worsowicz (red.), Dziennikarstwo śledcze..., dz. cyt., s. 10.

${ }^{4}$ W. Adamczyk, Rzecz o kontynuacji: amerykańskie wzorce investigative reporting ${ }^{w}$ praktyce polskich reporterów śledczych, w: News i dziennikarstwo śledcze wobec wyzwań XXI wieku, M. Palczewski, M.
} 


\section{OBLICZA MEDIÓW I KOMUNIKACJI}

przy czym autor ten nie upatruje przyczyn podobieństwa w naśladownictwie, z uwagi na dość krótką popularyzację investigative reporting $w$ Polsce.

Ujawnianie, dociekanie i wyciąganie na światło dzienne różnych patologii dało początek stylowi dziennikarskiemu, który wobec władz i elit wypełnia jedną z najważniejszych funkcji mediów - funkcję kontrolną i krytykującą. Dodajmy, że uprawianie tego zawodu możliwe jest $\mathrm{w}$ tych systemach politycznych, gdzie istnieje wolność słowa, ponieważ „podstawą politycznej krytyki i kontroli jest niezależność (wolność od nacisków) podmiotów formułujących sądy i opinie, niezależność ta musi być oparta na ogólnej wolności informacji" ${ }^{5}$. Jednak, jak wykazuje analiza amerykańskiej organizacji Freedom House National Headquarters, wolność prasy jest na świecie dobrem deficytowym: państw, gdzie media mogą wypełniać swą misję i rolę policjanta wobec władz, jest w skali globu niewiele (rysunek $\mathrm{nr}$ 1). Tymczasem, niezależne media cieszące się wolnością słowa są filarem i strażnikiem demokracji, a dziennikarze dążący do prawdy, tropiący nadużycia różnego rodzaju elit, będą zawsze cieszyli się poparciem społecznym.

\section{Rysunek nr 1.}

\section{MAP OF PRESS FREEDOM}

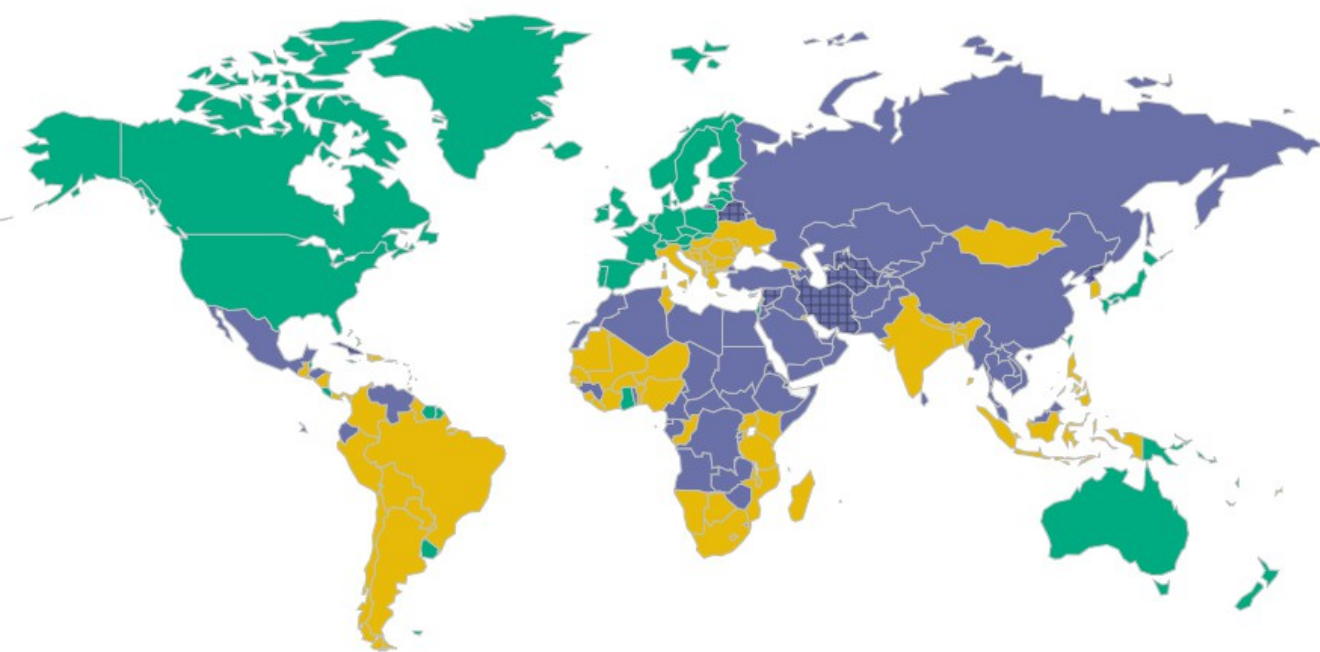

Freedom of the Press

Free Partly Free Not Free 10 Worst of the Worst

\section{Źródło: www.freedomhouse.org}

Worsowicz (red.), Łódź 2010, s. 113.

${ }^{5}$ S. Michalczyk, Komunikowanie polityczne. Teoretyczne aspekty procesu, Katowice 2005, s. 129. 
Współczesne polskie dziennikarstwo śledcze rozwija się od 1989 roku, co ma związek z przekształceniami strukturalnymi prasy, radia i telewizji. Materiały dziennikarskie odkrywające nieprawidłowości i skandale w świecie polityki, biznesu, organizacji społecznych i religijnych na stałe zagościły na łamach gazet, w eterze i na wizji. Przed 1989 r. komunistyczni decydenci poprzez działania cenzorów i rozmaite represje nie dopuszczali do ujawniania patologii. Dopiero przemiany uwolniły potencjał zawodowy dziennikarzy i dały polskim mediom możliwość wypełniania pierwotnych funkcji wobec społeczeństwa, a co za tym idzie, zyskały przydomek tzw. „,czwartej władzy”. Odtąd media „pełnią rolę zwierciadła opinii publicznej, adwokata obywateli, organu narodu oraz pośrednika w kształtowaniu woli politycznej”6. I tak, w maju 1989 r. powstał pierwszy niezależny dziennik: „Gazeta Wyborcza”, który zaanektował wielu dziennikarzy „Tygodnika Mazowsze”. Rozpoczął się ciąg zmian na rynku mediów. Nastąpiła likwidacja cenzury, nowelizacja prawa prasowego (która miała być tylko tymczasowa; docelowo planowano napisać ustawę od nowa, co nigdy nie doszło do skutku) i demontaż RSW „Prasa-Książka-Ruch”. Zaczęto anektować tytuły koncernu „Prasa-Książka-Rucha”, a także zakładać nowe pisma o zasięgu ogólnopolskim i lokalnym. Według Ryszarda Kowalczyka w latach 1990-1991 utworzono 80 tytułów regionalnych oraz 615 lokalnych, podczas gdy niewiele z pism istniejących przed 1989 rokiem przetrwało ${ }^{7}$. Nastąpił dynamiczny rozwój prasy lokalnej, ale „zakładane w wielu miastach nowe dzienniki w większości nie zdołały utrzymać się na rynku, a ich założyciele przekonali się szybko, że rynek prasowy brutalnie weryfikuje idealistyczne założenia" ${ }^{8}$.

\section{Ustalenia definicyjne}

Dziennikarstwo śledcze wraz z wolnością słowa zagościło na stałe w polskich mediach - stało się też przedmiotem zainteresowania badaczy. Na polskim gruncie istnieje dziś wiele definicji dziennikarstwa śledczego, uzupełniających się lub powielających - zarówno wśród praktyków, jak i teoretyków mediów. Stanisław Michalczyk zauważa, że w medioznawstwie dziennikarstwo śledcze jest jednym z trzech typów idealnych i stoi w typologii obok dziennikarstwa informacyjnego i interpretacyjnego, a sam dziennikarz śledczy „występuje w roli "czuwającego psa" (watchdogs, Wachshund), oraz rzecznika opinii publicznej. Jego podstawowym zadaniem jest krytyka i kontrola, ma duży zakres autonomii i stawiane są mu wyso-

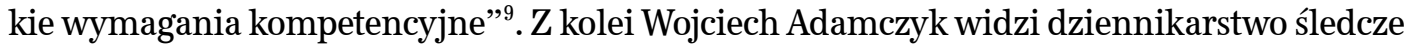
jako demaskowanie „świadomie ukrytych przed społeczeństwem bezprawnych i amoralnych zachowań ludzi władzy oraz wielkiego biznesu" ${ }^{10}$. To samo, acz innymi słowami, mówi nam o dziennikarstwie śledczym dziennikarz Bertold Kittel, twierdząc, iż „dzienni-

\footnotetext{
${ }^{6}$ K. Brzoza, Rola „Dziennika Zachodniego” w wyborach samorządowych 2014 r., w: Oblicza mediów lokalnych i regionalnych, S. Michalczyk, D. Krawczyk (red.), Mikołów 2016, s. 67.

${ }^{7}$ R. Kowalczyk, Media lokalne w Polsce. Podręcznik akademicki, Poznań 2009, s. 96-100.

${ }^{8}$ J. Braun, Potęga czwartej władzy, Warszawa 2005, s. 130.

${ }^{9}$ S. Michalczyk, Komunikowanie polityczne..., dz. cyt., s. 196.

${ }^{10}$ W. Adamczyk, Skandal na pierwszej stronie. Sensacyjność jako element oceny wiarygodności śledztw dziennikarskich, w: M. Palczewski, M. Worsowicz (red.), O dziennikarstwie śledczym. Normy, zagrożenia, perspektywy, Łódź 2009, s. 28.
} 
karstwo śledcze to dotarcie możliwie jak najbliżej prawdy poprzez weryfikację informacji na ważny społecznie temat $w$ drodze dziennikarskiego dochodzenia - i przekazanie zgromadzonego tą drogą materiału opinii publicznej" ${ }^{11}$. Anna Marszałek uzupełnia powyższe definicje o niezwykle istotny element roli służb publicznych: „wyróżnia się ono niezależnością od ustaleń wszystkich innych, powołanych do tego organów, jak: policja, służby specjalne i wywołuje wymierny skutek w postaci wszczęcia śledztwa" ${ }^{12}$.

Analizując teksty śledcze, Monika Worsowicz kładzie nacisk na budowę i gatunek dziennikarski; tekst o charakterze śledczym jest to więc „publikacja prasowa o znacznej objętości, często skomplikowanej strukturze, niejednorodna pod względem gatunkowym; poświęcona ujawnieniu faktów mających istotny wpływ na życie publiczne, porządek społeczny publiczny i/lub prawny; jest efektem zazwyczaj długotrwałego, niejawnego ustalania przez dziennikarzy przebiegu zdarzeń (śledztwa) prowadzącego do publicznej kompromitacji osób, których szkodliwe działania zostały opisane w tekście; inicjuje publiczną dyskusję na dany temat oraz zapoczątkowuje - częściej - intensyfikuje działania organów ścigania w opisanej sprawie" ${ }^{13}$. Wydaje się, że autorka zawarła w tej definicji wszystkie cechy tekstu o charakterze śledczym.

Niektórzy praktycy twierdzą, iż dziennikarstwa śledczego nie należy odróżniać od dziennikarstwa w ogóle; że wypełnianie misji, tropienie nieprawidłowości i ujawnianie ich mieści się w definicji samego dziennikarstwa. Realizacja misji dziennikarskiej i funkcjonowanie w ramach czwartej władzy odnosi się przecież do dziennikarstwa w ogóle, choć często podkreślane jest w charakterystyce dziennikarstwa śledczego. Jednakże, trzeba zauważyć, że tekst dziennikarski o charakterze śledczym różni się znacząco typowego tekstu dziennikarskiego: ma nutę sensacyjności. W publikacji tej dziennikarz stawia zarzuty i publikuje dowody w postaci „zeznań” świadków, kopii dokumentów - co ma mobilizować opinię publiczną, a czasami także służby publiczne. Maciej Mrozowski twierdzi, iż dziennikarstwo śledcze, czyli „publikacje demaskujące wszelkiego rodzaju nadużycia i niegodziwość polityków" ${ }^{14}$, to rodzaj dziennikarstwa, który podnosi reputację samego dziennikarstwa, a gazety chętnie ujawniają patologie dotyczące polityków"15.

$\mathrm{Na}$ podstawie funkcjonujących w literaturze definicji dziennikarstwa śledczego można wyłonić następujące cechy publikacji śledczych:

- demaskowanie wszelkiego rodzaju nadużyć;

- niezależność ustaleń dziennikarza od pracy organów ścigania i innych służb;

- często dwie relacje: o wydarzeniach związanych z pewnymi faktami oraz o odkrywaniu prawdy na ten temat;

\footnotetext{
${ }^{11}$ B. Kittel, Dziennikarz z dymiącą strzelbą, w: A. Skworza, A. Niziołek (red.), Biblia dziennikarstwa, Kraków 2010, s. 110.

${ }^{12}$ I. Hofman, Polityka, media, społeczeństwo..., dz. cyt. s. 94-95.

${ }^{13}$ M. Worsowicz, Pragmatyka tekstów śledczych. Wybrane zagadnienia, w: M. Palczewski, M. Worsowicz (red.), Dziennikarstwo śledcze. Teoria..., dz. cyt., s. 123-124.

${ }^{14}$ M. Mrozowski, Media masowe. Władza, rozrywka i biznes, Warszawa 2001, s. 132-133.

${ }^{15}$ Tamże.
} 
- konwencja reportażu lub wywiadu, ułatwiająca lekturę;

- nadana tekstowi dramaturgia poprzez konfrontowanie ustaleń dziennikarza

z wypowiedziami bohaterów oraz relacjonowanie tego, co różne źródła mówią o tym samym fakcie.

$\mathrm{Z}$ wymienionych cech dwie wydają się być najważniejsze (bez nich tekst śledczy nie mógłby zaistnieć) - są to „demaskowanie nadużyć” oraz „, niezależność ustaleń od organów ścigania”.

Media regionalne i lokalne $\mathrm{w}$ dobie dominacji mediów elektronicznych borykają się z licznymi problemami. Znawcy tej tematyki wskazują na wiele negatywnych zmian z tym związanych, a nawet „pojawiają się hipotezy o zmierzchu czy wręcz końcu epoki mediów papierowych" ${ }^{\prime 16}$. Samo dziennikarstwo śledcze to także dziennikarstwo lokalne. Małgorzata Wyszyńska w artykule „Press” przybliżyła sylwetki pięciu dziennikarzy $\mathrm{z}$ różnych tygodników lokalnych, zajmujących się tropieniem patologii - stawiając przy tym tezę, że to właśnie w mediach lokalnych dziennikarstwo śledcze jest dobrze rozwinięte ${ }^{17}$. Czy jednak kilka pozytywnych przykładów żurnalistów jest w stanie zmienić panującą powszechnie opinię w świecie o mediach lokalnych jako tych, które są w recesji także jeśli chodzi o ujawnianie nadużyć i patologii? Czy przewidywany zmierzch mediów lokalnych, walka redakcji o przychylność miejscowych władz czy biznesów, uleganie oddziaływaniu reklamodawców, może iść w parze z demaskacją lokalnych „przekrętów"? W dalszej części artykułu zaprezentowane zostaną wyniki analizy empirycznej, która ma odpowiedzieć między innymi na tak postawione pytania.

\section{Cel i metodologia badań}

Intencją autorki było sprawdzenie, ile materiałów o charakterze demaskatorskim ukazało się w ciągu roku w największym dzienniku regionalnym w Polsce. Celem analizy zawartości „Dziennika Zachodniego” było określenie stopnia zainteresowania mediów lokalnych ujawnianiem nieprawidłowości, a także odpowiedź na pytanie, jak często dziennikarze podejmują trudne i kontrowersyjne tematy przybliżające społeczeństwu to, co ktoś chce ukryć. Analizę oparto na danych ilościowych, czyli liczbie tekstów będących wynikiem śledztwa dziennikarskiego. Analiza jakościowa miała dać odpowiedź na pytanie, kto jest przedmiotem zainteresowania dziennikarzy, ilu dziennikarzy publikuje teksty o charakterze śledczym, jaka jest powierzchnia tych tekstów względem innych materiałów dziennikarskich, a także jak wyeksponowane są te materiały i do jakiego gatunku dziennikarskiego należą.

Źródłem informacji był rocznik „Dziennika Zachodniego”, zawierający numery wydawane od 2 stycznia do 31 grudnia 2015 r. Łącznie były to 304 numery, w tym 248 pojedynczych, 53 podwójnych i 3 potrójne. Analizę przeprowadzono w październiku 2016 roku.

\footnotetext{
${ }^{16}$ M. Kornacka, Zmierzch prasy lokalnej? Ograniczenia w rozwoju prywatnych tytułów lokalnych na przykładzie Śląska Cieszyńskiego, w: W. Furman, P. Kuca (red.), Przemiany mediów regionalnych i lokalnych, Rzeszów 2015, s. 45.

${ }^{17}$ M. Wyszyńska, Lokalni tropiciele, „Press” nr 7-8.2016, s. 70-72.
} 
Wyboru tegoż dziennika dokonano nie bez powodu. „Dziennik Zachodni” wydawany jest od 1945 roku i jest największą gazetą regionalną w Polsce. Swym zasięgiem obejmuje 22 powiaty na terenie województwa śląskiego i małopolskiego. Wydawcą pisma jest spółka Polska Press Oddział Prasa Śląska. „Dziennik Zachodni” jest liderem w kategorii średniej sprzedaży wśród dzienników regionalnych i lokalnych (średnia sprzedaż „Dziennika Zachodniego” w styczniu 2015 roku wyniosła 45464 egzemplarzy - Wirtualne Media). Badania czytelnictwa przeprowadzone przez Millward Brown w okresie od stycznia do grudnia 2015 roku wskazują, że w województwie śląskim, w grupach wiekowych od 15 do 75 i od 16 do 59 lat, jest on najchętniej czytanym dziennikiem, a także liderem sprzedaży wśród dzienników regionalnych i lokalnych ${ }^{18}$.

\section{Dziennik Zachodni - wyniki analizy}

„Dziennik Zachodni” w 2015 roku zawierał od 16 do 52 stron, co daje średnią 28 stron w jednym numerze. Najwięcej wydano numerów 24 i 28-stronicowych.

\section{Tabela nr 1: Numery „Dziennika Zachodniego” w 2015 roku z liczbą stron}

\begin{tabular}{|c|c|}
\hline Liczba stron & Liczba numerów \\
\hline 16 & 19 \\
\hline 20 & 14 \\
\hline 22 & 1 \\
\hline 24 & 98 \\
\hline 26 & 4 \\
\hline 28 & 95 \\
\hline 30 & 1 \\
\hline 32 & 15 \\
\hline 36 & 17 \\
\hline 40 & 28 \\
\hline 44 & 10 \\
\hline 48 & 1 \\
\hline 52 & 1 \\
\hline ,Dzienniku Zachodnim” & 28 \\
\hline
\end{tabular}

Źródło: opracowanie własne.

${ }^{18}$ Duże zmiany w czytelnictwie dzienników w województwach,

http://www.wirtualnemedia.pl/artykul/duze-zmiany-w-czytelnictwie-dziennikow-w-wojewodztwach [data dostępu 10.12.2017];

„Fakt” nowym liderem w trzech regionach. Czytelnictwo dzienników w województwach,

http://www.wirtualnemedia.pl/artykul/fakt-nowym-liderem-w-trzech-regionach-czytelnictwo-

dziennikow-w-wojewodztwach [data dostępu 10.12.2017]; Czytelnictwo dzienników w województwach:

nowi liderzy w sześciu regionach, http://www.wirtualnemedia.pl/artykul/czytelnictwo-dziennikow-w-

wojewodztwach-nowi-liderzy-w-szesciu-regionach [data dostępu 10.12.2017]; Duże zmiany w regionalnym

czytelnictwie dzienników. Nowi liderzy w siedmiu województwach,

http://www.wirtualnemedia.pl/artykul/duze-zmiany-w-regionalnym-czytelnictwie-dziennikow-nowi-

liderzy-w-siedmiu-wojewodztwach/page:2 [data dostępu 10.12.2017]; Duże zmiany w czytelnictwie

dzienników w województwach. Siedem regionów z nowymi liderami,

http://www.wirtualnemedia.pl/artykul/duze-zmiany-w-czytelnictwie-dziennikow-w-wojewodztwach-

siedem-regionow-z-nowymi-liderami [data dostępu 10.12.2017]. 
Dokonano analizy 10032 publikacji z wyłączeniem artykułów sponsorowanych, reklam i ogłoszeń.

Wykres nr 1 .

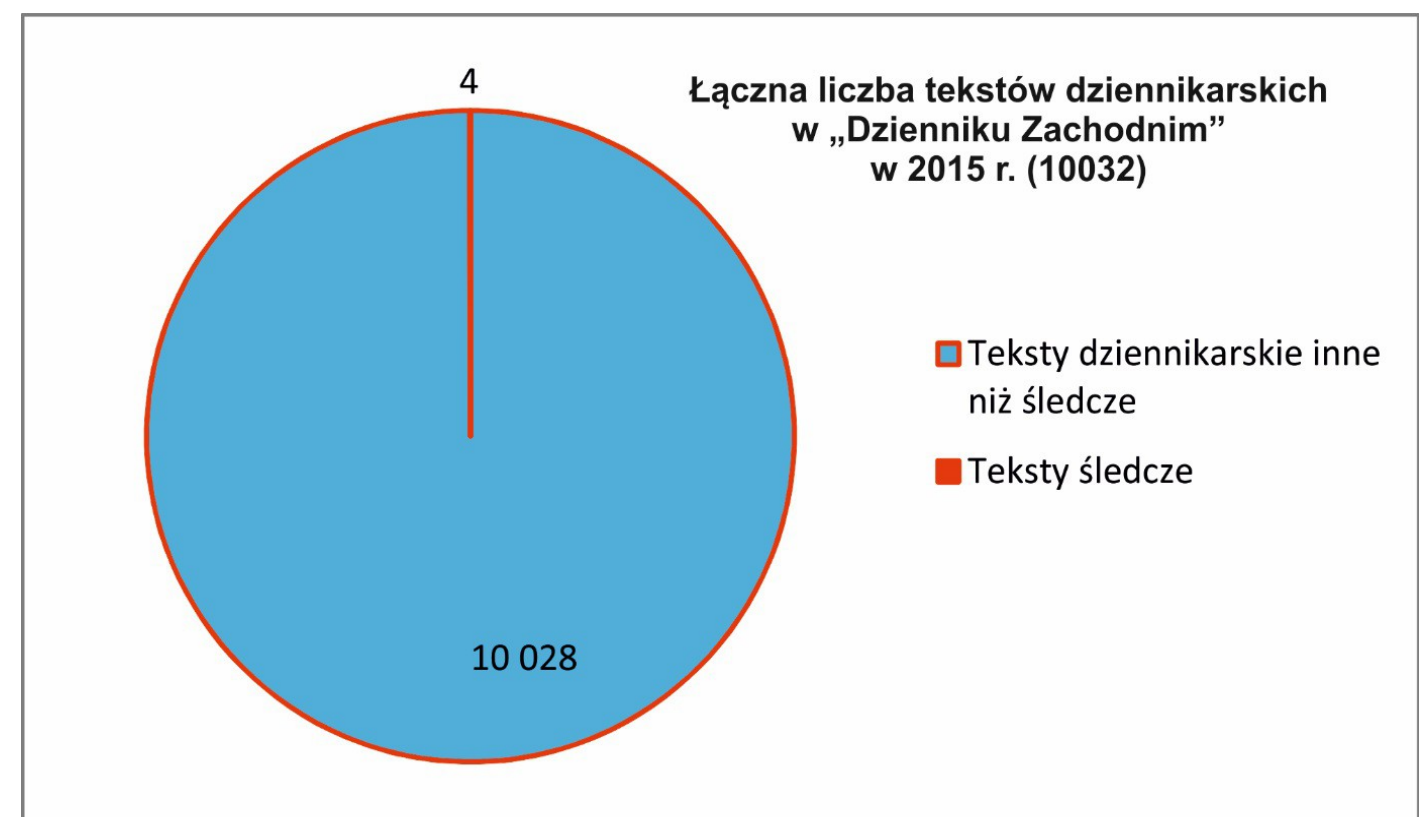

Źródło: opracowanie własne.

Przyjęto następujące kryteria klasyfikowania tekstów do dalszej analizy: posiadanie przez publikacje cech demaskatorskich, bycie niezależnymi wobec władz lokalnych, bycie istotnymi z punktu widzenia opinii publicznej. Spośród ponad 10 tys. tekstów stanowiących materiał badawczy, w trakcie analizy ilościowej wyłoniono tylko 4 teksty o charakterze śledczym (tabela $\mathrm{nr}$ 2). Trzy z nich („Wielkie interesy króla żylaków i białych zębów”, „Miał być cudowny lek. Są same kłopoty”, „Król białych zębów ma zarzut. Nie może wyjechać z Polski”) to cykl, w którym dziennikarze ujawniają kulisy interesów młodego biznesmena, który dorobił się majątku na handlu parafarmaceutykami. Produkty te, rzekomo zawierające nowe, wspaniałe receptury zachwalane przez lekarzy, okazały się substancjami o znanych i prostych składach, a polecający owe specyfiki lekarze w rzeczywistości nie mieli o nich pojęcia, albo zwyczajnie nie istnieli. W rezultacie pracy dziennikarzy cudotwórcza substancja na żylaki, a także pasta do zębów (sprzedawana w Anglii) okazują się być oszustwem, a sprawa znajduje swój finał w sądzie, o czym mówi ostatni z tekstów („Król białych zębów ma zarzut. Nie może wyjechać z Polski”). 
Tabela nr 2.

\begin{tabular}{|c|c|c|c|c|c|c|c|}
\hline Numer & Tytuł & Autor & Strona & Objętość & $\begin{array}{l}\text { Zapowiedź } \\
\text { na } 1 \text { stronie }\end{array}$ & Zakres tematyczny & $\begin{array}{l}\text { Źródła informacji } \\
\text { przed podjęciem } \\
\text { tematu }\end{array}$ \\
\hline 5-6.01.2015 & $\begin{array}{l}\text { "Migdałowy } \\
\text { dym", Powrót } \\
\text { dopalaczy" }\end{array}$ & $\begin{array}{l}\text { P. Ciastek } \\
\text { J. Strzelczyk }\end{array}$ & $10 / 32$ & $18 \times 19 \mathrm{~cm}$ & nie & $\begin{array}{l}\text { Ujawnienie nielegalnego } \\
\text { handlu dopalaczami }\end{array}$ & Brak danych \\
\hline 19.01.2015 & $\begin{array}{l}\text { „Wielkie } \\
\text { interesy króla } \\
\text { żylaków i } \\
\text { białych zębów” }\end{array}$ & M. Czerniak & $\begin{array}{l}18- \\
19 / 28\end{array}$ & $\begin{array}{l}29 \times 35 x \\
2 \text { strony }\end{array}$ & tak & $\begin{array}{l}\text { Ujawnienie nieuczciwych } \\
\text { praktyk w sprzedaży } \\
\text { parafarmaceutyków }\end{array}$ & Czytelnicy \\
\hline 20.01.2015 & $\begin{array}{l}\text { „Miał być } \\
\text { cudowny lek. Są } \\
\text { same kłopoty” }\end{array}$ & $\begin{array}{l}\text { M. Czerniak, } \\
\text { Ł. Cieśla }\end{array}$ & $11 / 28$ & $29 \times 35$ & nie & $\begin{array}{l}\text { Ujawnienie nieuczciwych } \\
\text { praktyk w sprzedaży } \\
\text { parafarmaceutyków }\end{array}$ & - \\
\hline 16.02 .2015 & $\begin{array}{l}\text { „Król białych } \\
\text { zębów ma } \\
\text { zarzut. Nie może } \\
\text { wyjechać z } \\
\text { Polski” }\end{array}$ & M. Czerniak & $14 / 28$ & $18 \times 15,5$ & nie & $\begin{array}{l}\text { Ujawnienie nieuczciwych } \\
\text { praktyk w sprzedaży } \\
\text { parafarmaceutyków }\end{array}$ & - \\
\hline
\end{tabular}

Źródło: opracowanie własne.

Natomiast publikacja „Migdałowy dym. Powrót dopalaczy” dotyczy ujawnienia nielegalnego handlu dopalaczami. Tym razem dziennikarze prowokują nielegalną sprzedaż: kupują dopalacze, posługując się zasłyszanym wcześniej hasłem „za 20”. W tym przypadku czytelnik nie dowiaduje się, jaki był ciąg dalszy nielegalnego procederu. Artykuł kończy się informacją o tym, że dopalacze projektowane są komputerowo i trudno z nimi walczyć, bo na rynek trafiają coraz to nowsze ich wersje, mające nowe składy chemiczne.

W obu przypadkach (materiał o dopalaczach oraz 3 artykuły dotyczące parafarmaceutyków) dziennikarze przeprowadzają swoje śledztwa w tzw. tandemie, która jest typową metodą w przypadku dziennikarskiej pracy śledczej: „W sprawach dochodzeniowych praca $w$ tandemie jest niemal regułą. Dziennikarze działają wtedy podobnie jak policjanci, którzy w terenie pracują we dwóch, ubezpieczając się nawzajem"19.

Wszystkie analizowane teksty opublikowano na początku roku 2015 i stanowią 0,042\% całości rocznika (wykres $\mathrm{nr} 2$ ). Uściślić należy, że wyliczenie procentowe dotyczy powierzchni udziału materiałów śledczych w „Dzienniku Zachodnim”, a więc w numerach, gdzie występowały teksty śledcze, zajmowały one od około $1 \%$ do ponad $7 \%$ powierzchni (wszystkich materiałów dziennikarskich), co obrazuje poniższy wykres. Wszystkie teksty śledcze, które udało się odnaleźć w trakcie analizy, dotyczyły biznesu: raczej małego, niż wielkiego.

\footnotetext{
${ }^{19} \mathrm{~J}$. Łęski, Źródła informacji i techniki pracy stosowane w dziennikarstwie dochodzeniowym. Uwagi warsztatowe, w: A. Hejman (red.), Poradnik dla wydawców i dziennikarzy prasy lokalnej, tom 3, Warszawa 1998, s. 213.
} 
Wykres nr 2

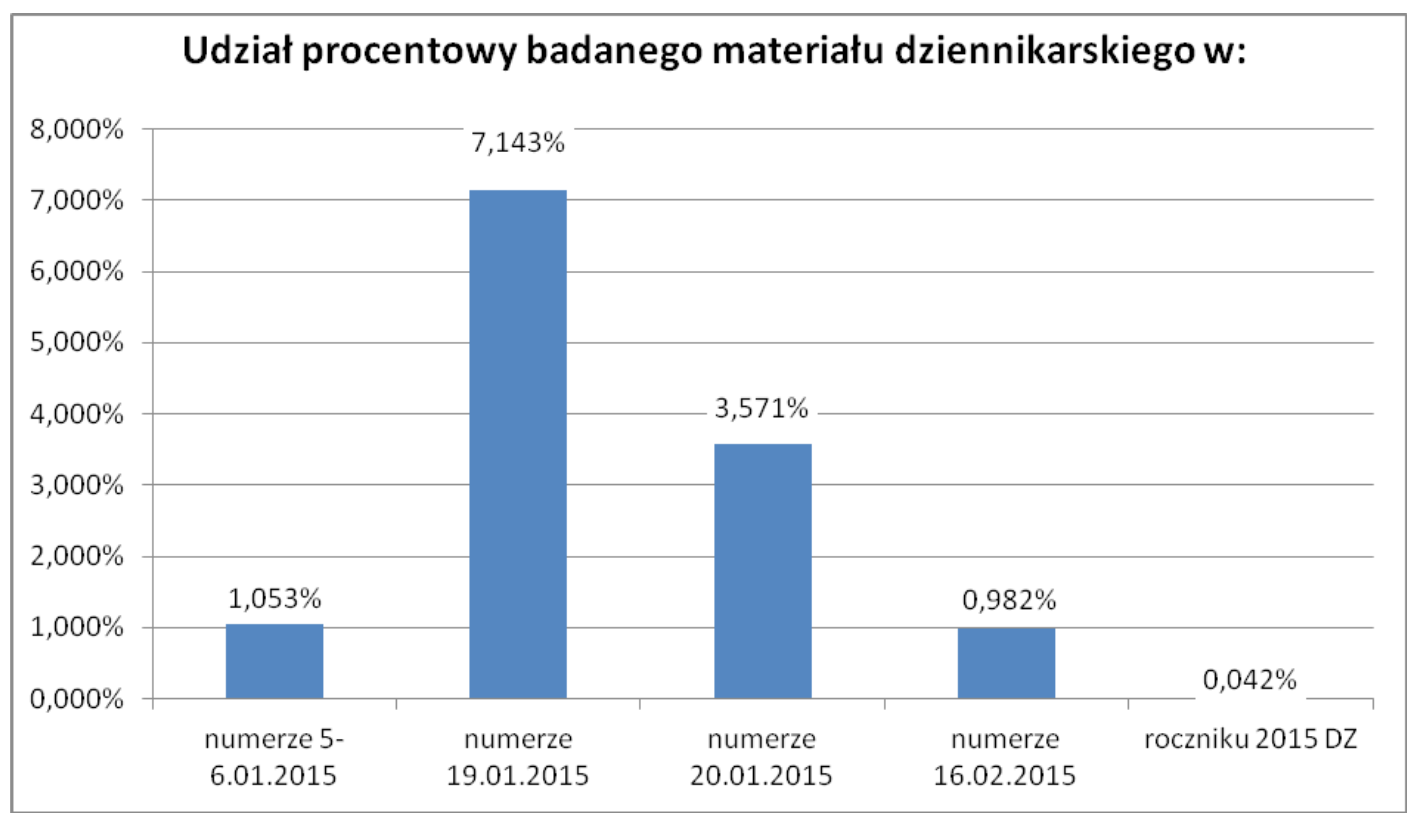

Źródło: opracowanie własne.

Publikacja tekstu śledczego w danym numerze stanowi dla redakcji ważny dzień, zwane w żargonie „wodowaniem”. W napięciu oczekuje się reakcji opinii publicznej, a także innych dziennikarzy. Istotą takiego tekstu jest przecież zainicjowanie dyskusji publicznej, a jeśli sprawa tego wymaga, również akceleracja działań organów ścigania. Wcześniej w redakcji pracuje się nad tym, by odpowiednio wyeksponować tekst w ramach pisma. Elementem, który potwierdza doniosłość publikacji w prasie, jest ekspozycja na okładce jego zapowiedzi, odpowiednia ekspozycja nadtytułów, tytułów i lidów. Wśród analizowanych materiałów tylko jeden z tekstów miał zapowiedź na okładce („Wielkie interesy króla żylaków i białych zębów”), zajmował 2 strony (wymiar gazety: 29x55cm), czyli 12 szpalt, i opatrzony został grafikami. Dwie publikacje („Migdałowy dym. Powrót dopalaczy”, „Miał być cudowny lek. Są same kłopoty”) miały po jednej nawiązującej do tematu tekstu fotografii, przy czym jedna z nich była tylko relacją ze śledztwa policyjnego, bez grafik („Król białych zębów ma zarzut. Nie może wyjechać z Polski”).

Sytuacja lub sytuacje, które bywają przedmiotem dziennikarskiego śledztwa, są zazwyczaj skomplikowane i wielowątkowe. Jeśli taki tekst zostanie nieumiejętnie zaprezentowany, czytelnik może mieć wrażenie chaosu. Nie sprzyja także przejrzystości w tekście śledczym konwencja reportażowa $\mathrm{z}$ dwiema relacjami o wydarzeniach oraz o odkrywaniu prawdy na ten temat. Zaleca się zatem „wzbogacenie tekstu (...) o elementy, które 
ułatwiają jego zrozumienie i interpretację, jak: ikonografiki wizualizujące kolejne etapy rozwoju śledztwa lub działania bohaterów, krótkie sylwetki postaci, zestawienia najważniejszych tez konfliktu czy kalendaria zdarzeń". ${ }^{20}$

Analiza ekspozycji tytułów wykazała, że tylko jeden z tekstów, a więc „Wielkie interesy króla żylaków i białych zębów”, miał zapowiedź na okładce, nadtytuł „nasze śledztwo” oraz lid. Pozostałe teksty nie miały zapowiedzi na okładce, a „Migdałowy dym. Powrót dopalaczy" nawet nadtytułu (tabela nr 3).

Tabela nr 3: Tytuły analizowanych tekstów

\begin{tabular}{|c|c|c|c|c|}
\hline Nadtytuł & Brak & Nasze śledztwo & $\begin{array}{l}\text { Dziennikarskie } \\
\text { śledztwo }\end{array}$ & Śledztwo \\
\hline lytuk & $\begin{array}{l}\text { "Migdałowy dym", } \\
\text { Powrót dopalaczy" }\end{array}$ & $\begin{array}{l}\text { „Wielkie interesy króla } \\
\text { żylaków i białych } \\
\text { zębów" }\end{array}$ & $\begin{array}{l}\text { "Miał być cudowny lek. } \\
\text { Są same kłopoty" }\end{array}$ & $\begin{array}{l}\text { „Król białych zębów ma } \\
\text { zarzut. Nie może } \\
\text { wyjechać z Polski” }\end{array}$ \\
\hline Lid & $\begin{array}{l}\text { W małym sklepie z } \\
\text { „pamiątkami” klienci to } \\
\text { nastolatki, kupujące } \\
\text { susz w małych } \\
\text { torebkach. Wg. } \\
\text { instrukcji, do } \\
\text { dosypywania do } \\
\text { kominka. }\end{array}$ & $\begin{array}{l}\text { Zasłynął jako } \\
\text { najmłodszy w Polsce } \\
\text { założyciel prywatnej } \\
\text { kliniki, Gdy interes } \\
\text { padł, Krzysztof } \\
\text { Mazurski przestał być } \\
\text { pupilkiem mediów. } \\
\text { Dziś 22-letni } \\
\text { biznesmen więcej } \\
\text { czasu spędza nad } \\
\text { Atlantykiem niż w } \\
\text { Polsce. Czy dlatego, że } \\
\text { tu grunt zaczyna się } \\
\text { mu palić pod stopami? }\end{array}$ & $\begin{array}{l}\text { Za kampanią } \\
\text { reklamową, m.in. } \\
\text { kontrowersyjnej maści } \\
\text { na żylaki, stoi } \\
\text { „wschodząca gwiazda } \\
\text { biznesu”. Wielu } \\
\text { klientów sygnalizuje } \\
\text { nam, że zostali } \\
\text { oszukani. Policja na } \\
\text { razie próbuje } \\
\text { bagatelizować sprawę. }\end{array}$ & $\begin{array}{l}\text { Piotr K. nazwany } \\
\text { najmłodszym polskim } \\
\text { milionerem, ma dwa } \\
\text { lata więzienia. O jego } \\
\text { interesach pisaliśmy w } \\
\text { styczniu. }\end{array}$ \\
\hline
\end{tabular}

Źródło: opracowanie własne.

Jak uważa Cezary Gmyz, w dziennikarstwie śledczym istnieje święta zasada „o źródłach jak najmniej a najlepiej w ogóle.”21. Czasami dziennikarz śledczy wspomina lakonicznie, że informacje posiada np. z „kręgów władzy” czy od czytelników. W przypadku analizowanych tekstów tylko w jednym przypadku (tabela $\mathrm{nr}$ 2) autorzy wskazali na czytelników (,Wielkie interesy króla żylaków i białych zębów”).

Ostatnim analizowanym zagadnieniem był gatunek dziennikarski, jakim posługiwali się autorzy badanych tekstów. W przypadku publikacji o charakterze śledczym bardzo trudno przypisać im gatunek ze względu na ich niejednorodność, co sygnalizuje Monika Worsowicz ${ }^{22}$. „Migdałowy dym. Powrót dopalaczy” jest sprawozdaniem, a więc rodzajem gatunku informacyjnego: to relacja oparta na faktach. Autorzy przedstawiają wydarzenia w sposób dynamiczny, w porządku czasowym. Fakty są przedstawione

\footnotetext{
${ }^{20}$ M. Worsowicz, Pragmatyka tekstów śledczych..., dz. cyt., s. 132.

${ }^{21}$ C. Gmyz, Zawód: dziennikarz śledczy, Warszawa 2013, s. 15.

${ }^{22}$ M. Worsowicz, Pragmatyka tekstów śledczych..., dz. cyt., s. 123.
} 
szczegółowo, a tekst ma postać dłuższej informacji. Tekst „Wielkie interesy króla żylaków i białych zębów" uznać można za reportaż problemowy. Przemawia za tym fakt, że autor występuje w kilku rolach: jest obserwatorem, sprawozdawcą i sędzią. Autor przedstawia fakty, a także relacje innych osób; wysuwa tezy, argumentuje i wnioskuje. Z kolei artykuł „Miał być cudowny lek. Są same kłopoty” jest kontynuacją poprzedniego materiału i także możemy zaliczyć go do reportażu problemowego (publicystycznego), ponieważ wykazuje większość cech tego gatunku. W trzeciej i ostatniej publikacji cyklu pt. „Król białych zębów ma zarzut. Nie może wyjechać z Polski”, autor zastosował odmianę sprawozdania - raport, jeden z gatunków informacyjnych. O przynależności do tego gatunku może świadczyć chronologiczne przywołanie faktów oraz krótki opis wydarzeń i bohatera.

Jak więc widać, teksty, które w wyniku analizy zostały poddane badaniu, nie wykazują jednorodności gatunkowej.

\section{Wnioski i podsumowanie}

Badaniu poddany został rocznik „Dziennika Zachodniego”, czyli 304 numery pisma. Analiza wykazała, że spośród 10032 artykułów tylko 4 można określić jako materiały dziennikarskie o charakterze śledczym. Stanowią one zaledwie $0,042 \%$ powierzchni wszystkich tekstów dziennikarskich.

Wszystkie te teksty odnoszą się do biznesu i działań nieetycznych lub przestępczych. Ich autorami było 4 dziennikarzy pracujących w „tandemach”. Autorzy zastosowali w dwóch przypadkach konwencję reportażu publicystycznego, w jednym odmianę sprawozdania - raport, a w jeszcze innym gatunek informacyjny - sprawozdanie, relację opartą na faktach. Na tej podstawie nie można stwierdzić jednorodności gatunkowej tych tekstów czy istnienia określonego gatunku „reportażu śledczego”.

W badanych artykułach mocno zaznaczała się również tendencja do społecznego piętnowania i negatywnego oceniania działań ich bohaterów - przedstawicieli biznesu.

Znikomy udział dziennikarstwa śledczego w prasie regionalnej ma wiele potencjalnych przyczyn. Może być spowodowany uzależnieniem redakcji od obcego kapitału (w przypadku wydawcy DZ - Polska Press - chodzi o kapitał niemiecki) i zabieganiem o przychylność miejscowych władz. Media lokalne i regionalne są też zależne od reklamodawców - co kłóci się z tropieniem nieprawidłowości w małych i dużych firmach przez dziennikarzy śledczych. Jeszcze innym powodem, wskazywanym często w literaturze, jest niechęć zarządzających do żmudnej, dziennikarskiej pracy, bez szybkich efektów, a często także ich nie gwarantującej. Stąd, częściej możemy zobaczyć materiały, które „udają” tylko materiały śledcze, a w istocie są tekstami interwencyjnymi, relacjami z działań organów ścigania lub innych służb publicznych. Powodem nie mniej częstym jest także lęk przed konsekwencjami prawnymi i finansowymi. Sprawy o zniesławienie oraz naruszenie dóbr osobistych i wynikające z nich wysokie odszkodowania trwale zniechęcają właścicieli wydawnictw do publikacji tekstów, które mogą naruszać czyjąś cześć. Dziś niemal każdy dziennikarz zajmujący się dziennikarstwem śledczym ma na 


\section{OBLICZA MEDIÓW I KOMUNIKACJI}

swym koncie udział w rozprawie sądowej, gdzie oskarża się go o zniesławienie i żąda odszkodowania od macierzystej redakcji. Sytuacja finansowa mediów lokalnych jest trudna, a obciążenie finansowe w postaci odszkodowania może spowodować, że tytuł zniknie na zawsze z mapy mediów.

Odpowiedź na pytanie o przyczyny tak skromnej liczby tekstów o charakterze śledczym w analizowanym „Dzienniku Zachodnim” wymaga dalszych dociekań, w których pomocne byłyby pogłębione wywiady z dziennikarzami, połączone $\mathrm{z}$ ankietą. Wyniki tych dociekań z pewnością pozwoliłyby odpowiedzieć na pytanie, dlaczego w dzienniku o tak dużym zasięgu nie podejmuje się trudnych tematów.

\section{BIBLIOGRAFIA}

Adamczyk W., Rzecz o kontynuacji: amerykańskie wzorce investigative reporting w praktyce polskich reporterów śledczych, w: M. Palczewski, M. Worsowicz, News i dziennikarstwo śledcze wobec wyzwań XXI wieku, Łódź 2010.

Adamczyk W., Skandal na pierwszej stronie. Sensacyjność jako element oceny wiarygodności śledztw dziennikarskich, w: M. Palczewski, M. Worsowicz (red.), O dziennikarstwie śledczym. Normy, zagrożenia, perspektywy, Łódź 2009.

Adamczyk W., Ujawnianie korupcji i nadużyć władzy w działalności amerykańskich muckrakerów, w: red. M. Palczewski, M. Worsowicz, Dziennikarstwo śledcze. Teoria i praktyka w Polsce, Europie i Stanach Zjednoczonych, Łódź 2006.

Braun J., Potęga czwartej władzy, Warszawa 2005.

Brzoza K., Rola Dziennika Zachodniego w wyborach samorządowych 2014, w: S. Michalczyk, D. Krawczyk (red.), Oblicza mediów lokalnych i regionalnych, Mikołów 2016.

Goban-Klas T., Dziennikarstwo śledcze w USA. Powstanie, rozkwit, rozkład, w: red. M. Palczewski, M. Worsowicz, Dziennikarstwo śledcze. Teoria i praktyka w Polsce, Europie i Stanach Zjednoczonych, Łódź 2006.

Hofman I., Polityka, media, społeczeństwo. Studia i szkice, Toruń 2007.

Kittel B., Dziennikarz z dymiącą strzelbą, w: A. Skworza, A. Niziołek (red.), Biblia dziennikarstwa, Kraków 2010.

Kornacka M., Zmierz prasy lokalnej? Ograniczenia w rozwoju prywatnych tytułów lokalnych na przykładzie Śląska Cieszyńskiego, w: W Furman, P. Kuca (red.), Przemiany mediów regionalnych i lokalnych, Rzeszów 2015.

Kowalczyk R., Media lokalne w Polsce. Podręcznik akademicki, Poznań 2009. 
Łęski J., Źródła informacji i techniki prascy stosowane w dziennikarstwie dochodzeniowym. Uwagi warsztatowe, w: A. Hejman (red.), Poradnik dla wydawców i dziennikarzy prasy lokalnej, tom 3, Warszawa 1998.

Michalczyk S., Komunikowanie polityczne. Teoretyczne aspekty procesu, Katowice 2005.

Mrozowski M. Media masowe. Władza, rozrywka i biznes, Warszawa 2001.

Worsowicz M, Reportaż, artykuł i... - charakterystyka genologiczna prasowych tekstów śledczych, w: M. Palczewski, M. Worsowicz (red.), O dziennikarstwie śledczym. Normy, zagrożenia, perspektywy, Łódź 2009.

Worsowicz M, Pragmatyka tekstów śledczych. Wybrane zagadnienia, w: tenże (red.), Dziennikarstwo śledcze. Teoria i praktyka w Polsce, Europie i Stanach Zjednoczonych, Łódź 2006.

Wyszyńska M., Lokalni tropiciele, „Press” nr 7-8, 2016.

\section{ŹRÓDŁA INTERNETOWE}

www.wirtualnemedia.pl

www.freedomhouse.org

\section{OAUTORCE:}

mgr Karolina Polinska - absolwentka politologii i dziennikarstwa na Wydziale Nauk Społecznych Uniwersytetu Śląskiego, doktorantka stacjonarnych Studiów Doktoranckich Nauki o Polityce, Instytutu Nauk Politycznych i Dziennikarstwa, Uniwersytetu Śląskiego Zakład Komunikacji Społecznej. Pod kierunkiem prof. dr hab. S. Michalczyka przygotowuje dysertację doktorską na temat dziennikarskich materiałów śledczych i ich wpływu na komunikowanie polityczne.Kontakt: ka.polinska@wp.pl 
кuLTura- MeDia- TeoLogia

ISSN 2081-8971

$2017 \mathrm{nr} 30$, s. 151-160.

\section{Millenialsi i ich „tele-wizje”. Geneza i konstrukcja programu badawczego}

\section{Millenials and their „tele-visions”. Genesis and construction of a research programme.}

\begin{abstract}
STRESZCZENIE:
ARTYKUŁ STANOWI PREZENTACJE PROJEKTU BADANIA POD NAZWĄ ,TELEWIZJA TRADYCYJNA, ON-LINE I SPOŁECZNOŚCIOWA JAKO NARZĘDZIE EDUKOWANIA POKOLENIA Y”. PRZEDSTAWIONO PUNKT WYJŚCIA DO BADAŃ NA TEMAT SZEROKO ROZUMIANEGO KONSUMOWANIA TELEWIZJI WŚRÓD PRZEDSTAWICIELI POKOLENIA TZW. „MILLENIALSÓW”. CZĘŚĆ TEORETYCZNA DOTYCZY PROBLEMATYKI

WSPÓŁCZESNEGO KOMUNIKOWANIA SPOŁECZNEGO W NAWIĄZANIU DO EDUKACJI MEDIALNEJ. DRUGA CZĘŚĆ ZAWIERA PREZENTACJĘ NARZĘDZIA BADAWCZEGO, TJ. ANKIETY OPRACOWANEJ W RAMACH PROJEKTU, KTÓRY DOTYCZYŁ RÓŻNYCH FORM ODBIORU TELEWIZJI PRZEZ

PRZEDSTAWICIELI POKOLENIA Y. AUTOR OPISUJE RÓWNIEŻ PRZEBIEG TEGO BADANIA WŚRÓD STUDENTÓW DZIENNIKARSTWA UNIWERSYTETU KARDYNAŁA STEFANA

WYSZYŃSKIEGO I UNIWERSYTETU WARSZAWSKIEGO.

NAJWAŻNIEJSZE WYNIKI ANKIETY POZWALAJĄ SFORMUŁOWAĆ KOLEJNE PYTANIA BADAWCZE ZWIĄZANE Z POTRZEBAMI, MOTYWACJA, OCZEKIWANIAMI I NAWYKAMI „MILLENIALSÓW”.
\end{abstract}

\section{SŁOWA KLUCZOWE:}

TELEWIZJA, POKOLENIE Y, MILLENIALSI, EDUKACJA MEDIALNA, INTERNET

\begin{abstract}
:
THE ARTICLE FORMS A PRESENTATION OF A PREPARATION TO CONDUCT A RESEARCH PROJECT, TITLED “TRADITIONAL, On-Line And Social Television As A Tool For GENERATION Y EDUCATION”. AN ENTRY POINT TO RESEARCH ON BROADLY-UNDERSTOOD TV CONSUMPTION AMONG MILLENIALS HAS BEEN SHOWN. THE THEORETICAL PART COVERS CONTEMPORARY MASS COMMUNICATION IN RELATION TO MEDia EDUCATION. PART TWO IS A PRESENTATION OF A RESEARCH TOOL, I.E. A SURVEY CONSTRUCTED DURING THE COURSE OF A PROJECT ON TV RECEPTION FORMS BY THE GENERATION Y. IT ALSO SHOWS ITS PROGRESSION AMONG THE JOURNALISM STUDENTS OF CARDINAL WyszYŃSKI UniverSITY AND WARSAW UNIVERSITY. THE KEY SURVEY RESULTS JUSTIFY CONSTRUCTION OF FOLLOW-UP QUESTIONS RELATED WITH NEEDS, MOTIVATION, EXPECTATIONS AND HABITS OF Millenials.
\end{abstract}

\section{KEYWORDS:}

Television, Generation Y, Millenials, Media

EDUCATION, The INTERNET 
$\mathbf{P}$ roces tworzenia i wykorzystywania kanałów dystrybucji, powstających na bazie technologii mobilnych dla wyprodukowanych przez media treści, w znacznym stopniu przyczynił się do zmiany oblicza współczesnych mediów. Internet stał się kluczową platformą w zakresie komunikowania masowego, a dotychczasowe, nazywane też tradycyjnymi, sposoby nadawania, nie są dla nowych pokoleń odbiorców kanałami atrakcyjnymi. Dzieje się tak ze względu na ograniczenia ilościowe oferty, zasięg, a także niewielką, w stosunku do mediów internetowych, możliwość wpływu na kształt i treść wybieranych przekazów.

W celu przeprowadzenia wstępnej weryfikacji tez, związanych z konsumpcją mediów audiowizualnych wśród studentów kierunków dziennikarskich dwóch warszawskich uczelni - Uniwersytetu Warszawskiego i Uniwersytetu Kardynała Stefana Wyszyńskiego, opracowane zostały pilotażowe badania pt. „Telewizja tradycyjna, on-line i społecznościowa jako narzędzie edukowania pokolenia Y”. Badaniem zostali objęci tylko ci studenci, którzy przynależą do tzw. pokolenia $\mathrm{Y}^{1}$. Cele poznawcze badania, do przeprowadzenia którego zostało stworzone narzędzie w formie ankiety on-line, obejmowały m.in.: badanie sposobów konsumowania telewizji przez przedstawicieli pokolenia $\mathrm{Y}$, wyjaśnienie czynników wpływających na sposób konsumowania telewizji, preferowanych audycji telewizyjnych, poszukiwanych treści czy źródeł wiedzy na temat audycji telewizyjnych. Zakładano, że projektowane badanie powinno przynieść odpowiedzi na stawiane pytania badawcze, m.in jak i w jakim stopniu przedstawiciele pokolenie $Y$ konsumują telewizję tradycyjną, a także co wpływa na wzrost lub zmniejszenie zainteresowania telewizją, jakie nawyki/zwyczaje konsumowania różnych gatunków telewizyjnych możemy zaobserwować?

Jednak zarówno w trakcie rozmów przed wykonaniem badania, jak i podczas spotkań briefingowych zespołu badawczego ${ }^{2}$ oraz po wykonaniu samego badania, pojawiło się wiele dodatkowych pytań. Większość z nich przedstawiono w poniższym opracowaniu. Dotyczyły one zarówno edukacji medialnej, pokolenia Y, edukowania konsumentów, mediów społecznościowych, jak i postaw społecznych. Projekt powyższego badania zakładał, że wyniki, przynajmniej w części dotyczącej telewizji jako narzędzia edukowania, przyniosą odpowiedzi stanowiące punkt wyjścia do dalszych badań.

\section{Geneza badań odbioru telewizji wśród przedstawicieli pokolenia Y}

Pomysł na przeprowadzenie ankiety zrodził się $\mathrm{w}$ trakcie zajęć prowadzonych przez pracowników Instytutu Edukacji Medialnej i Dziennikarstwa UKSW. Podczas ćwiczeń z przedmiotów obejmujących swym programem zagadnienia związane z public relations, marketingiem medialnym czy promocją, zauważono istotne, charakterystyczne

\footnotetext{
${ }^{1}$ W literaturze naukowej brak jednoznacznych granic wiekowych, oznaczających przynależność do pokolenia Y (również: pokolenie Millenium, millenialsi, generacja Why). Umownie określa się tak pokolenie osób urodzonych w latach 1980-2000.

${ }^{2}$ Zespół tworzyli przedstawiciele Instytutu Edukacji Medialnej i Dziennikarstwa UKSW oraz Laboratorium Badań Medioznawczych UW. Prace nad przygotowaniem badania rozpoczęto w marcu 2017.
} 
dla pokolenia Y, postawy w podejściu do konsumowania telewizji, zwłaszcza w jej tradycyjnej, tzw. linearnej formie ${ }^{3}$. Odejście od znanej od dziesięcioleci formuły oglądania telewizji stało się faktem, zmiany te były widoczne również w postawach studentów kierunków dziennikarskich. Uwidaczniały się one zwłaszcza w trakcie dyskusji, ale także w czasie grupowych i indywidualnych zadań, przedmiotem których były przekazy telewizyjne. W zgodnej opinii prowadzących zajęcia zjawisko to było znaczące i niosło ze sobą potencjał badawczy. Bardzo duże znaczenie przy podejmowaniu decyzji o zbadaniu postaw studentów, miało podejście pracowników Instytutu Edukacji Medialnej i Dziennikarstwa UKSW do jak najlepszego opracowania programów nauczania.

Dobrze obrazuje to przykład z przedmiotu „Zintegrowany marketing medialny”, realizowanego na I roku studiów na kierunku „Dziennikarstwo i komunikacja społeczna" UKSW, w roku akademickim 2016/17. W trakcie zajęć omawiano aktualne programy rozrywkowe, emitowane w ogólnodostępnych kanałach telewizyjnych. W kolejności były to: „Agent Gwiazdy” (TVN), „Kuba Wojewódzki” (TVN) oraz festiwal „Eurowizja” (TVP). W ćwiczeniach uczestniczyły cztery grupy studentów, łącznie ok. 110 osób. Większość z nich, pytana o program, jego zasady, uczestników, historię czy zwycięzców, potrafiła wskazać istotne wątki. Jednocześnie jedynie niespełna 10 osób spośród wszystkich, którym stawiano pytanie, przyznała się do oglądania ww. programów w telewizji tradycyjnej. Skąd zatem pozostałe osoby (ok. 100) miały wiedzę na temat omawianych programów? Informacje czerpały z transmisji bądź relacji dostępnych w Internecie, mediach społecznościowych lub VOD ${ }^{4}$. Uznano, że przytoczony powyżej przypadek mógł stanowić punkt wyjścia dla badań jakościowych i ilościowych.

Podjęta inicjatywa związana jest także z edukacją medialną ${ }^{5}$, a więc również z zadaniami, jakie stawia ona przed prowadzącymi zajęcia dydaktyczne. Według Jana Jaroszyńskiego, edukacja medialna polega „(...) na kształceniu w dziedzinie narzędzi komunikowania społecznego w celu zrozumienia ich natury, oddziaływania oraz efektywnego wykorzystania. Dzięki takiemu podejściu odbiorcy są wszechstronnie przygotowani do posługiwania się mediami, przybierając właściwe postawy" ${ }^{6}$.Zatem, właściwe poznanie świata odbiorców mediów, w tym wypadku telewizji, wydaje się być fundamentalne $\mathrm{w}$ procesie tworzenia programu zajęć z wybranych przedmiotów (ćwiczeń) prowadzonych w toku studiów dziennikarskich.

W tym miejscu warto na chwilę zatrzymać się przy ogólnej charakterystyce „millenialsów”, nie tylko jako studentów. Jest to pierwsze, liczące już ok. 9 milionów pokolenie, które dorastało w warunkach gospodarki rynkowej. Oceniane jako wykształcone,

\footnotetext{
${ }^{3}$ Linearny sposób nadawania programów ujęty jest w tzw. ramówkę, w której stacja telewizyjna określa kolejność nadawanych programów i godziny emisji.

${ }^{4}$ Ang. Video On Demand, video na żądanie - usługa która umożliwia oglądanie filmu lub programu (także nadawanego na żywo) w czasie wybranym przez odbiorcę (późniejszym od emisji).

5 „Edukację medialną możemy definiować jako wychowanie do korzystania z mediów”, cyt. za: P. Drzewiecki, Edukacja medialna a nauczanie religii w szkole, Warszawa 2013, s. 27.

${ }^{6}$ J. Jaroszyński, Sport jako wyzwanie dla edukacji medialnej, w: M. Jarosz, P. Drzewiecki, P. Płatek (red.), Sport w mediach, Warszawa 2013, s. 257-258.
} 
świadome i pewne siebie, ale także egoistyczne, roszczeniowe i nielojalne - zwłaszcza wobec pracodawców, gdyż w przeciwieństwie do przedstawicieli pokolenia $\mathrm{X}^{7}$, nie boją się zmian miejsca pracy i mają wobec niej określone wymagania, czasem trudne do zaakceptowania przez firmy przyzwyczajone do dyktowania warunków zatrudnienia. W odróżnieniu od wcześniejszych pokoleń, dla pokolenia Y ważne jest zachowanie zasady work-life-balance ${ }^{8}$. Zatem nic dziwnego, że pomiędzy przedstawicielami pokoleń, zwłaszcza w relacji zwierzchnik-podwładny, dochodzi do nieporozumień, których źródłem często bywa właśnie konflikt wartości. Sylwia Radzięta z firmy Sedlak\&Sedlak, zajmującej się doradztwem personalnym i analizami rynku pracy, w ten sposób ujmuje charakterystyczne dla „millenialsów” podejście do rynku pracy: „Ludzie tego pokolenia nie mieli do czynienia z masowymi zwolnieniami, nie wiedzą co to stan wojenny, nigdy nie stali w kilometrowych kolejkach do sklepów, w których de facto nic nie można było nabyć. Samochód, komórka, laptop to dobra powszechnie dostępne. Wszelkie te uwarunkowania doprowadziły do tego, że ludzie młodzi nastawieni są roszczeniowo do świata, wydają się być mało zapobiegliwi i niecierpliwi. Pokolenie Y cechuje się zupełnie innymi wartościami, niż ludzie starsi urodzeni przed rokiem 1960"9.

Decyzje zakupowe podejmowane przez typowego przedstawiciela pokolenia Y sa zgoła odmienne od tych, na których opierały swoje postępowanie poprzednie pokolenia. „Z punktu widzenia marek, najważniejszym wyróżnikiem tego pokolenia jest brak chęci posiadania. Millenialsi nie odczuwają potrzeby kupna mieszkania, czy samochodu. Zamiast tego preferują wynajem. Korzystają z Ubera lub przesiadają się na wynajęty rower. (...) Rodzi to oczywiste wyzwanie dla producentów wszelkiego rodzaju dóbr osobistych i usług - jak bowiem przekonać millenialsa, że warto kupić oferowany przez nich produkt lub usługę?” - czytamy w opracowaniu Kazimierza Stańczaka ${ }^{10}$ dla magazynu „Forbes”11. Obserwując kampanie znanych marek z sektora finansowego, można zauważyć trend, który zmienia dotychczas stosowaną taktykę. Przyjmując, że grupa docelowa nie jest zainteresowana braniem kredytów na cele długoterminowe (budowa domu, zakup samochodu), które dotąd były wiodącymi produktami w ofercie banków, propozycje kieruje się biorąc pod uwagę zainteresowania potencjalnych klientów. W przypadku „millenialsów” mogą to być na przykład podróże.

\footnotetext{
${ }^{7}$ Pokolenie osób urodzonych w drugiej połowie XX wieku, jednak definitywne granice nie zostały ustalone. W opracowaniach naukowych najczęściej wymienia się lata 1965-1980.

${ }^{8}$ Koncepcja równowagi pomiędzy życiem zawodowym a prywatnym, powstała w latach 80 . XX wieku w USA. Za: W. Leoński, Work - Life Balance jako praktyka koncepcji społecznej odpowiedzialności biznesu, data publ. 23.07.2015, http://apcz.umk.pl/czasopisma/index.php/AUNC_ZARZ/article/viewFile/AUNC_ZARZ.2015.010/7152 (dostęp: 19.11.2017).

${ }^{9}$ S. Radzięta, Czego spodziewać się po pokoleniu Y?, data publ. 22.09.2014, https://rynekpracy.pl/artykul.php/typ.1/kategoria_glowna.324/wpis.826, (dostęp: 09.09.2017).

${ }^{10}$ Kazimierz Stańczak - Wydział Ekonomii University of Rochester w USA, były prezes zarządu Polbank EFG i wiceprezes zarządu banku Raiffeisen Polbank.

${ }^{11}$ K. Stańczak, Jak sprzedawać tym, którzy nie mają potrzeby posiadania?, data publ. 18.07.2016, https://www.forbes.pl/opinie/millenialsi-pokolenie-y/lfbx6sg, (dostęp: 07.09.2017).
} 


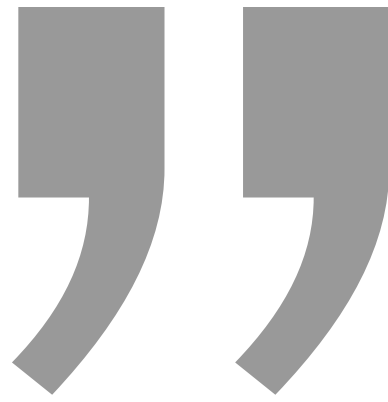

Obserwując kampanie znanych marek z sektora finansowego, można zauważyć trend, który zmienia dotychczas stosowaną taktykę. Przyjmując, że grupa docelowa nie jest zainteresowana braniem kredytów na cele długoterminowe (budowa domu, zakup samochodu), które dotąd były wiodącymi produktami w ofercie banków, propozycje kieruje się biorąc pod uwagę zainteresowania potencjalnych klientów. W przypadku „millenialsów” moǵą to być na przykład podróże.

Pewnemu przewartościowaniu ulega także tradycja marki. Do niedawna potężna broń podczas określania strategii komunikacji, dziś bywa traktowana drugoplanowo, bądź w niektórych wypadkach zupełnie pomijana. Trafnie zauważa to ponownie Kazimierz Stańczak, pisząc: „Na przykład Apple to nie producent nowoczesnych telefonów, ale symbol przynależności społecznej. Noszenie ubrań Adidasa czy Nike’a to nie wygoda i komfort, ale demonstracja stylu życia. Te marki doskonale zdają sobie sprawę, jak ważna jest otoczka wokół brandu. Są przykładami jak budować narrację marki i jak dzięki niej przyciągać młodych klientów" ${ }^{12}$. Receptą na sukces marki w skutecznym dotarciu do pokolenia Y jest także „przeprogramowanie” oferty tradycyjnej na cyfrową. Dzieje się tak dlatego, że relacje z marką opierają się często na kontaktach za pomocą mediów społecznościowych (Facebook) a także na recenzjach, które można znaleźć w Internecie.

\section{Edukacja medialna „millenialsów” i ich następców. Pytania i wnioski do dalszych badań}

W tym miejscu docieramy do problemu dotyczącego szeroko rozumianej edukacji medialnej. Spotykamy się z nim już wcześniej, bo na etapie definiowania jej roli w procesie kształcenia poszczególnych grup wiekowych. Dzieje się tak w momencie, gdy chcemy zestawić ze sobą możliwości, jakie daje nam media literacy ${ }^{13}$ z faktycznym zainteresowaniem danym medium (w tym wypadku telewizją), wśród przedstawicieli grupy docelowej. Piotr Drzewiecki, medioznawca i wieloletni propagator edukacji medialnej, we

\footnotetext{
${ }^{12}$ Tamże.

${ }^{13}$ „Media literacy możemy określić jako zdolność do kompetentnej komunikacji we wszystkich formach przekazu, drukowanych i elektronicznych, przejawiającą się w świadomym korzystaniu, rozumieniu, analizie i krytycznej ocenie przekazów słownych, wizualnych i dźwiękowych”. P. Drzewiecki $M E D I A$ AKTYWNI. Dlaczego i jak uczyć edukacji medialnej?, Otwock-Warszawa 2010, s. 13.
} 
wstępie do podręcznika „MEDIA AKTYWNI. Dlaczego i jak uczyć edukacji medialnej?”14 stwierdza: „Podstawą edukacji medialnej jest mądre planowanie wolnego czasu, by media nie zawłaszczyły go w całości" ${ }^{15}$. Obserwując postępowanie, nawyki i upodobania przedstawicieli pokolenia Y, można jednak zadać pytanie, czy w wypadku tej grupy należy obawiać się o zawłaszczenie czasu przez media? A jeśli tak, to przez jakie media?

Z pewnością ze względu na szybko zmieniającą się rzeczywistość, zwłaszcza w obszarze współczesnych mediów, na powyższe pytania nie ma łatwych odpowiedzi. Częściowo zdaje się to potwierdzać opublikowany w 2012 roku raport „Cyfrowa przyszłość. Edukacja medialna i informacyjna w Polsce. Raport otwarcia”, który był pierwszą w Polsce próbą kompleksowego opisania stanu wiedzy o kompetencjach medialnych Polaków oraz wizjach rozwoju tych kompetencji. W raporcie znajdziemy opis najważniejszych zagrożeń, wyzwań i obszarów działań związanych z edukacją medialną i informacyjną w Polsce. Autorzy piszą o „(...) konieczności przygotowania i wdrożenia całościowego i komplementarnego programu edukacji medialnej i informacyjnej w naszym kraju" ${ }^{\prime 16}$. Jednak, z drugiej strony, są świadomi problemów, związanych zwłaszcza z bardzo szybką dezaktualizacją opracowanych materiałów. We wstępie do raportu Jarosław Lipszyc stwierdza: „Świat komunikacji zapośredniczonej przez media zmienia się w tempie uniemożliwiającym zbudowanie w sferze edukacji medialnej kompletnego zasobu dydaktycznego - nasze potrzeby informacyjne zmieniają się tak szybko, że jakikolwiek sztywny i zamknięty system po prostu nie będzie w stanie odpowiednio szybko na te zmiany reagować. Zmienia się również nasz stan wiedzy na temat kompetencji medialnych polskich obywateli. W miarę, jak „badawcze białe plamy” będą wypełniane treścią, niezbędne będzie wprowadzanie do naszych planów zmian i korekt" ${ }^{\prime 1}$.

W 2017 roku magazyn „Press” przeprowadził badanie pod nazwą „Kto nas zastąpi?" " wyższych w całym kraju, dedykowaną ankietę wypełniło 191 studentów. Wśród wyników, które wydają się być interesujące w dalszych rozważaniach na temat roli edukacji medialnej w kontekście zmian zachodzących w upodobaniach pokolenia Y, na szczególną uwagę zasługują te dane, które traktują o aktualnych trendach w korzystaniu z mediów. Wśród ankietowanych studentów:

- 46 proc. nie ogląda telewizji

- 33,8 proc. nie czyta prasy

\footnotetext{
${ }^{14}$ Podręcznik przygotowano w ramach projektu badań statutowych „Metody aktywizujące w edukacji medialnej”, realizowanego w 2009 r., na Uniwersytecie Kardynała Stefana Wyszyńskiego w Warszawie.

${ }^{15}$ Tamże, s. 7.

${ }^{16}$ Raport: Cyfrowa przyszłość. Edukacja medialna i informacyjna w Polsce, data publ. 08.03.2012, http://nck.pl/badania/318622-raport-cyfrowa-przyszlosc-edukacja-medialna-i-informacyjna-w-polsce/ (dostęp: 04.09.2017).

${ }^{17}$ J. Lipszyc, Cyfrowa przyszłość. Edukacja medialna i informacyjna w Polsce, Warszawa 2012, s. 6.

${ }^{18}$ Raport „Press”: czego oczekują studenci dziennikarstwa, data publ. 05.07.2017, http://www.press.pl/tresc/49112,raport-_press__-czego-oczekuja-studenci-dziennikarstwa (dostęp: 07.09.2017).
} 


\section{OBLICZA MEDIÓW I KOMUNIKACJI}

- 15,1 proc. nie słucha radia

- 100 proc. korzysta z internetu

Przykłady z zajęć dydaktycznych, podane na początku niniejszego artykułu, wskazują na dość duży dystans do tradycyjnie pojmowanej telewizji wśród obecnych studentów. Jak zatem „edukować medialnie” osoby, które, przynajmniej według obserwacji, są danym medium zainteresowane w niewielkim stopniu? Piotr Drzewiecki uważa że: „Edukacja medialna jest nie tyle wiedzą o mediach, co sztuką mądrego korzystania z mediów, traktowania ich jako pomocy służących do poznawania prawdy o świecie"19. O ile w przypadku dzieci czy osób starszych istnieje realna potrzeba, ale także szansa, na wdrożenie programów, które przyniosą efekty w postaci pomocy odnalezienia się w świecie mediów, o tyle dzisiejsi „millenialsi”, to już nie tylko osoby dojrzałe, ale przede wszystkim wzrastające w otoczeniu mediów, zwłaszcza mediów społecznościowych, które są ich „naturalnym środowiskiem”. Może w takim wypadku powinniśmy z edukacji medialnej wyłączyć tę grupę? A może zmodyfikować wcześniejszy program nauczania i wykreślić z niego te media, którymi dana grupa nie jest zainteresowana? Tylko czy w takim wypadku w dalszym ciągu możemy posługiwać się terminem „edukacja medialna"?

\section{Prezentacja narzędzia badawczego}

Pragnąc znaleźć odpowiedzi na powyższe, ale również wiele innych pytań, które nasuwały się podczas analizowania zagadnienia, zespół badawczy stworzony na UKSW w Warszawie nawiązał współpracę z Laboratorium Badań Medioznawczych Uniwersytetu Warszawskiego, gdzie powstał projekt badania pod nazwą „Telewizja tradycyjna, on-line i społecznościowa jako narzędzie edukowania pokolenia Y”.Podczas opracowania ramowej konceptualizacji badania wyłoniono następujące cele poznawcze, które zakładały:

- zbadanie sposobów konsumowania telewizji przez przedstawicieli pokolenia Y,

- wyjaśnienie czynników wpływających na sposób konsumowania telewizji przez pokolenie Y,

- wskazanie audycji telewizyjnych (gatunki i nazwy własne) preferowanych przez przedstawicieli pokolenia $Y$,

- wskazanie, jakiego typu treści poszukują przedstawiciele pokolenia Y w poszczególnych gatunkach telewizyjnych,

- ustalenie, skąd pokolenie Y czerpie wiedzę na temat audycji telewizyjnych - ich tematyki, godzin i dni emisji.

Wiedzę na temat przedstawionego problemu badawczego miały dać odpowiedzi na postawione pytania badawcze:

${ }^{19}$ P. Drzewiecki, MEDIA AKTYWNI. Dlaczego i jak uczyć edukacji medialnej?, Otwock-Warszawa 2010, s. 6. 
- czy, a jeśli tak, to jak i w jakim stopniu przedstawiciele pokolenie Y konsumują telewizję tradycyjną?

- jakie czynniki wpływają na wzrost lub zmniejszenie zainteresowania pokolenia Y telewizją tradycyjną (linearną) oraz nielinearną?

- czy i jeżeli tak, to jakie nawyki/zwyczaje konsumowania różnych gatunków telewizyjnych można zaobserwować wśród przedstawicieli pokolenia Y?

Wnioskując z obserwacji, rozmów i ćwiczeń, przeprowadzonych w trakcie zajęć dydaktycznych, postawiono siedem hipotez, których potwierdzenie lub zaprzeczenia oczekiwano w wyniku projektowanej ankiety.

Hipotezy:

1. Gatunek audycji telewizyjnych emitowanych w tradycyjnej telewizji wpływa na poziom oglądalności wśród osób należących do pokolenia Y.

2. Pokolenie Y chętniej korzysta z telewizji nielinearnej niż tradycyjnej.

3. Pokolenie Y nie poszukuje w telewizji tradycyjnej audycji edukacyjnych.

4. Zainteresowanie pokolenia Y jest skoncentrowane na konkretnych audycjach telewizyjnych.

5. Osoby z pokolenia Y w telewizji tradycyjnej częściej oglądają audycje o charakterze rozrywkowym i sportowym niż informacyjnym.

6. Telewizja VOD oraz materiały o charakterze self-publishing wpływają na zmniejszenie zainteresowania pokolenia Y tradycyjną telewizją.

7. Internet jest źródłem wiedzy na temat audycji telewizji tradycyjnej dla osób należących do pokolenia Y.

Celem projektu badawczego było określenie sposobów konsumowania telewizji przez przedstawicieli tzw. pokolenia $\mathrm{Y}$ - w tym przypadku studentów studiów dziennikarskich. Założeniem było uzyskanie odpowiedzi na pytania dotyczące czynników wpływających na sposób konsumowania telewizji przez przedstawicieli pokolenia Y oraz poznanie programów, które preferują ${ }^{20}$.

Badanie obejmowało studentów kierunku dziennikarstwo: pierwszego roku studiów licencjackich oraz pierwszego roku studiów magisterskich na Uniwersytecie Kardynała Stefana Wyszyńskiego oraz Uniwersytecie Warszawskim. W celu zapewnienia jak najwyższej frekwencji podczas badania, przeprowadzono je podczas zajęć obowiązkowych. Łącznie kwestionariusz skutecznie i kompletnie wypełniły 363 osoby $^{21}$. Pomiar został przeprowadzony w okresie 22 maja - 1 czerwca 2017 r.

W badaniu posłużono się metodą ankiety CAWI (Computer Assisted Web Interviews) realizowaną w modelu audytoryjnym. Przedstawiciele zespołu badawczego stawili się w salach wykładowych na początku zajęć, informowali krótko o charakterze ba-

\footnotetext{
${ }^{20}$ Na podstawie materiałów Laboratorium Badań Medioznawczych Uniwersytetu Warszawskiego

${ }^{21}$ Odpowiednio: Uniwersytet Warszawski - 228 osób, Uniwersytet Kardynała Stefana Wyszyńskiego - 135 osób.
} 


\section{OBLICZA MEDIÓW I KOMUNIKACJI}

dania, następnie podawali adres strony internetowej, na której znajdował się kwestionariusz. Respondenci wypełniali ankietę za pomocą urządzeń elektronicznych z dostępem do internetu (znaczna większość - na własnych smartfonach, laptopach, tabletach lub w kilku przypadkach - na komputerach stacjonarnych dostępnych w salach zajęciowych).

Kwestionariusz badawczy został wypracowany w toku spotkań i konsultacji zespołu prowadzącego projekt ze strony Uniwersytetu Kardynała Stefana Wyszyńskiego z zespołem wspierającym z Laboratorium Badań Medioznawczych Uniwersytetu Warszawskiego. Po analizie celów projektu badawczego, charakterystyki respondentów, ograniczeń czasowych i możliwości technologicznych oprogramowania wspierającego zbieranie danych wypracowano kwestionariusz, obejmujący 26 pytań (zamkniętych i otwartych, jedno-i wielokrotnego wyboru). Pytania dotyczyły kolejno:

- korzystania z poszczególnych typów telewizji (tradycyjnej, internetowej, VOD) i preferencji w tym zakresie,

- częstotliwości korzystania z poszczególnych typów telewizji,

- oglądanych stacji telewizyjnych,

- celów i motywacji w konsumowaniu poszczególnych rodzajów treści,

- oglądanych audycji telewizyjnych i motywacji, jakie temu przyświecają,

- źródła wiedzy o poszczególnych audycjach telewizyjnych,

- preferencji w wyborze określonego typu telewizji w poszukiwaniu określonego rodzaju treści,

- „typowego” tygodnia telewizyjnego, uwzględniającego wskazanie zazwyczaj oglądanych audycji i stacji w przedziałach godzinowych poszczególnych dni.

Pytania merytoryczne zostały uzupełnione pytaniami metryczkowymi (wiek, płeć, macierzysta uczelnia, rok studiów, kierunek studiów, ukończony kierunek studiów pierwszego stopnia).

\section{Zakończenie}

Wyniki badania poddawane są obecnie analizie, w efekcie której spodziewane jest uzyskanie odpowiedzi na postawione pytania badawcze. Interesujące powinno być także potwierdzenie lub zaprzeczenie przedstawionych hipotez, jak również określenie, czy jakieś pytania należałoby pogłębić lub z których zrezygnować.

Ponadto, wyniki badania mogą posłużyć jako punkt wyjścia do kolejnych badań medioznawczych. W fazie koncepcyjnej jest przygotowanie badań jakościowych (wywiady grupowe). Następnym polem eksploracji mogłoby być porównanie wyników otrzymanych w badaniu studentów dziennikarstwa (obszar nauk społecznych) ze studentami innych kierunków z obszaru nauk ścisłych, technicznych czy przyrodniczych. Projektowane działania dają nadzieję na pogłębienie wiedzy o potrzebach, motywacji, oczekiwa- 
niach i nawykach „millenialsów” wobec różnych typów programów telewizyjnych i różnych sposobów ich emitowania.

\section{BIBLIOGRAFIA}

Drzewiecki P., MEDIA AKTYWNI. Dlaczego i jak uczyć edukacji medialnej?, Otwock - Warszawa 2010.

Drzewiecki P., Edukacja medialna a nauczanie religii w szkole, Warszawa 2013. Jarosz M., Drzewiecki P., Płatek P. (red.), Sport w mediach, Warszawa 2013. Leoński W., Work - Life Balance jako praktyka koncepcji społecznej odpowiedzialności biznesu, http://apcz.umk.pl/czasopisma/index.php/AUNC_ZARZ/article/viewFile/AUNC_ZARZ.2015.010/7152, publ. 23.07.2015.

Lipszyc J., Cyfrowa przyszłość. Edukacja medialna i informacyjna w Polsce, Warszawa 2012.

Radzięta S., Czego spodziewać się po pokoleniu Y?, Rynekpracy.pl https://rynekpracy.pl/artykul.php/typ.1/kategoria_glowna.324/wpis.826, publ. 22.09.2014.

Raport: Cyfrowa przyszłość. Edukacja medialna i informacyjna w Polsce, Narodowe Centrum Kultury http://nck.pl/badania/318622-raport-cyfrowa-przyszlosc-edukacja-medialna-i-informacyjna-w-polsce/, publ. 08.03.2012.

Raport „Press”: czego oczekują studenci dziennikarstwa, Press http://www.press.pl/tresc/49112,raport-_press__-czego-oczekuja-studenci-dziennikarstwa publ. 05.07.2017.

Stańczak K., Jak sprzedawać tym, którzy nie mają potrzeby posiadania?, Forbes https://www.forbes.pl/opinie/millenialsi-pokolenie-y/lfbx6sg, publ. 18.07.2016.

Edukacja medialna, http://edukacja-medialna.wyklady.org.

\section{OAUTORZE:}

mgr Tomasz Knecht - asystent w Instytucie Edukacji Medialnej i Dziennikarstwa, Wydział Teologiczny UKSWw Warszawie, KONTAKT: t.knecht@uksw.edu.pl

Absolwent Wydziału Dziennikarstwa i Nauk Politycznych UW i studium Warsaw Journalism Center. Doktorant na Wydziale Nauk Historycznych i Społecznych UKSW. Wieloletni pracownik $w$ działach marketingu mediów i wydawnictw, m.in. G+J Polska (National Geographic), Murator (Super Express), Bauer (Motor), PPWK SA. Pola zainteresowań badawczych: marketing medialny, promocja, zachowania konsumenckie, komunikacja marketingowa, marketing polityczny. 


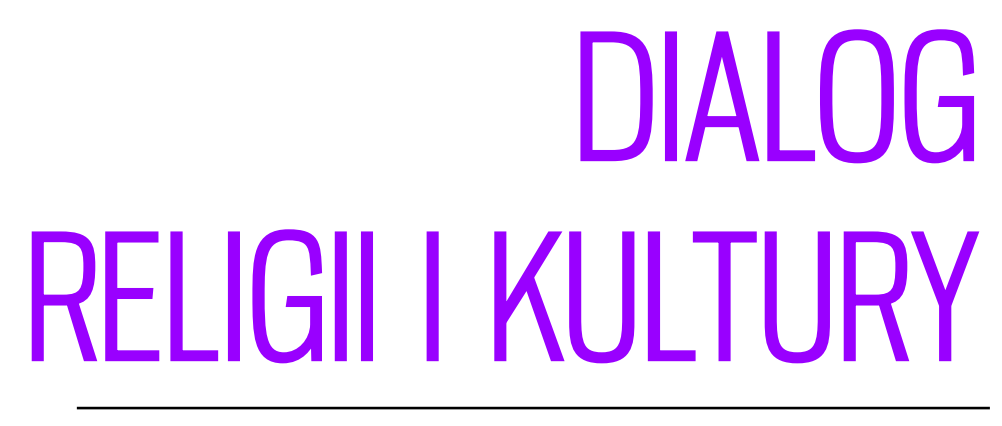


KuLTura - MeDia- TeoLogia

ISSN 2081-8971

$2017 \mathrm{nr} 30$, s. 162-173.

\title{
Powstanie Warszawskie
}

\section{oczami Sióstr Zmartwychwstanek - obrona „Twierdzy Zmartwychwstanek”}

\author{
The Warsaw Uprising eyed by Sister of Resurrection \\ - defence of the "Sisters of the Resurrection Fortress"
}

\begin{abstract}
STRESZCZENIE:
POWSTANIE WARSZAWSKIE JEST JEDNYM Z NAJBARDZIEJ DRAMATYCZNYCH WYDARZEŃ W HISTORII POLSKI. ZRYW ZBROJNY PRZECIWKO NIEMIECKIEMU OKUPANTOWI ZAKOŃCZYŁ SIĘ KLĘSKĄ. ODWAGA I MĘSTWO POLAKÓW, ZARÓWNO ŻOŁNIERZY, JAK I LUDNOŚCI CYWILNEJ, DO DZIŚ BUDZI PODZIW I ZDUMIENIE. WŚRÓD BOHATERÓW

TYCH TRAGICZNYCH DNI NIE ZABRAKŁO SIÓSTR ZAKONNYCH. SZCZEGÓLNE MIEJSCE NA KARTACH HISTORII POWSTAŃCZEJ WARSZAWY ZAJMUJĄ SIOSTRY ZMARTWYCHWSTANKI. ODDAJĄC SWÓJ DOM ZAKONNY NA SZPITAL POWSTAŃCZY NIE PRZYPUSZCZAEY NAWET, ŻE

NIEBAWEM STANIE SIĘ ON NIEUGIĘTYM PUNKTEM OBRONY MIASTA: „REDUTĄ ŻOLIBORZA”, „TwIERDZĄ

ZMARTWYCHWSTANEK”. ARTYKUŁ PRZEDSTAWIA RELACJE SIÓSTR Z OGARNIĘTEJ WALKĄ DZIELNICY

WARSZAWY, NA PODSTAWIE KTÓRYCH MOŻNA ODTWORZYĆ DRAMATYCZNĄ HISTORIĘ ŻOLIBORSKIEGO KLASZTORU, JAK I ZYSKAĆ WGLĄD W POSTAWE SIÓSTR W OBLICZU ZAGŁADY.
\end{abstract}

\section{SŁOWA KLUCZOWE:}

Powstanie WarsZaWsKIE, 1944 R., REdUTA Żoliborza, TwierdZa ZMARTWYCHWSTANEK, ZGromadZenie Sióstr ZMartwychwstania PAŃSKIEgo, ZMARTWYCHWSTANKI

\section{ABSTRACT:}

THE WARSAW UpRISING IS ONE OF THE MOST DRAMATIC EVENTS IN Polish history. AN ACT OF OPPOSITION TO THE GERMAN OCCUPATION RESULTED IN A GREAT DISASTER. VALOUR AND COURAGE OF MANY POLES, BOTH SOLDIERS AND CIVILIANS, STILL AWAKEN AN ADMIRATION AND AMAZEMENT FOR THEM. INDEED, AMONG THE HEROES OF THOSE TRAGIC DAYS THERE WERE ALSO CATHOLIC NUNS. SiSTERS OF THE RESURRECTION HAVE A SPECIAL PLACE IN THE HISTORY OF INSURGENT WARSAW. GIVING THEIR CONVENT FOR INSURGENT HOSPITAL THEY DID NOT SUPPOSE THAT SOON IT WILL BECOME A RELENTLESS POINT OF THE CITY DEFENCE: "STRONGHOLD OF ZOLIBORZ", “the Sisters of the Resurrection Fortress”. The ARTICLE PRESENTS A HISTORY OF THE MENTIONED EARLIER MONASTERY, THE SISTER'S MEMORIES OF CITY DISTRICT DURING THE BATTLE, BASED ON WHICH, WE CAN RECONSTRUCT DRAMATIC STORY OF THEIR NUNNERY AS WELL TO GAIN AN INSIGHT INTO THE NUN'S ATTITUDE IN THE FACE OF HOLOCAUST.

\section{KEYWORDS:}

WARSAW UpRISING, 1944, Fortress Sisters OF THE RESURReCtion, The CONGREgation OF the Sisters of THE RESURRECTION 
rzy ulicy Krasińskiego 31 na warszawskim Żoliborzu znajdują się klasztor Sióstr
Zmartwychwstanek ${ }^{1}$ oraz prowadzona przez Zgromadzenie placówka edukacyj-
na, w skład której wchodzą obecnie szkoła podstawowa, gimnazjum (wygaszane) oraz liceum ogólnokształcące. Choć z zewnątrz nic na to nie wskazuje, jest to miejsce niezwykłe i mogące poszczycić się bardzo bogatą historią, sięgającą początków XX wieku.

$\mathrm{W}$ artykule zostanie przedstawiony jeden z bardziej dramatycznych okresów w dziejach tego miejsca. Będzie nim czas Powstania Warszawskiego, który w klasztorze Sióstr Zmartwychwstanek zapisał się w sposób szczególny. Powrót do tych z trudem dających się opisać momentów, jest możliwy dzięki trzem lekturom, które stanowią najważniejsze pozycje w bibliografii niniejszego artykułu. Są nimi: Dziennik pielęgniarki z Powstania Warszawskiego autorstwa s. Emilii Radziszewskiej ${ }^{2}$, książka Widziane ze schronu napisana przez s. Melanię Palm ${ }^{3}$ oraz opracowanie s. Marii Lucyny Misteckiej ${ }^{4}$

\footnotetext{
${ }^{1}$ Zgromadzenie Sióstr Zmartwychwstania Pana Naszego Jezusa Chrystusa, zwane też Zgromadzeniem Sióstr Zmartwychwstania Pańskiego (zmartwychwstanki), powstało w Rzymie w dniu 6 stycznia 1891 r. Zostało założone przez dwie Polki, Celinę Borzęcką i jej córkę Jadwigę. Powołaniem Zgromadzenia jest wielbienie Boga i głoszenie światu prawdy o Jego miłości przez uczestnictwo w Paschalnym Misterium Zbawienia. Siostry odwzajemniają tę miłość, idąc za Chrystusem, zgodnie z hasłem Zgromadzenia „przez krzyż i śmierć do zmartwychwstania i chwały”, a także dzieląc się dobrem wynikającym z otrzymanego charyzmatu. Łącząc życie kontemplacyjne z działalnością apostolską, starają się o religijne i moralne odrodzenie świata w duchu ewangelicznych błogosławieństw. Otwierają się na potrzeby bliźnich, posługując jako nauczycielki, wykładowczynie, wychowawczynie, przewodniczki duchowe, misjonarki, animatorki, rekolekcjonistki, katechetki, pielęgniarki, opiekunki dzieci, chorych, starszych i potrzebujących. Aktualnie siostry pełnią swoją misję w Polsce, we Włoszech, w Stanach Zjednoczonych, Kanadzie, Wielkiej Brytanii, Australii, Argentynie, na Białorusi, a także w Tanzanii. Całym swoim życiem - słowem, modlitwą i pracą apostolską - głoszą Dobrą Nowinę o Zmartwychwstaniu Chrystusa, realizując w ten sposób paschalny charyzmat Zgromadzenia. Por. M. L. Mistecka, Zmartwychwstanki charyzmat i dzieje 1891-1991, Lublin 2000, t. II, s. 313-530.

${ }^{2}$ S. Emilia - Maria Radziszewska, ur. 1 listopada 1908 r. w Łojewie. W szpitalu powstańczym pełniła funkcję pielęgniarki. Zmarła w Częstochowie dnia 23 września 2003 r. w wieku 95 lat (w Zgromadzeniu: 70 lat). Zob. M. L. Mistecka, Zgromadzenie Sióstr Zmartwychwstania Pańskiego w czasie Powstania Warszawskiego, Lublin 1980, s. 137.

${ }^{3}$ S. Melania - Melania Palm, ur. 29 kwietnia 1909 r. w Warszawie. W trakcie Powstania przebywała w żoliborskim klasztorze i opiekowała się dziewczętami, które pozostały na czas wakacji w szkolnym internacie. Zmarła w Mocarzewie dnia 6 lutego 2001 r. w wieku 91 lat (w Zgromadzeniu: 73 lata). Zob. M. L. Mistecka, Zgromadzenie Sióstr..., dz. cyt., s. 138.

${ }^{4}$ S. Maria Lucyna - Lucyna Mistecka, ur. 28 października 1930 r. w Natalinie na Wileńszczyźnie. W 1955 r. wstąpiła do Zgromadzenia Zmartwychwstanek. W 1957 r. złożyła pierwsze śluby. Ukończyła studia magisterskie i doktoranckie na Katolickim Uniwersytecie Lubelskim. W 1980 r. została wybrana radną generalną. W 2002 r. powróciła do prowincji macierzystej. Jest autorką wielu ważnych publikacji dotyczących historii Zgromadzenia: m.in. trzech tomów pt. Zmartwychwstanki charyzmat i dzieje 18911991, Zmartwychwstanki w okupowanej Polsce oraz Zmartwychwstanki w czasie Powstania Warszawskiego. Przygotowywała ponadto trzy tomy listów Matki Celiny do córki Jadwigi z lat 1893-1894. Zmarła w Częstochowie dnia 10 lutego 2005 r. w wieku 74 lat (w Zgromadzeniu: 50 lat). Zob. Nekrolog s. M. Lucyny Misteckiej autorstwa s. Teofili Matusiak, mps.
} 
pt. Zgromadzenie Sióstr Zmartwychwstania Pańskiego w czasie Powstania Warszawskiego, będące pierwszą próbą całościowego ukazania życia i posługi sióstr zmartwychwstanek w 1944 roku. Wymienione publikacje nie są dostępne dla szerszego grona odbiorców, co tym bardziej skłania do przywołania ich przesłania i treści.

Wobec podjętego zagadnienia pojawiają się pytania, jak warunki powstańcze wpłynęły na życie i posługę sióstr. Czy były one w stanie zachować styl życia właściwy osobom zakonnym? Czy w tak trudnych chwilach potrafiły nieść innym pomoc i dodawać otuchy potrzebującym pocieszenia? Jaki przykład dawały bliźnim? Czy bliska relacja z Bogiem i modlitwa pomogły im przeżyć tragiczne chwile? Na te i podobne pytania postaram się odpowiedzieć przywołując wspomnienia sióstr zawarte w wyszczególnionych powyżej lekturach. Temat ten zostanie przedstawiony na płaszczyźnie historycznej, ukazując funkcjonowanie zakonu jako szpitala powstańczego do momentu ewakuacji, jak i problemowej, ilustrując dezorganizację codziennego życia sióstr w obliczu Zagłady i ich heroiczne wysiłki podjęte celem sprawowania typowej posługi.

Przed przystąpieniem do analizy wybranego tematu warto napisać kilka słów o historii klasztoru Sióstr Zmartwychwstanek na warszawskim Żoliborzu. W 1928 r. Zgromadzenie rozpoczęło budowę olbrzymiego kompleksu zwanego „Zakładami Naukowo-Wychowawczymi Sióstr Zmartwychwstanek”, w którym mieściły się seminarium nauczycielskie, przedszkole, szkoła powszechna, gimnazjum oraz liceum ogólnokształcące. Na ich czele stanęła wówczas s. Amata Kossowska ${ }^{5}$. Pomimo trudnych wojennych warunków, do momentu wybuchu Powstania, każdego roku w czasie wojny w liceum na Żoliborzu odbywał się egzamin maturalny. Ponadto, regularnie organizowano akademie patriotyczne i religijne, rekolekcje i dni skupienia, warsztaty oraz spotkania absolwentek. Podczas okupacji tajnym nauczaniem zostało objętych ok. 1000 dzieci i młodzieży, a w bardzo dobrze wyposażonym internacie mieszkało ok. 100 dziewcząt. W klasztorze żyło zaś ponad 90 sióstr zmartwychwstanek. Posługa sióstr nie ograniczała się jednak tylko do działalności oświatowej, ale obejmowała również pracę charytatywną na rzecz najbardziej ubogich i potrzebujących. Jak pokazują powyższe dane, szczytowym momentem rozwoju żoliborskiej placówki był właśnie czas okupacji ${ }^{6}$.

\section{Klasztor jako szpital i twierdza powstańcza}

Po wybuchu Powstania Warszawskiego (1 sierpnia 1944 r.) szkoła i klasztor zamieniły się na szpital powstańczy, będący największym punktem sanitarnym na terenie XXII obwodu Armii Krajowej na Żoliborzu. Komendantem tego rejonu został ppłk Mieczysław Niedzielski, pseudonim „Żywiciel”. Miejsce to zostało objęte planem przygotowań do Powstania już

\footnotetext{
${ }^{5}$ S. Amata - Marta Kossowska, ur. 19 lipca 179 r. w Warszawie. W 1919 r. wstąpiła do Zgromadzenia Sióstr Zmartwychwstanek. Dwa lata później złożyła pierwsze śluby zakonne i rozpoczęła pracę nauczycielską. W 1930 r. stanęła na czele klasztoru i szkół żoliborskich. Zmarła w Warszawie w dnia 22 marca 1934 r. Zob. M. L. Mistecka, Zgromadzenie Sióstr..., dz. cyt., s. 20.

${ }^{6}$ Zob. M. L. Mistecka, Zgromadzenie Sióstr..., dz. cyt., s.20-22.
} 
w połowie 1942 r. Swoją gotowość wyraziły wtedy Matka Małgorzata Dąbrowska ${ }^{7}$, ówczesna przełożona prowincjalna, i s. Beata Przybyłowicz ${ }^{8}$, przełożona domu żoliborskiego.

W 1944 r. została zaprzysiężona lekarka - s. Amata Pruszko ${ }^{9}$. Od dnia 26 lipca do klasztoru przetransportowano kilka ton żywności dla potrzeb organizowanego szpitala (m.in. mąki, kaszy, grochu, suszonych ziemniaków, soli, cukru i konserw mięsnych). Dodatkowo, klasztor zaopatrzono w niezbędne wyposażenie lecznicze. Jak wyjaśnia s. M. L. Mistecka, działania te były bardzo niebezpieczne, ponieważ w przypadku rewizji posiadanie tak znacznych zapasów pożywienia, materiałów opatrunkowych, leków i narzędzi chirurgicznych trudno byłoby usprawiedliwić, nawet powołując się na istnienie schronu przeciwlotniczego w suterenach budynku ${ }^{10}$. Należy podkreślić, że pomimo tak szeroko zakrojonych przygotowań usytuowanie szpitala powstańczego nr 100 było do końca utrzymywane w tajemnicy do tego stopnia, że nawet siostry (z wyjątkiem kilku wtajemniczonych w to przedsięwzięcie) zostały poinformowane przez przełożoną o fakcie ulokowania szpitala w budynku zakonnym dopiero w dniu wybuchu Powstania.

Można zapytać, co zadecydowało o wyborze klasztoru na miejsce szpitala powstańczego. Przede wszystkim było to jego położenie w pobliżu centrum dzielnicy oraz latwość ukrycia przygotowań do wybuchu Powstania pod pozorem prowadzonego przez siostry internatu. Ponadto, znaczenie miała spora liczba zakonnic, które można było zaangażować do pracy w charakterze personelu szpitala, oraz uczennic, które służyły w Powstaniu jako łączniczki i sanitariuszki.

\footnotetext{
${ }^{7}$ S. Małgorzata - Maria Izabela Dąbrowska, ur. 12 września 1880 r. w Michałowicach k. Krakowa. Do Zgromadzenia wstąpiła 28 września 1901 r. Pierwsze śluby złożyła 12 czerwca 1903 r. Podczas III Kapituły Generalnej została wybrana na urząd przełożonej generalnej. Posługę tę pełniła przez 12 lat w okresie od 1926-1938 roku. Następnie została przełożoną Prowincji Warszawskiej - jej urzędowanie przypadło na czas wybuchu Powstania Warszawskiego. Zmarła 10 października 1948 r. w Kętach w wieku 68 lat (w Zgromadzeniu: 47 lat). Zob. M. L. Mistecka, Zgromadzenie Sióstr..., dz. cyt., s. 23.

${ }^{8}$ S. Beata - Maria Przybyłowicz, ur. 28 stycznia 1899 r. w Płocku. W marcu 1920 r. przybyła do Kęt i tam rozpoczęła postulat. Dnia 2 lutego 1921 r. odbyły się obłóczyny. Rok później s. Beata złożyła pierwsze śluby i wyjechała do Domu Alumnatu w Warszawie. W Stolicy kontynuowała studia uniwersyteckie oraz rozpoczęła pracę w Seminarium Nauczycielskim jako nauczycielka polonistyki. Profesję wieczystą złożyła w Kętach 2 lutego 1927 r. Od lipca 1927 r. została mianowana przez matkę generalną przełożoną domu zakonnego na Sewerynowie w Warszawie oraz objęła urząd Mistrzyni Alumnatu. Od roku 1930 pracowała w klasztorze na Żoliborzu jako nauczycielka języka polskiego. W 1938 r., po Kapitule Generalnej, została mianowana przełożoną Domu Żoliborskiego i piastowała ten urząd także w trakcie Powstania Warszawskiego. W styczniu 1946 r. została mianowana Przełożoną Prowincji Poznańskiej. Zmarła po ciężkiej chorobie 3 listopada 1950 r. w Poznaniu w wieku 51 lat (w Zgromadzeniu: 30). Zob. Nekrologi Zmarłych Sióstr Zmartwychwstania Pana Naszego Jezusa Chrystusa od lipca do grudnia 1981-1956, t. II, mps.

${ }^{9}$ S. Amata - Wanda Pruszko, ur. 12 czerwca 1912 r. w Warszawie. Ukończyła Wydział Lekarski Uniwersytetu Warszawskiego. Do Zgromadzenia Sióstr Zmartwychwstanek wstąpiła w 1941 r. Organizowała szpital powstańczy i posługiwała w nim jako lekarka. Za te zasługi Dowództwo Armii Krajowej odznaczyło ją Krzyżem Powstania Warszawskiego i Armii Krajowej. Zmarła w Warszawie dnia 2 marca 1985 r. w wieku 72 lat (w Zgromadzeniu: 44 lata). Zob. M. L. Mistecka, Zmartwychwstanki charyzmat i dzieje..., t. II, dz. cyt., s. 101.

${ }^{10}$ Zob. M. L. Mistecka, Zgromadzenie Sióstr..., dz. cyt., s. 49.
} 
Jak rozpoczęło się Powstanie na Żoliborzu? Dnia 1 sierpnia około godziny 14.00, czyli wcześniej, niż oficjalnie zaplanowano, w pobliżu klasztoru rozległa się pierwsza strzelanina. Godzinę później do klasztoru przybył niemiecki patrol i zażądał rewizji budynku, podejrzewając, że to właśnie stamtąd padły strzały. S. Rafaela Gdaniec ${ }^{11}$ dyżurująca w tym czasie na furcie, wspaniale władająca językiem niemieckim, pertraktowała z dowódcą. Polecono wszystkim opuścić gmach. Wtedy Niemcy zagrozili wszystkim obecnym rozstrzelaniem, jeśli na terenie domu zostanie znaleziona broń. Przeszukano pomieszczenia oraz przybyły tego dnia do sióstr konwój z mąką, w którym ukryte było uzbrojenie przeznaczone dla powstańców. Na szczęście podczas rewizji nic nie znaleziono. Co więcej, żołnierz niemiecki przechodząc przez sale z rozstawionymi łóżkami nie domyślił się ich przeznaczenia. Jak opisuje tę scenę s. M. L. Mistecka: „,nie przypuszczał, że rozpoczęło się powstanie, gdyż nie pozostawiłby bez obsady gmachu, którego zdobycie kosztowało później Niemców wiele ofiar w ludziach i wiele materiału artyleryjskiego" ${ }^{2}$. Te chwile ogromnego napięcia s. E. Radziszewska relacjonuje w ten sposób: „Odeszli. A my - odetchnęliśmy głęboko - wracaliśmy z krawędzi śmierci do życia. Wróciłyśmy do opustoszałego chwilowo domu - naszego domu - naszego klasztoru. Nie przypuszczałyśmy, że będziemy w nim przebywały jeszcze zaledwie kilkanaście dni, a potem już nigdy nie zobaczymy go takim, jakim był przez czternaście lat swojego istnienia. Pierwszy akt, a raczej wstęp do rozpoczynającej się »Rapsodii Warszawskiej i Żoliborskiej« w naszym domu został zakończony”"13.

Działalność szpitala, usytuowanego początkowo w części parterowej klasztoru od ulicy Krasińskiego w nieistniejącej już części budynku, rozpoczęła się 1 sierpnia o godzinie 20.00. Tego dnia apostolstwo sióstr przybrało nową formę. Siostry posługiwały powstańcom jako lekarki, pielęgniarki, sanitariuszki, kucharki, a także pracując w pralni, szwalni, zapleczu gospodarczym i czuwając przy furcie. Jeszcze dwa dni wcześniej nikt nie przypuszczał, jakie dramatyczne sceny będą rozgrywać się na terenie klasztoru i jak głęboko wpłyną one na życie każdej siostry. Pod datą 30 lipca s. M. Palm zanotowała: „Była to niedziela. [...] Siostry wychodziły z kaplicy. [...] Nikt nie przypuszczał, że dni tragiczne są tuż za progiem. I nikomu z uczestników niedzielnego nabożeństwa nie przyszło na myśl, że w tej pięknej kaplicy nie zbierzemy się już nigdy więcej, ani następnej, ani żadnej niedzieli, że z niej wkrótce nie zostanie - dosłownie kamień na kamieniu" ${ }^{14}$.

\footnotetext{
${ }^{11}$ S. Rafaela - Joanna Gdaniec, ur. 26 marca 1900 r. w Bydgoszczy. W 1921 r. wstąpiła do Zgromadzenia Sióstr Zmartwychwstanek, a dwa lata później złożyła pierwsze śluby. Ukończyła seminarium nauczycielskie oraz konserwatorium muzyczne. Następnie pracowała jako nauczycielka śpiewu i języka niemieckiego. Ze względu na bardzo dobrą znajomość języka obcego w czasie okupacji była wyznaczona do załatwiania spaw urzędowych. W trakcie Powstania Warszawskiego zajmowała się w administracją szpitala. Po wojnie pełniła obowiązki radnej Prowincji Poznańskiej. Zmarła w Poznaniu 27 stycznia 1979 r. w wieku 79 lat (w Zgromadzeniu: 57 lat). Zob. M. L. Mistecka, Zmartwychwstanki charyzmat i dzieje..., t. II, dz. cyt., s. 288.

${ }^{12}$ M. L. Mistecka, Zgromadzenie Sióstr..., dz. cyt., s. 46.

${ }^{13}$ E. Radziszewska, Dziennik Pielęgniarki z Powstania Warszawskiego, Częstochowa 1996.

${ }^{14}$ M. Palm, Widziane ze schronu, Częstochowa 2001, s. 10.
} 


\section{DIALOG RELIGII I KULTURY}

Pierwsze walki oszczędziły budynek klasztorny, ale szpital znalazł się w bardzo niepewnym położeniu, co uniemożliwiło punktualne stawienie się części obsady lekarskiej. Operacje i zabiegi trwały nieprzerwanie, a liczba rannych (żołnierzy i ludności cywilnej) nieustannie wzrastała. Bezpieczeństwo Zgromadzenia i rannych miała gwarantować Konwencja Genewska, zakładająca neutralność szpitali. Na dachu rozpostarto więc flagi z czerwonym krzyżem i nie wpuszczano nikogo $\mathrm{z}$ bronią. Budynek czasowo pozostał poza linią obrony, co umożliwiło staranną opiekę lekarską i utrzymanie należytej higieny: codzienne obchody lekarskie oraz właściwe przygotowywanie narzędzi chirurgicznych i materiałów opatrunkowych przez ich sterylizację chroniły pacjentów przed śmiertelnymi zakażeniami.

Niestety ten stan rzeczy nie trwał długo - już od 3 sierpnia szpital był systematycznie bombardowany przez samoloty wroga oraz ostrzeliwany przez pociąg pancerny z rejonu Dworca Gdańskiego. Skutkiem tego uszkodzeniu uległa część sali operacyjnej. Przeniesiono ją więc w inne skrzydło budynku, tym razem na parter i do suteren od ulicy Stołecznej. Praca załogi szpitala i sióstr stała się ekstremalnie trudna: 7 sierpnia nie było dostępu do sieci elektrycznej, dlatego operowano przy świetle gromnic i lamp. Pojawił się też problem braku wody. Na szczęście w ciągu kilku dni udało się czasowo przywrócić dostęp do tych niezbędnych mediów ${ }^{15}$.

Trudnym momentem był 10 sierpnia. Tego dnia ostrzeliwanie klasztoru rozpoczęło się już o 5.30 rano. W ciągu godziny na budynek padły 142 pociski, niszcząc część szpitalną. Szpital przeniesiono więc całkowicie do suteren. Warunki stawały się coraz cięższe. W ciągu dwóch tygodni trwania walk wyczerpały się dostarczone zapasy żywności, które na wszelkie sposoby starano się uzupełniać. Ewakuowano pobliskie szpitale i dostarczono siostrom nowych rannych, tak że 17 sierpnia przebywało tam ok. 200 pacjentów $^{16}$. Siostra M. Palm relacjonuje: „Przed Najświętszym Sakramentem siostry leżały po kilka krzyżem, ustawicznie błagając Pana o miłosierdzie. Niezliczoną ilość razy w ciągu dnia schron-kaplica wypełniał się szczelnie. $W$ chwilach bombardowania czułyśmy się tam najbezpieczniejsze. Siostry opiekujące się rannymi zostawały zawsze z nimi. Twierdziły, że wśród pracy zapominały o grozie sytuacji, a ta stawała się coraz wyraźniej sytuacją tonącego z wolna, ale nieuchronnie okrętu. Dom otrzymywał bowiem coraz to nowe uderzenia, które od III piętra do parteru wyrywały zeń ogromne kawały muru. Każde uderzenie pocisku odczuwało się jak bolesne zranienie żywego organizmu. Nie widziałyśmy z zewnątrz naszego klasztoru, ale sądząc po tym, co działo się nad naszymi głowami, wyobrażałyśmy sobie, że ściany jego muszą wyglądać jak sito. Stał jednak, nie walił się, mimo usiłowań Niemców, którzy traktowali go jak twierdzę, przeznaczoną na zrównanie z ziemią. Budowany był chyba na czas... powstania 1944 r. Grube mury solidnej roboty przedłużały teraz życie co najmniej dwustu osobom chroniącym się w suterenach" ${ }^{17}$.

\footnotetext{
${ }^{15}$ Zob. M. L. Mistecka, Zgromadzenie Sióstr..., dz. cyt., s. 52.

${ }^{16}$ Zob. M. Palm, Widziane ze schronu, dz. cyt., s. 53.

${ }^{17}$ Tamże, dz. cyt., s. 36-37.
} 
Należy podkreślić, że wśród pacjentów szpitala byli nie tylko żołnierze, ale także łączniczki, sanitariuszki oraz ludność cywilna. Do szpitala zaczęto przynosić również rannych Niemców, którzy nie zdołali wydostać się z pola walki. Początkowo zachowywali się nieufnie, nie chcieli jeść i pić, spodziewając się otrucia. Jednak obserwując szlachetną postawę personelu szpitala, przełamywali swój upór. Byli zdziwieni, że otrzymują takie same racje żywnościowe jak Polacy, a nawet trudno dostępne papierosy. Jak zauważyła w swojej książce s. M. L Mistecka: „tak byli traktowani jeńcy w Szpitalu Zmartwychwstanek, podczas gdy wróg w tym samym czasie palił żywcem polskich lekarzy, pielęgniarki i nawet chorych w szpitalu na Woli" ${ }^{18}$.

Obok klasztoru nieustannie toczyły się walki, wskutek których w budynek trafiały kolejne kule, tym razem 27 pocisków artyleryjskich. Niemcom udało się również podpalić część budynku, ale pożar szczęśliwie ugaszono z pomocą ofiarnych sąsiadów. Jak zaznacza s. M. L. Mistecka, nie był to jedyny przypadek, w którym okoliczni mieszkańcy przybyli na ratunek. Wspierali oni działalność szpitala od momentu, kiedy tylko dowiedzieli się o jego istnieniu. Ofiarnie dzielili się własnymi dobrami, dostarczając to, czego w danej chwili brakowało. Z narażeniem życia przynosili do klasztoru żywność, pościel, bieliznę, czasem również mięso, wino, słodycze i papierosy, a także kwiaty do ozdobienia kaplicy. Niestety potrzeby szpitala nie mogły być w pełni zaspokajane przez ludność cywilną, której majątek wskutek działań zbrojnych z dnia na dzień ulegał uszczupleniu ${ }^{19}$.

\section{Nowe warunki życia i formy posługi sióstr}

Bez wątpienia dzień 1 sierpnia rozpoczął nowy rozdział życia i posługi żoliborskich zmartwychwstanek. Wszystko zostało podporządkowane rzeczywistości wojennej. Mimo granicznego zmęczenia siostry wstawały codziennie rano na modlitwę, rozmyślanie i Eucharystię. Dzięki zaradności zakrystianki, s. Antonetty Tomaszewicz ${ }^{20}$, która wcześniej zaopatrzyła kaplicę w tysiące komunikantów, codziennie sprawowano msze święte. W klasztorze przebywało w tym czasie trzech księży ${ }^{21}$. Po rozpoczęciu walk nie mogli już wydostać się z oblężonej dzielnicy. Kapłani posługiwali na różne sposoby: sprawowali Najświętszą Ofiarę, spowiadali, ale także opiekowali się rannymi.

Po porannej toalecie, mszy św. i skromnym śniadaniu siostry odchodziły do swoich obowiązków. Najbardziej wymagającymi z nich była praca w kuchni i pralni. Do momentu ewakuacji szpitala posiłki dla chorych były dość dobre, co było możliwe dzięki żywności dostarczonej przed wybuchem powstania, jak również dzięki zapasom będącym własnością Zgromadzenia oraz darom ludzi dobrej woli. Zgodnie z zaleceniem

\footnotetext{
${ }^{18}$ M. L. Mistecka, Zgromadzenie Sióstr..., dz. cyt., s. 56.

${ }^{19}$ Tamże, s. 60-61.

${ }^{20}$ S. Antonetta - Helena Tomaszewicz, ur. 9 sierpnia 1909 r. w Bukatach (woj. wileńskie). W czasie Powstania pełniła obowiązki zakrystianki żoliborskiego klasztoru. Zmarła w Mocarzewie 10 grudnia 1996 r. w wieku 87 lat (w Zgromadzeniu: 67 lat). Zob. M. L. Mistecka, Zgromadzenie Sióstr..., dz. cyt., s. 136.

${ }^{21}$ Kapłanami tymi byli: ks. Eugeniusz Żelazowski, kapelan żoliborskiego klasztoru, spowiednik sióstr ks. J. Cecholm oraz ks. A. Grzymała. Zob. M. L. Mistecka, Zgromadzenie Sióstr..., dz. cyt., s. 46. Nie umiem znaleźć pozostałych imion kapłanów. Musimy zapytać autorkę, albo zrezygnować z imion...
} 


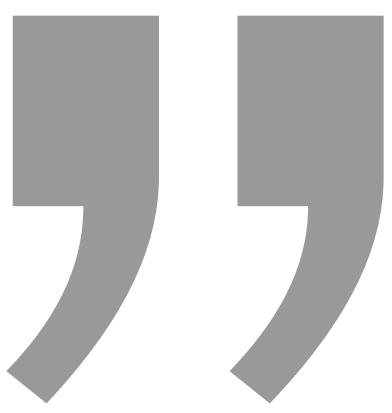

\section{Siostry były zmuszone oswajać się} z coraz bardziej spartańskimi warunkami egzystencji. Po 10 sierpnia musiały przenieść się do suteren, co znacznie zmniejszyło ich przestrzeń życiowa. Nie było mowy o swobodnym poruszaniu się, a zajęcie wygodnej pozycji graniczyło z cudem. Brakowało osobnego miejsca na spoczynek, dlatego siostry spały gdziekolwiek: na podłodze, krzesłach, a nawet klęcznikach znajdujących się w prowizorycznie urządzonej kaplicy.

s. Przełożonej B. Przybyłowicz, posiłki otrzymywali także członkowie rodzin personelu szpitala, pracującego bez wytchnienia dnie i noce. Niestety w miarę upływu czasu wyżywienie wszystkich stawało się niemożliwe ze względu na brak artykułów spożywczych i wyposażenia kuchennego. Coraz trudniej było także utrzymać właściwą higienę. Brak wody i mydła, a później także przestrzeni odpowiedniej na zorganizowanie suszarni uniemożliwiały normalne funkcjonowanie pralni ${ }^{22}$.

Siostry były zmuszone oswajać się z coraz bardziej spartańskimi warunkami egzystencji. Po 10 sierpnia musiały przenieść się do suteren, co znacznie zmniejszyło ich przestrzeń życiową. Nie było mowy o swobodnym poruszaniu się, a zajęcie wygodnej pozycji graniczyło z cudem. Brakowało osobnego miejsca na spoczynek, dlatego siostry spały gdziekolwiek: na podłodze, krzesłach, a nawet klęcznikach znajdujących się w prowizorycznie urządzonej kaplicy. Nad ich głowami przenoszono zwłoki zmarłych i pod osłoną nocy zakopywano je bez trumien w dole od ul. Stołecznej ${ }^{23}$.

Siostra. M. Palm najbardziej dramatycznie wspomina pierwsze dziewięć dni Powstania, kiedy to wszyscy byli zmuszeni oswoić się z niebezpieczną rzeczywistością. Jej wspomnienia dobrze ukazują nie tylko grozę sytuacji, ale przede wszystkim godną podziwu postawę zakonnic, które w tak tragicznych momentach nie tracily wiary, lecz trwały na modlitwie i były gotowe oddać życie za innych. W książce Widziane ze schronu zapisuje: „W tłoku, w mrocznym korytarzu suteren stałyśmy jedna przy drugiej z różańcami w rękach i modliłyśmy się, odczuwając każdym drgnieniem duszy drżenie gmachu od rozrywających się pocisków i bolesny skurcz serca, gdy celnie wymierzony strzał [...] zadawał domowi nową ranę. A przecież to było jeszcze niczym wobec świado-

\footnotetext{
${ }^{22}$ Zob. M. L. Mistecka, Zgromadzenie Sióstr..., dz. cyt., s. 59, 62.

${ }^{23}$ Tamże, dz. cyt., s. 63-64.
} 
mości, że ginie w pobliżu Warszawa [...] a wśród niej siostry na Mokotowskiej, Chłodnej, nasza najdroższa Matka Prowincjalna Małgorzata Dąbrowska. Żadna wieść nie docierała na Żoliborz, który był zupełnie odcięty od miasta, podobny do wysepki otoczonej Niemcami. Tak minęło dziewięć dni. Najdłuższa i najcięższa nowenna cierpienia. Gdyby nie wymowa dat i wtedy, i dziś - trudno byłoby uwierzyć, że to tylko dziewięć dni... Okres ten wydaje się niepomiernie dłuższym, najdłuższym z całego powstania. Może dlatego, że dopiero wdrażałyśmy się do nowych, nad wyraz prymitywnych warunków bytowania, oswajałyśmy się ze wzrastającą grozą sytuacji, traciłyśmy drogi nasz dom, w którym niejedna spędziła znaczną część swojego życia. Bóg odrywał nas od wszystkiego, co doczesne, byłyśmy w pełnym ufności zdaniu się na Jego wolę, przygotowywałyśmy się do ostatniego momentu, do chwili opuszczenia tego srogiego czyśćca i spotkania się z Nim na wieki”"24.

Rzeczywistość wojenna zdezorganizowała życie zakonne we wszystkich jego aspektach. Działania wojenne uniemożliwiły należyte przeprowadzenie uroczystości profesji zakonnej s. M. Pauli Dąbrowskiej ${ }^{25}$. Dnia 11 sierpnia s. Paula złożyła na ręce siostry przełożonej śluby wieczyste, przyspieszone w obawie o życie zakonnic, które ze względu na narastające zagrożenie mogły nie dożyć 15 sierpnia. Wtedy to przypada właściwy dzień składania ślubów w Zgromadzeniu. Relacja s. E. Radziszewskiej dotycząca tego szczególnego momentu jest bardzo lakoniczna: „Zamknięte w naszym domu, jak w skazanym na zagładę okręcie, przeżyłyśmy... uroczystość zakonną... Rankiem, podczas cichej Mszy św. przy akompaniamencie dział nasza Siostra poświęciła się Chrystusowi na zawsze. Jedyna to chyba w dziejach Zgromadzenia profesja zakonna w takich warunkach"26.

\section{Ewakuacja szpitala i zagłada „Iwierdzy Zmartwychwstanek”}

W miarę upływu czasu Klasztor Zmartwychwstanek stał się ostatnim budynkiem zamykającym Niemcom dostęp do Placu Wilsona od strony Cmentarza Powązkowskiego. W ocenie dowództwa nie był już bezpiecznym miejscem dla ludności cywilnej, dlatego siostry oraz wszyscy jego tymczasowi mieszkańcy otrzymali nakaz opuszczenia gmachu. Z uwagi na grożące niebezpieczeństwo, z dnia 18 na 19 sierpnia zarządzono ewakuację szpitala. Ta niezwykle trudna i żmudna akcja trwała dwie noce. Siostry były zmuszone się rozdzielić. Te stanowiące personel szpitalny (w liczbie dwudziestu sześciu osób) poszły z chorymi i dzieliły ich los do końca. Sześć z nich zginęło podczas bombardowania dnia 31 sierpnia, bez wytchnienia służąc bliźniemu pomimo grożącego niebezpieczeństwa.

\footnotetext{
${ }^{24}$ M. Palm, dz. cyt., s. 41.

${ }^{25}$ S. Maria Paula - Józefa Dąbrowska, ur. 14 marca 1901 r. w Warszawie. Ukończyła studia ze specjalnością matematyki i fizyki. W 1936 r. wstąpiła do Zgromadzenia Sióstr Zmartwychwstanek. Dwa lata później, po ślubach, rozpoczęła pracę nauczycielską w szkole żoliborskiej. Tam też zastał ją wybuch powstania. Zmarła w Częstochowie dnia 14 maja 1990 r. w wieku lat 89 (w Zgromadzeniu 63 lata). Zob. M. L. Mistecka, Zmartwychwstanki charyzmat i dzieje 1891-1991, t. III, Lublin 2002, s. 178-179.

${ }^{26}$ E. Radziszewska, Dziennik Pielęgniarki z Powstania Warszawskiego, dz. cyt., s. 153-154.
} 
Po opuszczeniu klasztoru służbę objęła tam 1. kompania im. Walerego Wróblewskiego. Jednostka ta dysponowała niewielką liczbą broni, na którą składały się 2 karabiny maszynowe, 14 karabinów, 19 pistoletów maszynowych, 26 pistoletów, 1 granatnik przeciwpancerny, 140 granatów ręcznych i 47 butelek zapalających ${ }^{27}$. Wobec niewielkiej ilości uzbrojenia konieczne stało się umocnienie budynku na wszelkie możliwe sposoby. Do tego celu używano nawet wyposażenia domowego, co było kolejnym uszczerbkiem na majątku zgromadzenia. Przy klasztorze wzniesiono barykady powstańcze, tworząc najważniejszą linię obrony Żoliborza. Był to nieugięty punkt obronny tej części miasta, stąd dwie nazwy „Reduta Żoliborza” i „Twierdza Zmartwychwstanek”. Określenia te miały także związek z faktem, że klasztor z uwagi na rozmieszczenie stanowisk niemieckiej artylerii uchodził za bezpieczne miejsce: do 25 września pociski wroga trafiały najczęściej w górne kondygnacje budynku. Klasztor pełnił dodatkowo dwie istotne funkcje defensywne. Jako najwyższy budynek na tym terenie wydawał się dobrym miejscem do prowadzenia stałej obserwacji. Od 20 września był jednym z punktów do kierowania ogniem artylerii radzieckiej i polskiej ostrzeliwującej niemieckie pozycje z rejonu Pragi. Ponadto, przed przeniesieniem szpitala przebywającym tam rannym żołnierzom otuchy dodawała pełna wiary i ufności postawa sióstr.

Przez cały czas trwania Powstania budynek klasztorny był regularnie ostrzeliwany - do połowy września codziennie sprawdzano otwory po pociskach, których naliczono czterysta. Śmiertelnym zagrożeniem spowodowanym uderzeniami pocisków artyleryjskich były pożary. Zaledwie przez dwa dni (27-28 sierpnia) ugaszono 58 ognisk.

Przygniatająca przewaga niemieckiej broni ciężkiej i brak skutecznej broni do zwalczania czołgów i dział szturmowych uniemożliwiły dłuższe utrzymanie pozycji bojowych. Dnia 29 września nastąpiło opuszczenie „Twierdzy Zmartwychwstanek”. Wcześniej odbył się apel, w którym uczestniczyło 53 żołnierzy, w tym 18 lekko rannych, oraz 6 sanitariuszek - razem 59 osób ze 117 obrońców budynku. W obronie klasztoru poległo 21 żołnierzy i sanitariuszek, 3 żołnierzy ciężko rannych zmarło, 20 dostało się do niewoli. Za odwagę w odpieraniu ataków niemieckiego okupanta ppłk M. Niedzielski, pseudonim „Żywiciel”, odznaczył dwóch żołnierzy krzyżami Virtuti Militari, a szesnastu Krzyżami Walecznych. Był to najbardziej wyróżniony orderami oddział powstańczy tej części miasta ${ }^{28}$.

W tym miejscu warto podkreślić, że „Twierdza Zmartwychwstanek” była jedyną pozycją powstańczego Żoliborza niezdobytą przez Niemców, lecz opuszczoną na rozkaz, z uwagi na bezcelowość dalszej obrony. Co więcej, wojska niemieckie nie zajęły klasztoru nawet po zakończeniu Powstania, obawiając się, że budynek został dokładnie zaminowany, jak umyślnie przekonywali wzięci do niewoli powstańcy.

Nie sposób pominąc informacji o ogromnych stratach, jakie Zgromadzenie Sióstr Zmartwychwstanek poniosło w trakcie działań zbrojnych. Wymienić trzeba chociażby 10 zabitych sióstr, uszczerbek na zdrowiu kilkunastu innych oraz zrujnowany w $70 \%$ ma-

\footnotetext{
${ }^{27}$ Zob. M. L. Mistecka, Zgromadzenie Sióstr..., dz. cyt., s. 69.

${ }^{28}$ Tamże, dz. cyt., s. 89.
} 
jątek Zgromadzenia. Żoliborski gmach, choć po wojnie częściowo odbudowany, dzisiaj stanowi jedynie $1 / 3$ tego, co stało tu przed wojną.

Mimo niesprzyjających okoliczności oraz konieczności poniesienia olbrzymiego nakładu pracy i środków finansowych siostry nie poddały się, dlatego już na początku 1946 r. uczennice mogły wrócić do budynku na Krasińskiego, gdzie otworzono przedszkole, szkołę powszechną i pierwsze klasy gimnazjum. Już w kilka lat po wojnie szkoła dysponowała bogatym, jak na owe czasy, wyposażeniem w sprzęt dydaktyczny. Podziwem napełnia fakt, że siostry nie zrezygnowały z rozpoczętego wcześniej dzieła, ale zmobilizowały wszystkie siły, aby służyć dzieciom i młodzieży przez dalsze prowadzenie działalności oświatowej i wychowawczej.

W marcu 1958 r. podczas porządkowania ruin klasztoru wydobyto szkielety czterech poległych powstańców w wieku od 15 do 19 lat $^{29} .1$ kwietnia odprawiono mszę pogrzebową, po czym ekshumowane zwłoki złożono na Powązkowskim Cmentarzu Wojskowym. 6 maja w Liceum Zmartwychwstanek odbyła się uroczystość, uświetniona akademią z pieśniami powstańczymi, w czasie której przekazano Zgromadzeniu fragment sztandaru powstańczego, zdjętego z klasztoru w czasie ostrzału artylerii 29 września roku $1944^{30}$. Było to przypomnieniem dramatycznych dni Powstania Warszawskiego i odwagi tych, którzy mimo młodego wieku zdecydowali się oddać życie za wolność Ojczyzny. W tym miejscu można przywołać słowa s. Emilii Radziszewskiej, która wspominając swoją pielęgniarską posługę, zapisała: „Jeżeli powstanie w bezpośrednim swoim objawie było wybuchem miłości Ojczyzny i czynu dla niej, to szpital był przybytkiem jakiejś mistycznej atmosfery cierpienia, ofiary oraz cichej, a dumnej radości, że cierpi się za słuszną sprawę, za Polskę"31.

\section{Zakończenie}

Należy jeszcze raz podkreślić szczególny udział sióstr zmartwychwstanek w Powstaniu Warszawskim. Choć początkowo ich zadanie sprowadzało się do przygotowania łóżek i pomieszczeń dla rannych, z biegiem czasu objęło coraz to nowe obowiązki, podyktowane dramatycznym splotem wydarzeń i ogromnymi potrzebami bliźnich. Jakkolwiek wcześniej były one częściowo odizolowane od świata, w chwili wojny umiały dostosować się do trudnej sytuacji i współpracować z każdym dla dobra wszystkich.

Jak wykazała analiza dostępnych źródeł, siostry nie uchylały się od służby, ale z narażeniem własnego życia i spychając na drugi plan swoje własne potrzeby, ofiarnie posługiwały innym jako lekarki, pielęgniarki i pracownice zaplecza gospodarczego. Te wchodzące w skład personelu szpitala powstańczego do końca dzieliły swój los z tymi, którzy zostali powierzeni ich opiece. W chwilach grozy nie zapominały o klasztornym powołaniu, ale pozo-

\footnotetext{
${ }^{29}$ Jak podaje s. M. L. Mistecka, na podstawie dokumentów znalezionych przy ciałach zidentyfikowano następujące osoby: strzelca Gustawa Pawłowskiego (lat 15), żołnierza Bolesława Pilskiego ps. Pelikan (lat 16), sanitariuszkę Alicję Masłowską ps. Inka (lat 19). Zob. M. L. Mistecka, Zgromadzenie Sióstr..., dz. cyt., s. 125.

${ }^{30}$ Zob. M. L. Mistecka, Zgromadzenie Sióstr..., dz. cyt., s. 129.

${ }^{31}$ E. Radziszewska, Dziennik Pielęgniarki z Powstania Warszawskiego, dz. cyt., s. 87.
} 


\section{DIALOG RELIGII I KULTURY}

stały wierne zobowiązaniom życia zakonnego. Dzięki temu mogły być dla innych duchowymi przewodniczkami na drodze zbawienia przez cierpienie, odważnie podążając - zgodnie z mottem Zgromadzenia - „przez krzyż i śmierć do zmartwychwstania i chwały”. Postawą ufnej modlitwy dodawały rodakom otuchy i były dla nich zwiastunkami pokoju i nadziei. Bez wątpienia miały nieoceniony wkład w budowę „Powstańczej Reduty Żoliborza” „Twierdzy Zmartwychwstanek”, która dla pokoleń Polek i Polaków jest symbolem heroicznej walki i bohaterstwa okupionego ceną życia.

\section{BIBLIOGRAFIA:}

Mistecka M. L., Zmartwychwstanki charyzmat i dzieje 1891-1991, t. II, Lublin 2000 .

Mistecka M. L., Zmartwychwstanki charyzmat I dzieje 1891-1991, t. III, Lublin 2002.

Mistecka M. L., Zgromadzenie Sióstr Zmartwychwstania Pańskiego w czasie Powstania Warszawskiego, Lublin 1980.

Nekrologi Zmarłych Sióstr Zmartwychwstania Pana Naszego Jezusa Chrystusa od lipca do grudnia 1981-1956, t. II, mps.

Nekrolog s. M. Lucyny Misteckiej autorstwa s. Teofili Matusiak, mps.

Palm M., Widziane ze schronu, Częstochowa 2001.

Radziszewska E., Dziennik pielęgniarki z Powstania Warszawskiego, Częstochowa 1996.

\section{OAUTORCE:}

mgr lic. Joanna Pyszna - absolwentka Edukacji Medialnej i Dziennikarstwa oraz Teologii Duchowości Uniwersytetu Kardynała Stefana Wyszyńskiego w Warszawie. Zainteresowania badawcze: duchowość zakonna (w szczególności duchowość zmartwychwstańska) oraz teologia feministyczna.

Kontakt:joanna.pcp@gmail.com 
кuLTura- мeDia- TeoLogia

ISSN 2081-8971

$2017 \mathrm{nr} 30$, s. 174-183.

\title{
Tomistyczno-fenomenologiczna koncepcja personalizmu Karola Wojtyły wobec kryzysu wartości i wspótczesnych potrzeb edukacyjnych
}

\author{
Karol Woityla`s Thomistic-Phenomenological Concept of Personalism \\ Regarding the Crisis of Values and Contemporary Educational Needs.
}

\begin{abstract}
STRESZCZENIE:
DOMINUJĄCA WE WSPÓŁCZESNYM ŚWIECIE REDUKCJONISTYCZNA WIZJA CZŁOWIEKA SPROWADZA GO DO WYMIARU MATERIALNEGO I POMIJA NIEZBYWALNE PRAWO DZIECKA JAKO OSOBY DO WYCHOWANIA BĘDĄCEGO URZECZYWISTNIANIEM TKWIĄCEGO W NIM CZŁOWIECZEŃSTWA. DZIECKO JAKO UKŁAD ODNIESIENIA DLA SYSTEMU AKSJONORMATYWNEGO MUSI POSIADAĆ JASNO OKREŚLONY WZORZEC ZACHOWAŃ ORAZ FUNKCJONUJĄCY SYSTEM WZMACNIAJĄCY JEGO ZACHOWANIA POZYTYWNE ORAZ ZAPOBIEGAJACY ZACHOWANIOM NEGATYWNYM. POTRZEBA WIĘC DZIŚ BARDZIEJ NIŻ DOTYCHCZAS - WNIKLIWEGO ROZPOZNAWANIA I ODBUDOWANIA TRADYCJI PEDAGOGIKI PERSONALISTYCZNEJ ORAZ POWROTU JEJ ZAEOŻEŃ W PRAKTYCE WYCHOWAWCZEJ. ARTYKUŁ STANOWI PREZENTACJE TOMISTYCZNO-FENOMENOLOGICZNEJ KONCEPCJI PERSONALIZMU KAROLA WOJTYŁY JAKO PROPOZYCJE ZMIANY UPRAWIANEJ FILOZOFII
\end{abstract} WYCHOWANIA.

SŁOWA KLUCZOWE: AKSJOLOGIA, PERSONALIZM, WYCHOWANIE

\begin{abstract}
:
A REDUCTIONIST VISION OF MAN DOMINATING IN THE MODERN WORLD REDUCES HIM TO THE MATERIAL DIMENSION AND IGNORES THE INALIENABLE RIGHT OF CHILD AS A PERSON TO EDUCATION WHICH IS A REALISATION OF THE HUMANITY BEING INHERENT IN HIM / HER. A CHILD, AS A FRAME OF REFERENCE FOR THE AXIONORMATIVE SYSTEM, MUST HAVE A CLEARLY DEFINED BEHAVIOUR PATTERN AND A FUNCTIONING SYSTEM THAT STRENGTHENS HIS / HER POSITIVE BEHAVIOUR AND PREVENTS NEGATIVE BEHAVIOUR. THEREFORE, A THOROUGH DIAGNOSIS AND RESTORATION OF THE TRADITION OF PERSONALISTIC PEDAGOGY, AS WELL AS THE RETURN OF OF ITS ASSUMPTIONS IN EDUCATIONAL PRACTICE, IS NEEDED TODAY MORE THAN EVER. THIS PAPER IS A PRESENTATION OF KAROL WOJTYEA'S THOMISTIC-PHENOMENOLOGICAL CONCEPT OF PERSONALISM AS A PROPOSAL FOR CHANGING THE PHILOSOPHY OF EDUCATION BEING PRACTISED.

\section{KEYWORDS:}

AXIOLOGY, PERSONALISM, EDUCATION
\end{abstract}




\section{DIALOG RELIGII I KULTURY}

$\mathrm{K}$

ryzys edukacji można rozpatrywać w różnych aspektach i szukać wielu jego przyczyn. Jednym z aspektów jest kryzys wartości spowodowany m.in. uwikłaniem _educji w ideologiczne zalezności i wynikające z nich konsekwencje aksjologiczne. W poniższym tekście wskazuję na personalistyczną koncepcję człowieka jako na paradygmat umożliwiający wyprowadzenie edukacji z pustki aksjonormatywnej.

Szkodliwy wpływ ideologii neoliberalnej na system edukacyjny wprowadza m.in. rozchwianie tożsamościowe nauczycieli, redukowanie wszystkich podmiotów edukacji do jednostronnego wymiaru homo oeconomicus, awansowanie troski o siebie i własnej korzyści do rangi zasady moralnej, traktowanie wolności jednostki w sposób skrajnie indywidualistyczny. Filozof, Charles Taylor opisuje degradujące cechy współczesnej kultury i dzisiejszego społeczeństwa, wskazując na:
1) indywidualizm,
2) prymat rozumu instrumentalnego,
3) „łagodny despotyzm” władzy ${ }^{1}$.

Konsekwencją indywidualizmu jest pojawienie się społeczeństwa permisywnego, pokolenia narcystycznych egoistów, zamkniętych w kręgu własnej samotności, wszechobecny zanik wspólnotowego wymiaru życia, społecznych horyzontów działania, wspólnych celów i odpowiedzialności moralnej. Indywidualizm, zdaniem Taylora, poprzez zdegenerowanie horyzontów moralnych doprowadził do sytuacji, w której każdy posiada swoją własną moralność, w której obrzędy i normy społeczne ograniczono do ich roli czysto instrumentalnej, zdyskredytowano jakiekolwiek hierarchie społeczne, a ludzie utracili ,poczucie wyższego celu (...), szerszą wizję rzeczywistości, (...) skupili się na swoim własnym, indywidualnym życiu"².

Rozum instrumentalny to - według Taylora - „ten rodzaj racjonalności, którym posługujemy się, aby wyliczyć najbardziej ekonomiczny sposób wykorzystania środków prowadzących do danego celu"3, a więc maksymalne korzyści przy minimalnym wysiłku. Prymat rozumu instrumentalnego prowadzi do braku kryteriów moralnych, odpowiedzialności za słowo, nieobecność kategorii wspólnego dobra, wyrugowania celów, gdzie miarą słuszności i prawdy jest zamierzony efekt końcowy.

„Łagodny despotyzm” to taka forma władzy, która prezentuje się jako paternalistyczna, pryncypialna, „ojcowska”, ale - jak twierdzi Ch. Taylor - pozbawiona jest wszelkiej kontroli ze strony zatomizowanych, wycofanych do swego jednostkowego życia obywateli. Zanika aktywność obywatelska, pojedynczy człowiek zostaje pozostawiony sam sobie, czuje się bezradny i zdemobilizowany. Brak doświadczenia wspólnego działania prowadzi do wycofania i poczucia beznadziejności, z czego wynika alienacja, brak kontroli nad własnym losem i utrata wolności ${ }^{4}$. Istnieje więc potrzeba odzyskania fenomenu

\footnotetext{
${ }^{1}$ Ch. Taylor, Etyka autentyczności, Kraków 2002, s. 10-16.

2 Tamże, s. 10-11.

${ }^{3}$ Tamże, s. 11.

${ }^{4}$ Tamże, s. 88-93.
} 
wspólnotowości w celu uchronienia człowieka przed pułapką egoizmu, egocentryzmu i dehumanizacji stosunków społecznych, determinowanych mechanizmami rynkowymi i ideologią rozumu instrumentalnego. Na takiej etycznej bazie można budować poczucie wspólnoty społecznej, a edukacji nadać holistyczny wymiar.

$\mathrm{Na}$ uwikłanie edukacji w ideologię liberalizmu i demokrację zwraca również uwagę Andrzej Murzyn, wskazując na szkodliwe tego następstwa w rozwoju osobowości następnych pokoleń i jakości procesów wychowawczych ${ }^{5}$. Zauważa on konieczność uwolnienia edukacji z indoktrynacji i politycznych nacisków, aby w konstytucyjnie zagwarantowanej wolności sumienia i wyznania wychowywać dziecko. Systematyczną analizę i wyraźną krytykę neoliberalnej rzeczywistości społecznej i edukacyjnej zawarły w swoim dziele Eugenia Potulicka i Joanna Rutkowiak, wskazując m.in. na teoretyczne i społeczno-ekonomiczne konteksty neoliberalizmu oraz na neoliberalne upolitycznienie edukacji ${ }^{6}$.

Wyprowadzenie edukacji z kryzysu wartości należy - moim zdaniem - rozpocząć od zmiany paradygmatu, na którym wsparte są założenia programowe kształcenia i wychowania, a przede wszystkim od zmiany dotychczas uprawianej filozofii wychowania. Proponuję spojrzenie na edukację, szczególnie małego dziecka (ponieważ od niej zaczyna się instytucjonalny proces kształcenia i wychowania), w świetle filozofii (a także teologii) personalistycznej, przykładającej szczególną wagę do pojęcia osoby. Moja propozycja nie jest nowa, bowiem obserwuje się stały wzrost zainteresowania personalizmem, co widać po liczbie tekstów naukowych, które przyjmują kategorię osoby za pierwszoplanową w rozważaniach aksjologicznych. Pojęcie osoby stanowi kryterium oceny $\mathrm{w}$ wielu dziedzinach nauki, a w sporze pomiędzy liberalną i konserwatywną (czasami też socjalistyczną) ideologią zajmuje kluczowe miejsce przy wartościowaniu programów społecznych, w tym edukacyjnych.

\section{Personalizm}

Personalizm to „zespół koncepcji filozoficznych (wchodzących w zakres antropologii). Wspólnym punktem wyjścia wszelkich kierunków personalistycznych jest metafizyczne pojmowanie osoby jako autonomicznego bytu natury duchowej"7 lub inaczej: personalizm to „pogląd, że osoba ludzka i jej problemy są głównym przedmiotem filozofii człowieka" . Człowiek, zgodnie z tą koncepcją, jest osobą, bytem transcendentnym, świadomym siebie i realizującym się $\mathrm{w}$ relacji. Na podstawie tych słownikowych definicji można co prawda stwierdzić, że „dla personalisty punktem wyjścia i kluczem interpretacyjnym jest fenomen osoby, który mu się objawia"”, ale nie można wyprowadzić założenia, że persona

\footnotetext{
${ }^{5}$ A. Murzyn, Współczesna filozofia edukacji. Kluczowe kwestie, Kraków 2015, passim.

${ }^{6}$ E. Potulicka, J. Rutkowiak, Neoliberalne uwikłania edukacji, Kraków 2010, passim.

${ }^{7}$ L. Gawor, Personalizm [w:] Krajewski W., Słownik pojęć filozoficznych, Warszawa 1996, s. 149.

${ }^{8}$ S. Blackburn, Oksfordzki słownik filozoficzny, Warszawa 1997, s. 290.

${ }^{9}$ K. Guzowski, Personalizm polski na tle personalizmu europejskiego, w: Rusecki M. (red.), Personalizm polski, Lublin 2008, s. 442.
} 

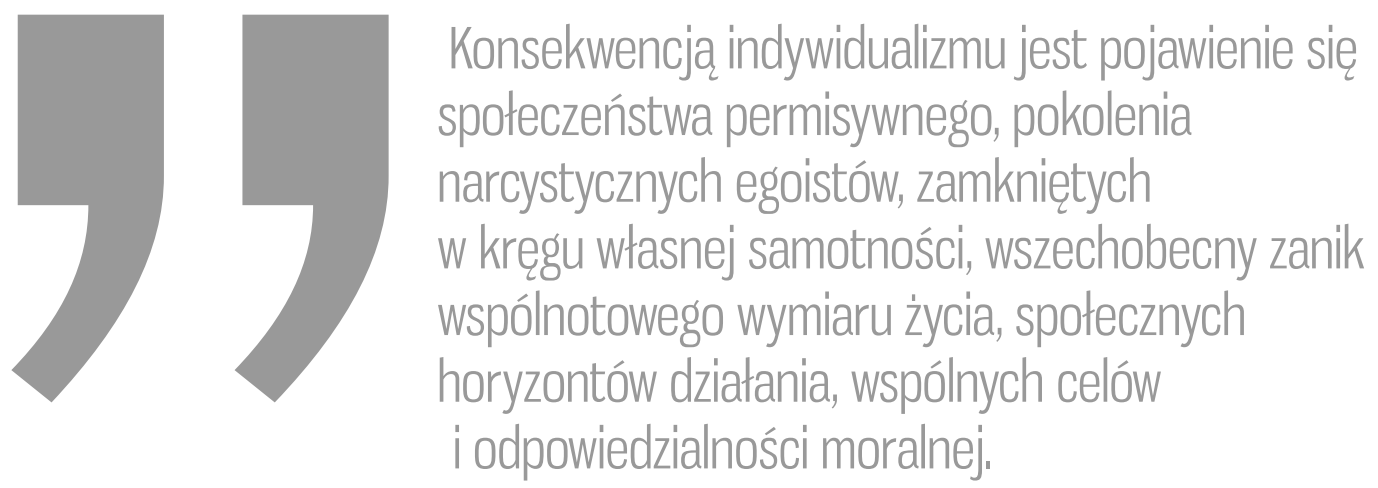

lizm jest koncepcją monolityczną i jednorodną. Personalizm jako kierunek filozoficzny wyodrębnia wiele różnych nurtów, których twórcy i przedstawiciele tworzą krąg myślicieli zajmujących się człowiekiem jako osobą ludzką. Barbara Kiereś pisze nawet, że „personalizm personalizmowi nierówny” oraz że „często uznaje się za personalizm «jakikolwiek pogląd, w którym akcentuje się (łącznie lub rozłącznie) transcendencję bytu ludzkiego nad światem przyrody, nad życiem społecznym i historią, gdzie mówi się o indywidualności, godności lub wartości człowieka, gdzie wskazuje się na jego wolność bądź rozumność (samoświadomość), czy wreszcie na cokolwiek, co wyróżnia człowieka w świecie i co ma świadczyć o jego wyjątkowości, niepowtarzalności, a nawet absolutności». Podkreślmy zatem, że nazywanie personalizmem każdej antropologii, która mówi o człowieku w jakichś superlatywach, jest nadużyciem tego słowa, ponieważ większość tych deklarowanych personalizmów to co najwyżej jakieś postulowane humanizmy"10.

Wspomnę więc tylko o niektórych wyodrębnionych nurtach personalizmu, skupiając się wyłącznie na koncepcji Karola Wojtyły. W ramach filozofii można wyróżnić personalizm: tomistyczny, egzystencjalno-fenomenologiczny, społeczny, aksjologiczny. Wyróżnia się także personalizm: metafizyczny, etyczny, społeczno-moralny, religijny, filozoficzny, teologiczny. Rozwój myśli filozoficznej doprowadził do wyodrębnienia personalizmu: fenomenologicznego, historycznego, egzystencjalistycznego, systemowego, neotomistycznego, filozoficzno-religijnego, spirytualistycznego, augustiańskiego. Te różne koncepcje personalizmu łączy wspólne podejście do autonomii, godności i zdolności wykraczania poza naturę i historię osoby. Podstawowa różnica między nurtami personalizmu tkwi w ich genezie.

Za twórcę nowożytnego personalizmu uznaje się Emmanuela Mouniera. Współczesny personalizm stanowił odpowiedź na problem antropologiczny wywołany przez indywidualizm liberalny i kolektywizm marksistowski ${ }^{11}$. Jak pisze Krzysztof Guzowski: „Nurty obu totalitarnych ideologii naruszyły dotychczasowy aksjomat wartości bytu człowieka. Stąd myśliciele różnych opcji filozoficznych zaczęli przeciwdziałać

\footnotetext{
${ }^{10}$ B. Kiereś, O personalizm w pedagogice. Studia i szkice z teorii wychowania, Lublin 2009, s. 23.

${ }^{11}$ K. Guzowski, Aktualność personalizmu, [w:] Granat W., Osoba ludzka. Próba definicji, Lublin 2006, s. 338.
} 
skutkom, ukazując jako podstawową wartość pojęcie i fenomen osoby ludzkiej, jej wolność oraz niezbywalne prawa" ${ }^{12}$. Zarówno indywidualizm, jak i kolektywizm zagrażały godności osoby ludzkiej, stąd pojawiła się konieczność przyjęcia zasady (personalistycznej), że osoba nie jest środkiem do celu, lecz celem samym w sobie, że człowiek jest najwyższą wartością, posiada wolną wolę i tylko on - w sensie ontologicznym - jest prawdziwy.

Myśl personalistyczna kształtująca się na przestrzeni wieków czerpała inspiracje zarówno z myśli greckiej (sofiści, Arystoteles, Sokrates), jak i chrześcijańskiej (średniowieczne nauki św. Augustyna i św. Tomasza). Po raz pierwszy terminu „personalizm” (der Personalismus) użył Friedrich Daniel Schleiermacher, niemiecki teolog, filozof i filolog klasyczny, w swojej książce Über die Religion. Reden an die Gebildeten unter ihren Verächtern ${ }^{13}$, napisanej w 1799 roku w formie osobistego wyznania wiary. F. Schleiermacher użył tego terminu, aby określić koncepcję Boga osobowego dla przeciwstawienia panteizmowi. Ontologiczne (teoria o bycie - dociekanie natury wszystkiego, cokolwiek istnieje) pojęcie osoby poddano z czasem krytycznej refleksji, wskazując na zasadność ujmowania jej w kategoriach fenomenologicznych (teoria poznania - nie znamy innych przedmiotów, jak tylko realne). Pojawiła się wówczas wyraźna różnica pomiędzy metafizycznym, teologicznym personalizmem a personalizmem, który określany jest jako personalizm historyczny. W tym pierwszym personalizmie mówi się o człowieku jako osobie, gdyż jest on w relacji do Boga, mając z Nim ową oryginalną łączność manifestującą się zwłaszcza w jego sumieniu. W personalizmie historycznym człowiek jest osobą, ponieważ ma on swoją wartość zaznaczającą się i zdobytą w historii; w perspektywie czasowej staje się on osobą i ten proces stawania się osobą jest nieskończony i ciągly. W zakresie podkreślania wartości i godności osoby ludzkiej personalizm bywa identyfikowany z tradycją chrześcijańską. Pod wpływem interpretacji myśli św. Tomasza z Akwinu ukształtował się personalizm katolicki, za twórców którego uważa się Jacquesa Maritaina (personalizm esencjonalny), Emmanuela Mouniera (personalizm społeczny). Przedstawicielami tego nurtu personalizmu w Polsce są m.in.: Mieczysław Gogacz, Mieczysław A. Krąpiec, Józef Tischner, Karol Wojtyła.

\section{Koncepcja personalizmu Karola Wojtyły}

Szczególnie bliska refleksji Karola Wojtyły była koncepcja filozoficzna przedstawiona przez J. Maritaina, który niejako na nowo odkrył idee personalistyczne św. Tomasza z Akwinu. W filozofii tomistycznej po raz pierwszy istnienie potraktowano jako realny element ontologiczny. Powstałe później odmiany tomizmu odmiennie rozumiały to, czym jest ten element i jaka jest jego rola. Wyróżnia się m.in. tomizm tradycyjny, lowański, transcendentalny, egzystencjalny, konsekwentny. Karol Wojtyła uprawiał w etyce tomizm transcendentalny, który powstał na gruncie tomizmu lowańskiego i,

\footnotetext{
${ }^{12}$ Tenże, Personalizm polski na tle personalizmu europejskiego, dz. cyt., s. 441.

${ }^{13}$ Polskie tłumaczenie: F. Schleiermacher, Mowy o religii do ludzi wykształconych spośród tych, którzy nią pogardzają, Kraków 1995.
} 


\section{DIALOG RELIGII I KULTURY}

w którym przedmiotem filozofii jest świadomość, a postępowanie badawcze polega na ustaleniu treści świadomości i ujawnianiu zawartych tam warunków apriorycznych poznania. Wszystkie opisane odmiany tomizmu mają wspólne podłoże, którym jest filozofia tomistyczna oraz przyjęta w niej koncepcja bytu jako istniejącego. Natomiast różnią się głównie sposobem rozumienia istnienia w ogólnej strukturze bytu. Prowadzi to do pewnych różnic w założeniach metafizycznych oraz przejawia się w budowanych koncepcjach osoby. Z kolei założenia metafizyczne i antropologiczne, na których opiera się etyka, wyznaczają charakterystyczne dla różnych odmian tomizmu cechy systemów etycznych. Wojtyła zetknął się z filozofią w ujęciu tomistycznym w czasie studiów seminaryjnych. W kolejnych latach zapoznał się z dziełami fenomenologicznymi (głównie twórcy fenomenologii, Maxa Schelera), wykorzystując potem narzędzia fenomenologii we własnych koncepcjach filozoficznych (fenomenologia jest kierunkiem filozoficznym, polegającym na opisie i oglądzie tego, co bezpośrednio jest dane). Personalizm etyczny Karola Wojtyły łączy tomizm (obiektywność osoby) i fenomenologię (subiektywność osoby), stąd na gruncie polskim Wojtyła najpełniej rozwinął tomistyczno-fenomenologiczną koncepcję personalizmu. Katarzyna Wrońska wskazuje na jej trzy cechy:

1. osobocentryzm; każdy człowiek jest osobą, która przez nikogo nie może być traktowana jako narzędzie do realizacji własnych celów;

2. perfekcjoryzm; koncepcja doskonałości moralnej jako podstawowego celu rozwoju człowieka;

3. normatywizm; oznacza w wychowaniu stałą obecność norm i powinności; źródłowymi wartościami bezwzględnymi jest dobro i prawda jako zasada bytu ${ }^{14}$.

Osobocentryzm przejawia i realizuje się w sformułowanej przez Wojtyłę normie personalistycznej zakładającej, że jedynym odniesieniem do osoby jest miłość. Każdy człowiek jest przede wszystkim osobą, ma swój cel i nie może być dla nikogo narzędziem do celu. Osoba ma wewnętrzną wartość, która określana jest jako godność. Osoba w tym rozumieniu to nie tylko podmiot, ale także sprawca czynu, podmiot podejmujący świadome działanie; „,czyn stanowi szczególny moment ujawnienia osoby” ${ }^{15}$. Człowiek spełniający czyn jest realnym sprawcą dobra lub zła moralnego. W filozofii Wojtyły osobowy byt niesie za sobą akceptację powinności uznania godności osoby, która ma w sobie tendencję do czynienia dobra (i zła). Doświadczenie osoby ludzkiej jest doświadczeniem moralnym, które niesie za sobą przeżycie powinności afirmacji osoby ze względu na jej godność. Źródłem poznania rzeczywistości osoby jest czyn, a „szczególniejszym jeszcze źródłem jest - moralność w aspekcie dynamicznym, czyli egzystencjalnym"16. Cecha osobocentryzmu jest szczególnie istotna w relacji wychowawca/nauczyciel/rodzic - dziec-

\footnotetext{
${ }^{14}$ K. Wrońska, Karola Wojtyły personalistyczna filozofia wychowania, w: Adamski F. (red.), Wychowanie na rozdrożu. Personalistyczna filozofia wychowania, Kraków 1999, s. 187-193.

${ }^{15}$ K. Wojtyła, Osoba i czyn, Kraków 1985, s. 15.

${ }^{16}$ Tamże, s. 18.
} 
ko/uczeń, kiedy to występuje niesymetryczność relacji i możliwość arbitralności decyzji. W aspekcie indywidualnym występuje afirmacja osoby, natomiast w aspekcie społecznym - afirmacja człowieczeństwa.

Drugą cechą tomistyczno-fenomenologicznej koncepcji personalizmu Karola Wojtyły jest perfekcjoryzm, podstaw którego w etyce poszukiwał on już w latach pięćdziesiątych ubiegłego wieku. Pisał wówczas, że perfekcjoryzm „kładzie nacisk na stawanie się człowieka lepszym przez każdy dobry czyn” w odróżnieniu od perfekcjonizmu, który „mówi ogólnie o doskonaleniu się moralnym człowieka”. O perfekcjoryzmie w etyce można mówić, ,jeżeli etyka uwydatnia to, że czyn dobry istotnie doskonali spełniającego ów czyn człowieka" ${ }^{17}$. Perfekcjoryzm zwraca uwagę na potrzebę obecności w procesie wychowania ideałów i wzorów osobowych oraz niekwestionowanych autorytetów. Wzór osobowy jest nośnikiem wartości do naśladowania, zaś autorytet strzeże wartości i wymaga posłuszeństwa od tych, którzy podążają za wzorem osobowym. „Szacunek należny autorytetowi to postawa uformowana przede wszystkim przez działanie rozumu i woli człowieka, natomiast w relacji do wzoru osobowego przeważa zaangażowanie emocjonalno-uczuciowe"18. Wzory osobowe przyczyniają się do udoskonalania (się) człowieka przez wartościowe czyny, które naśladuje.

Perfekcjoryzm nie utożsamia się z normatywizmem etyki, który stanowi kolejną cechę personalizmu Wojtyły. Normatywizm zakłada obecność norm i powinności w wychowaniu oraz określa, co jest „,dobre lub złe, jaki czyn jest przedmiotowo dobry lub zły, abstrahując od tego, że czyn ów przyczynia się do udoskonalenia człowieka spełniającego go albo też do jakiejś dewaluacji jego człowieczeństwa" ${ }^{19}$. Normatywizm podkreśla, że wychowanie służy wprowadzeniu dziecka w świat wolności, odpowiedzialności i miłości, w którym to świecie człowiek osiąga dojrzałość osobową. Nowy cywilizacyjny model funkcjonowania społeczeństwa, jakim jest konsumpcjonizm, nakazuje człowiekowi oddawać kult maksymalizacji własnych korzyści, merkantylizacji i wyrachowaniu, hołdować zasadzie: „wszystko można sprzedać” i „,wszystko można kupić”. Wobec tworzenia się „homo consumens” należałoby przyjąć zasadę normatywizmu oraz wrócić do tych idei i koncepcji wychowania, które: a) kształtują wolności, b) uczą odpowiedzialności, c) otwierają na miłość.

Wskaźnikami personalistycznej orientacji wychowania wyprowadzonej z koncepcji Wojtyły są więc: postrzeganie osoby, teleologia wychowania i relacje wobec otaczającej rzeczywistości. Człowiek jako osoba konstytuuje się poprzez swoje czyny i jako obdarzony godnością osobową pozostaje w pewności i przeświadczeniu, że tylko godziwość celu działania człowieka uzasadnia zastosowanie tego celu wobec drugiego. Celem wychowania jest zinterioryzowanie źródłowych wartości i otworzenie przed wychowankiem pól wolności i odpowiedzialności. W personalistycznym wychowaniu wolność ro-

\footnotetext{
${ }^{17}$ K. Wojtyła, W poszukiwaniu podstaw perfekcjoryzmu w etyce, „Roczniki Filozoficzne KUL” 1955-57 nr 5, z. 4 , s. 303 .

${ }^{18}$ K. Wrońska, Karola Wojtyły personalistyczna filozofia wychowania, dz. cyt., s. 193.

${ }^{19} \mathrm{~K}$. Wojtyła, W poszukiwaniu podstaw perfekcjoryzmu w etyce, dz. cyt., s. 303-304.
} 


\section{DIALOG RELIGII I KULTURY}

zumiana jest jako umiejętność opowiedzenia się za dobrem, jako samostanowienie, władanie sobą i odpowiedzialny wybór w działaniu. Każdy wybór angażuje uczucie (jako wzbudzanie poczucia odpowiedzialności), rozum (jako refleksja nad odpowiedzialnością) i wolę (jako zgoda na podjęcie odpowiedzialności). „Istotną racją wyboru oraz samej zdolności wybierania nie może być nic innego, jak swoiste odniesienie do prawdy, które wnika w intencjonalność chcenia i tworzy jakby jego zasadę wewnętrzną"20. Dzięki odniesieniu do prawdy, wola w porządku intencjonalnym, czyli w porządku chcenia przedmiotów, zyskuje niezależność, czyli wolnośćci. Wolność nie jest celem samym w sobie; wolność - zdaniem Karola Wojtyły - jest dla miłości: „Osoba jest takim dobrem, że właściwe i pełnowartościowe odniesienie do niej stanowi tylko miłość”22, zaś „miłość angażuje wolność i napełnia ją tym, do czego z natury lgnie wola - napełnia ją dobrem" ${ }^{23}$. W związku z tym wolność, której celem jest miłość, jest kształtowana i realizowana przez podporządkowanie się prawdzie, a nie poprzez podporządkowanie sobie prawdy ${ }^{24}$. Najwyższym stadium wolności człowieka jest darowanie samego siebie. Taka jest misja i zadanie wychowawcy wobec wychowanka w tomistyczno-fenomenologicznej koncepcji personalizmu Karola Wojtyły.

\section{Zakończenie}

Personalizm jako filozoficzna podstawa wychowania przyjmuje za cel wychowania pełny rozwój osoby, jej spełnienie w ludzkiej egzystencji. Wychowanie jest ustawicznym procesem doskonalenia się osobowego. Podstawą doskonałości osobowej człowieka jest - jak pisze Franciszek Adamski - jego stosunek do „prawdy o człowieku w jego wymiarze przyrodzonym i nadprzyrodzonym, indywidualnym i społecznym; sensie jego istnienia i odniesieniu do Transcendencji; prawdy o otaczającym go świecie widzialnym i niewidzialnym i jego miejscu w tym świecie" ${ }^{25}$. W ujęciu tomistyczno-fenomenologicznym człowiek jest osobą, bytem transcendentnym, świadomym siebie i realizującym się w relacji wolności i miłości. Szczególnie istotne znaczenie dla wychowania ma uznanie godności osobowej dziecka, która jest immanentnie wpisana w jego człowieczeństwo. Godność wskazuje, że - jak pisze Tadeusz Biesaga - to osoba jest wartością wartości, a nie wartości w osobie stanowią o jej osobowej godności ${ }^{26}$. „Wartość samej osoby należy wyraźnie odróżnić od różnych wartości, które tkwią w osobie. Są to

\footnotetext{
${ }^{20} \mathrm{~K}$. Wojtyła, Osoba i czyn oraz inne studia antropologiczne. Seria: Człowiek i moralność, t. 4, T. Styczeń, J. W. Gałkowski, A. Rodziński, A. Szostek (red.), Lublin 1994, s. 181.

${ }^{21}$ Tamże, s. 182-183.

${ }^{22}$ K. Wojtyła, Miłość i odpowiedzialność. Seria: Człowiek i moralność, t. 1, T. Styczeń, J. W. Gałkowski, A. Rodziński, A. Szostek (red.), Lublin 1982, s. 42.

${ }^{23}$ Tamże, s. 120.

${ }^{24} \mathrm{~K}$. Wojtyła, Osoba i czyn oraz inne studia antropologiczne, dz. cyt., s. 189.

${ }^{25}$ F. Adamski (red.), Wychowanie na rozdrożu. Personalistyczna filozofia wychowania, Kraków 1999, s. 8.

${ }^{26}$ T. Biesaga, Godność a wolność w antropologii Karola Wojtyły, w: Hołub G., Duchliński P. (red.), Ku rozumieniu godności człowieka, Kraków 2008, s. 76.
} 
wartości wrodzone lub nabyte (...). Wartość osoby związana jest z całym bytem osoby" ${ }^{27}$. Skoro ze swej natury człowiek jest bytem osobowym, to przysługuje mu właściwa osobie - podmiotowość. W koncepcji Wojtyły podmiotowość osoby jest rozważana w kontekście czynu ludzkiego stanowiącego formę uzewnętrznienia osoby, która jest podmiotem istnienia i działania, także działania moralnego. Osoba nie ,jest”, lecz „staje się” poprzez czyny i realizowane w nich dobro lub zło moralne. Doświadczenie czynu stoi u podstaw całościowej wiedzy o człowieku. W sensie ontycznym człowiek z natury jest „kimś” bez względu na czyny, jakich jest sprawcą, natomiast w sensie moralnym staje się „kimś” poprzez spełnianie konkretnych czynów. W sensie ontycznym człowiek zaopatrzony jest w godność osobową i w takim rozumieniu człowieka jest zakorzenione jego rozumienie aksjologiczne, zaś w sensie etycznym człowiek dysponuje godnością osobowościową, zależną od jakości spełnianych czynów. Jedynym wartościowym odniesieniem do bytu osobowego jest miłość jako najpełniejsza relacja osobowa. Jest ona możliwa bez redukowania własnej wolności.

W takim ujęciu osoby staje się ona kluczem do syntetycznego rozumienia rzeczywistości, także pedagogicznej. Barbara Kiereś pisze, że „,zaznacza się pilna potrzeba przypomnienia i krytycznego odbudowania tradycji pedagogiki personalistycznej oraz przywrócenia jej osiągnięć praktyce wychowawczej” ${ }^{28}$, co potwierdza wywód w powyższym tekście.

\section{BIBLIOGRAFIA:}

Adamski F. (red.), Wychowanie na rozdrożu. Personalistyczna filozofia wychowania, Wydawnictwo Uniwersytetu Jagiellońskiego, Kraków 1999.

Biesaga T., Godność a wolność w antropologii Karola Wojtyły, w: Hołub G., Duchliński P. (red.), Ku rozumieniu godności człowieka, Wydawnictwo Naukowe Papieskiej Akademii Teologicznej, Kraków 2008.

Blackburn S., Oksfordzki słownik filozoficzny, Książka i Wiedza, Warszawa 1997.

Gawor L., Personalizm, w: Krajewski W., Słownik pojęć filozoficznych, Wydawnictwo Naukowe Scholar, Warszawa 1996.

Guzowski K., Aktualność personalizmu, w: Granat W., Osoba ludzka. Próba definicji, Wydawnictwo KUL, Lublin 2006.

Guzowski K., Personalizm polski na tle personalizmu europejskiego, w: Rusecki M. (red.), Personalizm polski, Wydawnictwo KUL, Lublin 2008.

Kiereś B., O personalizm w pedagogice. Studia i szkice z teorii wychowania, Fundacja Servire Veritati Instytut Edukacji Narodowej, Lublin 2009.

Murzyn A., Współczesna filozofia edukacji. Kluczowe kwestie, Oficyna Wydawnicza Impuls, Kraków 2015.

\footnotetext{
${ }^{27}$ K. Wojtyła, Miłość i odpowiedzialność, dz. cyt., s. 110.

${ }^{28}$ B. Kiereś, O personalizm w pedagogice, dz. cyt., s. 12.
} 


\section{DIALOG RELIGII I KULTURY}

Potulicka E., Rutkowiak J., Neoliberalne uwikłania edukacji, Oficyna Wydawnicza Impuls, Kraków 2010.

Schleiermacher F., Mowy o religii do ludzi wykształconych spośród tych, którzy nią pogardzają, Wydawnictwo Znak, Kraków 1995.

Taylor Ch., Etyka autentyczności, Wydawnictwo Znak, Kraków 2002.

Wojtyła K., W poszukiwaniu podstaw perfekcjoryzmu w etyce, „Roczniki Filozoficzne KUL” $1955-57 \mathrm{nr}$ 5, z. 4, s. 303-317.

Wojtyła K., Miłość i odpowiedzialność. Seria: Człowiek i moralność, t. 1, Styczeń T., Gałkowski J. W., Rodziński A., Szostek A. (red.), Towarzystwo Naukowe KUL, Lublin 1982.

Wojtyła K., Osoba i czyn, Polskie Towarzystwo Teologiczne, Kraków 1985.

Wojtyła K., Osoba i czyn oraz inne studia antropologiczne. Seria: Człowiek i moralność, t. 4, Styczeń T., Gałkowski J. W., Rodziński A., Szostek A. (red.), Towarzystwo Naukowe KUL, Lublin 1994.

Wrońska K., Karola Wojtyły personalistyczna filozofia wychowania, w: Adamski F. (red.), Wychowanie na rozdrożu. Personalistyczna filozofia wychowania, Wydawnictwo Uniwersytetu Jagiellońskiego, Kraków 1999.

\section{OAUTORCE:}

dr Małgorzata Kunicka, adiunkt w Katedrze Wczesnej Edukacji Instytutu Pedagogiki, WH Uniwersytet Szczeciński; doktor nauk humanistycznych w zakresie pedagogiki; autorka monografii pt. „Teleologiczne orientacje nauczycieli”, Wydawnictwo Naukowe „Impuls”, Kraków 2005 oraz kilkunastu artykułów w czasopismach punktowanych i 17 rozdziałów w monografiach; zainteresowania naukowe oscylują wokół społeczno-edukacyjnych relacji w szkole rozpoznawanych w paradygmacie antropologii personalistycznej.

Kontakt:mkunicka@op.pl. 
кuLTura - мeDia- TeoLogia

ISSN 2081-8971

2017 nr 30, s. 184-209.

Jacek Śliwak, Katolicki Uniwersytet Lubelski

Beata Zarzycka, Katolicki Uniwersytet Lubelski

Dominika Zarosińska, Katolicki Uniwersytet Lubelski

Urszula Piaszczak, Katolicki Uniwersytet Lubelski

\section{Religjjność a komunikacja w małżeństwie}

Religiosity and communication in marriage

\begin{abstract}
STRESZCZENIE:
NINIEJSZY ARTYKUE TRAKTUJE O RELIGIJNOŚCI W ODNIESIENIU DO KOMUNIKACJI MAEŻEŃSKIEJ. OPISUJĄC POJĘCIE RELIGIJNOŚCI ODNIESIONO SIĘ DO WIELOFUNKCYJNEGO MODELU RELIGIJNOŚCI STEFANA HUBERA, KTÓREGO OPERACJONALIZACJE STANOWI SKALA Centralności Religijności C-15 . KomunikaCja MAEŻEŃSKA, Z KOLEI, UJĘTA ZOSTAEA Z PERSPEKTYWY STRUKTURY ZAPROPONOWANEJ PRZEZ KAŹMIERCZAK I PLOPE , CZEGO OPERACJONALIZACJA JEST KwESTIONARIUSZ KoMUNIKACJI MAEŻEŃSKIEJ (KKM). W BADANIU UDZIAE WZIĘŁO 100 OSÓB (50 KOBIET I 50 MĘŻCZYZN), BĘDĄCYCH W ZWIĄZKACH MAEŻEŃSKICH. GŁÓWNA HIPOTEZA MÓWI O ISTNIENIU ZWIĄZKÓW ISTOTNYCH STATYSTYCZNIE MIĘDZY CENTRALNYM

USYTUOWANIEM RELIGIJNOŚCI W POZNAWCZEJ STRUKTURZE OSOBOWOŚCI I POZYTYWNĄ KOMUNIKACJĄ W MAŁŻEŃSTWIE. UZYSKANE WYNIKI POZWOLIEY NA CZĘSCIOWE POTWIERDZENIE STAWIANYCH HIPOTEZ.
\end{abstract}

SLOWA KLUCZOWE: RELIGIJNOŚĆ, KOMUNIKACJA, MAEŻEŃSTWO

\begin{abstract}
:
THIS PAPER CONCERNS RELIGIOSITY IN REFERENCE TO COMMUNICATION IN MARRIAGE. THE NOTION OF RELIGIOSITY WAS DESCRIBED WITH REFERENCE TO THE Multifunctional Model of Religiosity C-15. COMMUNICATION IN MARRIAGE WAS CONSIDERED IN THE LIGHT OF THE STRUCTURE PROPOSED BY KAŹMIERCZAK AND Plopa, WHAT WAS OPERATIONALISED IN THE Questionnaire of COMMUNICATION IN MARRIAGE. 100 MARRIED PEOPLE ( 50 WOMEN AND 50 MEN) PARTICIPATED IN THE SURVEY. THE MAIN HYPOTHESIS IS THAT THERE IS STATISTICALLY SIGNIFICANT CORRELATION BETWEEN CENTRAL LOCATION OF RELIGIOSITY IN THE COGNITIVE STRUCTURE OF PERSONALITY AND POSITIVE COMMUNICATION IN MARRIAGE. THE SURVEY'S RESULTS ALLOWED TO PARTIALLY CONFIRM THE HYPOTHESES.
\end{abstract}

\section{KEYWORDS:}

RELIGIOSITY, COMMUNICATION, MARRIAGE 
$\mathrm{R}$

eligijność na gruncie psychologii rozumiana jest jako indywidualne odniesienie człowieka do rzeczywistości transcendentnej i towarzyszące temu procesy psyróż nych koncepcji teoretycznych. Każde z podejść charakteryzuje się odmiennymi założeniami odnośnie do interpretacji zjawiska religijności, akcentując inne jej wartości czy funkcje.

Do poznawczego nurtu psychologii religii zalicza się m.in. teorię autorstwa Stefana Hubera, który definiuje religijność jako wyraz pewnego systemu konstruktów religijnych człowieka. Oznacza ona zdolność do uwzględniania znaczeń religijnych przy przetwarzaniu rzeczywistości ${ }^{2}$.

Wielofunkcyjny model religijności stanowi syntezę koncepcji dojrzałej religijności Allporta (wyróżniającej religijność zewnętrzną i wewnętrzną) oraz wielowymiarowej struktury religijności, autorstwa Glocka i Starka ${ }^{4}$, przy jednoczesnym korzystaniu z teorii konstruktów osobistych Kelley'ego ${ }^{5}$. Huber ujmuje religijność zarówno w aspekcie jej funkcji treściowej, jak i motywacyjnej. Oznacza to, że religijność pojmowana jako konstrukt osobisty, w strukturze osobowości może zajmować miejsce centralne lub peryferyjne. Osobowość determinuje styl myślenia, postrzegania rzeczywistości czy zachowania. Jeśli więc religijność ujmowana jest jako jeden $\mathrm{z}$ aspektów osobowości, ma zatem ona moc regulacyjną w stosunku do zachowania się jednostki. Im ważniejszą pozycję zajmuje dany konstrukt (np. religijność), tym większy wpływ wywiera on na funkcjonowanie człowieka oraz intensywność jego zachowań i przeżyć. W praktyce oznacza to, że im bardziej centralną pozycję w osobowości zajmuje konstrukt religijności, tym jednostka częściej kieruje się w swoim życiu regułami i dogmatami wyznawanej wiary. Nie oznacza to jednak, że jedynym wyznacznikiem religijności jest częstotliwość ${ }^{6}$. Należy bowiem uwzględniać także „funkcję pozycji i treści religijnego systemu znaczeń w hierarchicznym systemie konstruktów osobistych"7. Ważny jest ponadto aspekt motywacyjny ludzkich działań. Huber twierdzi, że motywacja wewnętrzna wiąże się z nadrzędną pozycją konstruktów religijnych, zaś motywacja zewnętrzna z pozycją podporządkowaną. W sytuacji, gdy religia zajmuje centralną pozycję w poznawczej strukturze osobowości człowieka, można mówić o jej autonomicznym charakterze. Przejawia się ona wtedy $\mathrm{w}$ religijnym obrazie siebie i konsekwencjach, jakie wywiera w życiu codziennym, w postawach i zachowaniach jednostki. Oznacza to, że osoby z nadrzędną pozycją religii we

\footnotetext{
${ }^{1}$ Zob. D. Krok, Religijność a jakość życia w perspektywie mediatorów psychospołecznych, Opole 2009.

${ }^{2}$ Zob. Tamże; B. Zarzycka, art. cyt., s. 231-261.

${ }^{3}$ Zob. G. Allport, Osobowość i religia, Warszawa 1988.

${ }^{4}$ Zob. Ch.Y. Glock, R. Stark, Religion and society in tension, Chicago 1965; R. Stark, Ch.Y. Glock, American

Piety: The nature of religious commitment. Berkeley, Los Angeles, London 1970.

${ }^{5}$ Zob. G. Kelly, The psychology of personal constructs, New York 1955.

${ }^{6}$ Por. B. Zarzycka, art. cyt., s. 231-261.

${ }^{7}$ Por. Tamże, s. 235.
} 
własnym systemie konstruktów osobistych, będą podejmowały decyzje i zachowania zgodne z uznawanymi przez siebie dogmatami wiary. Zachowania te nie będą spontaniczne ani przypadkowe, ale ustrukturyzowane, bowiem podyktowane wyznawanymi wartościami i normami, wypływającymi z religii. Wyznawana religia będzie miała zatem wpływ na niemalże wszystkie dziedziny życia danego człowieka, a więc na pracę, postrzeganie własnej i cudzej płciowości, zachowania przejawiane wobec innych, a co za tym idzie także na styl komunikowania się ze współmałżonkiem.

Mając w pamięci naukę Kościoła katolickiego w kwestii poszanowania współmałżonka i realizacji małżeńskich zobowiązań względem niego, zakłada się, że osoby kierujące się zasadami wyznawanej religii, dla których wiara jest istotnym elementem życia, będą charakteryzowały się centralną religijnością, co w dalszej konsekwencji będzie istotnie regulować ich funkcjonowanie, m.in. w relacji małżeńskiej.

Komunikacja małżeńska rozpatrywana jest z perspektywy struktury, którą zaproponowali Kaźmierczak i Plopa ${ }^{8}$, a która wskazuje jej trzy następujące kategorie: komunikację wspierającą, zaangażowaną i deprecjonującą. Wsparcie charakteryzuje się okazywaniem szacunku partnerowi przez docenianie jego wysiłków, przejawianie zainteresowania jego problemami czy potrzebami, a także aktywne uczestniczenie w procesie wspólnego rozwiązywania konfliktów. Troska o partnera jest zatem przejawiana nie tylko w chwilach trudnych, ale także w różnych sytuacjach dnia codziennego. Zaangażowanie to umiejętność okazywania sobie uczuć, podkreślanie wyjątkowości i ważności partnera, tworzenie atmosfery wzajemnego zrozumienia i bliskości, urozmaicanie codziennej rutyny oraz zapobieganie (lub przynajmniej próby przeciwdziałania) konfliktom. Natomiast deprecjacja odnosi się do przejawiania różnego rodzaju agresji wobec partnera, braku poszanowania jego godności osobistej, dążenia do zdominowania i kontrolowania go ${ }^{9}$.

Wspólne życie wymaga otwartej i szczerej komunikacji, która dąży do ustalenia jednego punktu widzenia, planu działania przy unikaniu niepotrzebnych konfliktów. Dla małżonków porozumiewanie się jest szczególnie ważne, gdyż to od niego, w dużej mierze, zależy powodzenie i sukces małżeński, a co za tym idzie, trwałość relacji ${ }^{10}$. Na dobrą komunikację składa się wiele czynników, wśród których istotna jest także zgodność postaw religijnych, co obecnie wydaje się być niedoceniane, a nawet ignorowane. Jak wykazują badania, adolescenci, w momencie wyboru partnera, nie interesują się raczej jego religijnością ${ }^{11}$. Przytoczone studium jest co prawda odległe w czasie, jednak

\footnotetext{
${ }^{8}$ Zob. M. Kaźmierczak, M. Plopa, dz. cyt.

${ }^{9}$ Zob. Tamże.

${ }^{10}$ Por. K. Adamczyk, Inteligencja emocjonalna i system wartości małżonków a ich komunikacja interpersonalna, „Kwartalnik Naukowy” $2013 \mathrm{nr} 2$ (13), s. 72-101; R.B. Adler, L.B. Rosenfeld, R.F. Proctor, Relacje interpersonalne. Proces porozumiewania się, Poznań 2006; S. Frydrychowicz, Komunikacja interpersonalna jako wartość rozwojowa w rodzinie, w: B. Harwas-Napierała (red.), Rodzina jako wartość rozwojowa, Poznań 2009, s. 91-107; M. Plopa, Psychologia rodziny. Teoria i badania, Elbląg 2004; J. Rostowski, Zarys psychologii małżeństwa. Psychologiczne uwarunkowania dobranego związku małżeńskiego, Warszawa 1987.

${ }^{11}$ Por. J. Kupczyk, Ideał przyszłego małżonka w oczach młodzieży, „Ruch pedagogiczny” 1974 nr 6, s. 829.
} 


\section{DIALOG RELIGII I KULTURY}

analogiczne tendencje rozwojowe społeczeństwa zaznaczają się również w latach współczesnych, zdając się przybierać na sile. Należy zaznaczyć, iż ignorowanie kwestii kompatybilności wyznawanej religii stanowi niezwykle powierzchowne podejście do związku, które z dużym prawdopodobieństwem przyniesie wiele poważnych, negatywnych konsekwencji w przyszłości relacji. Jak wiadomo z badań Braun-Gałkowskiej ${ }^{12}$ czy Walesy $^{13}$, zgodność postaw religijnych ułatwia wspólne rozwiązywanie problemów i uzgadnianie postępowania w różnych sprawach życia codziennego rodziny.

Dotychczas przeprowadzono wiele badań w obrębie różnych teorii religijności, określających jej związek z satysfakcją z małżeństwa, na którą wpływ ma niewątpliwie także komunikacja małżeńska ${ }^{14}$.

Badania Giblin ${ }^{15}$ wykazują znaczący wpływ religijności na komunikację, sposoby rozwiązywania konfliktów i podejmowania decyzji, zaangażowanie w relację, seksualność i rodzicielski wymiar małżeństwa. Co więcej, podobne postawy religijne małżonków ${ }^{16}$, czytanie Biblii i innych materiałów o tematyce religijnej, modlitwa i uczęszczanie do kościoła ${ }^{17}$, okazały się czynnikami wiążącymi się z niższym odsetkiem rozwodów ${ }^{18}$. Przyczyniały się one nawet do zmniejszania tendencji do rozważania czy rozmawiania o rozwodzie, co oznacza, że wzmacniały one gotowość pracy nad małżeństwem.

Również Walesa ${ }^{19}$ podkreślał znaczenie kompatybilności przekonań i praktyk religijnych małżonków dla zadowolenia z ich własnego małżeństwa. Uzyskane przez niego wyniki sugerują, że małżeństwa, których światopogląd religijny jest zintegrowany z życiem, są bardzo zadowolone z jakości swojej relacji. Natomiast niezgodność przekonań i praktyk religijnych może prowadzić nawet do poczucia psychicznej izolacji u jednego z małżonków.

\footnotetext{
${ }^{12}$ Por. M. Braun-Gałkowska, Psychospołeczne uwarunkowania powodzenia małżeństwa, „Roczniki Nauk Społecznych" $1976 \mathrm{nr}$ 4, s. 209-236.

${ }^{13}$ Por. C. Walesa, Rozwój zgodności religijnych przekonań i praktyk współmałżonków oraz jej związki z zadowoleniem z małżeństwa, „Roczniki filozoficzne” $1978 \mathrm{nr}$ 4, s. 91-113.

${ }^{14}$ Por. M.J. Anthony, The relationship between marital satisfaction and religious maturity, „Religious Education” $1993 \mathrm{nr}$ 88, s. 97-108; M.G. Dudley, F.A. Kosinski, Religiosity and marital satisfaction: A research note, „Review of Religious Research” $1990 \mathrm{nr} 32$, s. 78-86; T.B. Heaton, E.L. Pratt, The effects of religious homogamy on marital satisfaction and stability, „Journal of Family Issues” $1990 \mathrm{nr}$ 11, s. 191-207; C.L. Shehan, E.W. Bock, G.R. Lee, Religious heterogamy, religiosity and marital happiness: The case of Catholics, „Journal of Marriage and the Family" $1990 \mathrm{nr}$ 52, s. 73-79; M.R. Wilson, E.E. Filsinger, Religiosity and marital adjustment: Multidimensional interrelationship, ,Journal of Marriage and the Family” $1986 \mathrm{nr} 48$, s. 147-151.

${ }^{15}$ Por. P.R. Giblin, Marital spirituality: A quantitative study, ,Journal of Religion and Health” $1997 \mathrm{nr} 36$, s. 321-332.

${ }^{16}$ Zob. B. Beit-Hallami, M. Argyle, The psychology of religious behaviour: Belief and experience. London 1997.

${ }^{17}$ Por. A. Booth, D.R. Johnson, A. Branaman, A. Sica, Belief and behaviour: Does religion matter in today's marriage?, ,Journal of Marriage and the Family” $1995 \mathrm{nr}$ 57, s. 661-671.

${ }^{18}$ Por. V.R.A. Call, T.B. Heaton, Religious influence on marital stability, „Journal for the Scientific Study of Religion" $1997 \mathrm{nr} 36$, s. 382-392.

${ }^{19}$ Por. C. Walesa, art. cyt., s. 91-113.
} 
Tracewicz ${ }^{20}$, badając trwałość związku oraz nieodwołalność decyzji osób rozwiedzionych, założyła, że im bardziej centralną pozycję w systemie motywacyjnym jednostki zajmują wartości religijne, tym większe znaczenie ma stosunek osoby do religii w preferowanym przez nią modelu małżeństwa. Założenie to wynika ze zobowiązań, jakie Kościół nakłada na swoich wyznawców, a którym jest przyjmowanie i trwanie w określonym modelu małżeństwa, które kategorycznie zakazuje rozwodów. Omawiane wyniki pokazują, że większość osób zawierających ślub kościelny postrzega małżeństwo jako związek nierozerwalny. Dla $29 \%$ badanych motywacja religijna była najważniejsza, co dla Tracewicz ${ }^{21}$ było przejawem większego zobowiązania moralnego do dochowania wierności swojemu współmałżonkowi. Co więcej, dla większości (75\% badanych) dozgonność była na tyle ważnym elementem modelu małżeństwa, że nie dopuszczali oni nawet możliwości rozwodu.

Butler, Gardner i Bird ${ }^{22}$ modlitwę nazywają „zmiękczającą” aktywnością wśród religijnych par przeżywających konflikt. Oznacza to, że praktyki modlitewne małżonków pomagają rozwiązywać doświadczane przez nich problemy, wzmacniając tym samym ich relację oraz podejście zorientowane na partnera. Buduje to z kolei empatię, a także zmniejsza ryzyko przyjmowania stronniczej perspektywy wobec partnera, negatywne emocje i nadmiernie emocjonalne sposoby reagowania względem niego.

Brody wraz ze współpracownikami ${ }^{23}$ skupił się natomiast na formalnej religijności afro-amerykańskich małżonków. Jest ona definiowana jako częstotliwość uczęszczania do kościoła oraz osobista ważność uczestnictwa w nabożeństwach. Okazało się, że taka religijność była pozytywnie związana z wyższą jakością interakcji w małżeństwie (czego operacjonalizacją była doświadczana w relacji harmonia, zaangażowanie, ciepło i komunikacja).

Kolejne badania dotyczące powodzenia małżeństwa i ukazujące związki religijności z komunikacją to prace Braun-Gałkowskiej ${ }^{24}$, Khodabakhshiego ze współpracownika$\mathrm{mi}^{25}$ czy Rostowskiej i Żylińskiej ${ }^{26}$. Braun-Gałkowska ${ }^{27}$ dowiodła, że ludzie religijni

\footnotetext{
${ }^{20}$ Por. E. Tracewicz, Nieodwołalność decyzji zawarcia związku małżeńskiego w ocenie osób rozwiedzionych, „Zeszyty Naukowe KUL” 1981 nr 204, s. 81-104.

${ }^{21}$ Por. Tamże.

${ }^{22}$ Por. M.H. Butler, B.C. Gardner, M.H. Bird, Not just a time-out: Change dynamics of prayer for religious couples in conflict situations, „Family Process” $1998 \mathrm{nr} 37$, s. 451-478.

${ }^{23}$ Por. G.H. Brody, Z. Stoneman, D. Flor, C. McCrary, Religion's Role in Organizing Family Relationship: Family Process in Rural, Two - Parent African American Families, ,Journal of Marriage and The Family” $1994 \mathrm{nr} 56$, s. 878-888.

${ }^{24}$ Por. M. Braun-Gałkowska, Znaczenie religijności małżonków dla powodzenia ich związku, w: T. Kukołowicz (red.), Z badań nad rodziną, Lublin 1984, s. 57-67.

${ }^{25}$ Por. A. Khodabakhshi, F.H. Hossein-Abadi, Religiosity, Marital Satisfaction and Child Rearing, „Pastoral Psychology" 2009 nr 57, s. 211-221; A. Khodabakhshi, E. Azad-Marzabadi, S.M.N. Ashrafi, The Influence of Religiosity on Marital Satisfaction, ,Journal of Social Sciences” $2008 \mathrm{nr} 4$ (2), s. 128-135.

${ }^{26}$ Por. T. Rostowska, P. Żylińska, Stopień zaangażowania religijnego a poziom jakości małżeńskiej partnerów, w: T. Rostowska (red.), Psychologia rodziny. Małżeństwo i rodzina wobec współczesnych wyzwań, Warszawa 2009, s. 117-135.

${ }^{27}$ Por. M. Braun-Gałkowska, Znaczenie religijności małżonków..., art. cyt. s. 57-67.
} 

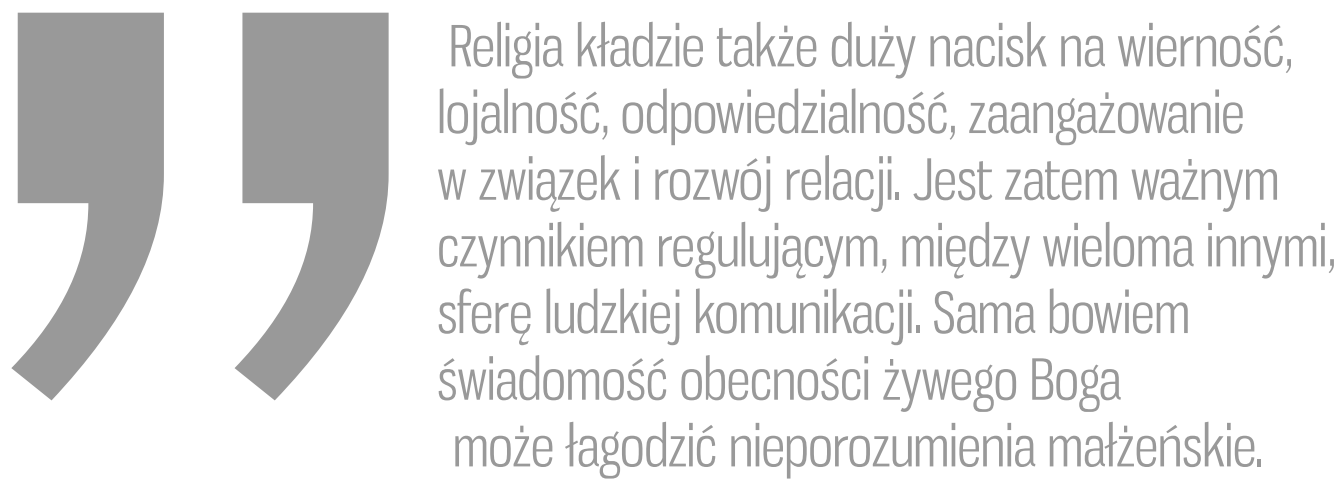

w większym stopniu przejawiają chęć i gotowość do współpracy, postawę altruistyczną oraz mają wyższe oczekiwania co do małżeństwa. Potwierdzają to także badania Śliwa$\mathrm{ka}^{28}$, z których wynika, że osoby religijne mają większą skłonność do zachowań altruistycznych. Z kolei, przyjmowanie takiej postawy w małżeństwie wydaje się być bardzo istotne, bowiem wiąże się z wrażliwością na potrzeby współmałżonka i gotowością do niesienia mu pomocy, do czego niewątpliwie wymagana jest prawidłowa i sprawna komunikacja. Rostowska i Żylińska ${ }^{29}$ z kolei, interesowały się związkiem między zaangażowaniem religijnym małżonków a poziomem jakości ich życia małżeńskiego. Uzyskane analizy dowodzą, iż osoby o typie religijności personalnej wyżej oceniały jakość swoich małżeństw, niż osoby o typie religijności apersonalnej.

Poza wyżej wymienionymi - wśród wielu innych - badaniami traktującymi o związku religijności z komunikacją małżeńską, istnieje również literatura przedmiotu, dowodząca tegoż związku. Cieślak ${ }^{30}$ zwraca bowiem uwagę na trzy metody rozumienia związku religijności z relacją małżeńską. Pierwszy dotyczy podobieństwa partnerów w zakresie przynależności religijnej oraz postaw i przekonań religijnych. Drugi ujmuje religijność jako pewnego rodzaju barierę zapobiegającą rozpadowi małżeństwa. Ostatni koncentruje się na religijności jako czynniku wspierającym budowanie pozytywnej perspektywy w małżeństwie. Autor twierdzi, że religijność dostarcza wsparcia społecznego dzięki umożliwianiu małżonkom nawiązywania i rozwijania kontaktów z innymi rodzinami, wyznającymi tę samą religię, a co za tym idzie, te same wartości. Innymi źródłami wsparcia są ponadto różnego rodzaju grupy i instytucje religijne. Religia, będąc źródłem systemu wartości, dostarcza także wzorów postępowania w różnych sytuacjach życiowych, promuje postawę miłości i przebaczenia, pomagając w ten sposób rozwiązywać codzienne trudności ${ }^{31}$. Religia kładzie także duży nacisk na wierność, lojalność, odpo-

\footnotetext{
${ }^{28}$ Por. J. Śliwak, Altruizm a religijność. Przegląd badań, w: Wykłady z psychologii w KUL, Lublin 1989, s. 187-198; J. Śliwak, Altruizm a religijność człowieka - badania empiryczne, „Roczniki Filozoficzne” $1993 \mathrm{nr}$ 4, s. 41-52.

${ }^{29}$ Por. T. Rostowska, P. Żylińska, art. cyt., s. 117-135.

${ }^{30}$ Por. K. Cieślak, Religijność a sukces małżeński, „Problemy Rodziny” 1991 nr 6 (180), s. 11-15.

${ }^{31}$ Por. R. Bartczuk, M. Jarosz, Funkcja Religijności w Procesie Radzenia Sobie ze Stresem Koncepcja
} 
wiedzialność, zaangażowanie w związek i rozwój relacji. Jest zatem ważnym czynnikiem regulującym, między wieloma innymi, sferę ludzkiej komunikacji. Sama bowiem świadomość obecności żywego Boga może łagodzić nieporozumienia małżeńskie. Cieślak ${ }^{32}$ dostrzega jednak również niekorzystny wpływ religijności na związek małżeński, będący konsekwencją nieprawidłowego typu religijności, jaki prezentują małżonkowie. Skutki religijności, odczuwane przez małżonków w ich relacji mogą być więc zarówno pozytywne, jak i negatywne.

\section{Metodologia badań \\ Uzasadnienie i przedmiot}

Analiza dotychczasowych badań i literatury przedmiotu sugeruje potrzebę weryfikacji związku między centralnością religijności a komunikacją małżeńską, nie tylko dlatego, że jest on kluczowym elementem powodzenia i satysfakcji małżeńskiej, ale również z powodu niewielkiego zainteresowania na gruncie polskim, nie tylko w różnorakich dziedzinach naukowych, ale również w aspekcie społecznym. Coraz częściej zagadnienie to jest wręcz niedoceniane, a nawet ignorowane przez społeczeństwo.

Temat wydaje się zasadny również ze względu na fakt, iż dotąd przeprowadzono niewiele badań nad związkiem podanych zmiennych, a te, które istnieją, pochodzą głównie z analizy populacji amerykańskiej i kanadyjskiej. Można natomiast przywołać sporo badań, które uwzględniają komunikację jako jeden z aspektów satysfakcji z małżeństwa lub zadowolenia z małżeństwa ${ }^{33}$. Inne odnoszą się do znaczenia religijności w małżeńskim zaangażowaniu, co stanowi jeden z aspektów ujętych przez Kaźmierczak i Plopę ${ }^{34}$. Jeszcze inne, z kolei, traktują o małżeńskich konfliktach werbalnych czy stylach komunikowania $\operatorname{się}^{35}$. Wszystkie przytoczone badania prezentują istotne znaczenie religijności w podtrzymywaniu małżeństwa, zaangażowaniu oraz adaptacyjnym sposobie rozwiązywania konfliktów. Fakt ten implikuje potrzebę weryfikacji komunikacji małżeńskiej, gdyż to ona, w znacznej mierze, decyduje o powodzeniu związku małżeńskiego.

Niniejszy projekt badawczy ujmuje religijność w jej aspekcie poznawczym, odnosząc się do roli, jaką pełni ona w systemie konstruktów osobistych, ze względu na jej moc regulacyjną w odniesieniu do różnych aspektów funkcjonowania człowieka ${ }^{36}$. Jedną ze

\footnotetext{
Kennetha I. Pargamenta, „Roczniki Psychologiczne” 2006 nr 9 (1), s. 37-52.

${ }^{32}$ Por. K. Cieślak, art. cyt., s. 11-15.

${ }^{33}$ Por. M. Braun-Gałkowska, Znaczenie religijności małżonków..., art. cyt. s. 57-67; O.S. Hünler, T. Gencoz, The effect of religiousness on marital satisfaction: testing the mediator role of marital problem solving between religiousness and marital satisfaction relationship, „Contemporary Family Therapy” $2005 \mathrm{nr} 27$ (1), s. 123-136; A. Khodabakhshi, F.H. Hossein-Abadi, art. cyt., s. 211-221.

${ }^{34}$ Zob. M. Kaźmierczak, M. Plopa, dz. cyt.

${ }^{35}$ Por. G.H. Brody, Z. Stoneman, D. Flor, C. McCrary, art. cyt., s. 878-888; A. Mahoney, K.I. Pargament, T. Jewell, A.B. Swank, E. Scott, E. Emery, M. Rye, Marriage and the spiritual realm-the role of proximal and distal religious constructs in marital functioning, ,Journal of Family Psychology” 1999 nr 13, s. 321-338.

${ }^{36}$ Por. B. Zarzycka, art. cyt., s. 231-261.
} 

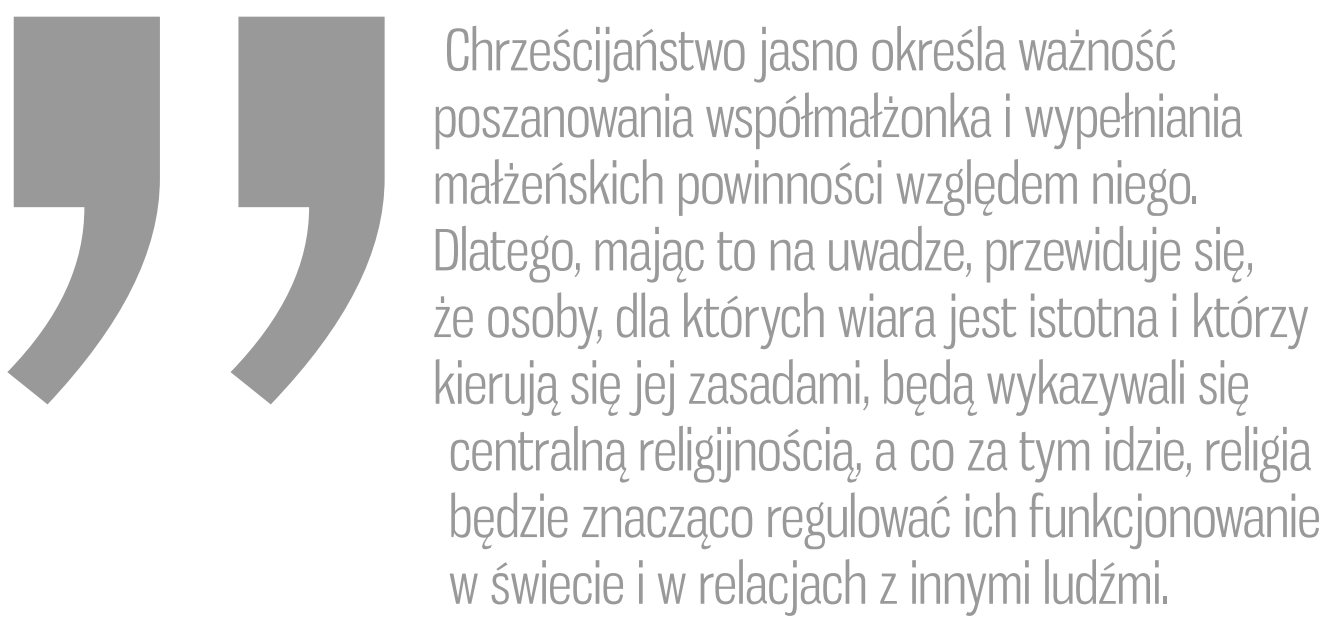

sfer ludzkiego życia jest komunikacja, której szczególnie ważnym rodzajem jest komunikacja małżeńska. Chrześcijaństwo jasno określa ważność poszanowania współmałżonka i wypełniania małżeńskich powinności względem niego. Dlatego, mając to na uwadze, przewiduje się, że osoby, dla których wiara jest istotna i którzy kierują się jej zasadami, będą wykazywali się centralną religijnością, a co za tym idzie, religia będzie znacząco regulować ich funkcjonowanie w świecie i w relacjach z innymi ludźmi. Zasadne może być zatem przeprowadzenie pogłębionej analizy niniejszego tematu.

\section{Problem i problematyka}

Religijność, zgodnie z wielofunkcyjnym modelem religijności, autorstwa Stefana Hubera, definiowana jest jako subiektywne ustosunkowanie się człowieka do norm i twierdzeń, które obowiązują w danej religii. Jest to struktura wkomponowana w życie psychiczne człowieka, które konstytuuje jego osobowość. Religia integruje ludzką osobowość i nadaje jej kierunek funkcjonowania ${ }^{37}$. Wśród wymiarów religijności, Huber wymienia zainteresowanie problematyką religijną, przekonania religijne, modlitwę, doświadczenie religijne oraz kult.

Drugą analizowaną zmienną jest komunikacja w małżeństwie, stanowiąca jeden z głównych czynników wpływających na powodzenie małżeństwa ${ }^{38}$. Komunikacja ta powinna charakteryzować się zasadami otwartego i pełnego porozumienia, zarówno w relacji werbalnej jak i niewerbalnej, co pozytywnie wpływa na budowanie związku oraz na przebieg kontaktu międzyosobowego. Prawidłowa komunikacja powinna składać się z jasnego komunikatu, gdzie wyrażanie myśli następuje w sposób zrozumiały dla od-

\footnotetext{
${ }^{37}$ Por. Z. Golan, Pojęcie religijności, w: S. Głaz (red.), Podstawowe zagadnienia psychologii religii, Kraków 2006, s. 71-79.

${ }^{38}$ Zob. M. Braun-Gałkowska, Miłość aktywna. Psychiczne uwarunkowania powodzenia małżeństwa, Warszawa 1985; M. Ryś, Psychologia małżeństwa. Zarys problematyki, Warszawa 1993; M. Ryś, Systemy rodzinne. Metody badań struktury rodziny pochodzenia i rodziny własnej, Warszawa 2008.
} 
biorcy, pozbawiony wieloznaczności oraz z otwartości, czyli przekazywania informacji w sposób bezpośredni ${ }^{39}$. Porozumiewanie się, czyli właśnie komunikacja, umożliwia wzajemne poznawanie się, rozwiązywanie konfliktów, a także ciągły rozwój relacji małżeńskiej ${ }^{40}$. Partnerzy zaangażowani w związek powinni troszczyć się wspólnie o okazywanie sobie szacunku poprzez docenianie własnych wysiłków, tworzenie atmosfery wzajemnego zrozumienia i bliskości w relacji oraz unikanie przejawiania agresji wobec siebie oraz chęci zdominowania i kontrolowania współmałżonka ${ }^{41}$.

Na podstawie powyższych analiz zasadne wydaje się zatem sformułowanie problemu badawczego w sposób następujący: Czy istnieją związki istotne statystycznie między centralnością religijności a komunikacją w małżeństwie?

Postawiono także następujące hipotezy badawcze:

- H1: Istnieją związki istotne statystycznie między centralnym usytuowaniem religijności w poznawczej strukturze osobowości i pozytywną komunikacją w małżeństwie.

- H2: Istnieją różnice istotne statystycznie w zakresie komunikacji małżeńskiej u osób o niższej i wyższej centralności religijności.

- H3: Istnieją związki istotne statystycznie między wymiarami religijności a wymiarami komunikacji małżeńskiej.

- H4: Częstotliwość uczestnictwa w nabożeństwach koreluje istotnie statystycznie z komunikacją w małżeństwie.

- H5: Wymiar centralności religijności zwany modlitwą koreluje istotnie statystycznie w stopniu wyższym, niż pozostałe wymiary centralności religijności z komunikacją w małżeństwie.

\section{Cel badań}

Celem teoretycznym niniejszych badań jest weryfikacja zależności między religijnością małżonków a jakością ich komunikacji interpersonalnej. Przewiduje się, że religia zajmująca bardziej centralną pozycję w systemie konstruktów osobistych człowieka, będzie wykazywała istotnie statystyczny związek z korzystnym stylem komunikowania się w małżeństwie. Oznacza to, że relacja takiego małżeństwa będzie charakteryzować się większym wsparciem i zaangażowaniem oraz mniejszą deprecjacją.

Wyniki mogą okazać się użyteczne w przypadku terapii małżeńskich i rodzinnych. Dlatego, celem aplikacyjnym jest poznanie poszczególnych wymiarów religijności i komunikacji małżeńskiej, by modyfikować je w pracy psychoterapeutycznej oraz by zapobiegać powstawaniu niewłaściwych wzorów komunikacji małżeńskiej, lub gdy to niemożliwe, redukować ich skutki.

\footnotetext{
${ }^{39}$ Por. L. Gapik, Psychologiczne problemy układów partnerskich, w: M. Kozakiewicz (red.), Wybrane zagadnienia poradnictwa małżeńskiego i rodzinnego, Warszawa 1985, s. 85-109.

${ }^{40}$ Zob. M. Braun-Gałkowska, Miłość aktywna..., dz. cyt.

${ }^{41}$ Zob. M. Kaźmierczak, M. Plopa, dz. cyt.
} 


\section{Charakterystyka zastosowanych metod}

Zmienną niezależną w prowadzonych badaniach jest religijność definiowana zgodnie z wielofunkcyjnym modelem religijności Stefana Hubera. Natomiast, zmienna zależna to komunikacja w małżeństwie.

Autorem Skali Centralności Religijności (C-15) jest Stefan Huber, tłumaczeniem niemieckiej wersji narzędzia w 2007 roku zajęła się Beata Zarzycka. W tym samym roku zostały przeprowadzone także badania adaptacyjne ${ }^{42}$. Podstawą teoretyczną Skali C-15 jest wielofunkcyjny model religijności Stefana Hubera, będący syntezą modeli Allporta ${ }^{43}$ oraz Glocka i Starka ${ }^{44}$, przy jednoczesnym korzystaniu z koncepcji konstruktów osobistych Kelley'ego ${ }^{45}$.

Metoda składa się z 15 pozycji, po 3 pozycje w każdej podskali:

1. Zainteresowanie problematyką religijną - mierzące ważność i częstość poznawczych konfrontacji z treściami religijnymi, bez uwzględnienia ich osobistej akceptacji. Wymiar ten dostarcza informacji o myśleniu na tematy religijne, intelektualnym zajmowaniu się treściami religijnymi i poszukiwaniu wiadomości o tematyce religijnej,

2. Przekonania religijne - badające stopień subiektywnie ocenianego prawdopodobieństwa istnienia rzeczywistości transcendentnej oraz intensywność postawy otwartości na rożne formy transcendencji,

3. Modlitwa - dostarczająca informacji na temat częstości nawiązywania kontaktu z rzeczywistością transcendentną oraz jego subiektywne znaczenie dla człowieka. Wskazuje na faktyczne aktualizowanie transcendentnych znaczeń,

4. Doświadczenie religijne - oznaczające częstość, z jaką transcendencja staje się elementem ludzkiego doświadczenia,

5. Kult - weryfikujące częstość i subiektywną ważność udziału człowieka w nabożeństwach religijnych. Informuje o społecznym zakorzenieniu religijnego systemu znaczeń ${ }^{46}$.

Skala pozwala na uzyskanie jednego wyniku ogólnego, który jest miarą centralności religijności oraz pięciu wyników w podskalach, które odnoszą się do motywacyjnych aspektów treściowych wymiarów religijności.

Rzetelność i trafność zewnętrzna Skali C-15 jest zadowalająca ${ }^{47}$.

Autorami Kwestionariusza Komunikacji Małżeńskiej (KKM) z 2008 roku są Maria Kaźmierczak oraz Mieczysław Plopa. Baza teoretyczna, na której opiera się Kwestionariusz, to teorie systemów, badające wzory interakcji pomiędzy członkami rodziny.

\footnotetext{
${ }^{42}$ Por. B. Zarzycka, art. cyt., s. 231-261.

${ }^{43}$ Zob. G. Allport, dz. cyt.

${ }^{44}$ Zob. Ch.Y. Glock, R. Stark, dz. cyt.; R. Stark, Ch.Y. Glock, dz. cyt.

${ }^{45}$ Zob. G. Kelly, dz. cyt.

${ }^{46}$ Por. B. Zarzycka, art. cyt., s. 231-261.

${ }^{47}$ Por. Tamże.
} 
Narzędzie zbudowane jest $\mathrm{z}$ dwóch równoległych wersji (dla kobiet i dla mężczyzn), różniących się jedynie formą czasowników. Kwestionariusz składa się z 30 stwierdzeń dotyczących samooceny komunikacji własnej oraz 30 twierdzeń dotyczących oceny komunikacji partnera. KKM pozwala na uzyskanie oddzielnych wyników na trzech wymiarach:

1. Wsparcie - oznaczające okazywanie szacunku partnerowi poprzez docenianie jego wysiłków, przejawianie zainteresowania problemami czy potrzebami partnera, a także aktywne uczestnictwo w procesie wspólnego rozwiązywania owych problemów - troska o partnera jest zatem przejawiana nie tylko w momentach trudnych, ale także w różnych sytuacjach dnia codziennego,

2. Zaangażowanie - mierzące umiejętność tworzenia atmosfery wzajemnego zrozumienia i bliskości w związku poprzez okazywanie sobie uczuć, podkreślanie wyjątkowości i ważności partnera dla nas, urozmaicanie rutyny dnia codziennego oraz zapobieganie konfliktom w związku,

3. Deprecjacja - wskazujące na przejawianie agresji wobec partnera, chęć zdominowania go na wielu płaszczyznach i kontrolowania jego różnych działań oraz brak poszanowania jego godności osobistej ${ }^{48}$.

Badani udzielają odpowiedzi na skali od 1 do 5, gdzie 1 oznacza, że nigdy się tak nie zachowują, a 5 - że zachowują się tak zawsze. Wyniki surowe przelicza się na steny, osobno opracowane dla kobiet i mężczyzn.

Zastosowanie KKM to badania indywidualne małżonków, ale również badania małżeństw celem poznania jakości komunikacji w ich małżeństwie.

Rzetelność i trafność dla poszczególnych wymiarów jest wysoka ${ }^{49}$.

\section{Sposób przeprowadzania badania}

Nieodpłatne badanie przeprowadzono metodą kuli śnieżnej. Badani, w niezaklejonej kopercie, otrzymywali baterię testów, w skład której wchodziła instrukcja, arkusz biograficzny, Skala C-15 oraz KKM (w wersji dopasowanej do płci respondenta: dla żony lub dla męża). Stosunek respondentów do udziału w badaniach był pozytywny - odpowiedzi udzielali oni chętnie i w sposób wyczerpujący. Wypełnianie baterii testów odbywało się w warunkach standardowych: pomieszczenie ciche, intymne, bez dystraktorów czy ograniczenia czasowego. Przeciętny czas udzielania odpowiedzi wynosił około 35 minut. W wyniku badania zebrano dane ilościowe, które opracowano następnie metodami statystycznymi, takimi jak statystyki opisowe, statystyczne testy różnic oraz analiza korelacji.

\section{Charakterystyka badanej grupy}

Grupę badanych stanowiło 100 osób (50 kobiet i 50 mężczyzn) w związku małżeńskim. Średni wiek badanych wynosił około 39 lat. Najmłodszy respondent miał 23 lata, najstar-

\footnotetext{
${ }^{48}$ Zob. M. Kaźmierczak, M. Plopa, dz. cyt.

${ }^{49}$ Zob. Tamże.
} 


\section{DIALOG RELIGII I KULTURY}

szy - 60 lat ( $M=39,44 ; S D=9,362)$. Średni wiek kobiet to 39 lat, przy odchyleniu standardowym wynoszącym 9,32. Najmłodsza kobieta była w wieku 24 lat, najstarsza - 60 lat. Średni wiek mężczyzn to również około 39 lat, przy odchyleniu standardowym równym 9,5. Najmłodszy mężczyzna miał 23 lata, najstarszy - 60 lat.

Średni czas trwania małżeństwa w grupie badanych wynosił ponad 14 lat. Małżeństwo z najkrótszym stażem małżeńskim liczyło sobie 1 rok, zaś najdłuższy - 38 lat $(M=14,37 ; S D=9,630)$.

Wykształcenie badanych nie jest mocno zróżnicowane, co prezentuje tabela 1 . Wykształcenie średnie posiada 45 osób, niepełne wyższe - 17, a wyższe - 38 .

Tabela 1 zawiera także dane dotyczące zamieszkania badanych. Na wsi mieszka 44 respondentów, w mieście od 50000 do 100000 mieszkańców - 20 badanych, a 36 w mieście powyżej 100000 mieszkańców.

Tabela 1. Wykształcenie i miejsce zamieszkania badanych ( $\mathrm{N}=100)$

\begin{tabular}{|l|l|l|l|l|l|l|}
\hline & \multicolumn{2}{|l|}{ Wykształcenie } & $\begin{array}{l}\text { Miej- } \\
\text { sce za- } \\
\text { miesz- } \\
\text { kania }\end{array}$ & \multicolumn{2}{l|}{} \\
\hline & Srednie & $\begin{array}{l}\text { Niepelne } \\
\text { wyższe }\end{array}$ & Wyższe & Wieś & Miasto 50-100 tys. & Miasto powyżej 100 tys. \\
\hline $\begin{array}{l}\text { Liczeb- } \\
\text { ność }\end{array}$ & 45 & 17 & 38 & 44 & 20 & 36 \\
\hline Procent & 45 & 17 & 38 & 44 & 20 & 36 \\
\hline
\end{tabular}

Prawie wszyscy badani, bo aż 98\%, to katolicy. Po jednej osobie to wyznawcy protestantyzmu i prawosławia. Nikt nie podał innego wyznania, niż wyżej wymienione (co przedstawia tabela 2).

Tabela 2. Wyznanie osób badanych (N=100)

\begin{tabular}{|l|l|l|}
\hline Wyznanie & Liczebność & Procent \\
\hline Katolicyzm & 98 & 98 \\
\hline Protestantyzm & 1 & 1 \\
\hline Prawosławie & 1 & 1 \\
\hline
\end{tabular}

\section{Analiza i interpretacja wyników}

W celu opracowania wyników zastosowano analizy statystyczne polegające na opisie statystycznym badanych zmiennych, analizie nasilenia różnic między wyodrębnionymi grupami oraz analizie korelacji między rozpatrywanymi zmiennymi. 


\section{Analiza nasilenia różnic między grupami o wyższej i niższej centralności religijności}

W celu weryfikacji hipotezy H1 (Istnieją związki istotne statystycznie między centralnym usytuowaniem religijności w poznawczej strukturze osobowości i pozytywną komunikacją w małżeństwie) oraz H2 (Istnieją różnice istotne statystycznie w zakresie komunikacji małżeńskiej u osób o niższej i wyższej centralności religijności) zastosowano test $t$, co przedstawia tabela 3 .

Tabela 3. Różnice między grupami o niskiej i wysokiej centralności religijności

\begin{tabular}{|l|l|l|l|l|l|l|}
\hline \multirow{2}{*}{ Zmienna } & $\begin{array}{l}\text { Centralność } \\
\text { religijności }\end{array}$ & $\boldsymbol{M}$ & $\boldsymbol{S D}$ & $\boldsymbol{t}$ & $\boldsymbol{d f}$ & $\boldsymbol{p}$ \\
\hline \multirow{2}{*}{ Wsparcie } & niska & 39.96 & 7.367 & -2.983 & 52 & $0.004^{*}$ \\
\cline { 2 - 8 } & wysoka & 44.81 & 4.14 & -2.983 & 40.946 & $0.005^{*}$ \\
\hline Zaangażowanie & niska & 31.59 & 6.1 & -2.071 & 52 & $0.043^{*}$ \\
\cline { 2 - 8 } & wysoka & 34.59 & 4.41 & -2.071 & 47.38 & $0.044^{*}$ \\
\hline Deprecjacja & niska & 23.4 & 7.23 & 1.498 & 52 & 0.14 \\
\cline { 2 - 8 } & wysoka & 20.67 & 6.18 & 1.498 & 50.766 & 0.14 \\
\hline
\end{tabular}

$M$-średnia; $S D$ - odchylenie standardowe

Poziom centralności religijności w sposób istotny statystycznie różnicuje grupy w zakresie wsparcia i zaangażowania. Oznacza to, że badani o wyższej centralności religijności $(M=44,81 ; S D=4,14)$ przejawiają tendencję do okazywania swojemu partnerowi większego wsparcia, niż osoby z niską centralnością religijności $(M=39,96 ; S D=7,367)$ : $\mathrm{t}(1,41)=-2,983 ; p<0,01$. Małżonkowie ci przejawiają więcej i częściej zachowania ukierunkowane na okazywanie partnerowi troski, zainteresowania i szacunku. Podobnie, w przypadku zaangażowania: $\mathrm{t}(1,52)=-2,071 ; p<0,05$; badani z wyższą centralnością religijności ( $M=34,59 ; S D=4,41)$ przejawiają większe zaangażowanie we własne małżeństwo, niż osoby z niską centralnością religijności $(M=31,59 ; S D=6,1)$, co przejawia się aktywnym budowaniem atmosfery bliskości i zaufania oraz podejmowaniem działań mających na celu zapobieganie konfliktom, lub, gdy już się one pojawią - angażowanie się wich rozwiązanie.

\section{Korelacje między zmiennymi}

Celem weryfikacji hipotezy H3 (Istnieją związki istotne statystycznie między wymiarami religijności a wymiarami komunikacji małżeńskiej), H4 (Częstotliwość uczestnictwa w nabożeństwach koreluje istotnie statystycznie z komunikacją w małżeństwie) i H5 (Wymiar centralności religijności zwany modlitwą koreluje istotnie statystycznie w stop- 
niu wyższym, niż pozostałe wymiary centralności religijności z komunikacją w małżeństwie) przeprowadzono korelacje w oparciu o testy nieparametryczne, ze względu na odbiegający od normalnego, rozkład zmiennych. Wyniki przy wykorzystaniu nieparametrycznego współczynnika rho Spearmana przedstawia tabela 4.

Tabela 4. Korelacje między wymiarami religijności a wymiarami komunikacji w oparciu o całą grupę badanych $(\mathrm{N}=100)$

\begin{tabular}{|l|l|l|l|l|l|l|}
\hline \multirow{2}{*}{ Zmienna } & \multicolumn{2}{l}{ Wsparcie } & \multicolumn{2}{l|}{ Zaangażowanie } & \multicolumn{2}{l|}{$\begin{array}{l}\text { Depre- } \\
\text { cjacja }\end{array}$} \\
\cline { 2 - 8 } & $\boldsymbol{r}$ & $\boldsymbol{p}$ & $\boldsymbol{r}$ & $\boldsymbol{p}$ & $\boldsymbol{r}$ & $\boldsymbol{p}$ \\
\hline Centralność religijności - wynik ogólny & $0.290^{* *}$ & 0.003 & $0.200^{*}$ & 0.046 & -0.194 & 0.053 \\
\hline Zainteresowanie problematyką religijną & $0.299^{* *}$ & 0.003 & $0.244^{*}$ & 0.014 & -0.162 & 0.108 \\
\hline Przekonania religijne & $0.198^{*}$ & 0.049 & 0.143 & 0.156 & -0.144 & 0.152 \\
\hline Modlitwa & $0.270^{* *}$ & 0.007 & 0.131 & 0.192 & $-0.237^{*}$ & 0.018 \\
\hline Doświadczenie religijne & $0.221^{*}$ & 0.027 & $0.209^{*}$ & 0.037 & -0.076 & 0.45 \\
\hline Kult & $0.213^{*}$ & 0.033 & 0.133 & 0.187 & -0.194 & 0.053 \\
\hline
\end{tabular}

Centralność religijności i wszystkie jej wymiary korelują w sposób istotny statystycznie z wymiarem wsparcia w komunikacji małżeńskiej. Każda z tych korelacji jest dodatnia i słaba. Oznacza to, że wraz ze wzrostem centralności religijności oraz poszczególnych jej wymiarów rośnie dawane partnerowi wsparcie. Im częściej więc osoba interesuje się zagadnieniami związanymi z religią $(r=0,299 ; p=0,003)$, im bardziej jest przekonana o istnieniu rzeczywistości transcendentnej $(r=0,198 ; p=0,049)$, im częściej modli się $(r=0,27 ; p=0,007)$ i uczestniczy w nabożeństwach o charakterze religijnym $(r=0,213$; $p=0,033)$ oraz czyni transcendencję elementem swoich doświadczeń $(r=0,221 ; p=0,027)$, tym częściej okazuje swojemu partnerowi szacunek, docenia jego starania i angażuje się w rozwiązywanie sytuacji konfliktowych.

Wymiary religijności wykazujące związki z wymiarem komunikacji małżeńskiej, jakim jest zaangażowanie, to: wynik ogólny centralności religijności $(r=0,2 ; p=0,046)$, zainteresowanie problematyką religijną $(r=0,244 ; p=0,014)$ oraz doświadczenie religijne $(r=0,209 ; p=0,037)$. Również w tym wymiarze małżeńskiej komunikacji korelacje są dodatnie i słabe. Oznacza to, że osoby z centralną pozycją religijności w poznawczej strukturze osobowości, które interesują się problematyką religijną i poznawczo konfrontują się z nią, dla których transcendencja jest częstym elementem ich doświadczeń, przejawiają większą skłonność do angażowania się w zachowania na rzecz relacji małżeńskiej. Do zachowań tego typu zaliczane jest budowanie atmosfery bliskości i zaufania, podkreślanie wyjątkowości i ważności partnera, podejmowanie działań, które mogą urozma- 
icić codzienną rutynę oraz zapobiec potencjalnym konfliktom, a gdy się już pojawią, szybkie ich rozwiązywanie.

Jeśli zaś chodzi o wymiar religijności korelujący z deprecjacją jako wymiarem komunikacji małżeńskiej, wyniki wskazują wyłącznie na modlitwę $(r=-0,237 ; p=0,018)$. Jest to korelacja ujemna i słaba, co oznacza, że im częściej badani uczestniczą w nabożeństwach i modlą się, tym rzadziej przejawiają oni tendencję do agresywnych zachowań wobec swojego partnera. Silne tendencje zostały ponadto zaobserwowane w przypadku wyniku ogólnego centralności religijności $(r=-0,194 ; p=0,053)$ i kultu $(r=-0,194 ; p=0,053)$. Oznacza to, że im częściej badani nawiązują kontakt z rzeczywistością transcendentną i nadają temu kontaktowi subiektywną ważność oraz gdy religia ogólnie zajmuje bardziej centralną pozycję w poznawczej strukturze ich osobowości, tym rzadziej przejawiają oni skłonność do agresji wobec współmałżonka.

Analizom poddano także korelacje po wyodrębnieniu grup badanych ze względu na ich płeć, co przedstawiają tabele 5 i 6 .

Tabela 5. Korelacje między wymiarami religijności a wymiarami komunikacji w oparciu o grupę kobiet $(\mathrm{N}=50)$

\begin{tabular}{|l|l|l|l|l|l|l|}
\hline \multirow{2}{*}{ Zmienna } & \multicolumn{2}{l}{ Wsparcie } & \multicolumn{2}{l|}{ Zaangażowanie } & $\begin{array}{l}\text { Depre- } \\
\text { cjacja }\end{array}$ & \\
\cline { 2 - 8 } & $\boldsymbol{r}$ & $\boldsymbol{p}$ & $\boldsymbol{r}$ & $\boldsymbol{p}$ & $\boldsymbol{r}$ & $\boldsymbol{p}$ \\
\hline Centralność religijności - wynik ogólny & $0.373^{* *}$ & 0.008 & 0.259 & 0.069 & -0.247 & 0.084 \\
\hline Zainteresowanie problematyką religijną & $0.389^{* *}$ & 0.005 & $0.282^{*}$ & 0.048 & -0.2 & 0.163 \\
\hline Przekonania religijne & 0.172 & 0.233 & 0.07 & 0.63 & -0.093 & 0.522 \\
\hline Modlitwa & $0.296^{*}$ & 0.037 & 0.197 & 0.17 & $-0.287^{*}$ & 0.043 \\
\hline Doświadczenie religijne & 0.275 & 0.054 & 0.225 & 0.116 & -0.077 & 0.595 \\
\hline Kult & $0.341^{*}$ & 0.015 & 0.238 & 0.096 & $-0.322^{*}$ & 0.023 \\
\hline
\end{tabular}

Wymiary religijności kobiet, wykazujące dodatnie, umiarkowane korelacje istotne statystycznie z wymiarem komunikacji małżeńskiej, jakim jest wsparcie, to: wynik ogólny centralności religijności $(r=0,373 ; p=0,008)$, zainteresowanie problematyką religijną $(r=0,389 ; p=0,005)$, oraz kult $(r=0,341 ; p=0,015)$. Na poziomie dodatniej słabej korelacji istotnej statystycznie plasuje się ponadto związek modlitwy z wsparciem $(r=0,296$; $p=0,037$ ). Oznacza to, że kobiety, u których religijność zajmuje pozycję centralną w poznawczej strukturze osobowości, które często myślą na tematy religijne i poszukują informacji z nimi związanych, szukające osobistego kontaktu z rzeczywistością transcendentną i często biorące udział w różnego rodzaju nabożeństwach, okazują swojemu partnerowi większy szacunek, częściej doceniają jego starania i silniej angażują się w rozwiązywanie sytuacji trudnych. 


\section{DIALOG RELIGII I KULTURY}

Wymiarem religijności, związanym z zaangażowaniem w komunikacji małżeńskiej w sposób istotny statystycznie, na poziomie słabym, w korelacji dodatniej, jest zainteresowanie problematyką religijną ( $r=0,282 ; p=0,048)$. Wynik ten sugeruje, że kobiety, które częściej konfrontują się poznawczo z zagadnieniami o charakterze religijnym, przejawiają większą tendencję do angażowania się w zachowania mające na celu budowanie atmosfery bliskości i zaufania oraz podkreślania wyjątkowości i ważności swojego partnera. Kobiety te również częściej podejmują działania, które mają urozmaicać codzienną rutynę oraz zapobiegać potencjalnym konfliktom.

Ujemne korelacje istotne statystycznie wykryto natomiast między modlitwą a deprecjacją $(r=-0,287 ; p=0,043)$ - gdzie korelacja jest raczej słaba oraz między kultem a deprecjacją $(r=-0,322 ; p=0,023)$ - korelacja jest umiarkowana. Oznacza to, że im częściej kobiety nawiązują kontakt z rzeczywistością transcendentną oraz biorą udział w nabożeństwach, tym mniejszą skłonnością do zachowań agresywnych wobec swojego partnera się charakteryzują. Podejmują one także mniej prób kontrolowania go czy dominowania nad nim w różnych sferach życia.

Tabela 6. Korelacje między wymiarami religijności a wymiarami komunikacji w oparciu o grupę mężczyzn $(\mathbf{N}=50)$

\begin{tabular}{|l|l|l|l|l|l|l|}
\hline \multirow{2}{*}{ Zmienna } & \multicolumn{2}{l}{ Wsparcie } & \multicolumn{2}{l|}{ Zaangażowanie } & \multicolumn{2}{l|}{$\begin{array}{l}\text { Deprecja- } \\
\text { cja }\end{array}$} \\
\cline { 2 - 8 } & $\boldsymbol{r}$ & $\boldsymbol{p}$ & $\boldsymbol{r}$ & $\boldsymbol{p}$ & $\boldsymbol{r}$ & $\boldsymbol{p}$ \\
\hline Centralność religijności - wynik ogólny & 0.176 & 0.223 & 0.138 & 0.339 & -0.181 & 0.207 \\
\hline Zainteresowanie problematyką religijną & 0.181 & 0.209 & 0.189 & 0.188 & -0.146 & 0.313 \\
\hline Przekonania religijne & 0.204 & 0.156 & 0.209 & 0.145 & -0.209 & 0.145 \\
\hline Modlitwa & 0.218 & 0.129 & 0.086 & 0.552 & -0.225 & 0.116 \\
\hline Doświadczenie religijne & 0.155 & 0.281 & 0.189 & 0.189 & -0.085 & 0.556 \\
\hline Kult & 0.069 & 0.636 & 0.039 & 0.786 & -0.093 & 0.520 \\
\hline
\end{tabular}

W grupie mężczyzn nie zaobserwowano żadnych korelacji ani tendencji na poziomie istotnym statystycznie.

\section{Dyskusja dotycząca wyników}

Przeprowadzone analizy uzyskanych wyników pozwoliły na częściowe potwierdzenie postawionych hipotez. Weryfikując je wykryto, że osoby o wyższej i niższej centralności religijności różnią się między sobą na poziomie istotnym statystycznie w zakresie posiadanych wzorców komunikowania się, co potwierdza hipotezę H2 (Istnieją różnice istotne statystycznie w zakresie komunikacji małżeńskiej u osób o niższej i wyższej centralności religijności). Wykazano bowiem, że osoby o wysokiej centralności religijności przejawiają większe wsparcie i zaangażowanie wobec współmałżonka, niż osoby z niską centralnością religijności (tabela 
3). Dane te są kompatybilne $\mathrm{z}$ analizami Khodabakhshiego i jego współpracowników ${ }^{50}$, w których dowiedziono, że osoby o niższej religijności deklarują niższą satysfakcję z małżeństwa, niż osoby o wyższej religijności. W badaniach tych ogólne poczucie satysfakcji z małżeństwa operacjonalizowane było między innymi poprzez komunikację małżeńską. Uzyskane wyniki można odnieść także do badań Mahoney i współpracowników ${ }^{51}$, w których odkryto, że osoby, postrzegające swoje małżeństwo jako związek uświęcony, charakteryzowały się większą chęcią i gotowością do współpracy przy rozwiązywaniu konfliktów. W prowadzonych badaniach udowodniono także, że osoby z wyższą centralnością religijności dawały większe wsparcie i zaangażowanie małżonkowi. Wymiary te, zgodnie z koncepcją Kaźmierczak i Plopy ${ }^{52}$ ujmują m.in. aktywne zaangażowanie małżonków we wspólne rozwiązywanie problemów oraz dążenie do kompromisów w czasie kłótni. Uzyskane wyniki wpisują się więc w rezultaty uzyskane we wspomnianych wyżej badaniach. Podobnie, można je odnieść do pracy Braun-Gałkowskiej ${ }^{53}$, gdzie udowodniono, że ludzie religijni wykazują większą chęć i gotowość do współpracy, a więc również do rozwiązywania pojawiających się trudności. Kolejnymi badaniami, które wspierają uzyskane wyniki są badania Rostowskiej i Żylińskiej ${ }^{54}$. Autorki wykazały, że osoby charakteryzujące się personalnym typem religijności, wyżej oceniały jakość swoich małżeństw, niż osoby o typie religijności apersonalnej. Ta pierwsza - religijność personalna - cechuje się autentycznym zaangażowaniem jednostki w relację z Bogiem, gdzie religia integruje uznawany przez nią świat wartości, tym samym, realnie wpływając na jej funkcjonowanie ${ }^{55}$. W dalszej konsekwencji oznacza to, że religia i wartości religijne przyjmują charakter autonomiczny, stanowiąc centralną strukturę w poznawczej strukturze osobowości, mogąc regulować zachowanie człowieka ${ }^{56}$. Osoby, które odznaczały się takim typem religijności, wyżej oceniały jakość swoich małżeństw, na co niewątpliwy wpływ miała również jakość komunikacji, zaliczanej przez Braun-Gałkowską ${ }^{57}$ do czynników mających duże znaczenie dla powodzenia małżeństwa. Uzyskane wyniki pokazują również, iż osoby o wyższej centralności religijności przejawiają korzystniejsze wzorce komunikowania się. Oznacza to, że dają oni współmałżonkowi większe wsparcie i bardziej angażują się w związek, niż osoby o niższej centralności religijności, a tym samym poprawiają postrzeganąjakość małżeństwa.

Fakt, że hipoteza H2 (Istnieją różnice istotne statystycznie w zakresie komunikacji małżeńskiej u osób o niższej $i$ wyższej centralności religijności) potwierdziła się częściowo (bo w zakresie wsparcia i zaangażowania) może wynikać z tego, że wzorce porozu-

\footnotetext{
${ }^{50}$ Por. A. Khodabakhshi, F.H. Hossein-Abadi, art. cyt., s. 211-221; A. Khodabakhshi, E. Azad-Marzabadi, S.M.N. Ashrafi, art. cyt., s. 128-135.

${ }^{51}$ Por. A. Mahoney, K.I. Pargament, T. Jewell, A.B. Swank, E. Scott, E. Emery, M. Rye, art. cyt., s. 321-338.

${ }^{52}$ Zob. M. Kaźmierczak, M. Plopa, dz. cyt.

${ }^{53}$ Por. M. Braun-Gałkowska, Znaczenie religijjności małżonków..., art. cyt. s. 57-67.

${ }^{54}$ Por. T. Rostowska, P. Żylińska, art. cyt., s. 117-135.

${ }^{55}$ Zob. R. Jaworski, Psychologiczne korelaty religijności personalnej, Lublin 1989.

${ }^{56}$ Por. B. Zarzycka, art. cyt., s. 231-261.

${ }^{57}$ Zob. M. Braun-Gałkowska, Miłość aktywna..., dz. cyt.
} 


\section{DIALOG RELIGII I KULTURY}

miewania się kształtują również inne czynniki, niż wyznawana religia. Ogromne znaczenie w jakości komunikacji małżeńskiej mają m.in. cechy osobowości (ekstrawersja, sumienność, neurotyzm i ugodowość), co potwierdzają badania Michałek ${ }^{58}$. Weryfikowane w nich były związki między profilami osobowościowymi małżonków (mierzonymi w oparciu o model pięcioczynnikowy), a jakością ich małżeństwa. Badania te wykryły, że wymiar komunikacji małżeńskiej, jakim jest wsparcie, koreluje z ekstrawersją oraz ugodowością; zaangażowanie współwystępuje z ekstrawersją, ugodowością i sumiennością, z kolei deprecjacja - z neurotyzmem i ugodowością ${ }^{59}$. Inne badania ${ }^{60}$ ukazały związek między retrospektywną oceną postaw rodzicielskich, a wzorcem komunikowania się z małżonkiem. Mężowie, oceniający swoich rodziców jako godnych zaufania i otwartych na problemy dziecka, charakteryzowali się większą skłonnością do wspierania swoich żon i zaangażowania się $w$ relację. $Z$ kolei żony, negatywnie oceniające postawy własnych matek, przejawiały wyższy poziom deprecjacji w małżeństwie. Istotnym czynnikiem, odkrytym w badaniach, był prezentowany styl przywiązania partnerów. Stwierdzono bowiem, iż osoby z bezpiecznym stylem przywiązania cechują się zachowaniami, mającymi pozytywny wpływ na jakość komunikacji w związku ${ }^{61}$.

Podsumowując dane dotyczące hipotezy H2 (Istnieją różnice istotne statystycznie w zakresie komunikacji małżeńskiej u osób o niższej i wyższej centralności religijności), należy podkreślić, iż istnieje wiele różnych czynników, mogących oddziaływać na komunikację małżeńską. Oznacza to, że religijność nie zawsze jest jednym z nich i nie zawsze jej znaczenie jest najbardziej istotne. Wniosek ten potwierdzają także prace Braun-Gałkowskiej $^{62}$, dotyczące postaw religijnych i powodzenia w małżeństwie (gdzie jednym z ujmowanych aspektów była komunikacja). Wykazano bowiem, że nie ma związku pomiędzy rozpatrywanymi w nich zmiennymi.

Częściowo potwierdzona została także hipoteza H1: Istnieją związki istotne statystycznie między centralnym usytuowaniem religijności w poznawczej strukturze osobowości i pozytywną komunikacją w małżeństwie, zwłaszcza, jeśli chodzi wymiar komunikacji jakim jest wsparcie i zaangażowanie (tabela 4). Wymiar wsparcia przez Kaźmierczak i Plope ${ }^{63}$ charakteryzowany jest jako chęć i gotowość do aktywnego uczestnictwa w procesie rozwiązywania problemów współmałżonka, zainteresowanie jego potrzebami, docenianie jego wysiłków i pracy oraz okazywanie mu szacunku. Z kolei zaangażowanie definiowane jest jako dbałość o budowanie atmosfery bliskości i zaufania, podkreślanie ważności współmałżonka, adorowanie go, podejmowanie działań urozmaicających codzienną rutynę i zapobie-

\footnotetext{
${ }^{58}$ Zob. J. Michałek, Rola cech osobowości partnerów w kształtowaniu jakości związku małżeńskiego, niepublikowana praca magisterska napisana pod kierunkiem M. Kaźmierczak, Gdańsk 2008, cyt. za: M. Kaźmierczak, M. Plopa, dz. cyt.

${ }^{59}$ Zob. Tamże.

${ }^{60}$ Zob. M. Kaźmierczak, M. Plopa, dz. cyt.

${ }^{61}$ Zob. Tamże.

${ }^{62}$ Por. M. Braun-Gałkowska, Psychospołeczne uwarunkowania..., art. cyt., s. 209-236; M. Braun-Gałkowska, Miłość aktywna..., dz. cyt.

${ }^{63}$ Zob. M. Kaźmierczak, M. Plopa, dz. cyt.
} 
gających potencjalnym konfliktom małżeńskim. Deprecjacja nie koreluje natomiast z wynikiem ogólnym centralności religijności. Oznacza to, że wraz ze wzrostem centralności religijności oraz poszczególnych jej wymiarów rośnie dawane partnerowi wsparcie. Im częściej osoba interesuje się zagadnieniami związanymi z religią, im bardziej jest przekonana o istnieniu rzeczywistości transcendentnej, im częściej modli się i uczestniczy w nabożeństwach o charakterze religijnym oraz czyni transcendencję elementem swoich doświadczeń, tym częściej okazuje swojemu partnerowi szacunek, docenia jego starania i angażuje się w rozwiązywanie sytuacji konfliktowych. Ponadto, osoby z centralną pozycją religijności w poznawczej strukturze osobowości, które interesują się problematyką religijną i poznawczo konfrontują się z nimi, dla których transcendencja jest częstym elementem ich doświadczeń, przejawiają większą skłonność do angażowania się w zachowania na rzecz relacji małżeńskiej. Działania podejmowane przez te osoby opisano wyżej. Wyniki te korespondują z tendencjami wykazanymi przez Bootha i jego współpracowników ${ }^{64}$, którzy dowiedli, że czytanie materiałów religijnych, a w konsekwencji refleksja nad treściami religijnymi i uczęszczanie do kościoła, wzmacniały chęć i gotowość do pracy nad małżeństwem. Praca ta może między innymi opierać się na poprawie komunikacji, do której zalicza się właśnie okazywane partnerowi wsparcie i zaangażowanie w relację.

Również częściowo potwierdzona została hipoteza H3 (Istnieją związki istotne statystycznie między wymiarami religijności a wymiarami komunikacji małżeńskiej). Związki wykryto bowiem między wsparciem i wszystkimi wskaźnikami centralności religijności, to jest z ogólnym wynikiem centralności religijności, zainteresowaniem problematyką religijną, modlitwą, doświadczeniem religijnym, kultem i przekonaniami religijnymi. Korelacje zauważono także między zaangażowaniem a ogólnym wynikiem centralności religijności, zainteresowaniem problematyką religijną i doświadczeniem religijnym. Ostatni z wymiarów komunikacji małżeńskiej - deprecjacja - koreluje ujemnie jedynie z modlitwą. Wyniki te należy interpretować następująco: im częściej osoba interesuje się zagadnieniami związanymi z religią, jest bardziej przekonana o istnieniu rzeczywistości transcendentnej, częściej się modli i uczestniczy w nabożeństwach oraz czyni transcendencję elementem swoich doświadczeń, tym częściej okazuje swojemu partnerowi szacunek, docenia jego starania i angażuje się w rozwiązywanie sytuacji problemowych. Ponadto, osoby z centralną pozycją religijności w poznawczej strukturze osobowości, które interesują się problematyką religijną i poznawczo konfrontują się z nią, dla których transcendencja jest częstym elementem ich doświadczeń, przejawiają większą skłonność do angażowania się w zachowania na rzecz małżeństwa, które scharakteryzowano wyżej. Co więcej, im częściej badani uczestniczą w nabożeństwach i modlą się, tym rzadziej przejawiają oni tendencje do agresywnych zachowań wobec swojego partnera, rzadziej próbują go zdominować, przejąć nad nim kontrolę czy nie szanują jego godności. Uzyskane wyniki poprzeć można analizą Walesy ${ }^{65}$, gdzie wykazano, iż małżeństwa, których światopogląd religijny był prawdziwie zintegrowany z ich życiem, wysoko oceniały jakość swoich relacji, nie od

\footnotetext{
${ }^{64}$ Por. A. Booth, D.R. Johnson, A. Branaman, A. Sica, art. cyt., s. 661-671.

${ }^{65}$ Por. C. Walesa, art. cyt., s. 91-113.
} 


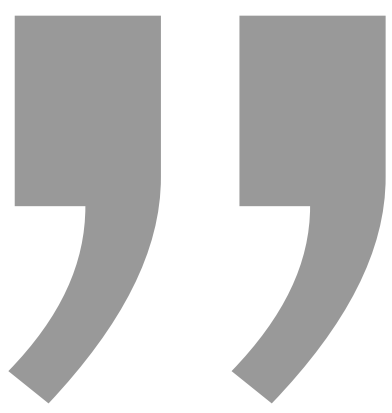

Ostatni z wymiarów komunikacji małżeńskiej deprecjacja - koreluje ujemnie jedynie z modlitwą. Wyniki te należy interpretować następująco: im częściej osoba interesuje się zagadnieniami związanymi z religia, jest bardziej przekonana o istnieniu rzeczywistości transcendentnej, częściej się modli i uczestniczy w nabożeństwach oraz czyni transcendencję elementem swoich doświadczeń, tym częściej okazuje swojemu partnerowi szacunek, docenia jego starania i angażuje się w rozwiązywanie sytuacji problemowych.

czuwając psychicznej izolacji, co w konsekwencji oznacza atmosferę bliskości, zaangażowania i zaufania. Analogicznie, na poparcie przytoczyć można także pracę Butlera, Gardnera i Birda ${ }^{66}$, którzy dowiedli, że modlitwa wzmacnia relację, podejście zorientowane na partnera, zmniejsza negatywne emocje wobec swojego partnera i nadmiernie emocjonalne sposoby reagowania (mogące przyjmować pewne formy agresji) oraz zmniejsza ryzyko przyjmowania stronniczej postawy wobec współmałżonka.

Jak wyżej wspomniano, hipoteza H4 (Częstotliwość uczestnictwa w nabożeństwach koreluje istotnie statystycznie $z$ komunikacją $w$ małżeństwie) również została częściowo potwierdzona; bowiem na poziomie istotnym statystycznie, z kultem koreluje jedynie wsparcie. Interpretacja powyższych analiz podana jest wcześniej, dlatego w tym miejscu zakreśla się jedynie ogólnie, że wraz ze wzrostem częstości i subiektywnej ważności uczestnictwa w nabożeństwach, wzrasta wsparcie w komunikacji małżeńskiej. Wyniki te korespondują z badaniami Brody’ego i współpracowników ${ }^{67}$, gdzie zaobserwowano, że częstość praktyki chodzenia do kościoła i subiektywna ważność uczestnictwa w nabożeństwach korelowała z lepszą jakością interakcji małżeńskich (zoperacjonalizowanych m.in. przez zaangażowanie i komunikację). Otrzymane wyniki można rozpatrywać w kontekście promowania przez religię zaangażowania w budowanie i rozwój relacji małżeńskiej ${ }^{68}$. Porządkując system wartości jednostki religia wyznacza określone sposoby postępowania, popularyzuje postawę

\footnotetext{
${ }^{66}$ Por. M.H. Butler, B.C. Gardner, M.H. Bird, art. cyt., s. 451-478.

${ }^{67}$ Por. G.H. Brody, Z. Stoneman, D. Flor, C. McCrary, art. cyt., s. 878-888.

${ }^{68}$ Por. K. Cieślak, art. cyt., s. 11-15.
} 
przebaczenia i miłości oraz pomaga zapobiegać konfliktom, a gdy się już pojawią, rozwiązywać je szybko i satysfakcjonująco dla obojga małżonków.

Hipoteza H5 (Wymiar centralności religijności zwany modlitwą koreluje istotnie statystycznie $w$ stopniu wyższym, niż pozostałe wymiary centralności religijności z komunikacją $w$ małżeństwie) nie została potwierdzona, bowiem korelacje istotne statystycznie między modlitwą a komunikacją małżeńską wykryto w zakresie wsparcia i deprecjacji (nie ma korelacji z zaangażowaniem). Co więcej, tylko w przypadku wsparcia związki te są silniejsze, niż przy pozostałych wymiarach centralności religijności (wynikiem ogólnym, zainteresowaniem problematyką religijną, przekonaniami religijnymi, doświadczeniem religijnym i kultem). Interpretacja tego faktu również została przedstawiona wcześniej, dlatego tutaj odnotowuje się jedynie, że wzrost częstości nawiązywania kontaktu z rzeczywistością transcendentną i przypisywanie mu subiektywnie dużego znaczenia wiąże się z silniejszym wsparciem okazywanym w komunikacji z małżonkiem oraz rzadszą deprecjacją go.

Eksploracyjnej weryfikacji poddano także analizy w podziale na grupy ze względu na płeć badanych, co przedstawiają tabele 5 i 6 . Zaobserwowano istotne statycznie dodatnie korelacje $w$ grupie kobiet pomiędzy wsparciem i wynikiem ogólnym centralności religijności, zainteresowaniem problematyką religijną, modlitwą i kultem. Zaangażowanie koreluje z kolei wyłącznie z zainteresowaniem problematyką religijną. Natomiast deprecjacja - ujemnie z modlitwą i kultem. W grupie mężczyzn nie odnotowano żadnych korelacji na poziomie istotnym statystycznie. Fakt ten można tłumaczyć różnicami międzypłciowymi w porozumiewaniu się. Tannen ${ }^{69}$ wykazała, że kobiety częściej posługują się aktywizującą formą komunikacji, angażującą rozmówcę w dyskusję. Mężczyźni z kolei, podkreślają w rozmowie swoją niezależność i autonomię. Są również mniej wrażliwi w sposobie przekazywania komunikatów - preferują oni styl bezpośredni i bardziej dyrektywny niż kobiety ${ }^{70}$. Style komunikacji są w znacznej mierze uwarunkowane kulturowo - mężczyźni często są pośrednio uczeni tego, by zachowywać się w sposób stanowczy, precyzyjny i bezpośredni, by kontrolować otoczenie i nie okazywać nadmiernie swoich uczuć ${ }^{71}$. W związku z powyższym, czynniki te mogą mieć większy wpływ na sposoby komunikowania się mężczyzn niż ich religijność.

\section{Podsumowanie}

Celem prowadzonych analiz było udzielenie odpowiedzi na główne pytanie badawcze, które brzmiało: Czy istnieją związki istotne statystycznie między centralnością religijności a komunikacją w małżeństwie? Wbadaniu odwołano się do Wielofunkcyjnego modelu religijności Stefana Hubera ${ }^{72}$ i Komunikacji małżeńskiej zaproponowanej przez Kaź-

\footnotetext{
${ }^{69}$ Zob. D. Tannen, You Just Don't Understand: Women and Men in Conversation, New York 1990.

${ }^{70}$ Zob. J.C. Pearson, Tender and Communication, Debugue, Iowa 1985.

${ }^{71}$ Por. J.D. Block, Differential Premises Arising from Differential Socialization of the Sexes: Some Conjectures, „Child Development” 1983 nr 54, s. 1335-1354.

${ }^{72}$ Por. B. Zarzycka, art. cyt., s. 231-261.
} 
mierczak i Plopę $e^{73}$. Posłużono się Skalą Centralności Religijności C-1 $15^{74}$ i Kwestionariuszem Komunikacji Małżeńskiej (KKM) ${ }^{75}$. W badaniu udział wzięło 100 osób (50 kobiet i 50 mężczyzn), będących w związkach małżeńskich.

W wyniku obróbki statystycznej danych częściowo potwierdzono hipoteza H1 (Istnieją związki istotne statystycznie między centralnym usytuowaniem religijności w poznawczej strukturze osobowości i pozytywną komunikacją w małżeństwie), ukazując związki istotne statystycznie między centralnością religijności a wsparciem i zaangażowaniem w komunikacji małżeńskiej. Nie wykryto jednak takich związków z wymiarem deprecjacji.

Częściowo potwierdzono też hipotezę H2 (Istnieją różnice istotne statystycznie w zakresie komunikacji małżeńskiej u osób o niższej i wyższej centralności religijjności). Zaobserwowano bowiem, że osoby o wysokiej centralności religijności (w porównaniu do niskiej) przejawiają większe wsparcie i zaangażowanie wobec współmałżonka.

Również częściowo potwierdzona została hipoteza H3 (Istnieją związki istotne statystycznie między wymiarami religijności a wymiarami komunikacji małżeńskiej). Związki dostrzeżono bowiem między wsparciem i wszystkimi wskaźnikami centralności religijności (ogólnym wynikiem centralności religijności, zainteresowaniem problematyką religijną, modlitwą, doświadczeniem religijnym, kultem i przekonaniami religijnymi). Korelacje zauważono także między zaangażowaniem a ogólnym wynikiem centralności religijności, zainteresowaniem problematyką religijną i doświadczeniem religijnym. Również deprecjacja korelowała, ale ujemnie i wyłącznie, z modlitwą.

Hipoteza H4 (Częstotliwość uczestnictwa w nabożeństwach koreluje istotnie statystycznie z komunikacją $w$ małżeństwie) również została częściowo potwierdzona, bowiem jak już wspomniano, na poziomie istotnym statystycznie, z kultem koreluje jedynie wymiar wsparcia w komunikacji małżeńskiej.

Ostatnia hipoteza H5 ( Wymiar centralności religijności zwany modlitwą koreluje istotnie statystycznie $w$ stopniu wyższym, niż pozostałe wymiary centralności religijności $z$ komunikacją $w$ małżeństwie) nie została potwierdzona, gdyż korelacje istotne statystycznie między modlitwą a komunikacją małżeńską zaobserwowano w zakresie wsparcia i deprecjacji (nie ma korelacji z zaangażowaniem). Co więcej, tylko w przypadku wsparcia związki te są silniejsze, niż przy pozostałych wymiarach centralności religijności (wynikiem ogólnym, zainteresowaniem problematyką religijną, przekonaniami religijnymi, doświadczeniem religijnym i kultem).

Dodatkowe korelacje - eksploracyjne, nieweryfikowane w hipotezach - odnotowano w grupie kobiet pomiędzy wsparciem i wynikiem ogólnym centralności religijności, zainteresowaniem problematyką religijną, modlitwą i kultem. Zauważono, że zaangażowanie koreluje z zainteresowaniem problematyką religijną, natomiast deprecjacja ujemnie z modlitwą i kultem. W grupie mężczyzn nie odnotowano żadnych korelacji na poziomie istotnym statystycznie.

\footnotetext{
${ }^{73}$ Zob. M. Kaźmierczak, M. Plopa, dz. cyt.

${ }^{74}$ Por. B. Zarzycka, art. cyt., s. 231-261.

${ }^{75}$ Zob. M. Kaźmierczak, M. Plopa, dz. cyt.
} 
Badani charakteryzowali się różnym wiekiem i różną długością stażu małżeńskiego. Jako dalsze perspektywy badawcze proponuje się zatem zweryfikowanie analizowanych zmiennych w określonych (węższych) grupach wiekowych lub z dokładnym zarysowaniem stażu małżeńskiego. Literatura przedmiotu wskazuje bowiem, iż komunikacja podlega różnym zmianom wraz z upływem wieku człowieka ${ }^{76}$.

\section{BIBLIOGRAFIA:}

Adamczyk, K., Inteligencja emocjonalna i system wartości małżonków a ich komunikacja interpersonalna, „Kwartalnik Naukowy” $2013 \mathrm{nr} 2$ (13), s. 72101.

Adler, R. B., Rosenfeld, L. B, Proctor, R.F, Relacje interpersonalne. Proces porozumiewania się, Poznań 2006.

Allport, G., Osobowość i religia, Warszawa 1988.

Anthony, M. J., The relationship between marital satisfaction and religious maturity, ,Religious Education” 1993 nr 88, s. 97-108.

Bartczuk, R., Jarosz, M., Funkcja Religijności w Procesie Radzenia Sobie ze Stresem Koncepcja Kennetha I. Pargamenta, „Roczniki Psychologiczne” $2006 \mathrm{nr} 9$ (1), s. 37-52.

Beit-Hallami, B., Argyle, M., The psychology of religious behaviour: Belief and experience. London 1997.

Block, J. D., Differential Premises Arising from Differential Socialization of the Sexes: Some Conjectures, „Child Development” 1983 nr 54, s. 1335-1354.

Booth, A., Johnson, D. R., Branaman, A., Sica, A., Belief and behaviour: Does religion matter in today's marriage?, „Journal of Marriage and the Family" $1995 \mathrm{nr}$ 57, s. 661-671.

Braun-Gałkowska, M., Psychospołeczne uwarunkowania powodzenia małżeństwa, „Roczniki Nauk Społecznych” 1976 nr 4, s. 209-236.

Braun-Gałkowska, M., Znaczenie religijności małżonków dla powodzenia ich związku, w: T. Kukołowicz (red.), Z badań nad rodziną, Lublin 1984, s. 57-67.

Braun-Gałkowska, M. Miłość aktywna. Psychiczne uwarunkowania powodzenia małżeństwa, Warszawa 1985.

Brody, G. H., Stoneman, Z., Flor, D., McCrary, C., Religion's Role in Organizing Family Relationship: Family Process in Rural, Two - Parent African American Families, ,Journal of Marriage and The Family” 1994 nr 56, s. 878-888.

Butler, M. H., Gardner, B. C., Bird, M. H., Not just a time-out: Change dynamics of prayer for religious couples in conflict situations, „Family Process” $1998 \mathrm{nr} 37$, s. 451-478.

\footnotetext{
${ }^{76}$ Zob. B. Harwas-Napierała, Komunikacja interpersonalna w rodzinie, Poznań 2008.
} 
Call, V. R. A., Heaton, T. B., Religious influence on marital stability, „Journal for the Scientific Study of Religion” $1997 \mathrm{nr} 36$, s. 382-392.

Cieślak, K., Religijność a sukces małżeński, „Problemy Rodziny” $1991 \mathrm{nr} 6$ (180), s. 11-15.

Dudley, M. G., Kosinski, F. A. Religiosity and marital satisfaction: A research note, „Review of Religious Research” $1990 \mathrm{nr} 32$, s. 78-86.

Frydrychowicz, S., Komunikacja interpersonalna jako wartość rozwojowa w rodzinie, w: B. Harwas-Napierała (red.), Rodzina jako wartość rozwojowa, Poznań 2009, s. 91-107.

Gapik, L., Psychologiczne problemy układów partnerskich, w: M. Kozakiewicz (red.), Wybrane zagadnienia poradnictwa małżeńskiego i rodzinnego, Warszawa 1985, s. 85-109.

Giblin, P. R., Marital spirituality: A quantitative study, „Journal of Religion and Health" $1997 \mathrm{nr} 36$, s. 321-332.

Glock, Ch. Y., Stark, R., Religion and society in tension, Chicago 1965.

Golan, Z., Pojęcie religijności, w: S. Głaz (red.), Podstawowe zagadnienia psychologii religii, Kraków 2006, s. 71-79.

Harwas-Napierała, B., Komunikacja interpersonalna w rodzinie, Poznań 2008.

Heaton, T. B., Pratt, E. L., The effects of religious homogamy on marital satisfaction and stability, ,Journal of Family Issues” 1990 nr 11, s. 191207.

Hünler, O. S., Gencoz, T., The effect of religiousness on marital satisfaction: testing the mediator role of marital problem solving between religiousness and marital satisfaction relationship, „Contemporary Family Therapy” $2005 \mathrm{nr} 27$ (1), s. 123-136.

Jaworski, R., Psychologiczne korelaty religijności personalnej, Lublin 1989.

Kaźmierczak, M., Plopa, M., Kwestionariusz Komunikacji Małżeńskiej. Podręcznik, Warszawa 2008.

Kelly, G., The psychology of personal constructs, New York 1955.

Khodabakhshi, A., Hossein-Abadi, F. H., Religiosity, Marital Satisfaction and Child Rearing; ,Pastoral Psychology” 2009 nr 57, s. 211-221.

Khodabakhshi, A., Azad-Marzabadi, E., Ashrafi S. M. N., The Influence of Religiosity on Marital Satisfaction, ,Journal of Social Sciences” $2008 \mathrm{nr} 4$ (2), s. 128-135.

Krok, D., Religijność a jakość życia w perspektywie mediatorów psychospołecznych, Opole 2009.

Kupczyk, J. Ideał przyszłego małżonka w oczach młodzieży, „Ruch Pedagogiczny" $1974 \mathrm{nr} 6$, s. 829.

Mahoney, A., Pargament, K. I., Jewell, T., Swank, A. B., Scott, E., Emery, E., Rye, M., Marriage and the spiritual realm - the role of proximal and distal religious constructs in marital functioning, ,Journal of Family Psychology" 1999 nr 13, s. 321-338. 
Michałek, J. Rola cech osobowości partnerów w kształtowaniu jakości związku małżeńskiego, niepublikowana praca magisterska napisana pod kierunkiem M. Kaźmierczak, Gdańsk 2008.

Pearson, J. C., Tender and Communication, Debugue, Iowa 1985.

Plopa M., Psychologia rodziny. Teoria i badania, Elbląg 2004.

Rostowski, J., Zarys psychologii małżeństwa. Psychologiczne uwarunkowania dobranego związku małżeńskiego, Warszawa 1987.

Rostowska, T., Żylińska, P., Stopień zaangażowania religijnego a poziom jakości małżeńskiej partnerów, w: T. Rostowska (red.), Psychologia rodziny. Małżeństwo i rodzina wobec wspólczesnych wyzwań, Warszawa 2009, s. 117-135.

Ryś, M., Psychologia malżeństwa. Zarys problematyki, Warszawa 1993.

Ryś, M., Systemy rodzinne. Metody badań struktury rodziny pochodzenia i rodziny własnej, Warszawa 2008.

Shehan, C. L., Bock, E. W., Lee, G. R., Religious heterogamy, religiosity and marital happiness: The case of Catholics, „Journal of Marriage and the Family" 1990 nr 52, s. 73-79.

Stark, R., Glock, Ch. Y., American Piety: The nature of religious commitment, Berkeley, Los Angeles, London 1970.

Śliwak, J., Altruizm a religijność. Przegląd badań, w: Wykłady z psychologii W KUL, Lublin 1989, s. 187-198.

Śliwak, J., Altruizm a religijność człowieka - badania empiryczne, „Roczniki Filozoficzne" $1993 \mathrm{nr}$ 4, s. 41-52.

Tannen, D., You Just Don't Understand: Women and Men in Conversation, New York 1990.

Tracewicz, E., Nieodwołalność decyzji zawarcia związku małżeńskiego w ocenie osób rozwiedzionych, „Zeszyty Naukowe KUL” $1981 \mathrm{nr}$ 204, s. 81-104.

Walesa, C., Rozwój zgodności religijnych przekonań i praktyk współmałżonków oraz jej związki z zadowoleniem z małżeństwa, „Roczniki Filozoficzne" $1978 \mathrm{nr} 4$, s. 91-113.

Wilson, M. R., Filsinger, E. E., Religiosity and marital adjustment: Multidimensional interrelationship, ,Journal of Marriage and the Family" $1986 \mathrm{nr}$ 48, s. 147-151.

Zarzycka, B., Polska adaptacja Skali Centralności Religijności S. Hubera, w: M. Jarosz (red.), Psychologiczny pomiar religijności, Lublin 2011, s. 231-261.

\section{WYKAZ SKRÓTÓW:}

dz. cyt. - dzieło cytowane

art. cyt. - artykuł cytowany

cyt. za: - cytat za:

por. - porównaj

zob. - zobacz 


\section{DIALOG RELIGII I KULTURY}

\section{O AUTORACH:}

Jacek Sliwak - doktor habilitowany nauk humanistycznych, profesor Katolickiego Uniwersytetu Lubelskiego, kierownik Katedry Psychologii Społecznej i Psychologii Religii w Instytucie Psychologii. Promotor 4 doktoratów i 250 prac magisterskich. W latach 2001 - 2008 kierownik Międzywydziałowego Podyplomowego Studium Rodziny przy KUL. Zainteresowania badawcze: altruizm, relacje interpersonalne, zachowania asertywne, postawy religijne, relacje religijne, poznawcze korelaty religijności.

Beata Zarzycka - doktor nauk humanistycznych w zakresie psychologii, adiunkt w Katedrze Psychologii Społecznej i Psychologii Religii w Instytucie Psychologii Katolickiego Uniwersytetu Lubelskiego, kierownik podyplomowych studiów $W$ zakresie poradnictwa psychologicznego i psychoterapii dla duchowieństwa w KUL. Zainteresowania badawcze: struktura i rozwój religijności, poznawcze korelaty religijności, związki religijności ze zdrowiem psychicznym, metodologia psychologii religii.

Dominika Zarosińska - doktorantka psychologii w Katedrze Psychologii Społecznej i Psychologii Religii KUL, absolwentka Nauk o Rodzinie KUL. Wyróżniana w Konkursie na Najlepszego Studenta RP „Studencki Nobel” w latach 2012-2015. Współorganizator licznych konferencji i sympozjów naukowych, popularyzator nauki w ramach Lubelskiego Festiwalu Nauki w latach 2012-2016, prelegentka podczas licznych sesji na konferencjach o zasięgu ogólnopolskim i międzynarodowym, autorka i współautorka artykułów naukowych.

Urszula Piaszczak - absolwentka Psychologii KUL, magister.

Kontakt: Katedra Psychologii Społecznej i Psychologii Religii

Instytut Psychologii Katolickiego Uniwersytetu Lubelskiego Jana Pawła II

Aleje Racławickie 14

20-950 Lublin 